\title{
Flourishing in subterranean ecosystems: Euro-Mediterranean Plusiocampinae and tachycampoids (Diplura, Campodeidae)
}

\begin{abstract}
Alberto SENDRA ${ }^{1, *}$, Dragan ANTIĆ ${ }^{2}$, Pablo BARRANCO $^{3}$, Špela BORKO ${ }^{4}$, Erhard CHRISTIAN ${ }^{5}$, Teo DELIĆ ${ }^{6}$, Floren FADRIQUE ${ }^{7}$, Arnaud FAILLE ${ }^{8}$, Loris GALLI ${ }^{9}$, Fulvio GASPARO ${ }^{10}$, Dilian GEORGIEV ${ }^{11}$, Pier Mauro GIACHINO ${ }^{12}$, L'ubomír KOVÁČ ${ }^{13}$, Marko LUKIĆ ${ }^{14}$, Paolo MARCIA ${ }^{15}$, Kazimir MICULINIĆ ${ }^{16}$, Giuseppe NICOLOSI ${ }^{17}$, Ferran PALERO ${ }^{18}$, Kaloust PARAGAMIAN ${ }^{19}$, Toni PÉREZ ${ }^{20}$, Slavko POLAK ${ }^{21}$, Carlos E.
\end{abstract} PRIETO $^{22}$, Ilya TURBANOV ${ }^{23}$, Dante VAILATI ${ }^{24} \&$ Ana Sofia P.S. REBOLEIRA ${ }^{25}$

${ }^{1}$ Research Team on Soil Biology and Subterranean Ecosystems, Department of Life Sciences, Faculty of Biology, Chemistry and Environmental Sciences, University of Alcalá (UAH),

A.P. 20, Campus Universitario, 28805 Alcalá de Henares, Madrid, Spain.

${ }^{1}$ Colecciones Entomológicas Torres-Sala, Servei de Patrimoni Històric,

Ajuntament de València, 46230 València, Spain.

${ }^{2}$ University of Belgrade, Faculty of Biology, Institute of Zoology,

Studentski trg 16, 11000 Belgrade, Serbia.

${ }^{3}$ Department of Biology and Geology, University of Almería, 04120 Almería, Spain.

${ }^{4,6}$ SubBio Lab, Department of Biology, Biotechnical Faculty, University of Ljubljana, Večna pot 111, 1000 Ljubljana, Slovenia.

${ }^{5}$ Institute of Zoology, University of Natural Resources and Life Sciences, Gregor Mendel Str. 33, 1180 Vienna, Austria.

${ }^{7}$ Associació Catalana de Biospeleologia (BIOSP), C/Moreres 3, l'Hospitalet de l'Infant, 43890 Tarragona, Spain.

${ }^{8}$ Stuttgart State Museum of Natural History, Rosenstein 1, 70191 Stuttgart, Germany.

${ }^{9}$ Department of Earth, Environment and Life Sciences, University of Genova, Corso Europa 26, 16132 Genova, Italy.

${ }^{10}$ Commissione Grotte "E. Boegan", Società Alpina delle Giulie, C.A.I., Via Donota 2, 34121 Trieste, Italy.

${ }^{11}$ Department of Ecology and Environmental Conservation, University of Plovdiv, Tzar Assen Str. 24, 4000 Plovdiv, Bulgaria.

${ }^{12}$ Settore Fitosanitario Regionale, Environment Park, Palazzina A2, via Livorno 60, 10144 Torino, Italy.

${ }^{13}$ Department of Zoology, Institute of Biology and Ecology, Faculty of Science,

P.J. Šafárik University, Šrobárova 2, 04180 Košice, Slovakia.

${ }^{14,16}$ Croatian Biospeleological Society, Demetrova 1, 10000 Zagreb, Croatia.

${ }^{15}$ Department of Veterinary Medicine, University of Sassari, 07100 Sassari, Sardinia, Italy.

${ }^{17}$ Department of Life Sciences and Systems Biology, University of Turin,

Via Accademia Albertina 13, 10123 Torino, Italy.

${ }^{18}$ Department of Invertebrate Zoology and Hydrobiology, Faculty of Biology and Environmental

Protection, University of Łódź, ul. Banacha 12/16, 90-237 Łódź, Poland.

${ }^{18}$ Department of Life Sciences, The Natural History Museum, Cromwell Road, London SW7 5BD, UK. 
${ }^{18}$ Centre d'Estudis Avançats de Blanes (CEAB-CSIC),

Carrer d'accés a la Cala Sant Francesc 14, 17300 Blanes, Spain.

${ }^{19}$ Hellenic Institute of Speleological Research, Ethnikis Antistaseos 82,

71306 Irakleion, Crete, Greece.

${ }^{20}$ Grupo de Espeleología de Villacarrillo, Plaza 28 de Febrero, $\mathrm{n}^{\circ} 5$, $1^{\mathrm{o}-} 2^{\mathrm{a}}, 23300$ Villacarrillo (Jaén), Spain.

${ }^{21}$ Notranjska Museum Postojna, Kolodvorska c. 3, 6230 Postojna, Slovenia.

${ }^{22}$ Departamento de Zoología y Biología Celular Animal, University of the Basque Country, P.O. Box 644, 48080 Bilbao, Spain.

${ }^{23}$ Institute of the Biology of Inland Waters, Russian Academy of Sciences,

Borok, Yaroslavl Region, 1527432 Russia.

${ }^{23}$ Cherepovets State University, Cherepovets, Vologda Region, 162600 Russia.

${ }^{24}$ Via Interna 8, 25127 Brescia, Italy.

${ }^{25}$ Natural History Museum of Denmark, University of Copenhagen,

Universitetsparken 15, 2100 Copenhagen Ø, Denmark.

*Corresponding author: alberto.sendra@uv.es

${ }^{2}$ Email: dragan.antic@bio.bg.ac.rs

${ }^{3}$ Email: Pablo.Barranco@ual.es

${ }^{4}$ Email: borko.spela@gmail.com

${ }^{5}$ Email: erhard.christian@boku.ac.at

6Email: Teo.Delic@bf.uni-lj.si

${ }^{7}$ Email: ffadrique@hotmail.com

${ }^{8}$ Email: arnaud.faille@mnhn.fr

${ }^{9}$ Email: loris.galli@unige.it

${ }^{10}$ Email: fulvio.gasparo@libero.it

${ }^{11}$ Email: diliangeorgiev@abv.bg

${ }^{12}$ Email: PierMauro.Giachino@regione.piemonte.it

${ }^{13}$ Email: lubomir.kovac@upjs.sk

${ }^{14}$ Email: marko.lukic@hbsd.hr

${ }^{15}$ Email: pmarcia@uniss.it

${ }^{16}$ Email: miculinic@yahoo.com

${ }^{17}$ Email: gnicolosi@hotmail.it

${ }^{18}$ Email: fpalero@gmail.com

${ }^{19}$ Email: k.paragamian@wwf.gr

${ }^{20}$ Email: bioespeleologiaGEV@gmail.com

${ }^{21}$ Email: slavko.polak@guest.arnes.si

${ }^{22}$ Email: ggpprsic@lg.ehu.es

${ }^{23}$ Email: turba13@mail.ru

${ }^{24}$ Email: dante.vailati@libero.it

${ }^{25}$ Email: sreboleira@snm.ku.dk

\footnotetext{
${ }^{1}$ urn:1sid:zoobank.org:author:A39300D8-0D4F-426D-8138-FE72D5700B83

${ }^{2}$ urn:1sid:zoobank.org:author:A3774DC0-0710-4F91-8F36-F18620D694E0

${ }^{3}$ urn:lsid:zoobank.org:author:060BC3CC-A1A7-4BC2-A408-22077A125EED

${ }^{4}$ urn:lsid:zoobank.org:author:743B3331-4D63-4FB4-A5A1-5E876445E6F6

${ }^{5}$ urn:Isid:zoobank.org:author:AD4A7348-B28F-44AD-BDA0-FB04E969F5B9

${ }^{6}$ urn:lsid:zoobank.org:author:D38183EA-6034-4634-8DD1-45FF9C73D2B4

${ }^{7}$ urn:1sid:zoobank.org:author:90C2A5C4-A7ED-4DCA-8207-4692B7B81078

${ }^{8}$ urn:1sid:zoobank.org:author:34F015D0-0840-478A-BFE2-AA2B1F6D05D5
} 
SENDRA A. et al., Euro-Mediterranean Plusiocampinae and tachycampoid diplurans

\footnotetext{
${ }^{9}$ urn:1sid:zoobank.org:author:976A4615-5713-461B-B48B-7658D7125276

${ }^{10}$ urn:lsid:zoobank.org:author:F65C1400-2AEA-42BE-8886-0A4B6C6789B0

${ }^{11}$ urn:Isid:zoobank.org:author:B9816B63-8496-4EA6-81C0-4DB62EA331DA

${ }^{12}$ urn:lsid:zoobank.org:author:3EB353B6-3A14-4906-9805-BDD79D457E71

${ }^{13}$ urn:lsid:zoobank.org:author:64C6117E-DB5C-4569-BF89-5C812C118760

${ }^{14}$ urn:1sid:zoobank.org:author:6B455B4B-F0E4-4545-99C0-1CC87BD81327

${ }^{15}$ urn:lsid:zoobank.org:author:505E7088-28A6-46BA-88BD-9343C99BC36E

${ }^{16}$ urn:1sid:zoobank.org:author:DD0FC3F4-8D9C-481E-B292-BB180DD1CA20

${ }^{17}$ urn:lsid:zoobank.org:author:FEF08BB9-468B-4C02-A757-84B5EDDA6BAA

${ }^{18}$ urn:1sid:zoobank.org:author:6FDDFE46-501A-4D6E-975E-72F55617775C

${ }^{19}$ urn:lsid:zoobank.org:author:10B3AD4F-1AF6-4111-80B8-043D4EE675EE

${ }^{20}$ urn:1sid:zoobank.org:author:9CB76198-1B76-4D5B-9578-5EF6F1B68E51

${ }^{21}$ urn:1sid:zoobank.org:author:1E119F76-B3F0-4E37-BB3F-9216AFB5CD88

${ }^{22}$ urn:1sid:zoobank.org:author:CAC20D21-78FF-4B8A-8023-F06A06EA031F

${ }^{23}$ urn:lsid:zoobank.org:author:E8F01940-9A2B-4153-9106-A6AF2A79D0A1

${ }^{24}$ urn:1sid:zoobank.org:author:6D052C67-2975-4BD1-B7F2-B537F21FE625

${ }^{25}$ urn:1sid:zoobank.org:author:338DE845-4839-4EF5-B684-587C021F076C
}

\begin{abstract}
Diplura is a group of entognathous hexapods, often considered a sister group to insects. They play an important role in recycling organic matter in soil and subterranean terrestrial ecosystems. The Campodeidae is the most diverse family, divided into four subfamilies. The subfamily Plusiocampinae has a subterranean life-style with many species distributed in the Euro-Mediterranean area. The incertae sedis tachycampoids ("lignée Tachycampoïde") is a group within the family Campodeidae that share with the Plusiocampinae a strong preference for subterranean habitats and several morphological characters, such as slender body shape, elongated appendages, considerable increment in the number of antennomeres and cercal articles, and complexity of sensorial structures. The present monograph provides a taxonomic revision of the subfamily Plusiocampinae and the genera belonging to the tachycampoid lineage from Europe and the Mediterranean region. It comprises detailed morphological descriptions and illustrations together with data on the habitats and distributions of 87 species, 10 subspecies and 11 affinis forms. Seven new species are described among those, namely: Plusiocampa (Plusiocampa) apollo Sendra, Giachino \& Vailati sp. nov., $P$. (P.) chiosensis Sendra \& Gasparo sp. nov., $P$. (P.) dublanskii Sendra \& Turbanov sp. nov., $P$. (P.) hoffmanni Sendra \& Paragamian sp. nov., $P$. (P.) rhea Sendra sp. nov., $P$. (P.) ternovensis Sendra \& Borko sp. nov. and $P$. (Venetocampa) ferrani Sendra \& Delić sp. nov.
\end{abstract}

Keywords. Dipluran, cave fauna, troglobite, Europe, circum-Mediterranean.

Sendra A., Antić D., Barranco P., Borko Š., Christian E., Delić T., Fadrique F., Faille A., Galli L., Gasparo F., Georgiev D., Giachino P.M., Kováć L., Lukić M., Marcia P., Miculinić K., Nicolosi G., Palero F., Paragamian K., Pérez T., Polak S., Prieto C.E., Turbanov I., Vailati D. \& Reboleira A.S.P.S. 2020. Flourishing in subterranean ecosystems: Euro-Mediterranean Plusiocampinae and tachycampoids (Diplura, Campodeidae). European Journal of Taxonomy 591: 1-138. https://doi.org/10.5852/ejt.2020.591

\title{
Introduction
}

Diplura is a group of eyeless entognathous hexapods, often considered a sister group to insects, which colonize terrestrial habitats, presenting a tracheal system, rudimentary Malpighian tubules and sperm transfer via a spermatophore (Beutel et al. 2017; Denis 1949). About 1000 extant dipluran species are named and described in 10 dipluran families. Half of this diversity belongs to the Campodeidae (Condé 1955a; Pagés 1959; Sendra 2015). The family Campodeidae is characterized by soft pluriarticular cerci 
without glands and is divided into four subfamilies: Campodeinae Condé, 1956, Lepidocampinae Condé, 1956, Hemicampinae Condé, 1956 and Plusiocampinae Paclt, 1957.

Campodeids live in terrestrial habitats from soil to subterranean ecosystems, where they are active decomposers of decaying organic matter, opportunistic scavengers or spore feeders (Christian \& Bauer 2007). Within campodeids, the subfamily Campodeinae is the most diverse, distributed worldwide (Condé 1955a), while Lepidocampinae and Hemicampinae are restricted to tropical regions. Unlike Hemicampinae, both Campodeinae and Lepidocampinae have species distributed in subterranean ecosystems, mainly in the campodeine genera Litocampa Silvestri, 1933 and Podocampa Silvestri, 1932 (Condé 1955a). Nonetheless, the subfamily Plusiocampinae is the most diverse in subterranean habitats, with over 50 species described from the Euro-Mediterranean region. Only 10 species of Plusiocampinae, belonging to five genera, are found beyond the Euro-Mediterranean region (Holarctic realm) and throughout the Indomalayan and possibly the Afrotropical realms (Condé 1955a; Paclt 1957; Sendra et al. 2016, 2017a).

In addition, some other genera with an uncertain position among the different subfamilies of Campodeidae are referred to under the informal term coined by Bareth \& Condé (1981) as the "lignée Tachycampoïde," which is named the tachycampoid lineage in this text. This lineage currently contains five genera and 17 species, and it has a disjunct distribution on both sides of the Atlantic Ocean, in Mexico, Guatemala and eastern Brazil and in the western Euro-Mediterranean region (Sendra et al. 2016). Plusiocampinae and tachycampoids share a strong preference for subterranean habitats and several common morphological characters: slender body shape, elongate appendages, a considerable increment in the number of antennomeres and cercal articles, and numerous and complex sensorial structures.

Historically, campodeids have been placed in a single genus, Campodea Westwood, 1842, including species from European caves (Joseph 1882; Viré 1897). Plusiocampa Silvestri, 1912 was established based on their elevated number of macrosetae and the lateral crests on their claws. Subsequently, some of the former Campodea were transferred into the Plusiocampinae (Denis 1923; Condé 1955a), and many species were described, especially in the genus Plusiocampa. All species of Plusiocampinae are characterized by their pattern of pronotal macrosetae, with more than $3+3$ macrosetae (Paclt 1957).

Five subgenera of Plusiocampa occur in the Euro-Mediterranean region: Plusiocampa s. str. from the Mediterranean basin and the Alps; Stygiocampa Silvestri, 1934, endemic to the subterranean environment of the Dinaric Mountains and part of the Balkan System; the controversial subgenus Dydimocampa Paclt, 1957, extending from Crimea to the Iberian Peninsula; Venetocampa Bareth \& Condé, 1984, in the Italian and Slovenian Alps; and Pentachaetocampa Sendra \& Weber, 2018, only known from a cave in the Black Forest, Germany.

Four other genera closely related to Plusiocampa occur in the Euro-Mediterranean region: Cestocampa Condé, 1956, Hystrichocampa Condé, 1948, Patrizicampa Condé, 1956 and Vandelicampa Condé, 1956. Six genera of Plusiocampinae are distributed outside the Euro-Mediterranean region: Anisuracampa Xie \& Yang, 1991 in China; Silvestricampa Condé, 1950 in South Africa; Simlacampa Condé, 1956 in caves of the Indian Himalayas; Plutocampa Chevrizov, 1978, with two species in northeastern Asia; Condeicampa Ferguson, 1996; and the recently described Turkmenocampa Sendra \& Stoev, 2017 from a single cave in Central Asia. In addition to these, we plan to describe new genera, mostly from Southeast Asia, in the near future.

The first species described in the tachycampoid lineage was Tachycampa lepineyi Silvestri, 1936, collected in a cave in the western Rif Mountains, northwest Africa. The phyletic group also comprises Paratachycampa Wygodzinsky, 1944, Juxtlacampa Wygodzinsky, 1944, Jeannelicampa Condé, 1952 and Oncinocampa Condé, 1982. Recently, new tachycampoid species have been described on both 
sides of the Atlantic and the nine American and eight Euro-Mediterranean species clearly indicate a disjunct distribution of the group. Some species of Oncinocampa, Paratachycampa and Tachycampa show amphi-Atlantic distributions (Bareth \& Condé 1981; Sendra et al. 2016).

A taxonomic revision of most plusiocampine and tachycampoid genera from the Euro-Mediterranean region is provided (see complete list of previously published reports in Table S1 in Supplementary Material), together with the description of seven new species. The present monograph also provides detailed descriptions and illustrations of the morphological characters, as well as data on habitats and distribution maps, based on material from several collections and freshly sampled specimens.

\section{Material and methods}

During the last decade, an enthusiastic group of friends and colleagues, speleologists, biospeleologists and biologists have gathered many samples of Plusiocampinae and tachycampoids. This material was sampled in soil and hypogean habitats, including the deepest dipluran ever collected at $1180 \mathrm{~m}$ below the surface of the Kanin Mountains, in Slovenia. This large sampling effort extended over the EuroMediterranean region, including many Mediterranean islands. It resulted in a total of 4243 specimens from 182 localities, most of them in carbonate caves. Details on the specimens collected for each species are given in the 'Habitat and distribution' sections, including all localities of the Euro-Mediterranean species. A complete list of collecting events, organized by taxon, is presented in Table S2 in the Supplementary Material.

Specimens were washed using distilled water, mounted on slides in Marc André II solution and studied under a phase-contrast microscope (Leica DMLS). The illustrations were made using a drawing tube. Measurements were taken with an ocular micrometer. The specimens mounted 'in toto' were measured from the distal macrosetae on the frontal process to the abdominal supra-anal valve. For scanning electron microscopy (SEM) some specimens were critical point-dried, coated with palladium-gold and studied under a Hitachi S-4100 SEM.

The identification keys to genera, subgenera and species of Plusiocampinae and tachycampoids were generated from a DELTA database (Dallwitz 2005) and modified to improve readability. For each taxon, a diagnosis has been generated, as well as a habitat and distribution section. Taxonomic notes and character illustrations are provided for the seven newly described species.

For indications of ecological context used in the text we have applied the following definitions (Racovitză 1907; Juberthie \& Decu 1994; Giachino \& Vailati 2010; Ortuño et al. 2013; Moldovan et al. 2018):

- Hypogean habitats: refers to those found below the surface, as opposed to those above the surface (epigean habitats). Hypogean habitats are always aphotic with less influence from the surface.

- Edaphic habitats: superficial hypogean habitats that extend through the spaces in the soil (A and B horizons) where the edaphic fauna or soil-dwelling fauna live.

- Endogean fauna: animals living in the B horizon of soils, where smaller voids occur.

- Subterranean habitats: deep hypogean habitats extending through a network of spaces (caves) developed in the bedrock, where subterranean or cave-dwelling fauna live.

- Mesovoid Shallow Substratum (MSS): terrestrial habitats in the interstitial mid-size voids below the soil or directly under the surface in colluvial or alluvial environments, inhabited by soil and subterranean fauna and MSS specialized fauna.

Troglobites are cave-adapted fauna living permanently in subterranean habitats, exhibiting similar convergent evolutionary traits (troglomorphisms) such as unpigmented and elongated bodies and appendages, as well as hypertrophy of sensorial organs. 
A complete database including the localities where each species has been found was built using our own observations and locality data from an intensive literature review. Locality names and addresses were used to obtain the corresponding GPS coordinates from Google maps using the Import[] function implemented in the Mathematica ver. 11.0 software package (Wolfram Inc., USA). Coordinates obtained from the locality names cited in the literature do not correspond to the exact collecting spot (e.g., cave entrance) in most cases, but rather to the closest town to the sampling site. Distribution maps were built for Plusiocampinae and tachycampoids, genera, subgenera or morphogroups using the GeoListPlot[] function in Mathematica.

The type and studied material is kept at the following institutions:

Coll. AS = private collection of Alberto Sendra, València, Spain

MZB = Museu de Zoologia de Barcelona, Spain

PMSL = Slovenian Museum of Natural History, Ljubljana, Slovenia

ZMMU = Zoological Museum of Moscow University, Moscow, Russia

Other specimens mentioned in Table S2 in Supplementary Material have been used for taxon identification.

\section{Results}

\section{Taxonomic characters in Plusiocampinae and tachycampoid genera}

The 10 extant dipluran families differ clearly in morphology, but uniformity prevails within the families and lower taxa. This applies also to Campodeidae and to the subordinate Plusiocampinae and tachycampoids. Interspecific differences in these groups are based mainly on the position of the mechanoreceptor setae (in particular the macrosetae that have a fixed place of insertion), the shape of the pretarsus, including the claws and its outer lateral processes, and the secondary sexual characters of the first urosternite.

\section{General characters}

\section{Integument}

The cuticle is thin and most species show a smooth epicuticle under the optical microscope, but a reticulate structure is frequently visible using SEM. The surface of the cuticle has microdenticles in a few taxa (e.g., Tachycampa; Sendra et al. 2016).

Relevant taxonomic characters are the mechanoreceptor setae and other sensorial structures (Condé 1955a; Bareth 1968). The macrosetae, large setae with a discernible base in an upright position, improve the mechanoreceptor function. Macrosetae occupy a fixed position on the body during post-embryonic development (Orelli 1956). They are longer and thicker than ordinary setae, and they have larger bases and usually more barbs. Exceptionally, in very few species macrosetae are substituted by submacrosetae, which are thinner, shorter and less barbed than the typical macrosetae. Apart from macrosetae on appendages, three main macrosetal formulas along the body are also used to characterize most genera and species: the notal, the urotergal and the urosternal formulas (Condé 1955a; Paclt 1957).

Notal macrosetal formula. Macrosetae can occupy six main positions on each notum: $m a=$ medial anterior; $l a=$ lateral anterior; $l p=$ lateral posterior; $m p=$ medial posterior; $m i=$ medial intermediate; and $l i=$ lateral intermediate. In the groups under consideration here, the pronotum never has less than 4+4 ma, la, $l p_{2,3}\left(m a, l a_{1,4} l p_{3}\right.$ in Plusiocampa (Stygiocampa) christiani Condé \& Bareth, 1996); the mesonotum and metanotum can bear from zero to an astonishingly high number of macrosetae. The South African Silvestricampa lawrencei Condé, 1949, for instance, has 10+10 ( $\left.m a, l a a_{1-3}, m i, l i, l p_{1-4}\right)$ and 6+6 ( $m a, m i$, $\left.l i, l p_{l-3}\right)$. In tachycampoids the notal formula is consistently $3+3(m a, l a, l p), 2+2(m a, l a)$ and $1+1(m a)$. 
Urotergal macrosetal formula. Macrosetae can occupy two different positions on each urotergite: post, posterior and $l a$, lateral anterior. Three regions can be distinguished: (1) anterior urotergites with $0+0$ to $3+3$ post and without la macrosetae; (2) medial urotergites with up to $6+6$ post and up to $3+3$ la macrosetae; and (3) urotergite VIII and adominal segment IX with up to $10+10$ post macrosetae and without la macrosetae.

Urosternites usually have short, well-barbed macrosetae. Three urosternal regions can be distinguished: (1) urosternite I frequently with $7+7-8+8$ to numerous extra macrosetae (up to about sixty in total); (2) urosternites II-VII with $5+5$ up to $14+14$ macrosetae; and (3) urosternite VIII with $1+1$ to up to $4+4$ macrosetae.

Macrosetae on appendages. The most relevant characters to differentiate species and subgenera are the number of dorsal femoral macrosetae, from 0 to 5 ; the number of short ventral tibial macrosetae, from 0 to 4 ; and the long or short, more or less barbed cercal macrosetae.

Stylus setae and the calcars on the tibiae show differences in the degree of barbulation and may also be used in taxonomy, together with the eversible vesicles observed under the SEM.

Sensillum of the third antennomere. One (exceptionally three) isolated subcylindrical to spheroidal sensillum can occupy two main positions (dorsal and ventral) among the crown of macrosetae, which encircle the third antennomere. To determine the position of this sensory organ, the macrosetae are named as $a$ macrosetae between the two trichobothria, as $b$ macrosetae when situated on the exterior side, and as $c, d$ and $e$ when they continue on up to the crown macrosetae (Condé 1955a).

Cupuliform organ. This sensory organ is an invagination of the integument at the end of the apical antennomere crammed with olfactory chemoreceptors (Juberthie-Jupeau \& Bareth 1980). These increase in number and shape complexity in subterranean species, reaching a remarkable diversity (Sendra et al. 2017a).

Gouge sensilla (Bareth \& Condé 1981). These are situated in an apical whorl on medial and distal antennomeres and show a slight variability of forms. Nevertheless, their taxonomical value has not yet been explored.

\section{Pretarsus}

The shape of the distal structure of the tarsus, with two claws and usually each with an outer lateral process, has been used to define genera. The main claw types are: (1) the more frequent, elbow-like claws, with lateral crests; (2) less frequent, subequal smooth claws, regularly curved without lateral crests, found in Silvestricampa and Jeannelicampa; and (3) elbow-like claws with a sharp side-shoot, as in Turkmenocampa. The lateral processes are also taken into account for generic delimitation; they vary from setiform to laminar and with or without short to long pubescence or dense barbs.

\section{Sexual characters}

Secondary sex characteristics are present on the first urosternite: the shape of the posterior border and appendages, and the number and type of glandular setae. A complete area of glandular $g_{1}$ setae along the posterior border is frequently present in males and exceptionally in females (Sendra \& Weber 2018). The appendages of the first urosternite are generally subcylindrical in females, while they are enlarged in males. Both sexes have glandular $a_{1}$ setae, and glandular $a_{2}$ setae can be present in males and less frequently in females.

Spermatozoid fascicles, a packed group of spermatozoons in a spiral structure, are produced by a pair of testicles located in the abdomen of the male. These spirals can vary in length, size and shape, but are usually short and thick in Plusiocampinae (Bareth 1968). 
Taxonomy of Plusiocampinae Paclt, 1957

Class Diplura Börner, 1904

Family Campodeidae Meinert, 1865

Subfamily Plusiocampinae Paclt, 1957

Plusiocampinae Paclt, 1957: 42.

Diagnosis (Condé 1955a; Paclt 1957; Sendra et al. 2017a)

Since the only diagnostic character of Plusiocampinae (as suggested by Paclt 1957) is the higher number of macrosetae on the pronotum, this taxon seems to be paraphyletic. The pronotum never has less than 4+4 macrosetae. However, many of the genera can be considered monophyletic within Plusiocampinae. This is the case for Anisuracampa, Cestocampa, Condeicampa, Hystrichocampa, Patrizicampa, Plusiocampa, Plutocampa, Simlacampa and Vandelicampa, characterized by pretarsal lateral crests. Nonetheless, these lateral crests are absent in Silvestricampa and Turkmenocampa, clearly isolating them from the other genera.

\section{Key to the genera of Plusiocampinae}

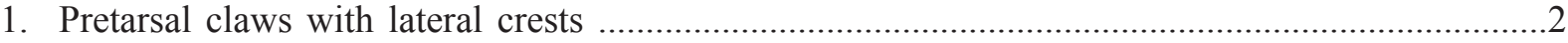

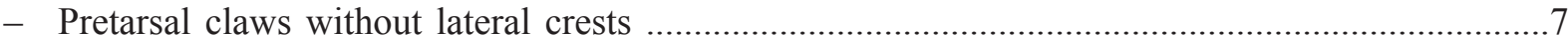

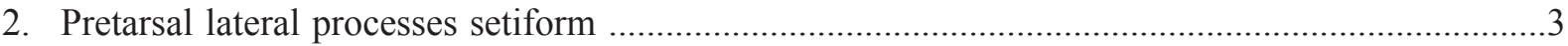

- Pretarsal lateral processes laminar barbed or absent ...................................................................

3. Pretarsal lateral processes pubescent ...............................................Hystrichocampa Condé, 1948

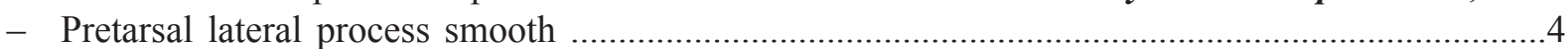

4. 4+4 macrosetae on urosternites II-VII, 1+1 macrosetae on urosternite VIII

Condeicampa Ferguson, 1996 and Plusiocampa (Dydimocampa) sinensis Silvestri, 1931

- No less than 5+5 macrosetae on urosternites II-VII and 2+2 macrosetae on urosternite VIII

Plusiocampa Silvestri, 1912

5. Pretarsal lateral processes absent

Plutocampa Chevrizov, 1978

- Pretarsal lateral processes laminar barbed

6. Pretarsal lateral processes laminar

Cestocampa Condé, 1955, Vandelicampa Condé, 1955, Patrizicampa Condé, 1956, Anisuracampa Xie \& Yang, 1991, Plusiocampa (Didymocampa) lipsae Condé, 1993 and Plusiocampa kashiensis (Chou \& Tong, 1980)

- Pretarsal lateral processes narrow Simlacampa Condé, 1956

7. Simple claws; pretarsal lateral processes absent, medial-intermediate and lateral-intermediate macrosetae on mesonotum and metanotum Silvestricampa Condé, 1950

- Pretarsal claws with sharp side-shoot; pretarsal lateral processes laminar, without medial posterior macrosetae on mesonotum and metanotum Turkmenocampa Sendra \& Stoev, 2017

This key includes 11 accepted genera plus three species, Plusiocampa (Dydimocampa) sinensis, Plusiocampa (Dydimocampa) lipsae and Plusiocampa kashiensis from China, which remain in an uncertain position (Sendra et al. 2012a). Three new troglomorphic genera from China, Indochina and the Aegean islands, which are currently under description (Sendra, in prep.), are excluded. 
Cestocampa Condé, 1955a: 132.

Diagnosis (Condé 1955a; Sendra et al. 2012a)

Non-protruding frontal process with non-tubercular setae. Mesonotum with $1+1$ medial anterior, $3+3$ lateral anterior and $2+2$ lateral posterior macrosetae; metanotum with $1+1$ medial anterior, $2+2$ lateral anterior and $2+2$ lateral posterior macrosetae. With or without medial posterior notal macrosetae. One dorsal femoral macroseta. Two to three ventral tibial macrosetae. Subequal elbow-like claws, posterior claw equal (1.0) to subequal (1.1) to anterior claw. Laminar pretarsal lateral processes with long, rigid, ventral hook-tipped barbs. Urotergites I-II with $1+1-2+2$ posterior macrosetae; urotergite III with $2+2-$ $4+4$ posterior macrosetae; urotergites VI-VII with $3+3$ lateral anterior and $5+5$ posterior macrosetae. Urosternite I with $7+7$ (15+15 in C. iberica Sendra \& Condé, 2012), urosternites II-VII with 5+5, urosternite VIII with $2+2$ macrosetae. Males without $g_{1}$ glandular setae but with $a_{2}$ glandular setae on first urosternite appendages. Females with subcylindrical appendages with $a_{l}$ glandular setae.

\section{Habitat and distribution}

Two of the four species of Cestocampa occupy the subterranean habitat in caves from the south of the Italian Peninsula (C. gasparoi Bareth, 1988) and the east of the Iberian Peninsula (C. iberica). The other two are soil-dwelling species (C. italica (Silvestri, 1912) and C. balcanica Condé, 1986) that have been reported from the Italian Peninsula and Dinaric Mountains (Fig. 210).

\section{Key to the species of Cestocampa}

1. 1+1 medial posterior mesonotal and metanotal macrosetae

- Without medial posterior mesonotal and metanotal macrosetae

2. $1+1$ posterior macrosetae on urotergite I; $2+2$ posterior macrosetae on urotergite II; $5+5$ posterior macrosetae on urotergite IV; $6+6$ macrosetae on urosternite I

Cestocampa balcanica Condé, 1955

- Without posterior macrosetae on urotergites I-II; $4+4$ posterior macrosetae on urotergite IV; $15+15$ macrosetae on urosternite I

Cestocampa iberica Sendra \& Condé, 2012

3. $2+2$ posterior macrosetae on urotergite I; $4+4$ posterior macrosetae on urotergite III; $2+2$ lateral anterior macrosetae on urotergite IV; $3+3$ lateral anterior macrosetae on urotergite $\mathrm{V}$

Cestocampa italica (Silvestri, 1912)

- $1+1$ posterior macrosetae on urotergite I; $2+2$ posterior macrosetae on urotergite III; $1+1$ lateral anterior macrosetae on urotergite IV; $2+2$ lateral anterior macrosetae on urotergite $\mathrm{V}$

Cestocampa gasparoi Bareth, 1988

Cestocampa balcanica Condé, 1955

Cestocampa balcanica Condé, 1955: 57.

Diagnosis (Condé 1955a; Sendra et al. 2012a)

Non-troglomorphic species. With 25 antennomeres in a regenerated antenna; frontal process with nontubercular setae. Pronotum with $1+1 m a, 2+2 l a, 2+2 l p$ macrosetae; mesonotum with $1+1 m a, 3+3$ $l a, 2+2 l p, 1+1 \mathrm{mp}$ macrosetae; metanotum with 1+1 ma, 2+2 la, 2+2 lp, 1+1 mp macrosetae; long, barbed notal macrosetae; sparse smooth notal clothing setae. Two ventral tibial macrosetae; subequal small claws (1.03) with small lateral crests, posterior claw without a backward overhang. Urotergite I with $1+1$ post macrosetae; urotergites II-III with $2+2$ post macrosetae; urotergite IV with $1+1$ la, $5+5$ 
post macrosetae; urotergite $\mathrm{V}$ with $2+2(2+1)$ la, $5+5$ post macrosetae; urotergites VI-VII with $3+3$ la, $5+5$ post macrosetae; urotergite VIII with $6+6$ post macrosetae; abdominal segment IX with $8+8$ $(8+7)$ post macrosetae; urosternite I with $7+1+7$, urosternites II-VII with $5+5$, urosternite VIII with $2+2$ macrosetae. Male unknown; female subcylindrical appendages with $a_{1}$ glandular setae.

\section{Habitat and distribution}

Soil-dwelling species found in two remote localities, the type locality in Rabitlje, south-eastern Dinaric Mountains, and on Monti Aurunci, Lazio, central Italian Peninsula.

Cestocampa gasparoi Bareth, 1988

Cestocampa gasparoi Bareth, 1988: 49, fig 3a-f.

Diagnosis (Bareth 1988)

Troglomorphic species. Antennae with 27-29 antennomeres (perhaps regenerated); 12-13 simple olfactory chemoreceptors in cupuliform organ; frontal process with non-tubercular setae. Pronotum with $1+1 m a, 3+3-4+4 l a, 2+2$ lp macrosetae; mesonotum with $1+1 m a, 3+3 l a, 2+2 l p$ macrosetae; metanotum with $1+1 \mathrm{ma}, 2+2 \mathrm{la}, 2+2 \mathrm{lp}$ macrosetae; long, barbed notal macrosetae; notal setal clothing sparse, long, smooth or with two apical barbs. Two ventral tibial macrosetae; subequal small claws with small lateral crests, posterior claw without a backward overhang. Urotergite I with $1+1$ post macrosetae; urotergite II with $1+2$ post macrosetae; urotergite III with $2+2$ post macrosetae; urotergite IV with $1+1$ la, $5+5$ post macrosetae; urotergite $\mathrm{V}$ with $2+2$ la, $5+5$ post macrosetae; urotergites VI-VII with $3+3$ la, $5+5$ post macrosetae; urotergite VIII with $6+6$ post macrosetae; abdominal segment IX with $8+8$ post macrosetae; urosternite I with 7+7, urosternites II-VII with $5+5$, urosternite VIII with $2+2$ macrosetae. Male without glandular $g_{1}$ setae, enlarged subcylindrical appendages with thin and long glandular $a_{2}$ setae. Spermatozoid fascicle wheels with $2 \frac{1}{2}$ turns of $350 \mu \mathrm{m}$ long and $8 \mu \mathrm{m}$ wide filament. Female unknown.

\section{Habitat and distribution}

Subterranean species found in Grotta Superiore di Sant'Angelo Calabria, south Italian Peninsula.

Cestocampa iberica Sendra \& Condé, 2012

Cestocampa iberica Sendra \& Condé in Sendra et al., 2012a: 47, figs 2-3.

Diagnosis (Sendra et al. 2012a)

Troglomorphic species. Antennae with 34-41 antennomeres; 8-10 complex olfactory chemoreceptors in cupuliform organ; non-protruding frontal process with non-tubercular setae. Pronotum with $1+1 \mathrm{ma}$, $3+3$ la, $2+2$ lp macrosetae; mesonotum with $1+1 \mathrm{ma}, 3+3 \mathrm{la}, 2+2 \mathrm{lp}, 1+1 \mathrm{mp}$ macrosetae; metanotum with $1+1 m a, 2+2 l a, 2+2 l p, 1+1 m p$ macrosetae; middle-sized, barbed notal macrosetae; notal clothing setae sparse, smooth or with thin distal barbs. Two or three ventral tibial macrosetae; subequal claws (1.05-1.10) with large lateral crests, posterior claw without a backward overhang. Urotergite I with $1+1$ post macrosetae; urotergite II with $2+2$ post macrosetae; urotergite III with $1+1$ la, $2+2$ post macrosetae; urotergite IV with $1+1$ la, $4+4$ post macrosetae; urotergites V-VII with $3+3$ la, $5+5$ post macrosetae; urotergite VIII with $7+7$ post macrosetae; abdominal segment IX with $9+9$ post macrosetae; urosternite I with $15+15$, urosternites II-VII with 5+5, urotergite VIII with $2+2$ macrosetae. Male without glandular $g_{1}$ setae, enlarged subcylindrical appendages with glandular $a_{2}$ setae; female with subcylindrical appendages with glandular $a_{1}$ setae. Spermatozoid fascicle wheels with $1 \frac{1}{2}$ turns of $70-90 \mu \mathrm{m}$ long and 4-5 $\mu \mathrm{m}$ wide filament. 


\section{Habitat and distribution}

Subterranean species found in 11 caves around the Castilian-Valencian Branch of the Iberian Mountain Range and its border with the northwest of the Pre-Baetic Mountains, eastern Iberian Peninsula.

Cestocampa italica (Silvestri, 1912)

Plusiocampa italica Silvestri, 1912: 145, fig. xxx.

Diagnosis (Silvestri 1912; Condé 1955a)

Non-troglomorphic species. Antennae with 22 antennomeres. Pronotum with $1+1 \mathrm{ma}, 4+4 \mathrm{la}, 2+2 \mathrm{lp}$ macrosetae; mesonotum with $1+1 \mathrm{ma}, 3+3 \mathrm{la}, 2+2$ lp macrosetae; metanotum with $1+1 \mathrm{ma}, 2+2 \mathrm{la}, 2+2$ $l p$ macrosetae. Two ventral tibial macrosetae; subequal small claws with small lateral crests, posterior claw without a backward overhang. Urotergites I-II with $2+2$ post macrosetae; urotergite III with $4+4$ post macrosetae; urotergite IV with $2+2$ la, $5+5$ post macrosetae; urotergites $\mathrm{V}-\mathrm{VII}$ with $3+3$ la, $5+5$ post macrosetae; urosternite I with $7+7$, urosternites II-VII with $5+5$, urosternite VIII with $2+2$ macrosetae. Male without glandular $g_{1}$ setae and slightly enlarged appendages.

\section{Habitat and distribution}

Soil-dwelling species known from the type locality in Strongoli, Calabria, southern Italian Peninsula, and northern Macedonia.

\section{Hystrichocampa Condé, 1948}

Hystrichocampa Condé, 1948a: 5.

\section{Diagnosis}

Mesonotum and metanotum with medial posterior macrosetae. Five dorsal femoral macrosetae; one or two ventral and two dorsal tibial macrosetae. Unequal, elbow-like claws. Thick, subcylindrical, setiform, pubescent lateral process of pretarsus. Urotergites with up to $3+3$ lateral anterior and $5+5$ posterior macrosetae.

\section{Hystrichocampa pelletieri Condé, 1948}

Hystrichocampa pelletieri Condé, 1948a: 5, fig. 2.

Diagnosis (Condé 1948a, 1955a; Bareth 1968, 2006)

Troglomorphic species. Antennae with 31-36 antennomeres; 8 to 10 olfactory chemoreceptors in cupuliform organ; protruding frontal process with tubercular setae. Pronotum with $1+1 \mathrm{ma}, 4+4 \mathrm{la}$, $2+2 l p$ macrosetae; mesonotum with $1+1 \mathrm{ma}, 2+2 l a, 2+2 l p, 1+1 \mathrm{mp}$ macrosetae; metanotum with $1+1$ $m a, 1+1$ la $, 2+2 l p, 1+1 m p$ macrosetae; long, barbed notal macrosetae; sparse long, thin clothing setae. Unequal, elbow-like claws (1.2) with large lateral crests, posterior claw with a backward overhang. Urotergites I-II with $1+1$ post macrosetae; urotergite III with $1+1$ la, $1+1$ post macrosetae; urotergite IV with $1+1$ la, $4+4$ post macrosetae; urotergite $\mathrm{V}$ with $2+2$ la, $5+5$ post macrosetae; urotergites VIVII with $3+3$ la, $5+5$ post macrosetae; urotergite VIII with $6+6$ post macrosetae; urosternite I with $7+7$, urosternites II-VII with $5+5$, urosternite VIII with $2+2$ macrosetae. Male with glandular $g_{1}$ setae, enlarged subcylindrical appendages with glandular $a$, setae; female subcylindrical appendages with glandular $a_{1}$ setae. Spermatozoid fascicles $57-80 \mu \mathrm{m}$ in diameter and $7-9 \mu \mathrm{m}$ in width; wheels with $1 \frac{1}{2}$ turns of $150-200 \mu \mathrm{m}$ long and 7-8 $\mu \mathrm{m}$ thick filament. 


\section{Habitat and distribution}

Subterranean species widespread in the Jura karst mountains between France and Switzerland, where it is found in 18 caves (Fig. 210).

Patrizicampa Condé, 1962

Patrizicampa Condé, 1962: 199.

Diagnosis (Condé 1962)

Without dorsal femoral macrosetae or ventral tibial macrosetae; abundant macrosetae on all urosternites, including 3+3 macrosetae on urosternite VIII. Its apomorphic feature, the shape of the laminar pretarsal lateral process, is unique among diplurans. It starts with a large laminar lateral process, well barbed on the ventral side and ending in a thin, smooth, pointed process.

Patrizicampa sardoa Condé, 1962

Figs $1-2$

Patrizicampa sardoa Condé, 1962: 199, figs a-b.

Diagnosis (Condé 1962)

Troglomorphic species. Cupuliform organ with 10-14 complex olfactory chemoreceptors. Protruding frontal process with non-tubercular setae. Pronotum with $1+1 m a, 4+4 l a, 2+2 l p$ macrosetae; mesonotum

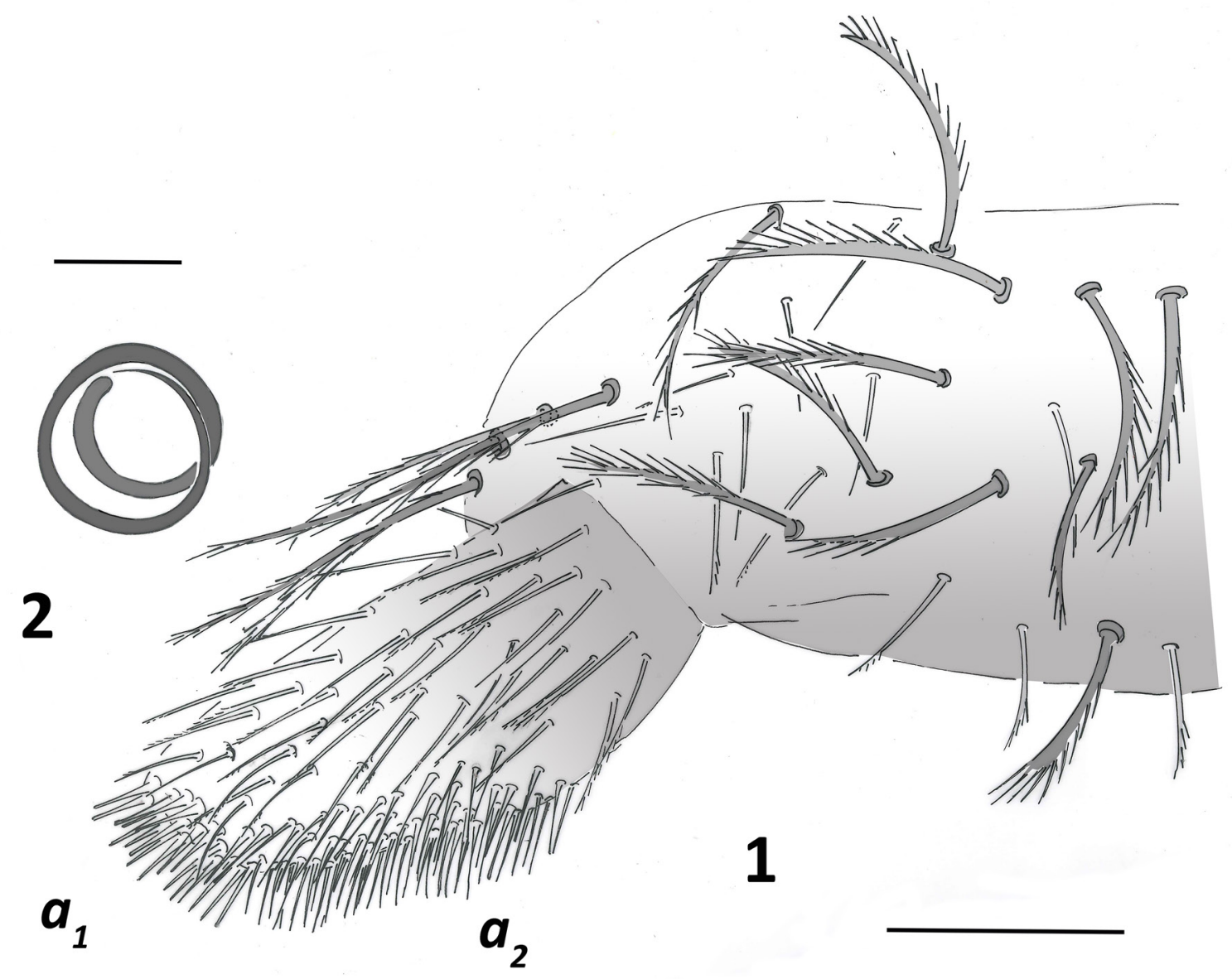

Figs 1-2. Patrizicampa sardoa Condé, 1956, 5 mm long đ̊, from Murgulavó Cave, Sardinia (Coll. AS). 1. First urosternite, right side. 2. Spiral filament. Scale bars: $20 \mu \mathrm{m}$. 
with $1+1 m a, 3+3 l a, 2+2 l p$ macrosetae; metanotum with $1+1 \mathrm{ma}, 3+3 \mathrm{la}, 2+2 \mathrm{lp}$ macrosetae; long, barbed notal macrosetae; long clothing setae covered with thin barbs. Subequal elbow-like claws (1.1) with large lateral crests, posterior claw with a backward overhang. Urotergite III with $1+1 l a, 0+0-1+1$ post macrosetae; urotergite IV with $2+2$ la, $1+1-3+3$ post macrosetae; urotergite $\mathrm{V}$ with $2+2-3+3$ la, 2+2-4+4 post macrosetae; urotergites VI-VII with $3+3$ la, $4+4$ post macrosetae; urotergite VIII with $6+6$ post macrosetae; abdominal segment IX with $8+8-8+9$ post macrosetae. Urosternite I with $15+15-$ $16+16$, urosternites II-VII with $7+7-8+8$, urosternite VIII with $3+3$ macrosetae. Male without glandular $g_{l}$ setae, slightly subtrapezoidal appendages with glandular $a_{1}$ and $a_{2}$ setae; females with subcylindrical appendages and an apical area with glandular $a_{l}$ setae.

\section{Remarks (Figs 1-2)}

The study of many specimens collected in 6 new caves (see Table S2 in Supplementary Material) allowed us to complete Condé's diagnosis, as well as to supplement it with some minor taxonomic details. Medial antennomeres with 10-12 gouge sensilla 40-50 $\mu \mathrm{m}$ long. End of metathoracic leg reaches end of abdomen; calcars covered with barbs; subapical setae with thin barbs almost from base up to twothirds of length. Stylus with an apical seta with a few thin barbs and a large, thick basal tooth, medial and subapical setae covered with thin barbs. Male appendages with up to 60 glandular $a_{2}$ setae and 20 $a_{1}$ glandular setae (Fig. 1); female appendages with up to $18 a_{1}$ glandular setae. Spermatozoid fascicle wheels with 2 turns of 140-160 $\mu \mathrm{m}$ long and up to $4 \mu \mathrm{m}$ wide filament (Fig. 2).

\section{Habitat and distribution}

Subterranean species found in eight caves in eastern Sardinia (Fig. 210).

\section{Plusiocampa Silvestri, 1912}

Plusiocampa Silvestri, 1912: 141.

\section{Diagnosis (Silvestri 1912; Condé 1955a; Sendra \& Weber 2018)}

Apparently smooth epicuticle, usually reticulated at high magnification, rosetta pores absent. Head with a frontal process with or without tuberculate setae. In non-troglomorphic species, cupuliform organ with four or five spheroidal olfactory chemoreceptors with polygonal net, with pore surface made by at least one cup-shaped fold and a central structure ending in a terminal pore. In troglobiomorphic species, spheroidal olfactory chemoreceptor with more folds in spiral, radial or other complex shape and a more visible polygonal net with pore surface. Sensillum of third antennomere in ventral position. Meso- and metathorax with a few macrosetae but frequently with medial anterior, lateral anterior, lateral posterior and medial posterior (exceptionally medial intermediate and lateral intermediate) macrosetae. Femur with one to five dorsal macrosetae; tibia with one to three ventral macrosetae. Elbow-like claws with usually large lateral crests and setiform lateral processes, rarely with a few barbs on proximal part. Abdomen with lateral anterior and posterior macrosetae and never with medial anterior macrosetae. Sternal macrosetae: sternite I with $6+6$ up to 60 macrosetae; sternites II-VII with $4+4$ to up to $14+14$ macrosetae; sternite VIII with $2+2$ up to $4+4$ macrosetae. Secondary sexual differences in shape of first urosternite appendages and number of glandular setae.

\section{Habitat and distribution}

This is the most diverse genus of Plusiocampinae, with a clear preference for the subterranean ecosystems (Condé 1955a; Sendra \& Weber 2018). It has 72 species (including the seven new ones described here) and 10 subspecies, distributed around the Mediterranean Basin (Figs 210-211). The exceptions are three Chinese species considered representatives of Plusiocampa by Silvestri (1931a), Condé (1993a) and Sendra et al. (2012a): P. sinensis Silvestri, 1931, P. lipsae Condé, 1993 and P. kashiensis Chou \& Tong, 
1980. Nevertheless, these species must be removed from Plusiocampa due to the macrosetal formula on urosternites II to VIII.

\section{Key to the subgenera and species of Plusiocampa}

The genus Plusiocampa has been divided into four subgenera based on two characters: the presence of the femoral dorsal macrosetae (Condé 1955a; Paclt 1957; Sendra \& Weber 2018) and the number of tibial ventral macrosetae (Bareth \& Condé 1984). Based on these synapomorphies and other characters, the following taxonomic key is proposed for the current five subgenera and 69 species.

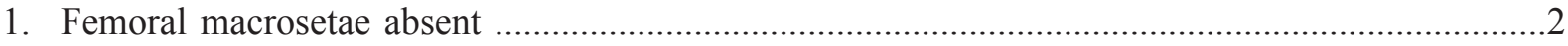

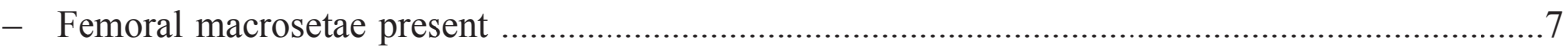

2. Lateral posterior mesonotal macrosetae absent

Plusiocampa (Stygiocampa) christiani Condé \& Bareth, 1996

- Lateral posterior mesonotal macrosetae present

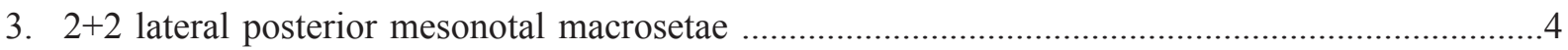

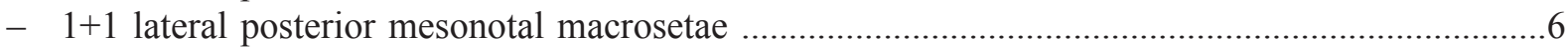

4. Lateral expansions on posterior side of first urosternite absent in adult males; males without $g_{1}$ glandular setae; urosternal appendages in adult males enlarged, thick and subcylindrical

Plusiocampa (Stygiocampa) nivea (Joseph, 1882)

- Lateral expansions on posterior side of first urosternite present in adult males; males with $g_{I}$ glandular setae; urosternal appendages in males subcylindrical

5. 1+1 medial anterior mesonotal and metanotal macrosetae; $2+2$ lateral anterior mesonotal macrosetae; 1+1 lateral anterior metanotal macrosetae .

Plusiocampa (Stygiocampa) dalmatica Condé, 1959

- Medial anterior mesonotal and metanotal macrosetae absent; 1+1 lateral anterior mesonotal macrosetae; lateral anterior metanotal macrosetae absent

Plusiocampa (Stygiocampa) remyi Condé, 1947

6. 2 ventral tibial macrosetae; unequal pretarsal claws (1.2-1.6); males with $g_{1}$ glandular setae; urosternal appendages in adult males subcylindrical ....

Plusiocampa (Stygiocampa) denisi Condé, 1947

- Ventral tibial macrosetae absent; slightly unequal pretarsal claws (1.1-1.2); males without $g_{I}$ glandular setae; urosternal appendages in adult males enlarged and subcylindrical

Plusiocampa (Stygiocampa) bureschi Silvestri, 1931

7. 5 dorsal femoral macrosetae

Plusiocampa (Pentachaetocampa) inopinata Sendra \& Weber, 2018

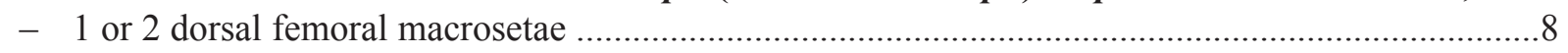

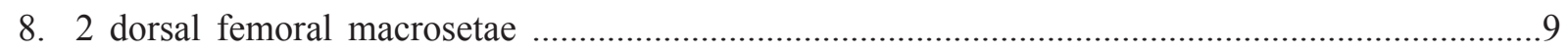

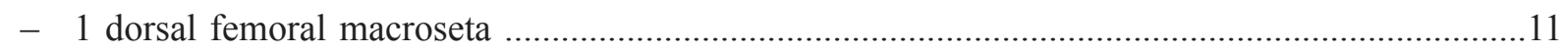

9. 1+1 medial posterior macrosetae on mesonotum and metanotum; pretarsal claws subequal (1.01.1); 5+5 macrosetae on urosternites II-VII .

Plusiocampa (Dydimocampa) alhamae Condé \& Sendra, 1989

- Medial posterior mesonotal and metanotal macrosetae absent; pretarsal claws unequal (1.2-1.6); 6+6 macrosetae on urosternites II-VII 
10. 3 ventral tibial macrosetae; $2+2$ lateral anterior mesonotal macrosetae; $4+4$ posterior macrosetae on urotergites IV-V

Plusiocampa (Dydimocampa) euxina Condé, 1996

- 2 ventral tibial macrosetae; 1+1 lateral anterior mesonotal macrosetae; 2+2 posterior macrosetae on urotergites IV-V Plusiocampa (Dydimocampa) evallonychia Silvestri, 1949

11. Pretarsal claws very unequal (1.6-2.5)

- Pretarsal claws subequal, slightly unequal or unequal (1.0-1.6)

12. Male urosternal appendages enlarged, thick and subcylindrical

- Male urosternal appendages enlarged and subcylindrical, or subcylindrical

13. $2+2$ lateral posterior metanotal macrosetae; $1+1$ lateral anterior metanotal macrosetae; 6+6 macrosetae on urosternite I; posterior macrosetae on urotergite VI absent

Plusiocampa (Venetocampa) ferrani Sendra \& Delić sp. nov.

- 1+1 lateral posterior metanotal macrosetae; lateral anterior metanotal macrosetae absent; 7+7 macrosetae on urosternite I; $2+2$ posterior macrosetae on urotergite VI

Plusiocampa (Venetocampa) paolettii Bareth \& Condé, 1984

14. Male urosternal appendages enlarged and subcylindrical

Plusiocampa (Plusiocampa) dublanskii Sendra \& Turbanov sp. nov.

- Male urosternal appendages subcylindrical

Plusiocampa (Plusiocampa) ternovensis Sendra \& Borko sp. nov.

15. Pretarsal claws subequal (1.0-1.1)

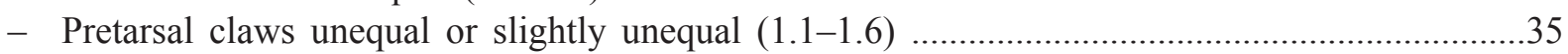

16. 1+1 medial posterior mesonotal macrosetae

- Medial posterior mesonotal macrosetae absent

17. Lateral anterior metanotal macrosetae present

- Lateral anterior metanotal macrosetae absent

18. $2+2$ lateral anterior metanotal macrosetae

- 1+1 lateral anterior metanotal macrosetae

19. Pretarsal lateral crests small; posterior claw without backward overhang; $2+2$ lateral anterior macrosetae on urotergite IV; shape of body and appendages non-troglomorphic .

.Plusiocampa (Plusiocampa) suspiciosa Condé \& Mathieu, 1957

- Pretarsal lateral crests large; posterior claw with backward overhang; 1+1 lateral anterior macrosetae on urotergite IV; troglomorphic body and appendages

20. $5+5$ posterior macrosetae on urotergites IV-VII

Plusiocampa (Plusiocampa) provincialis Condé, 1949

- $2+2$ posterior macrosetae on urotergites IV-V; 4+4 posterior macrosetae on urotergites VI-VII ...

Plusiocampa (Plusiocampa) socia Condé, 1983

21. Pretarsal lateral crests small

Plusiocampa (Plusiocampa) notabilis Silvestri, 1912

- Pretarsal lateral crests large

22. $8+8$ macrosetae on urosternite I

- $7+7$ macrosetae on urosternite I 
23. Posterior pretarsal claw without backward overhang; $2+2$ posterior macrosetae on urotergite III; $7+7$ posterior macrosetae on urotergite VIII; $1+1$ lateral anterior macrosetae on urotergite IV ..

Plusiocampa (Plusiocampa) lagoi Silvestri, 1932

- Posterior pretarsal claw with backward overhang; $1+1$ posterior macrosetae on urotergite III; $6+6$ posterior macrosetae on urotergite VIII; $2+2$ lateral anterior macrosetae on urotergite IV ..

.Plusiocampa (Plusiocampa) breuili Condé, 1955

24. $3+3$ lateral anterior mesonotal macrosetae

- $2+2$ lateral anterior mesonotal macrosetae

Plusiocampa (Plusiocampa) lagari Sendra \& Condé, 1987

25. $5+5$ posterior macrosetae on urotergite IV .....Plusiocampa (Plusiocampa) bonadonai Condé, 1948

- $3+3$ posterior macrosetae on urotergite IV

Plusiocampa (Plusiocampa) tinoamorei Sendra \& Nicolosi, 2019

26. Lateral anterior mesonotal macrosetae present

- Lateral anterior mesonotal macrosetae absent ...Plusiocampa (Plusiocampa) glabra Condé, 1984

27. $3+3$ lateral anterior mesonotal macrosetae

- $1+1$ or $2+2$ lateral anterior mesonotal macrosetae

28. $6+6$ posterior macrosetae on urotergites V-VII

Plusiocampa (Plusiocampa) apollo Sendra, Giachino \& Vailati sp. nov.

- $5+5$ posterior macrosetae on urotergites V-VII ...Plusiocampa (Plusiocampa)festae Silvestri, 1932

29. $2+2$ lateral anterior mesonotal macrosetae

Plusiocampa (Plusiocampa) rudnica Blesić, 1992

- 1+1 lateral anterior mesonotal macrosetae

Plusiocampa (Plusiocampa) chiosensis Sendra \& Gasparo sp. nov.

30. 2 ventral tibial macrosetae; $1+1$ lateral anterior macrosetae on urotergites IV-V 31

- 1 ventral tibial macroseta; lateral anterior macrosetae on urotergites IV-V absent

.Plusiocampa (Plusiocampa) dolichopoda Bareth \& Condé, 1984

31. Pretarsal lateral crests small

- Pretarsal lateral crests large

32. $3+3$ lateral anterior mesonotal macrosetae; $1+1$ lateral anterior metanotal macrosetae

- 2+2 lateral anterior mesonotal macrosetae; lateral anterior metanotal macrosetae absent

Plusiocampa (Plusiocampa) cyrnensis Condé, 1953

33. $5+5$ posterior macrosetae on urotergites IV-VII

Plusiocampa (Plusiocampa) exsulans Condé, 1947

- $3+3$ posterior macrosetae on urotergite IV; $4+4$ posterior macrosetae on urotergites V-VII

Plusiocampa (Plusiocampa) corcyraea Silvestri, 1912

34. Male urosternal appendages enlarged and subcylindrical; $2+2$ lateral anterior mesonotal macrosetae; lateral anterior metanotal macrosetae absent; posterior claw without backward overhang ...

Plusiocampa (Plusiocampa) lindbergi Condé, 1956

- Male urosternal appendages subcylindrical; 3+3 lateral anterior mesonotal macrosetae; 1+1 lateral anterior metanotal macrosetae; posterior claw with backward overhang

Plusiocampa (Plusiocampa) arbanasiensis Bareth \& Condé, 2001 


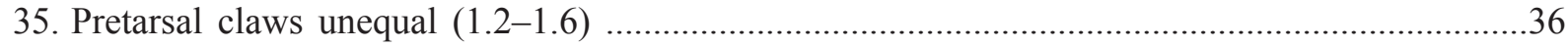

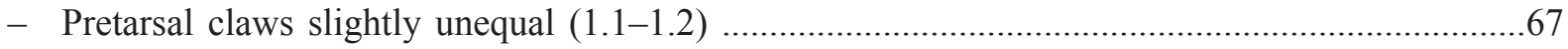

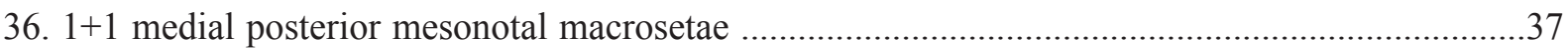

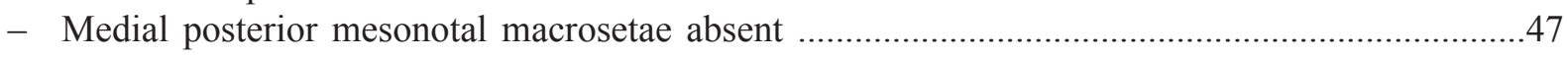

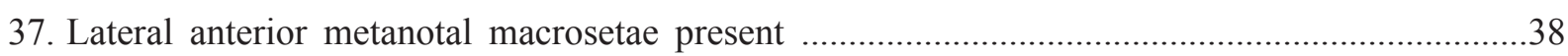

- Lateral anterior metanotal macrosetae absent

Plusiocampa (Plusiocampa) hoelzeli (Neuherz, 1984)

38. $2+2$ lateral anterior metanotal macrosetae

- $1+1$ lateral anterior metanotal macrosetae

39. 8+8 macrosetae on urosternite I; urosternal appendages in females enlarged and subcylindrical; 4-5 olfactory chemoreceptors; setae on frontal process slightly tuberculated

Plusiocampa (Plusiocampa) elongata Ionescu, 1955

- 7+7 macrosetae on urosternite I; urosternal appendages in females subcylindrical; more than 5 olfactory chemoreceptors; setae on frontal process tuberculated

40. $5+5$ posterior macrosetae on urotergites IV-VII

Plusiocampa (Plusiocampa) bulgarica Silvestri, 1931

- $4+4$ posterior macrosetae on urotergites IV-VII

Plusiocampa (Plusiocampa) vodniensis Bareth \& Condé, 2001

41.3 ventral tibial macrosetae

- 2 ventral tibial macrosetae

42. 3+3 lateral anterior mesonotal macrosetae

- $2+2$ lateral anterior mesonotal macrosetae

43. Male urosternal appendages enlarged and subcylindrical; $2+2$ posterior macrosetae on urotergite III; slightly troglomorphic body and appendages

Plusiocampa (Plusiocampa) caprai Condé, 1950

- Male urosternal appendages subcylindrical; 1+1 posterior macrosetae on urotergite III; troglomorphic body and appendages Plusiocampa (Plusiocampa) strouhali Silvestri, 1933

44. $6+6$ macrosetae on urosternites II-VII; $1+1$ posterior macrosetae on urotergite III; $2+2$ lateral anterior macrosetae on urotergites V-VI .......Plusiocampa (Plusiocampa) grandii Silvestri, 1933

- 5+5 macrosetae on urosternites II-VII; $2+2$ posterior macrosetae on urotergite III; $1+1$ lateral anterior macrosetae on urotergites V-VI ............Plusiocampa (Plusiocampa) fagei Condé, 1955

45. Subcylindrical male urosternal appendages enlarged; $3+3$ lateral anterior mesonotal macrosetae; slightly troglomorphic body and appendages

- Subcylindrical male urosternal appendages not enlarged; 2+2 lateral anterior mesonotal macrosetae; troglomorphic body and appendages

Plusiocampa (Plusiocampa) fagei Condé, 1955

46. Olfactory chemoreceptors simple; more than 5 olfactory chemoreceptors

Plusiocampa (Plusiocampa) friulensis Bareth \& Condé, 1984

- Olfactory chemoreceptor complex; 4-5 olfactory chemoreceptors

Plusiocampa (Plusiocampa) beroni Bareth \& Condé, 2001 
47. Ventral tibial macrosetae present

- Ventral tibial macrosetae absent Plusiocampa (Plusiocampa) dargilani (Moniez, 1894)

48. 3 ventral tibial macrosetae

- 1 or 2 ventral tibial macrosetae

49. 1+1 medial intermediate mesonotal and metanotal macrosetae; 1+1 lateral intermediate mesonotal and metanotal macrosetae; $4+4$ posterior macrosetae on urotergite VI

Plusiocampa (Plusiocampa) lucenti Sendra \& Condé, 1986

- Medial and lateral intermediate macrosetae absent on mesonotum and metanotum; $5+5$ posterior macrosetae on urotergite VI

50. 2+2 lateral anterior macrosetae on urotergites V-VII; olfactory chemoreceptors laminar

Plusiocampa (Plusiocampa) dallai Bareth \& Condé, 1984

- 1+1 lateral anterior macrosetae on urotergites V-VII; olfactory chemoreceptors simple

Plusiocampa (Plusiocampa) djurdjurae Condé, 1984

51. 2 ventral tibial macrosetae

- 1 ventral tibial macroseta

52. $3+3$ lateral posterior metanotal macrosetae

.Plusiocampa (Plusiocampa) pouadensis (Denis, 1930)

- $1+1$ or $2+2$ lateral posterior metanotal macrosetae

53. $2+2$ lateral posterior metanotal macrosetae

- 1+1 lateral posterior metanotal macrosetae

54. Urosternal appendages in adult males subtrapezoidal or subtriangular .55

- Urosternal appendages in adult males subcylindrical, enlarged and subcylindrical, or enlarged, thick and subcylindrical

55. $3+3$ lateral anterior mesonotal macrosetae; $5+5$ macrosetae on urosternites II-VII; $2+2$ posterior macrosetae on urotergite III; $5+5$ posterior macrosetae on urotergite IV

..Plusiocampa (Plusiocampa) isterina Condé, 1993

- 2+2 lateral anterior mesonotal macrosetae; 6+6 macrosetae on urosternites II-VII; $1+1$ posterior macrosetae on urotergite III; $2+2$ posterior macrosetae on urotergite IV

Plusiocampa (Plusiocampa) balsani Condé, 1947

56. Urosternal appendages in adult males enlarged, thick and subcylindrical

Plusiocampa (Plusiocampa) isterina Condé, 1993

- Urosternal appendages in adult males subcylindrical, or enlarged and subcylindrical .................57

57. Urosternal appendages in adult males enlarged and subcylindrical

- Urosternal appendages in adult males subcylindrical

58. 1+1 lateral intermediate mesonotal and metanotal macrosetae; $1+1$ medial intermediate mesonotal and metanotal macrosetae; $1+1$ lateral anterior macrosetae on urotergite III

..Plusiocampa (Plusiocampa) lucenti Sendra \& Condé, 1986

- Medial and lateral intermediate macrosetae absent on mesonotum and metanotum; lateral anterior macrosetae absent on urotergite III 
SENDRA A. et al., Euro-Mediterranean Plusiocampinae and tachycampoid diplurans

59. Posterior macrosetae present on urotergite III

- Posterior macrosetae absent on urotergite III

Plusiocampa (Plusiocampa) gueorguievi Bareth \& Condé, 2001

60. $2+2$ posterior macrosetae on urotergite III 61

$-1+1$ posterior macrosetae on urotergite III

61. $5+5$ posterior macrosetae on urotergite IV; pretarsal lateral processes long; non-troglomorphic body and appendages; olfactory chemoreceptors simple

.Plusiocampa (Plusiocampa) isterina Condé, 1993

- $2+2$ posterior macrosetae on urotergite IV; pretarsal lateral processes short; troglomorphic body and appendages; olfactory chemoreceptors complex

Plusiocampa (Plusiocampa) dobati Condé, 1975

62. Urosternal appendages in adult females enlarged and subcylindrical; olfactory chemoreceptors complex Plusiocampa (Plusiocampa) schweitzeri Condé, 1947

- Urosternal appendages in adult females subcylindrical; olfactory chemoreceptors simple

Plusiocampa (Plusiocampa) djurdjurae Condé, 1984

63. 5+5 posterior macrosetae on urotergite IV ......Plusiocampa (Plusiocampa) isterina Condé, 1993

- $2+2$ or $3+3$ posterior macrosetae on urotergite IV

64. 3+3 posterior macrosetae on urotergite IV ......Plusiocampa (Plusiocampa) latens Condé, 1948

- 2+2 posterior macrosetae on urotergite IV ......Plusiocampa (Plusiocampa) affinis Condé, 1947

65. $1+1$ medial anterior metanotal macrosetae; $3+3$ posterior macrosetae on urotergites VI-VII; $6+6$ posterior macrosetae on urotergite VIII ........Plusiocampa (Plusiocampa) vedovinii Condé, 1981

- Medial anterior metanotal macrosetae absent; 4+4 posterior macrosetae on urotergites VI-VII; 5+5 posterior macrosetae on urotergite VIII ....Plusiocampa (Plusiocampa) hoelzeli (Neuherz, 1984)

66. 2+2 lateral posterior metanotal macrosetae; urosternal appendages in adult males subtrapezoidal or subtriangular; 1+1 medial anterior metanotal macrosetae; $a_{2}$ glandular setae present in adult males

Plusiocampa (Plusiocampa) balsani Condé, 1947

- 1+1 lateral posterior metanotal macrosetae; urosternal appendages in adult males enlarged and subcylindrical; medial anterior metanotal macrosetae absent; $a_{2}$ glandular setae absent in adult males Plusiocampa (Plusiocampa) hoelzeli (Neuherz, 1984)

67. 1+1 medial posterior mesonotal and metanotal macrosetae .68

- Medial posterior mesonotal and metanotal macrosetae absent .....................................................79

68. Lateral anterior metanotal macrosetae present

- Lateral anterior metanotal macrosetae absent ...Plusiocampa (Plusiocampa) rhea Sendra sp. nov.

69. $2+2$ lateral anterior metanotal macrosetae .70

- 1+1 lateral anterior metanotal macrosetae .72

70. 4+4 posterior macrosetae on urotergite III ......Plusiocampa (Plusiocampa) romana Condé, 1954

- $2+2$ or $3+3$ posterior macrosetae on urotergite III ....................................................................

71. $3+3$ posterior macrosetae on urotergite III

Plusiocampa (Plusiocampa) hystricula Bareth \& Condé, 1984

- $2+2$ posterior macrosetae on urotergite III ....Plusiocampa (Plusiocampa) sardiniana Condé, 1981 
72. 4 ventral tibial macrosetae Plusiocampa (Plusiocampa) magdalenae Condé, 1957

- 2 or 3 ventral tibial macrosetae

73. 3 ventral tibial macrosetae

- 2 ventral tibial macrosetae

74. $7+7$ posterior macrosetae on urotergite VIII; $1+1$ lateral anterior macrosetae on urotergite III ... .Plusiocampa (Plusiocampa) hoffmanni Sendra \& Paragamanm sp. nov.

- $6+6$ posterior macrosetae on urotergite VIII; lateral anterior macrosetae on urotergite III absent

75. $5+5$ posterior macrosetae on urotergite IV; $2+2$ lateral anterior macrosetae on urotergite IV; $3+3$ lateral anterior macrosetae on urotergites V-VI

Plusiocampa (Plusiocampa) magdalenae Condé, 1957

- $3+3$ posterior macrosetae on urotergite IV; $1+1$ lateral anterior macrosetae on urotergites IV-VI Plusiocampa (Plusiocampa) tinoamorei Sendra \& Nicolosi, 2019

76. Posterior pretarsal claw without backward overhang

Plusiocampa (Plusiocampa) humicola Ionescu, 1951

- Posterior pretarsal claw with backward overhang

77. $2+2$ posterior macrosetae on urotergite III; non-troglomorphic body and appendages; $4-5$ simple olfactory chemoreceptors Plusiocampa (Plusiocampa) spelaea Stach, 1930

- $1+1$ posterior macrosetae on urotergite III; troglomorphic body and appendages; more than 5 complex olfactory chemoreceptors

78. Urosternal appendages in adult males enlarged, thick and subcylindrical; $7+7$ posterior macrosetae on urotergite VIII; 1+1 lateral anterior macrosetae on urotergite III; setae on frontal process tuberculated

Plusiocampa (Plusiocampa) hoffmanni Sendra \& Paragamian sp. nov.

- Urosternal appendages in adult males subcylindrical; $6+6$ posterior macrosetae on urotergite VIII; lateral anterior macrosetae on urotergite III absent; setae on frontal process slightly tuberculated .Plusiocampa (Plusiocampa) tinoamorei Sendra \& Nicolosi, 2019

79. Lateral anterior mesonotal macrosetae present

- Lateral anterior mesonotal macrosetae absent ...Plusiocampa (Plusiocampa) baetica Sendra, 2004

80. $3+3$ lateral anterior mesonotal macrosetae .....Plusiocampa (Plusiocampa) bonneti Condé, 1948

- $2+2$ lateral anterior mesonotal macrosetae

81. $2+2$ lateral anterior metanotal macrosetae; $5+5$ posterior macrosetae on urotergites VI-VII; posterior macrosetae on urotergite I absent ....Plusiocampa (Plusiocampa) gadorensis Sendra, 2001

- 1+1 lateral anterior metanotal macrosetae; 4+4 posterior macrosetae on urotergites VI-VII; 1+1 posterior macrosetae on urotergite I ....Plusiocampa (Plusiocampa) solerii Silvestri, 1932

Subgenus Dydimocampa Paclt, 1957

Dydimocampa Paclt, 1957: 46.

Diagnosis (Paclt 1957; Condé 1996)

Dydimocampa shares with Plusiocampa s. str. the same taxonomic features, with the exception of the two dorsal femoral macrosetae. This fact, together with their distribution patterns, suggests that 
SENDRA A. et al., Euro-Mediterranean Plusiocampinae and tachycampoid diplurans

Dydimocampa is an artificial subgenus based on a single apomorphic feature that has probably appeared several times in Plusiocampa s. str.

\section{Habitat and distribution}

The three species treated here are cave-dwellers with a subterranean life-style and they are distributed in three disjunct karst areas in Europe (Fig. 211).

Plusiocampa (Dydimocampa) alhamae Condé \& Sendra, 1989

Plusiocampa alhamae Condé \& Sendra, 1989: 612, figs 1-3, tables 1-3.

Diagnosis (Condé \& Sendra 1989)

Troglomorphic species. Antennae with 35-40 antennomeres; up to 17 digitiform complex olfactory chemoreceptors on cupuliform organ; slightly protruding frontal process with tubercular setae. Pronotum with $1+1 m a, 3+3 l a, 2+2 l p$ macrosetae; mesonotum with $1+1 m a, 2+2 l a, 2+2 l p, 1+1 m p$ macrosetae; metanotum with 1+1 ma, 1+1 la, 2+2 lp, 1+1 mp macrosetae; long, barbed notal macrosetae with thin barbs; sparse long, barbed notal clothing setae. Two to four ventral tibial macrosetae, femur/tibia ratio 0.69; subequal, elbow-like claws with large lateral crests, posterior claw with a small backward overhang; long lateral process. Urotergites I-II with $1+1$ post macrosetae; urotergite III with $0+0-1+1$ la, $1+1$ post macrosetae; urotergite IV with $1+1$ la, $2+2-4+4$ post macrosetae; urotergite $\mathrm{V}$ with $1+1$ la, 4+4-5+5 post macrosetae; urotergites VI-VII with $1+1$ la, 5+5 post macrosetae; urotergite VIII with $6+6$ post macrosetae; abdominal segment IX with up to $8+8$ macrosetae; urosternite I with $7+7$, urosternites II-VII with 5+5, urosternite VIII with $2+2$ macrosetae. Male with an area of glandular $g_{1}$ setae, subcylindrical appendages with glandular $a$, setae; female appendages like male appendages. Spermatozoid fascicle wheels with $1 \frac{1}{2}$ turns of $100-140 \mu \mathrm{m}$ long and $2 \mu \mathrm{m}$ wide filament.

\section{Habitat and distribution}

Troglomorphic species found in four caves around the Sub-Baetic Interior Mountain Range, from Antequera (Málaga) to Sierra María (Almería), southern Iberian Peninsula.

Plusiocampa (Dydimocampa) euxina Condé, 1996

Plusiocampa euxina Condé, 1996: 102, figs 1-6.

Diagnosis (Condé 1996)

Troglomorphic species. Antennae with 44-45 antennomeres; eight to ten complex olfactory chemoreceptors in cupuliform organ; slightly protruding frontal process with a few anterior tubercular setae. Pronotum with $1+1 m a, 1+1 l a, 2+2 l p$ macrosetae; mesonotum with $1+1 m a, 2+2 l a, 2+2 l p$ macrosetae; metanotum with $1+1 m a, 1+2 l a, 2+2$ lp macrosetae; long, barbed notal macrosetae; sparse short, smooth notal clothing setae. Three ventral tibial macrosetae; unequal claws (1.25) with large lateral crests, posterior claw with a small backward overhang; short lateral processes. Urotergites I-III with $1+1$ post macrosetae; urotergite IV with $1+1$ la, $4+4$ post macrosetae; urotergite $\mathrm{V}$ with $2+2$ la, $4+4$ post macrosetae; urotergites VI-VII with $2+2$ la, $5+4$ post macrosetae; urotergite VIII with $6+6$ post macrosetae; abdominal segment IX with $9+9$ post macrosetae; urosternite I with $8+7$, urosternites II-VII with $6+6$, urosternite VIII with $2+2$ macrosetae. Male without glandular $g_{1}$ setae, enlarged subcylindrical appendages with a large area of glandular $a_{l}$ setae; adult female unknown.

\section{Habitat and distribution}

Subterranean species inhabiting the Movile Cave, Southern Dubrudja, Romania. 
Table 1. Plusiocampa (Dydimocampa) evallonychia Silvestri, 1949. Length of the body, antennae, metathoracic legns and cerci (measurements in $\mathrm{mm}$ ), in addition to the number of antennomeres and cercal articles.

\begin{tabular}{ccccccc}
\hline $\begin{array}{c}\text { Specimens } \\
\text { (Coll. AS) }\end{array}$ & $\begin{array}{c}\text { Body } \\
\text { length }\end{array}$ & $\begin{array}{c}\text { No. of } \\
\text { antennomeres }\end{array}$ & $\begin{array}{c}\text { Antenna } \\
\text { length }\end{array}$ & $\begin{array}{c}\text { Metathoracic } \\
\text { leg length }\end{array}$ & $\begin{array}{c}\text { No. of } \\
\text { cercal articles }\end{array}$ & $\begin{array}{c}\text { Cercus } \\
\text { length }\end{array}$ \\
\hline juv., Mamut-Tshokarak Cave & 3.45 & 40 & 3.10 & 1.8 & - & - \\
\&, Mamut-Tshokarak Cave & 4.9 & 35 & 5.3 & 3.3 & base +6 & 9.20 \\
+, Kuban Cave & 5.2 & - & - & 2.95 & - & - \\
中, Nassonova Cave & 5.3 & 34 & 4.3 & - & - & - \\
\hline
\end{tabular}

Plusiocampa (Dydimocampa) evallonychia Silvestri, 1949

Figs 3-8; Table 1

Plusiocampa evallonychia Silvestri, 1949: 29, figs ii-iii.

Diagnosis (Silvestri 1949; Condé 1996)

Troglomorphic species. Antennae with 33 antennomeres. Protruding frontal process with tubercular setae. Pronotum with $1+1 m a, 2+2 l a, 2+2 l p$ macrosetae; mesonotum with $1+1 m a, 1+1 l a, 2+2 l p$ macrosetae; metanotum with $1+1 \mathrm{ma}, 2+2$ lp macrosetae; long, barbed macrosetae. Two ventral tibial macrosetae; unequal claws with large lateral crests, posterior claw with a backward overhang; short lateral anterior process and long lateral posterior process. Urotergites I-III with $1+1$ post macrosetae; urotergites IV-VI with $1+1$ la, $2+2$ post macrosetae; urotergite VII with $1+1$ la, $5+5$ post macrosetae. Urosternite I with $7+7$, urosternites II-VII with $6+6$, urosternite VIII with $2+2$ macrosetae. Male unknown; female with subcylindrical appendages with glandular $a_{l}$ setae.

\section{Remarks}

The study of four specimens, a juvenile and 3 females, collected in three caves (see Table S2 in Supplementary Material) allowed a comparison with the species description, but new topotype material is needed to clarify the taxonomic status of this species (Table 1). The epicuticle of dorsal sclerites is reticulate when observed in high magnification (Fig. 6). Antennae with 34 and 35 antennomeres in two adults, and 40 in the juvenile; adult medial antennomeres $1.6 \times$ as long as wide, apical antennomere $2.5 \times$ as long as wide; one distal whorl with 20-22 gouge sensilla in each medial and distal antennomere, 36$38 \mu \mathrm{m}$ in length (Fig. 4). Cupuliform organ occupies $1 / 5$ of total length of last antennomere, with more than ten spheroidal olfactory chemoreceptors with a central column unfolded in complex expansions with a visible polygonal net with porous surface (Fig. 3). Protruding frontal process with abundant tubercular setae (Fig. 5). Pronotum with $3+3 l a$ macrosetae (2+2 la in original description). Unequal claws (1.4-1.5) with large lateral crests (Fig, 7), posterior claw with a large backward overhang; short lateral anterior pretarsal processes, less than half length of claw, and long lateral posterior pretarsal anterior process overpassing end of claw, as described in type form. Calcars with two rows of long barbs almost from base; smooth subapical tarsal setae. Urotergites with important differences from type form: $2+2(3+2) l a$ and $4+4-5+5$ post on urotergites VI-VII; $6+6$ post on urotergite VII; 9+9 post macrosetae on abdominal segment IX (undescribed in type form). Stylar setae with a few long, thin barbs. Urosternite I with 7+7, urosternites II-VII with 6+6, urosternite VIII with $2+2$ macrosetae (Fig. 8). Cerci $1.9 \times$ as long as body, with only 6 articles plus base.

\section{Habitat and distribution}

Subterranean species found in four caves, including the type locality in the I-El Koba (= Kizil-Koba, Krasnaya) Cave in the Crimean Mountains. The occurrence of such a distribution for $P$. (D.) evallonychia 
in the currently unrelated isolated karst regions of the Crimean Mountains is probably associated with the recent colonization of the caves by the edaphic form of this species in the Würm glacial stage. Such a recent isolation of the populations of this species might explain the absence of differences between them.
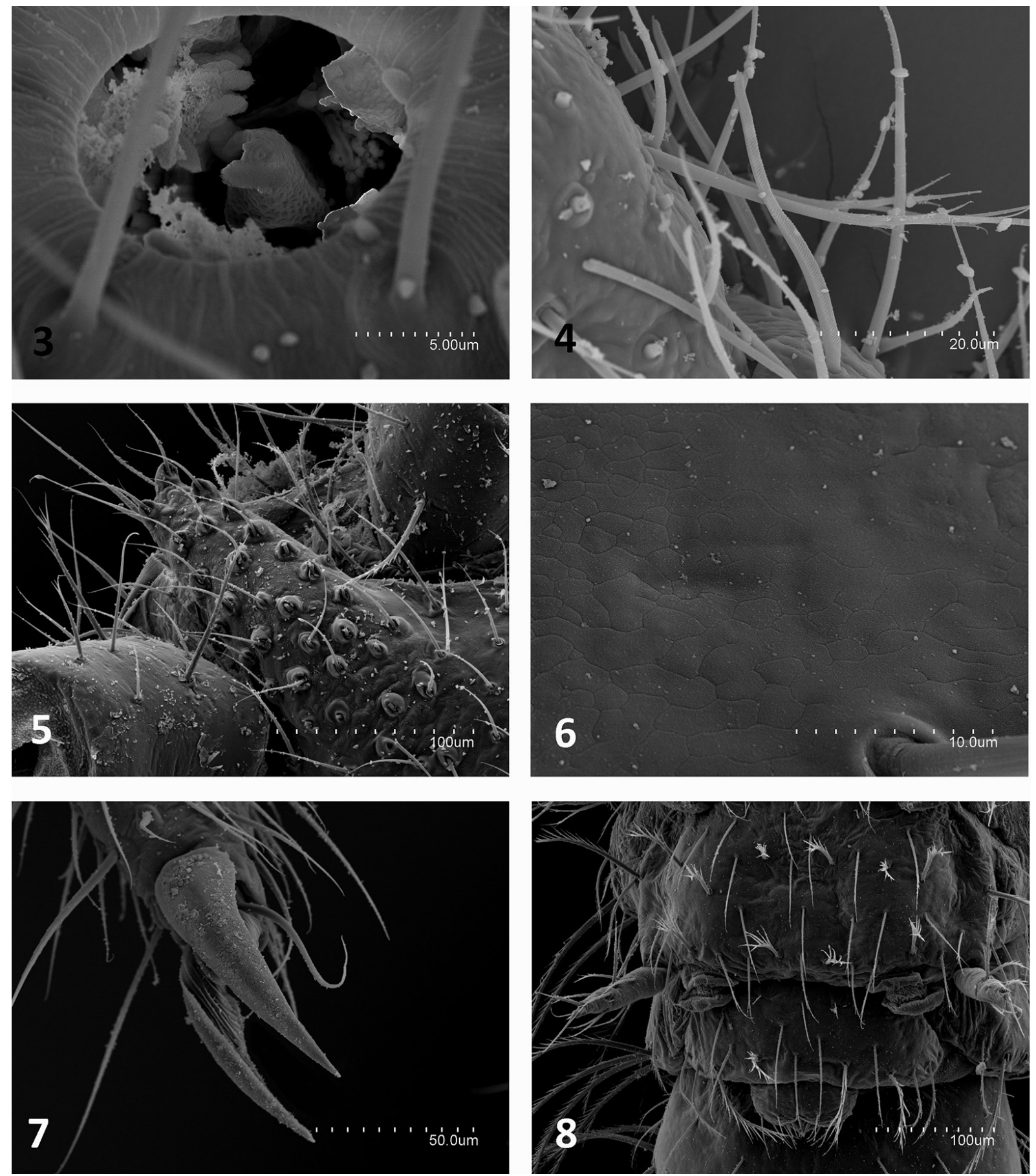

Figs 3-8. Plusiocampa (Dydimocampa) evallonychia Silvestri, 1949, from Mamut-Tshokrak Cave, Baidarsko-Balaklavsky karst massif, Crimean Peninsula (Coll. AS). 3. Cupuliform organ. 4. Lateral side of a middle antennomere with several gouge sensilla. 5. Frontal process. 6. Surface of metanotum. 7. Metathoracic claws. 8. Urosternites VII-IX. 
Subgenus Pentachaetocampa Sendra \& Weber, 2018

Pentachaetocampa Sendra \& Weber, 2018: 3.

Diagnosis (Sendra \& Weber 2018)

Mesothoracic and metathoracic femora with five dorsal macrosetae, up to three on prothoracic femur; presence of a narrow area of glandular $g_{1}$ setae in adult females.

Plusiocampa (Pentachaetocampa) inopinata Sendra \& Weber, 2018

Plusiocampa (Pentachaetocampa) inopinata Sendra \& Weber, 2018: 5, figs 1-17, table 1.

Diagnosis (Sendra \& Weber 2018)

Troglomorphic species. Sparse thin and long clothing notal setae with thin barbs. Antennae in adults with 32-33 antennomeres. Cupuliform organ with 12-14 complex olfactory chemoreceptors. Frontal process developed, with slightly tubercular setae and macrosetae. Pronotum with $1+1 \mathrm{ma}, 4+4 \mathrm{la}, 2+2 \mathrm{lp}$ macrosetae; mesonotum with $1+1 \mathrm{ma}, 3+3 \mathrm{la}, 2+2 \mathrm{lp}, 1+1 \mathrm{mp}$ macrosetae; metanotum with $1+1 \mathrm{ma}, 1+1$ $l a, 2+2 l p, 1+1 \mathrm{mp}$ macrosetae; long, thin macrosetae, with very thin barbs; subequal to slightly unequal claws (posterior claw 1.05-1.15) with large lateral crests; posterior claw with backward overhang; pretarsal lateral process long, smooth and setiform with several short proximal barbs. Urotergites I-II with $1+1$ post macrosetae; urotergite III with $1+1$ la $1+1$ post macrosetae; urotergite IV with $1+1$ la, $2+2(3+2,3+3)$ post macrosetae; urotergites $\mathrm{V}-\mathrm{VII}$ with $1+1$ la, $5+5$ post macrosetae; urotergite VIII with $6+6(5+6,5+5)$ post macrosetae; abdominal segment IX with $8+8(8+7)$ post macrosetae. Urosternite I with $7+7(7+6)$, urosternites II-VII with $5+5$, urosternite VIII with $2+2$ macrosetae. Male with a narrow area with glandular $g_{l}$ setae, enlarged subcylindrical appendages with glandular $a_{l}$ setae; female with glandular $g_{l}$ setae with subcylindrical appendages, thinner than in male.

\section{Habitat and distribution}

Monotypic subgenus known only from a single cave in southwest Germany (Fig. 211).

Subgenus Plusiocampa s. str. Silvestri, 1912

\section{Diagnosis (Silvestri 1912; Condé 1955a; Sendra \& Weber 2018)}

Lateral crests on claws from small to large, with subequal to very unequal, elbow-like claws; one dorsal femoral; from one to four ventral tibial macrosetae; setifom and smooth (in several species with a few proximal barbs) pretarsal lateral processes. Sternite I with $6+6-9+9$, sternites II-VII with $4+4-7+7$ and sternite VIII with $2+2$ macrosetae (with the exception of $P$. (P.) dargilani). Cerci elongated, with long articles covered in long, thin macrosetae with thin barbs and thin, smooth clothing setae.

\section{Habitat and distribution}

Within humid soils and MSS, but with a preference for the deep subterranean spaces found in caves, including the deepest caves in the world. The 60 species and 9 subspecies of this subgenus are wellspread around the Euro-Mediterranean region, from Southern Europe, including a small karst area in North Africa (Kabylian Mountains, Tell Atlas), throughout south of Central to Southeastern Europe and also reaching some spots in the Anatolian and Crimean peninsulas and Western Caucasus (Fig. 211).

Plusiocampa (Plusiocampa) affinis Condé, 1947

Plusiocampa affinis Condé, 1947a: 25, fig. 4. 
Diagnosis (Condé 1947a)

Non-troglomorphic species. Antennae with 23-26 antennomeres. Pronotum with $1+1 \mathrm{ma}, 3+3 \mathrm{la}, 2+2$ lp macrosetae; mesonotum with $1+1 \mathrm{ma}, 3+3 \mathrm{la}, 2+2$ lp macrosetae; metanotum with $1+1 \mathrm{ma}, 1+1 \mathrm{la}$, $2+2$ lp macrosetae; long, barbed notal macrosetae; smooth or distally barbed notal clothing setae. Two ventral tibial macrosetae; unequal claws (1.30) with large lateral crests, posterior claw with backward overhang. Urotergites I-II with $1+1$ post macrosetae; urotergite III with $1+1$ la $1+1$ post macrosetae; urotergite IV with $1+1$ la, $2+2$ post macrosetae; urotergites V-VII with $1+1$ la, $4+4$ post macrosetae; urosternite I with $7+7$, urosternites II-VII with $5+5$, urosternite VIII with $2+2$ macrosetae. Male with an area of glandular $g_{1}$ setae, subcylindrical appendages with glandular $a_{1}$ setae; female appendages like male appendages.

\section{Habitat and distribution}

This species is only known from Županska pećina, Lubnice, Berane Municipality, Montenegro.

Plusiocampa (Plusiocampa) apollo Sendra, Giachino \& Vailati sp. nov. urn:1sid:zoobank.org:act:6B496C95-E094-4688-BE14-60BDDE1105C8

Figs 9-11; Table 2

\section{Etymology}

The specific name 'apollo' is proposed since the Parnassos Mountain, its type locality, is the home of the divinity 'Apollo'.

\section{Material examined}

Holotype

GREECE • 1 q; Viotìa, O. Parnassós, crevices; 1660 m a.s.1.; 20 Jun. 2004-9 Jun. 2005; Pier Mauro Giachino and Dante Vailati leg.; MSS habitat; pitfall trap; MZB 2019-1032.

\section{Paratypes}

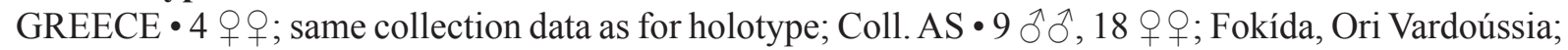
1575 m a.s.l.; 10 Jun. 2005-8 Jun. 2006; Pier Mauro Giachino and Dante Vailati leg.; MSS habitat; pitfall trap; Coll. AS.

\section{Description}

Body. Body length 4.5 to $6.1 \mathrm{~mm}$ (females) and 5.0 to $6.4 \mathrm{~mm}$ (males). Epicuticle smooth under optical microscope; body with thin, middle-sized clothing, covered or not by a few thin barbs.

HeAD. Two intact antennae in a $5.6 \mathrm{~mm}$ long female paratype with 28 antennomeres and a $5.1 \mathrm{~mm}$ long female paratype with 32 antennomeres, in both shorter than body length (Table 2). Small subcylindrical sensillum of third antennomere located in ventral position between $c$ and $d$ macrosetae. Central antennomeres $1.8 \times$ as long as wide, apical antennomere $2.0 \times$ as long as wide. Cupuliform organ occupying $1 / 4$ of total length of apical antennomere, with 8-9 complex olfactory chemoreceptors. Gouge sensilla $30-38 \mu \mathrm{m}$ long, in a single distal whorl of 16-18 sensilla on each medial and distal antennomere. Frontal process plain, with non-tubercular setae and macrosetae with a few barbs along distal half; macrosetae along line of insertion of antennomere and $x$ setae longer than other macrosetae $(a / i / p / x$ with relative lengths of 40/48/37/68 in holotype). Suboval labial palps with a small, coniform lateroexternal sensillum, with two guard setae, up to 9 setae on anterior border and up to 190 neuroglandular setae. 
Table 2. Plusiocampa (Plusiocampa) apollo Sendra, Giachino \& Vailati sp. nov. Length of the body, antennae and metathoracic legs (measurements in $\mathrm{mm}$ ), in addition to the number of antennomeres.

\begin{tabular}{|c|c|c|c|c|}
\hline \multirow{2}{*}{ Specimen } & \multirow{2}{*}{ Body length } & \multicolumn{3}{|c|}{ Antennae } \\
\hline & & No. of antennomeres & Length & Metathoracic leg length \\
\hline q, paratype (Coll. AS) & 4.5 & - & - & 2.3 \\
\hline †, paratype (Coll. AS) & 4.7 & - & - & 2.5 \\
\hline o, holotype (MZB 2019-1032) & 4.8 & - & - & 2.6 \\
\hline O, paratype (Coll. AS) & 5.0 & - & - & 2.7 \\
\hline , paratype (Coll. AS) & 5.0 & - & - & 2.6 \\
\hline + , paratype (Coll. AS) & 5.1 & 32 & 3.7 & 2.4 \\
\hline , paratype (Coll. AS) & 5.6 & 28 & 3.1 & 2.8 \\
\hline §, paratype (Coll. AS) & 6.2 & - & - & 2.8 \\
\hline §, paratype (Coll. AS) & 6.4 & - & - & 3.2 \\
\hline
\end{tabular}

THORAX. Thoracic macrosetal distribution (Fig. 9): pronotum with $1+1 m a, 2+2 l a_{3,4}$ and $3+3$ sla, $2+2 l p_{2,3}$ (additionally, $1+1$ extra sma appear near sagittal plane); mesonotum with $1+1 m a, 3+3 l a_{1,2,3}, 2+2 l p_{2,3}$, $1+1 \mathrm{mp}$; metanotum with $1+1 \mathrm{ma}, 2+2 l p_{2,3}, 1+1 \mathrm{mp}$. All notal macrosetae long and robust, covered by thin barbs almost from their base; submacrosetae sla and sma thinner and shorter than notal macrosetae, but with same large base; marginal setae longer than clothing setae, covered by thin barbs along distal half. Legs elongated, pretarsus of metathoracic legs slightly overpassing end of abdomen (Table 2). Femur I without dorsal macrosetae, but with one long, barbed ventral macroseta; femora II-III with one long, barbed dorsal and one long, barbed ventral macroseta. Tibia I with one short, barbed ventral macroseta; tibiae II-III with two short, barbed ventral macrosetae. Calcars with 2-3 rows of long barbs from base to tip, smooth on one narrow side along calcar. Dorsal and lateral subapical tarsal setae smooth. Subequal claws (posterior claw $1.1 \times$ as long as anterior one); posterior claw without backward overhang; lateral crests well developed. Pretarsal process long and setiform, reaching extremities of claws.

AвDomen. Distribution of abdominal macrosetae on tergites (Fig. 10): $1+1$ post $_{1}$ on I-III; $1+1$ la, $3+3$ (also 2+2, but less frequent) post $t_{1,2,3}$ on IV; $1+1$ la, 6+6 post ${ }_{1-5}$ on V-VII; 8+8 post on VIII; $10+10$ post on abdominal segment IX. All post urotergal macrosetae thick, long and covered by thin barbs along distal four-fifths; la urotergal macrosetae shorter than post macrosetae, covered by barbs along distal half. Urosternite I with 7+7 macrosetae; urosternites II-VII with 5+5 macrosetae; urosternite VIII with $2+2$ macrosetae; all urosternal macrosetae robust and large, covered by long barbs along distal threefourths to four-fifths. Apical, subapical and ventromedial setae with abundant long barbs.

SeCONDARY SEX CHARACTERS. Male urosternite I (Fig. 11) with up to 180 glandular $g_{l}$ setae arranged in up to five rows, with enlarged subcylindrical appendages each bearing up to 52 glandular $a_{1}$ setae. Female appendages slightly thinner, with up to 38 glandular $a_{1}$ setae.

\section{Phyletic affinities, habitat and distribution}

The modest subequal claws, including the posterior claw lacking a backward overhang, and the absence of lateral anterior macrosetae on the metanotum relate $P$. (P.) apollo sp. nov. to $P$. (P.) festae. Nonetheless the more abundant posterior urotergal macrosetae, with $6+6$ post on urotergites IV-VII, as well as $8+8$ and $10+10$ post on abdominal segments VIII-IX in $P$. (P.) apollo sp. nov., rather than $5+5$ on urotergites IV-VII, and 7+7 and 9+9 on abdominal segments VIII-IX in $P$. (P.) festae (Silvestri 1933a), separate the two species. Interestingly, the new species was collected in traps placed in MSS over the forest line 

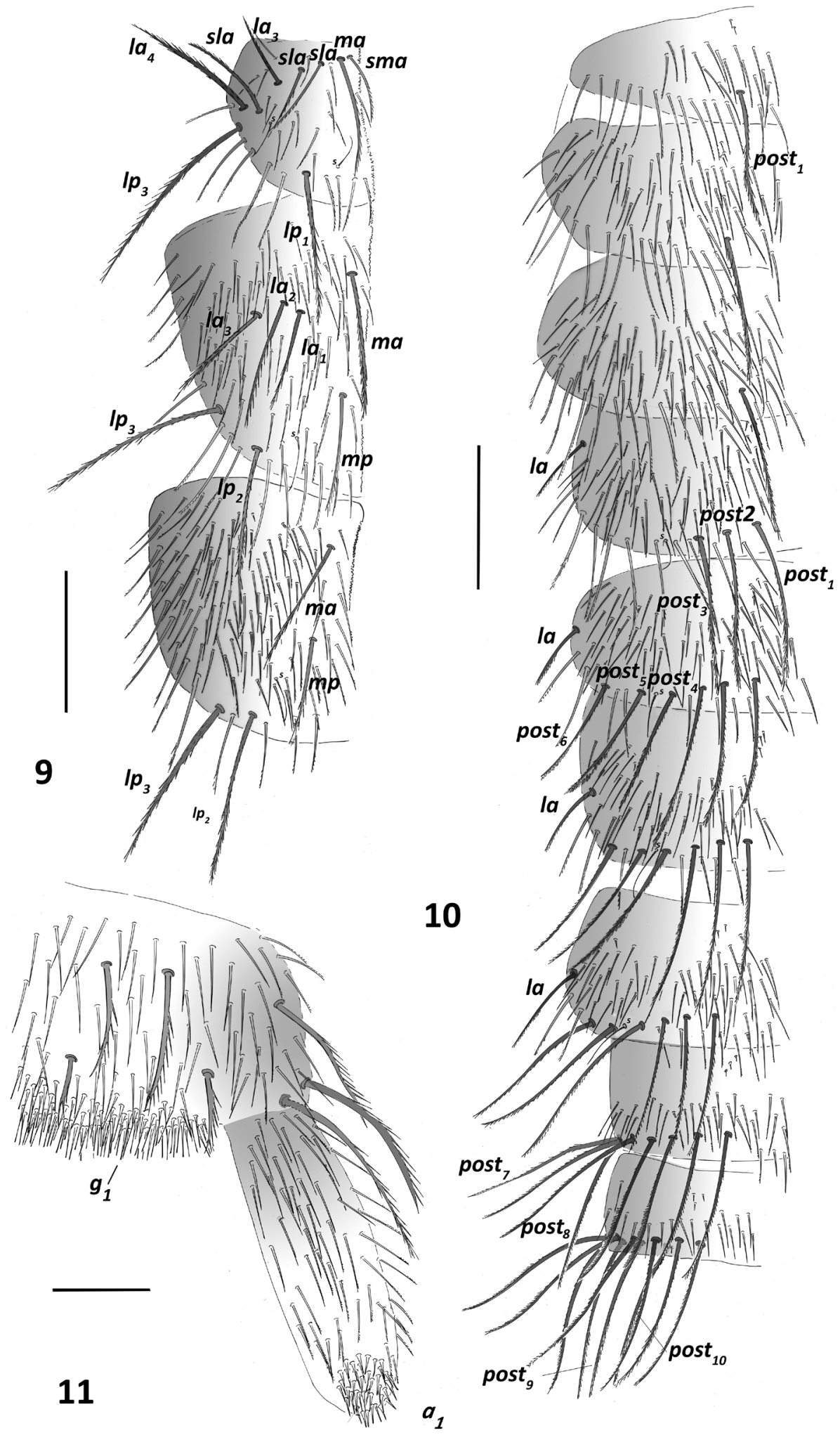

Figs 9-11. Plusiocampa (Plusiocampa) apollo Sendra, Giachino \& Vailati sp. nov. 9-10. Holotype, +, $4.8 \mathrm{~mm}$ long, from Viotìa, O. Pamassós, Greece (MZB 2019-1032). 9. Pronotum, mesonotum and metanotum ( $\mathrm{s}=$ setiform sensillum). 10. Urotergites I-VII and abdominal segment IX, right side ( $s=$ setiform sensillum). 11. Paratype, $\widehat{\partial}, 6.4 \mathrm{~mm}$ long, from the type locality (Coll. AS); urosternite I, left side. Scale bars: $9-10=30 \mu \mathrm{m} ; 11=10 \mu \mathrm{m}$. 
(type locality) or in Abies Mill. forest (all the other sites), at altitudes from 1075 to $1660 \mathrm{~m}$ a.s.1. This large range of hypogean habitats also occurs in $P$. ( $P$.) festae (see below).

Plusiocampa (Plusiocampa) arbanasiensis Bareth \& Condé, 2001

Plusiocampa (Plusiocampa) arbanisiensus Bareth \& Condé, 2001: 23, figs 7a-g, 8a-b [name emended to arbanasiensis].

Diagnosis (Bareth \& Condé 2001)

Non-troglomorphic species. Antennae with 23 and 26 antennomeres; five simple olfactory chemoreceptors in cupuliform organ; slightly protruding frontal process with slightly tubercular setae. Pronotum with $1+1 m a, 3+3 l a, 2+2$ lp macrosetae; mesonotum with $1+1 m a, 3+3 l a, 2+2 l p$ macrosetae; metanotum with $1+1 \mathrm{ma}, 1+1(2+1)$ la, $2+2$ lp macrosetae; long, barbed notal macrosetae; abundant barbed notal clothing setae. Two ventral tibial macrosetae; subequal claws (1.05-1.1) with large lateral crests, posterior claw with a small backward overhang. Urotergites I-II with $1+1$ post macrosetae; urotergite III with $2+2$ post macrosetae; urotergites IV-V with $1+1$ la, $5+5$ post macrosetae; urotergites VI-VII with $2+2(2+1)$ la, $5+5$ post macrosetae; urotergite VIII with $6+6$ post macrosetae; abdominal segment IX with $8+8$ post macrosetae; urosternite I with $7+7$, urosternites II-VII with $5+5$, urosternite VIII with $2+2$ macrosetae. Male with glandular $g_{1}$ setae, subcylindrical appendages with glandular $a_{1}$ setae; female appendages similar to those of male.

\section{Remarks}

The studied material allowed us to complete the above description. The complete antennae of a female from Jama $1 \mathrm{v}$ Kanjaducah show 23 antennomeres with five simple olfactory chemoreceptors within the cupuliform organ; it has a distal whorl of 8-11 gouge sensilla that are $25 \mu \mathrm{m}$ long. All specimens show a simple frontal process with non-tubercular setae; smooth subapical tarsal setae; abdominal segment IX with $8+8$ post macrosetae; urosternite I of male with a narrow area of up to 80 glandular $g_{1}$ setae arranged in two or three rows; subcylindrical appendages with up to 12 glandular $a_{1}$ setae; females with subcylindrical appendages as in male, with up to 9 glandular $a_{1}$ setae. Nevertheless, the large distance from the type locality casts serious doubts regarding the correct identification of this rare species.

\section{Habitat and distribution}

Hypogean species found in two geographically distant karst regions, the Lyashkata Peshtera Cave, Balkan Mountains in Bulgaria, and two caves in the Slovenian Dinaric Mountains.

\section{Plusiocampa (Plusiocampa) baetica Sendra, 2004}

Figs 12-23

Plusiocampa baetica Sendra in Sendra et al., 2004: 114, figs 1-4, tables 1-4.

Diagnosis (Sendra et al. 2004)

Troglomorphic species. Antennae with 39 antennomeres; 12 very complex olfactory chemoreceptors in a large cupuliform organ; protruding frontal process with tubercular setae. Pronotum with $1+1 \mathrm{ma}, 2+2$ $l a, 2+2$ lp macrosetae; mesonotum $1+1$ with $m a, 2+2 l p$ macrosetae; metanotum without macrosetae; short, barbed notal macrosetae except pronotal $l p$; sparse smooth clothing setae. Two ventral tibial macrosetae; slightly unequal claws (1.16) with large lateral crests, posterior claw with a short backward overhang. Urotergites V-VI with $1+1$ la, $1+1$ post macrosetae; urotergite VII with $1+1$ la, $2+2-3+3$ post macrosetae; urotergite VIII with 5+5-6+6 post macrosetae; abdominal segment IX with $8+8$ post macrosetae; urosternite I with $8+8$, urosternites II-VII with $5+5$, urosternite VIII with $2+2$ macrosetae. Male with a narrow area of glandular $g_{l}$ setae, with subcylindrical appendages similar to those of female, with glandular $a_{1}$ setae. 


\section{Remarks}

SEM observations have shown several taxonomical features to complete the original description (Sendra et al. 2004). Each olfactory chemoreceptor shows a spiral fold with a central cylindrical structure, all with a multiporous surface, all tightly open to the exterior through a small opening (Figs 12, 14-15), surrounded by tiny coniform sensilla (Figs 12-13) that are present in the whorl of thin gouge sensilla
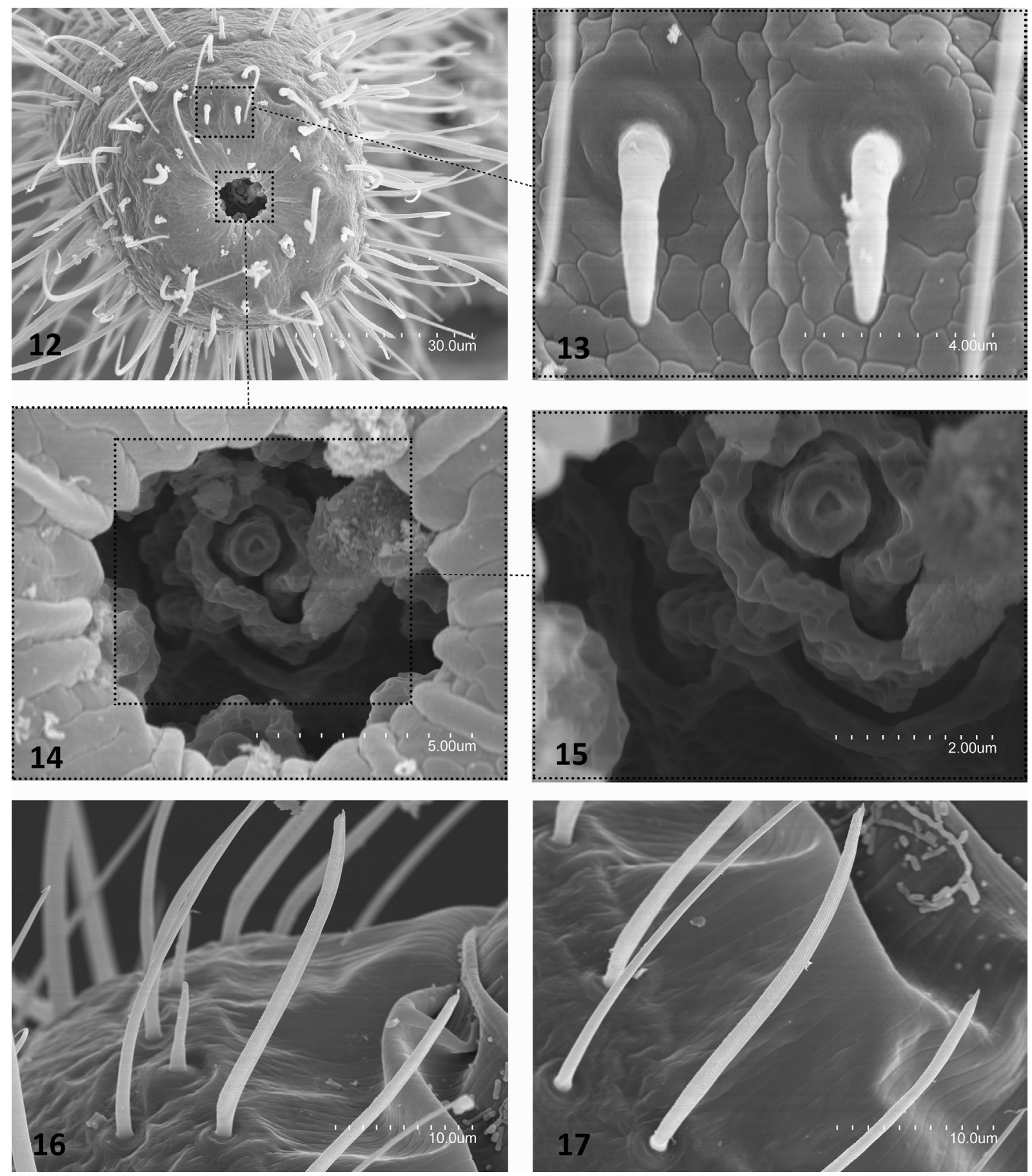

Figs 12-17. Plusiocampa (Plusiocampa) baetica Sendra, 2004, from Cueva de Nerja, Nerja, Málaga, Spain (Coll. AS). 12. Apical view of last antennomere. 13. Coniform sensilla of last antennomere. 14. Cupuliform organ. 15. Olfactory chemoreceptor. 16. Lateral side of medial antennomere. 17. Gouge sensilla. 
on each medial and distal antennomere (Figs 16-17). Tibia longer than femur and tarsus (Fig. 18). Pretarsus with subequal claws with large lateral crests, the claws carved by longitudinal ridges and a micro-tuberculated surface (Figs 20, 22-23). Lateral process smooth, with several thin basal barbs (Figs 22-23). Stylar setae with abundant barbs (Fig. 21). Male with subcylindrical appendages with only glandular $a_{1}$ setae and a narrow area of glandular $g_{1}$ seate (Fig. 19).
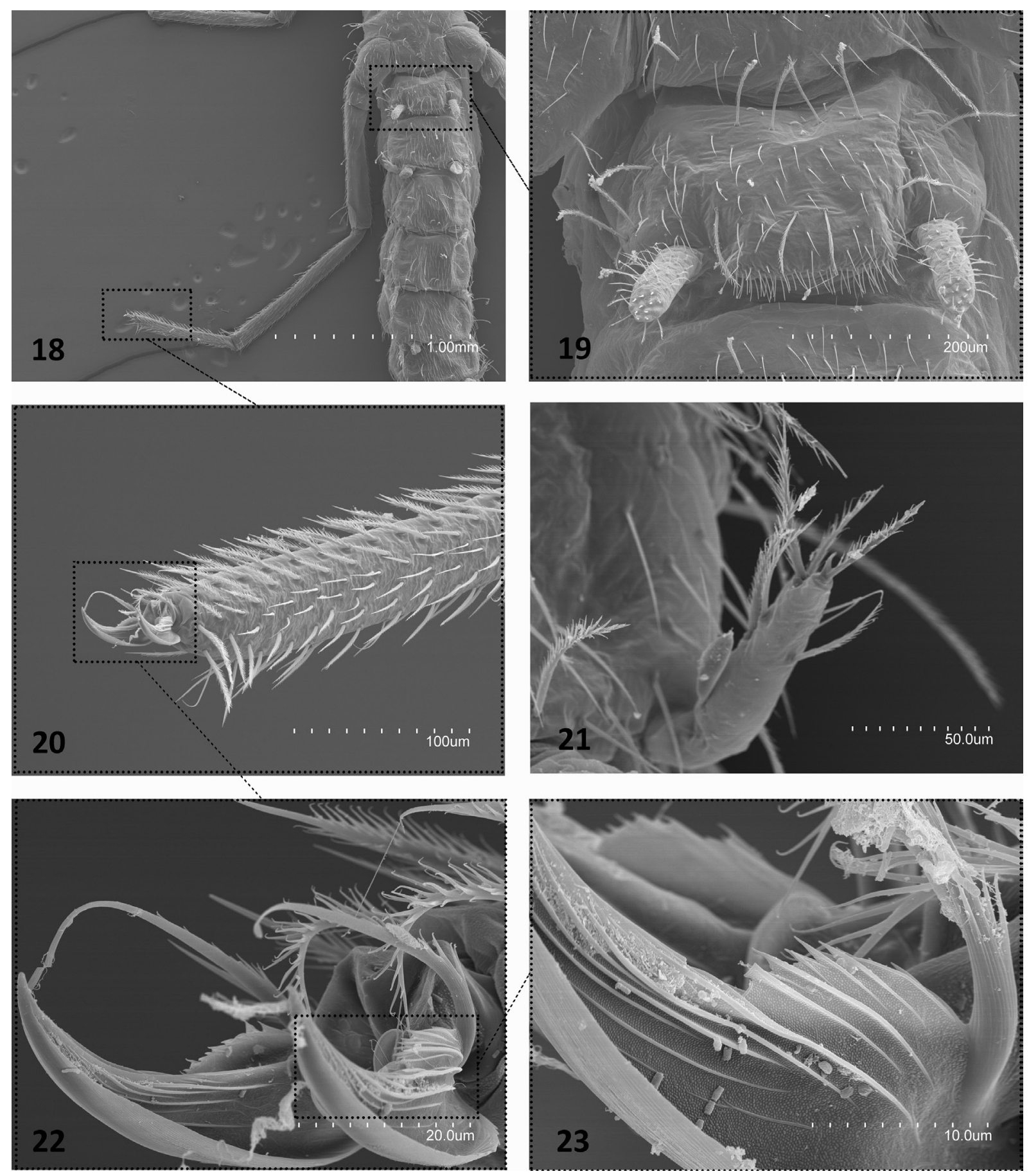

Figs 18-23. Plusiocampa (Plusiocampa) baetica Sendra, 2004, from Cueva de Nerja, Nerja, Málaga, Spain (Coll. AS). 18. Incomplete abdomen and thorax, ventral view, including metathoracic right leg. 19. Urosternite I, J. 20. Metatarsus of metathoracic leg. 21. Abdominal stylus. 22. Pretarsus of metathoracic leg, latero-anterior view. 23. Lateral anterior claw of metathoracic leg, detail. 
SENDRA A. et al., Euro-Mediterranean Plusiocampinae and tachycampoid diplurans

\section{Habitat and distribution}

Subterranean species known only from Nerja Cave, a touristic cave in the internal zone of the Baetic Mountain Range, southern Iberian Peninsula.

Plusiocampa (Plusiocampa) balsani Condé, 1947

Plusiocampa balsani Condé, 1947: 46, fig. 3f.

Campodea staphylinus Viré, 1897: 7, figs 1-2.

Diagnosis (Condé 1947b, 1948b; Bareth 2006)

Troglomorphic species. Antennae with 30-40 antennomeres; 12 complex olfactory chemoreceptors in cupuliform organ; protruding frontal process with tubercular setae. Pronotum with $1+1 \mathrm{ma}, 3+3$ $l a, 2+2 l p$ macrosetae; mesonotum with $1+1 \mathrm{ma}, 2+2 \mathrm{la}, 2+2 \mathrm{lp}$ macrosetae; metanotum $1+1 \mathrm{ma}$, 1+1-2+2 la, 2+2 lp macrosetae; large, long, barbed notal macrosetae; scarce barbed clothing setae. One or two ventral tibial macrosetae; unequal claws with large lateral crests, posterior claw with a backward overhang. Urotergites I-II with $1+1$ post macrosetae; urotergite III with $0+0-1+1$ la $1+1$ post macrosetae; urotergite IV with $1+1$ la, $2+2$ post macrosetae; urotergites $\mathrm{V}-\mathrm{VII}$ with $1+1$ la, 4+4 post macrosetae; urotergite VIII with $6+6$ post macrosetae; abdominal segment IX with $8+8$ post macrosetae; urosternite I with $7+7$, urosternites II-VII with $6+6$, urosternite VIII with $2+2$ macrosetae. Male with a narrow area of glandular $g_{1}$ setae, with subtrapezoidal appendages with glandular $a_{2}$ setae; female with subcylindrical appendages with glandular $a_{l}$ setae. Spermatozoid fascicles with a diameter of 55-60 $\mu \mathrm{m}$ and a width of $15 \mu \mathrm{m}$, its filament wheels with $2 \frac{1}{2}$ turns of $460 \mu \mathrm{m}$ long and 12-13 $\mu \mathrm{m}$ diameter filament.

\section{Habitat and distribution}

Subterranean species found in 49 caves around the Central Massif, France.

Plusiocampa (Plusiocampa) beroni Bareth \& Condé, 2001

Plusiocampa beroni Bareth \& Condé, 2001: 16, figs 3b, 4a-e.

Diagnosis (Bareth \& Condé 2001)

Slightly troglomorphic species. Antennae with 26-29 antennomeres; 5-6 complex olfactory chemoreceptors on cupuliform organ; non-protruding frontal process with non-tubercular setae. Pronotum with $1+1 m a, 3+3$ la, 2+2 lp macrosetae; mesonotum with $1+1 m a, 3+3$ la $, 2+2 l p, 1+1 m p$ macrosetae; metanotum with $1+1 m a, 1+1(2+1) l a, 2+2 l p, 1+1 m p$ macrosetae; long, barbed notal macrosetae; abundant notal clothing setae. Two ventral tibial macrosetae; unequal claws (1.30) with large lateral crests, posterior claw with a backward overhang. Urotergites I-II with 1+1 post macrosetae; urotergite III with $2+2$ post macrosetae (1+1 la $1+1$ post on one specimen from Novata Peştera, western Rhodope); urotergite IV with $1+1$ la $4+4-5+5$ post macrosetae; urotergite $\mathrm{V}$ with $1+1-2+2$ la, 5+5 post macrosetae; urotergites VI-VII with $2+2-3+3$ la, $5+5$ post macrosetae; urotergite VIII with $6+6$ post macrosetae; abdominal segment IX with $8+8$ post macrosetae; urosternite I with $7+7$, urosternites II-VII with $5+5$, urosternite VIII with $2+2$ macrosetae. Male with an area of glandular $g_{l}$ setae, subcylindrical appendages with glandular $a_{1}$ setae (adults from Gruffre Padez, Sofia with short, thick appendages with a large area of glandular $a_{l}$ setae); female with subcylindrical appendages with glandular $a_{l}$ setae. Spermatozoid fascicle wheels with 2 turns of $50 \mu \mathrm{m}$ long and $5 \mu \mathrm{m}$ diameter filament.

\section{Habitat and distribution}

Subterranean species found in six caves in different karst regions of the Bulgarian Balkan Mountains (= Stara Planina Mts). 


\section{Plusiocampa (Plusiocampa) bonadonai bonadonai Condé, 1948}

Plusiocampa bonadonai Condé, 1948c: 50, figs 2-3.

Diagnosis (Condé 1948c, 1949, 1950; Condé \& Poivre 1982; Bareth 2006)

Troglomorphic species. Antennae with 31-37 antennomeres; 7-8 complex olfactory chemoreceptors in cupuliform organ. Pronotum with $1+1 m a, 4+4 l a, 2+2 l p$ macrosetae; mesonotum with $1+1 m a$, $3+3 l a, 2+2 l p, 1+1 \mathrm{mp}$ macrosetae; metanotum with $1+1 \mathrm{ma}, 1+1 \mathrm{la}, 2+2 \mathrm{lp}, 1+1 \mathrm{mp}$ macrosetae; long, barbed notal macrosetae; sparse notal clothing seate with a few distal barbs. Two or three ventral tibial macrosetae; subequal claws (1.05) with large lateral crests, posterior claw with a small backward overhang. Urotergites I-III with $1+1$ post macrosetae; urotergites IV-VII with $1+1$ la, $5+5$ post macrosetae; urotergite VIII with $6+6$ post macrosetae; abdominal segment IX with $8+8$ post macrosetae; urosternite I with $7+7$, urosternites II-VII with $5+5$, urosternite VIII with $2+2$ macrosetae. Male with abundant glandular $g_{1}$ setae, subcylindrical appendages like female appendages, with glandular $a_{1}$ setae.

\section{Habitat and distribution}

Subterranean species found in 11 caves and at one edaphic site in the Île Saint-Honorat caves around the Western Alps, in the mountain reliefs near the Mediterranean coast in the Provence Alps, France.

\section{Plusiocampa (Plusiocampa) bonadonai lanzai Condé, 1961}

Plusiocampa bonadonai lanzai Condé, 1961: 399.

Diagnosis differential against the type form (Condé 1961; Condé \& Poivre 1982)

Troglomorphic subspecies. Antennae with 27-33 antennomeres. Urotergite III with 2+2 post macrosetae. No adult males have been observed, and the young males from Valais do not have glandular $g_{1}$ setae, without glandular $a_{2}$ setae.

\section{Habitat and distribution}

Subterranean subspecies found in a cave of Valais (Switzerland) as well as in two caves in Brescia and Toscana (Italy), around the Western Alps.

Plusiocampa (Plusiocampa) bonadonai pavani Condé \& Poivre, 1982

Plusiocampa bonadonai pavani Condé \& Poivre, 1981: 171.

Differential diagnosis against the type form (Condé \& Poivre 1982)

Troglomorphic subspecies. Antennae with 31-36 antennomeres; urosternite VIII with 7+7 post macrosetae.

\section{Habitat and distribution}

Subterranean subspecies found in 13 caves around the Western Alps.

Plusiocampa (Plusiocampa) bonneti bonneti Condé, 1948

Figs 24-29

Plusiocampa pouadensis bonneti Condé, 1948c: 54, fig. 4b.

Plusiocampa bonneti escolai Sendra, 1985: 123, fig. 2 b.

Diagnosis (Condé 1948c; Sendra 1985; Bareth \& Condé 1996; Sendra \& Escolà 2004; Bareth 2006)

Troglomorphic species. Antennae with 28-40 antennomeres; nine to ten complex olfactory chemoreceptors in cupuliform organ; protruding frontal process with tubercular setae. Pronotum with $1+1 m a, 3+3 l a, 2+2$ lp macrosetae; mesonotum with $1+1 m a, 3+3 l a, 2+2 l p$ macrosetae; metanotum 
with $1+1 m a, 2+2 l a, 2+2 l p$ macrosetae; long, barbed notal macrosetae; abundant notal clothing setae with distal barbs. Two ventral tibial macrosetae; slightly unequal claws (1.1-1.2) with large lateral crests, posterior claw with a backward overhang. Urotergites I-III with $1+1$ post macrosetae; urotergite IV with $1+1$ la, $5+5$ post macrosetae; urotergite $\mathrm{V}$ with $1+1-2+2$ la, 5+5 post macrosetae; urotergites VI-VII with $2+2$ la, $5+5$ post macrosetae; urotergite VIII with $6+6$ post macrosetae; abdominal segment
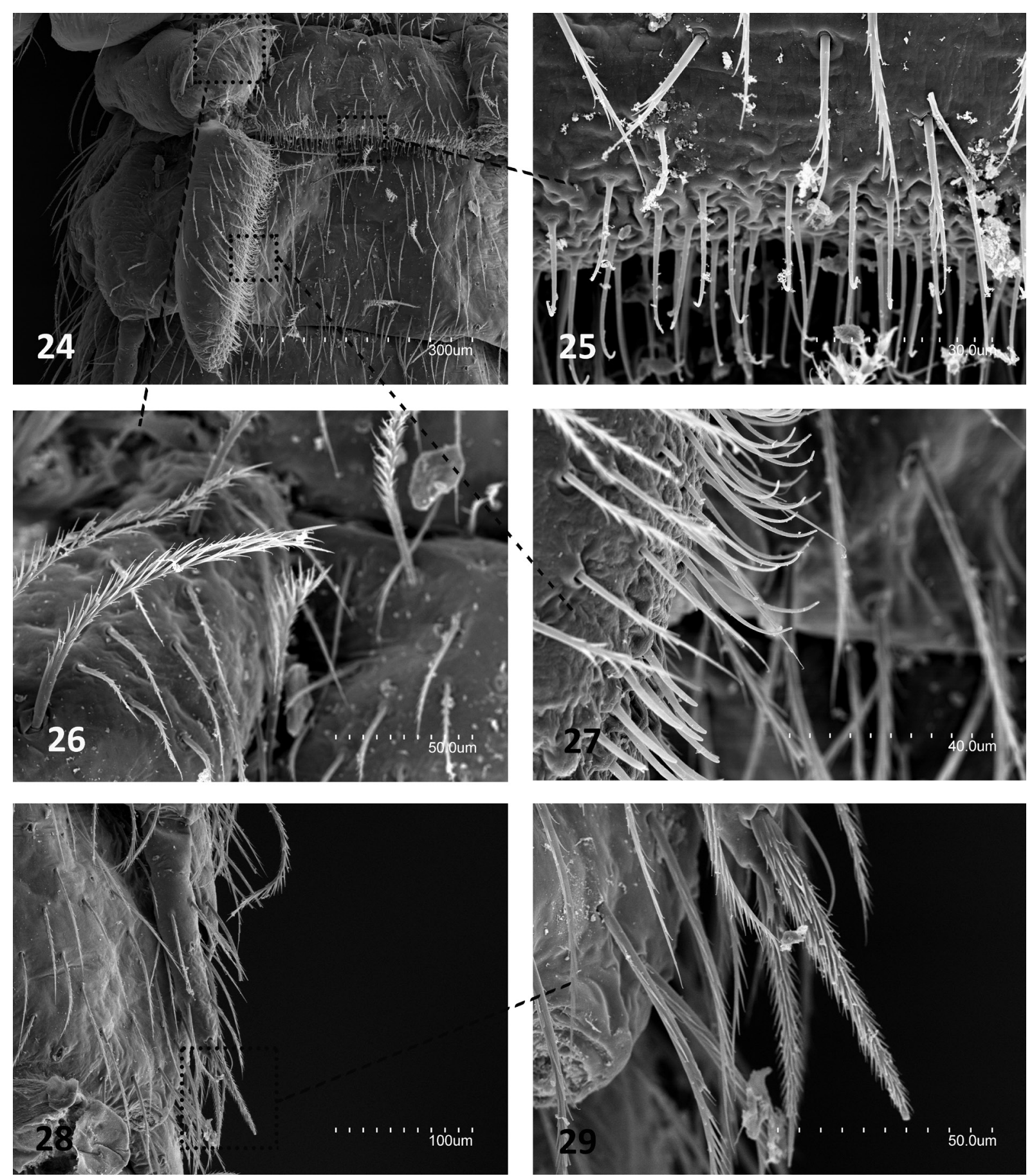

Figs 24-29. Plusiocampa (Plusiocampa) boneti boneti Condé, 1948, đ̊̄, from Cova Mora, Huesca, Spain (Coll. AS). 24. Urosternite I, right side. 25. Urosternite I, detail of glandular $g_{1}$-setae. 26. Macrosetae of urosternite I. 27. Appendage of urosternite I, glandular $a_{1}$ and $a_{2}$ setae. 28. Stylus of left urosternite VI. 29. Distal stylus of left urosternite VI, detail. 
IX with $8+8$ post macrosetae; urosternite I with $7+7$, urosternites II-VII with $5+5$, urosternite VIII with $2+2$ macrosetae. Male with a large area of glandular $g_{l}$ setae, subtrapezoidal appendages with glandular $a_{2}$ setae; female with subcylindrical appendages with glandular $a_{1}$ setae.

\section{Habitat and distribution}

Subterranean species found in three caves in the southern reliefs of France, west of the Rhône River, and in 34 caves distributed from the Central Pyrenees to the Pre-Pyrenees without reaching the Ebro Basin.

Plusiocampa (Plusiocampa) bonneti condei Sendra \& Escolà, 2004

Figs 30-41

Plusiocampa bonneti condei Sendra \& Escolà, 2004: 892.

Plusiocampa pouadensis bonneti - Condé 1951: 61.

Differential diagnosis against the type form (Sendra 1985; Sendra \& Escolà 2004)

Antennae with 30-43 antennomeres; eight to nine complex olfactory chemoreceptors in cupuliform organ; protruding frontal process with slightly tubercular setae. Spermatozoid fascicle wheels with $2-2 \frac{1}{2}$ turns of $300-400 \mu \mathrm{m}$ long and $7 \mu \mathrm{m}$ diameter filament.

\section{Remarks (Figs 24-35)}

One male of P. (P.) bonneti bonneti from Cova Mora (San Juan de la Peña, Huesca, Spain) and six specimens of $P$. (P.) bonneti condei from Cova Toll (Moià, Barcelona, Spain) (see Table S2 in Supplementary Material) were used for SEM to remark on some features that are difficult to observe under the optical microscope. In $P$. (P.) bonneti bonneti, the first urosternite shows very long subtrapezoidal appendages with a large area of glandular $a_{2}$ setae and a large area of glandular $g_{1}$ setae, with the surface covered by barbed clothing setae and well-barbed macrosetae (Figs 24-27). In $P$. (P.) bonneti condei, the epicuticle varies from completely smooth to gently reticulate (Fig. 35); antennomeres with a whorl of gouge sensilla, 16-18 $\mu \mathrm{m}$ long (Figs 31, 33). Olfactory chemoreceptors with a central column unfolded in several layers with a reticulate surface covered by pores (Fig. 30). Protruding frontal process with slightly tubercular macrosetae and setae (Figs 32,34). Claws with large lateral crest with ventral longitudinal grooves separated by reticulate surfaces (Figs 36-39). Stylar setae totally covered by short, thin barbs (Fig. 40). Large eversible vesicles (Fig. 41).

\section{Habitat and distribution}

Subterranean subspecies found in 35 caves in the Eastern Pyrenees and the northern part of the Catalan Mediterranean Mountain System.

Plusiocampa (Plusiocampa) bonneti deharvengi Bareth \& Condé, 1996

Plusicampa bonneti deharvengi Bareth \& Condé, 1996: 128, figs 1-2, table 1.

Differential diagnosis against the type form (Bareth \& Condé 1996)

Antennae with 34-38 antennomeres; six to seven simple olfactory chemoreceptors in cupuliform organ; slight protruding frontal process with a few anterior tubercular setae; abundant barbed notal clothing setae. One ventral tibial macroseta. Unequal claws with large lateral crests, posterior claw with a backwards overhang. Urotergites IV-VII with $1+1$ la, 5+5 post macrosetae. Male with an area of glandular $g_{1}$ setae; subtriangular appendages with glandular $a_{2}$ setae. Spermatozoid fascicle wheels with $1 \frac{1}{2}-2$ turns of $8 \mu \mathrm{m}$ diameter filament.

\section{Habitat and distribution}

Subterranean subspecies found in two caves in the northern part of the Eastern Pyrenees. 


\section{Plusiocampa (Plusiocampa) breviantennata Loksa, 1960}

Plusiocampa breviantennata Loksa, 1960: 258, figs 2-9.

Diagnosis (Loksa 1960)

Non-troglomorphic species. Antennae with 19-20 doliiform antennomeres. Pronotum with $1+1 \mathrm{ma}, 2+2$ $l a, 2+2$ lp macrosetae; mesonotum with $1+1 \mathrm{ma}, 3+3$ la, $2+2$ lp macrosetae; metanotum with $1+1 \mathrm{ma}, 1+1$
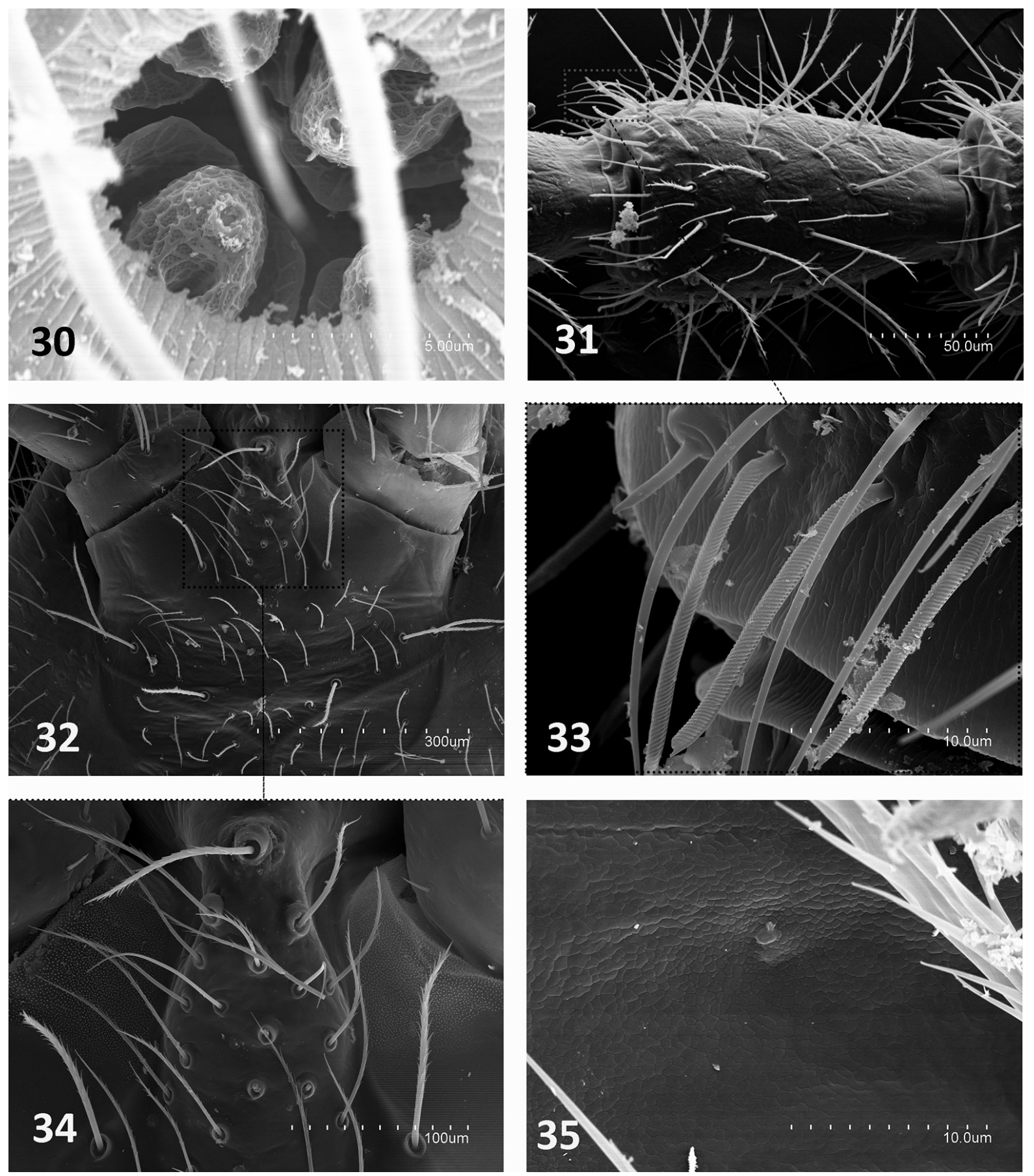

Figs 30-35. Plusiocampa (Plusiocampa) bonneti condei Sendra \& Escolà, 2004, from Cova del Toll, Moià, Barcelona, Spain (Coll. AS). 30. Cupuliform organ. 31. Medial antennomere. 32. Frontal process. 33. Lateral distal view of medial antennomere, with gouge and coniform sensilla 34. Protruding frontal process. 35. Surface of metanotum. 
$l a, 2+2$ lp macrosetae; thin notal macrosetae; sparse notal clothing setae. Two ventral tibial macrosetae. Urotergites I-II with $1+1$ post macrosetae; urotergite III with $3+3$ post macrosetae; urotergites IV-VII with $4+4$ post macrosetae; la macrosetae not mentioned in original description.
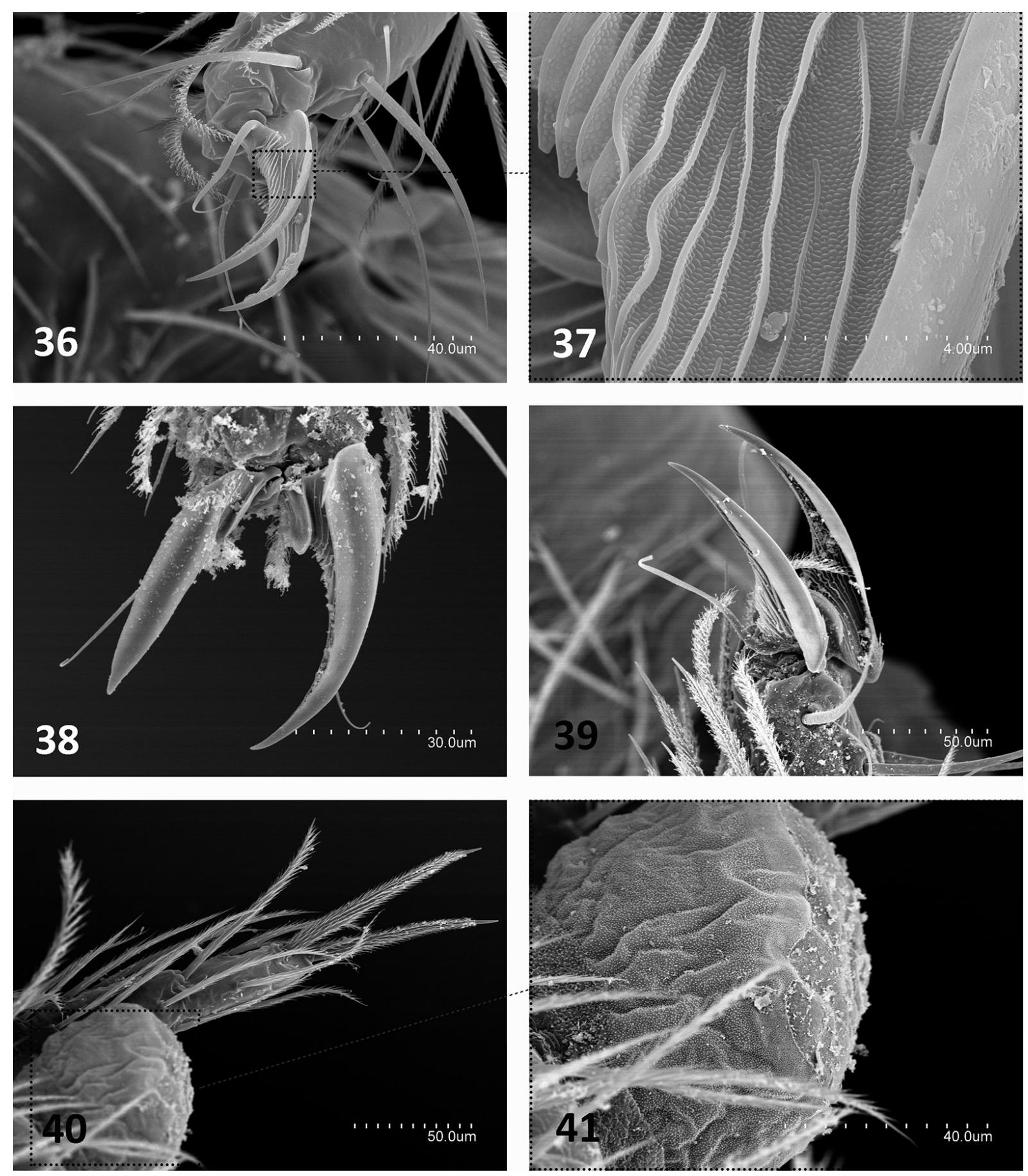

Figs 36-41. Plusiocampa (Plusiocampa) bonneti condei Sendra \& Escolà, 2004, from Cova del Toll, Moià, Barcelona, Spain (Coll. AS). 36. Lateral posterior pretarsus of metathoracic leg. 37. Lateral detail of posterior claw of metathoracic leg. 38. Frontal view of pretarsus of metathoracic leg. 39. Lateral anterior view of pretarsus. 40. Stylus and abdominal eversible vesicle of urosternite. 41. Detail of abdominal eversible vesicle. 


\section{Habitat and distribution}

Hypogean species, only found in Lóczy Cave, Balatonfüred, in the Balaton Uplands, southern Transdanubian Mountains, Hungary.

Plusiocampa (Plusiocampa) breuili Condé, 1955

Plusiocampa breuili Condé, 1955b: 125, figs 2, 3a-c.

Diagnosis (Condé 1955b; Condé \& Sendra 1989; Sendra et al. 2004)

Troglomorphic species. Antennae with 30 and 32 antennomeres; 21 complex olfactory chemoreceptors in cupuliform organ; protruding frontal process with non-tubercular setae. Pronotum with $1+1 \mathrm{ma}, 2+2$ $l a, 2+2 l p$ macrosetae; mesonotum with $1+1 \mathrm{ma}, 3+3 \mathrm{la}, 2+2 \mathrm{lp}, 1+1 \mathrm{mp}$ macrosetae; metanotum with $1+1 \mathrm{ma}, 1+1 \mathrm{la}, 2+2 \mathrm{lp}, 1+1 \mathrm{mp}$ macrosetae; long, barbed notal macrosetae, sparse notal clothing setae. 3 or 4 ventral tibial macrosetae (ratio of femur/tibia 0.66); subequal claws (1.1) with large lateral crests, posterior claw with a small backward overhang. Urotergites I-II with $1+1$ post macrosetae; urotergite III with $0+0-1+1$ la, $1+1$ post macrosetae; urotergite IV with $2+2(2+1)$ la, $5+5$ post macrosetae; urotergites V-VII with $2+2$ la, $5+5$ post macrosetae; urotergite VIII with $6+6$ post macrosetae; abdominal segment IX with $8+8$ post macrosetae; urosternite I with $8+8$, urosternites II-VII with $5+5$, urosternite VIII with $2+2$ macrosetae. Male with an area of glandular $g_{1}$ setae, subcylindrical appendages with glandular $a_{1}$ setae; female with subcylindrical appendages with glandular $a_{1}$ setae.

\section{Plusiocampa (Plusiocampa) aff. breuili Condé, 1955}

\section{Differential diagnosis against the type form (Sendra et al. 2004)}

Frontal process with tubercular setae and 1+1 la macrosetae on urotergites VI-VII.

\section{Habitat and distribution}

Subterranean species inhabiting two caves in Eivissa and four caves in Formentera, two of the Balearic Islands. Plusiocampa (P.) aff. breuili is only known from a cave in the eastern Baetic Mountains, southeastern Iberian Peninsula.

\section{Plusiocampa (Plusiocampa) bulgarica Silvestri, 1931}

Figs 42-43

Plusiocampa bulgarica Silvestri, 1931b: 103, figs vi-viii.

Diagnosis (Silvestri 1931b; Bareth \& Condé 2001)

Troglomorphic species. Antennae with 24-30 antennomeres; 10 complex olfactory chemoreceptors in cupuliform organ; protruding frontal process with tubercular setae. Pronotum with $1+1 \mathrm{ma}, 4+4 \mathrm{la}, 2+2$ $l p$ macrosetae; mesonotum with $1+1 \mathrm{ma}, 3+3 \mathrm{la}, 2+2 \mathrm{lp}, 1+1 \mathrm{mp}$ macrosetae; metanotum with $1+1 \mathrm{ma}$, $2+2 l a, 2+2 l p, 1+1 \mathrm{mp}$ macrosetae; long, barbed notal macrosetae; a few long, distally barbed notal clothing setae. Two or three ventral tibial macrosetae; unequal claws (1.30) with large lateral crests, posterior claw with a backward overhang. Urotergites I-II with $1+1$ post macrosetae; urotergite III with $0+0-1+1$ la, $1+1-2+2$ post macrosetae; urotergite IV with $1+1$ la, $5+5$ post macrosetae; urotergite $\mathrm{V}$ with $2+2$ la, $5+5$ post macrosetae; urotergites VI-VII with $3+3$ la, 5+5 post macrosetae; urotergite VIII with $6+6$ post macrosetae; abdominal segment IX with $8+8$ post macrosetae; urosternite I with $7+7$, urosternites II-VII with $5+5$, urosternite VIII with $2+2$ macrosetae. Male with a large area of glandular $g_{1}$ setae and slightly enlarged appendages with glandular $a_{1}$ setae; female with subcylindrical appendages with glandular $a_{1}$ setae. 


\section{Remarks}

The study of 38 specimens collected from two new caves (see Table S2 in Supplementary Material) allowed the addition of information to the diagnosis, including the observation of the pretarsal structures (Figs 42-43).

\section{Habitat and distribution}

Subterranean species found in 16 caves in the Balkan and Rhodope Mountains, Bulgaria.

\section{Plusiocampa (Plusiocampa) caprai Condé, 1950}

Plusiocampa caprai Condé, 1950: 1, figs a-e.

\section{Diagnosis (Condé 1950, 1954a; Christian et al. 1996)}

Slightly troglomorphic species. Antennae with 28-30 antennomeres. Pronotum with $1+1 \mathrm{ma}, 3+3 \mathrm{la}$, $2+2$ lp macrosetae; mesonotum with $1+1 \mathrm{ma}, 3+3 \mathrm{la}, 2+2 \mathrm{lp}, 1+1 \mathrm{mp}$ macrosetae; metanotum with 1+1 $m a, 1+1 l a, 2+2 l p, 1+1 \mathrm{mp}$ macrosetae; long, barbed notal macrosetae; abundant notal clothing setae, either smooth or with a few thin barbs. Three ventral tibial macrosetae; unequal claws with large lateral crests, posterior claw with a backward overhang. Urotergites I-II with 1+1 post macrosetae; urotergite III with $2+2$ post macrosetae; urotergite IV with $1+1$ la, $5+5(4+4)$ post macrosetae; urotergite $\mathrm{V}$ with $2+2(1+1)$ la, $5+5$ post macrosetae; urotergites VI-VII with $2+2$ la, $5+5$ post macrosetae; urotergite VIII with $6+6$ post macrosetae; abdominal segment IX with $8+8$ post macrosetae. Urosternite I with $7+7$, urosternites II-VII with $5+5$, urosternite VIII with $2+2$ macrosetae. Male without glandular $g_{I}$ setae, slightly enlarged subcylindrical appendages with $a_{1}$ glandular setae; female with subcylindrical appendages with $a_{1}$ glandular setae.

\section{Remarks}

One male and one female of $P$. (P.) caprai from Babja jama (Slovenia) have been studied. However, two females collected from an MSS habitat in Corinthia (Peloponnese Peninsula) (see Table S2 in Supplementary Material) appear to be very closely related to $P$. (P.) caprai, although the substantial geographical distance between these two areas and the observation of only females cast doubts on this specific attribution. Furthermore, all antennae and cerci are broken. The frontal process shows a protrusion and bears tubercular setae.
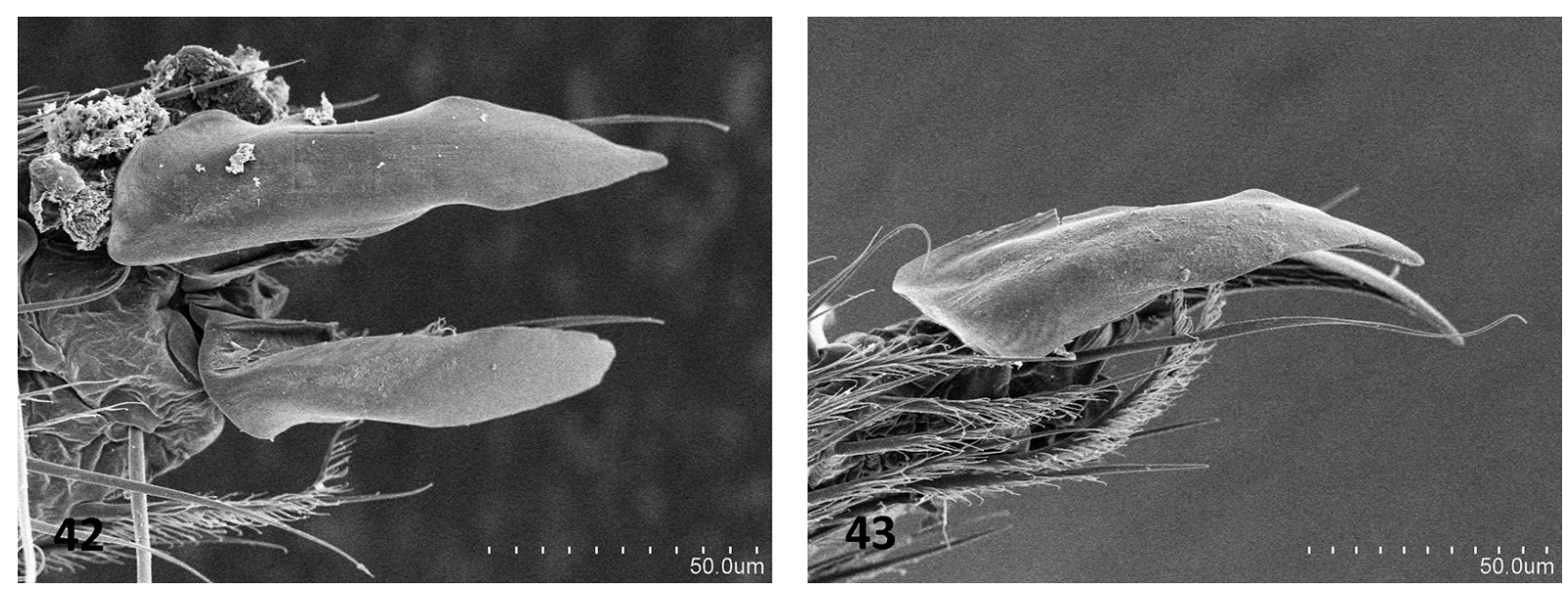

Figs 42-43. Plusiocampa (Plusiocampa) bulgarica Silvestri, 1931, from Sbrikovata Cave, Pamporovo, Bulgaria (Coll. AS). 42. Pretarsus, dorsal view. 43. Pretarsus, latero-posterior view. 


\section{Habitat and distribution}

Hypogean species inhabiting subterranean and soil habitats, found in six caves, one mine and two soil and MSS habitats in the Austrian, Italian, Slovenian and Swiss Alps.

Plusiocampa (Plusiocampa) chiosensis Sendra \& Gasparo sp. nov. urn:Isid:zoobank.org:act:B3F3B66C-8C7C-48BF-A841-EAD3DF711C47

Figs 44-46; Tables 3-4

\section{Etymology}

The name 'chiosensis' is proposed based on the island of Chios, where it occurs in its deep subterranean habitat.

\section{Material examined}

\section{Holotype}

GREECE • ; Chios Island, Sykias; 10 Jun. 2006; Fulvio Gasparo leg.; MZB 2019-1030.

\section{Paratypes}

GREECE $\bullet 2 \precsim \widehat{\jmath}$; same collection data as for holotype; Coll. AS.

\section{Description}

Body. Body length 4.4 and $4.9 \mathrm{~mm}$ (males, paratypes) and $7.8 \mathrm{~mm}$ (female, holotype). Epicuticle smooth under optical microscope; body with sparse thin, long clothing, covered or not by a few thin distal barbs.

HEAD. Holotype with two intact antennae of 54 antennomeres, $14.8 \mathrm{~mm}$ long. Small coniform sensillum of third antennomere located in ventral position between $c$ and $d$ macrosetae. Central antennomeres $3.8 \times$ as long as wide, apical anntenomere $3.6 \times$ as long as wide. Small cupuliform organ occupying $1 / 9$ of total length of apical antennomere, with 6-7 complex olfactory chemoreceptors. Thin and long gouge sensilla (44-47 $\mu \mathrm{m}$ long) in a single distal whorl of 10-13 sensilla on each medial and distal antennomere. Frontal process developed, with tubercular setae and macrosetae with thin barbs. Three macrosetae along line of insertion of antennae poorly differentiated, only anterior one with 1-2 thin apical barbs; $x$ setae longer than these macrosetae, with a couple of thin apical barbs (Fig. 44). Suboval labial palps with latero-external sensillum larger than sensillum of third antennomere, with two guard setae, up to 12 setae on anterior border and up to 130 neuroglandular setae.

Thorax. Distribution of thoracic macrosetae: pronotum with $1+1 m a, 4+4-3+3 l a_{1,2,3,4}, 2+2 l p_{2,3}$ (additionally in the three type specimens, $1+1$ extra $m a$ near the sagittal plane); mesonotum with $1+1$ $m a, 1+1(0+1) l a_{2}, 2+2 l p_{2,3}, 1+1 m p$; metanotum with $1+1 m a, 1+1 l p_{2}$ and $1+1,0+1$ or $0+0 m p$. All notal macrosetae long, thin, covered by very thin barbs along distal third up to half; marginal setae

Table 3. Plusiocampa (Plusiocampa) chiosensis Sendra \& Gasparo sp. nov. Length of the body, metathoracic legs and their segments: trochanter, femur, tibia and tarsus (measurements in $\mathrm{mm}$ ).

\begin{tabular}{ccccccc}
\hline \multirow{2}{*}{ Specimen } & \multirow{2}{*}{ Body length } & \multicolumn{5}{c}{ Metathoracic leg } \\
\cline { 3 - 7 } & & Trochanter & Femur & Tibia & Tarsus & Total length \\
\hline O, paratype (Coll. AS) & 4.4 & 0.20 & 0.9 & 1.10 & 1.01 & 3.20 \\
今, paratype (Coll. AS) & 4.9 & 0.22 & 1.04 & 1.31 & 1.14 & 3.71 \\
क, holotype (MZB 2019-1030) & 7.8 & 0.40 & 1.60 & 2.20 & 1.60 & 5.80 \\
\hline
\end{tabular}



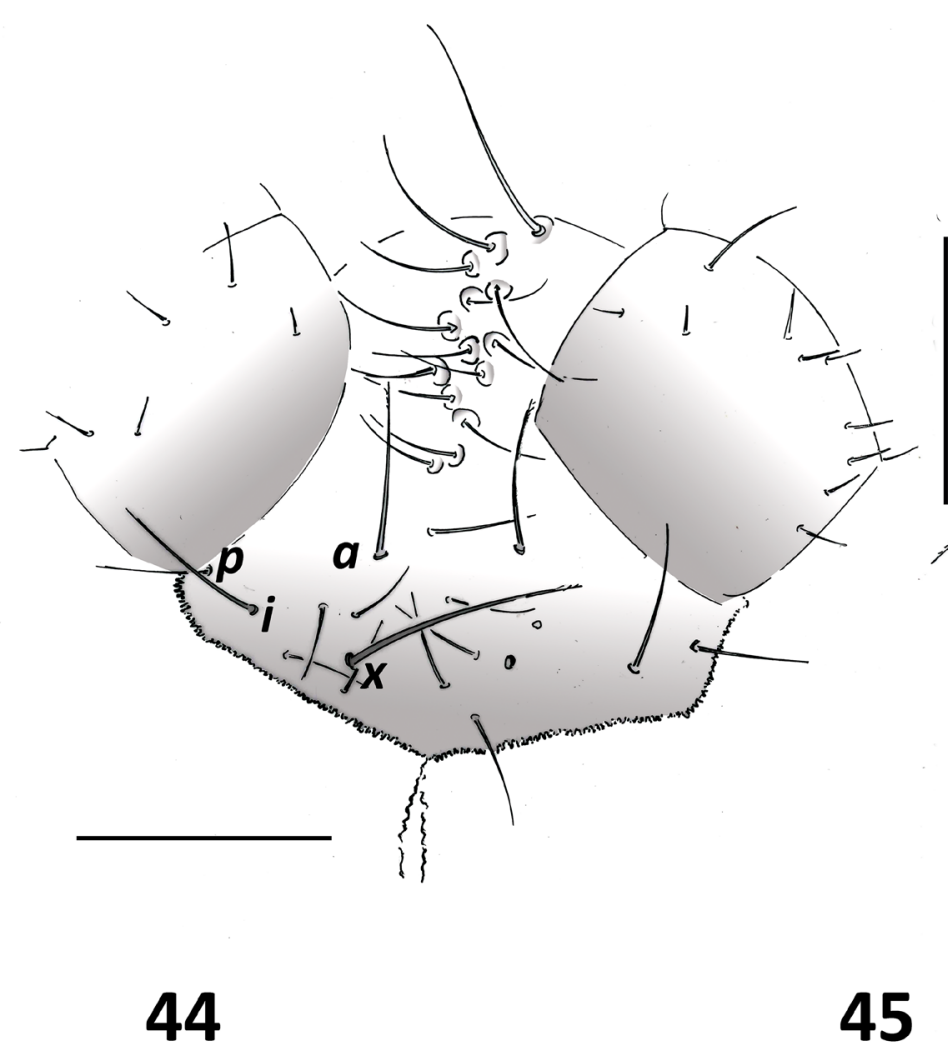

45
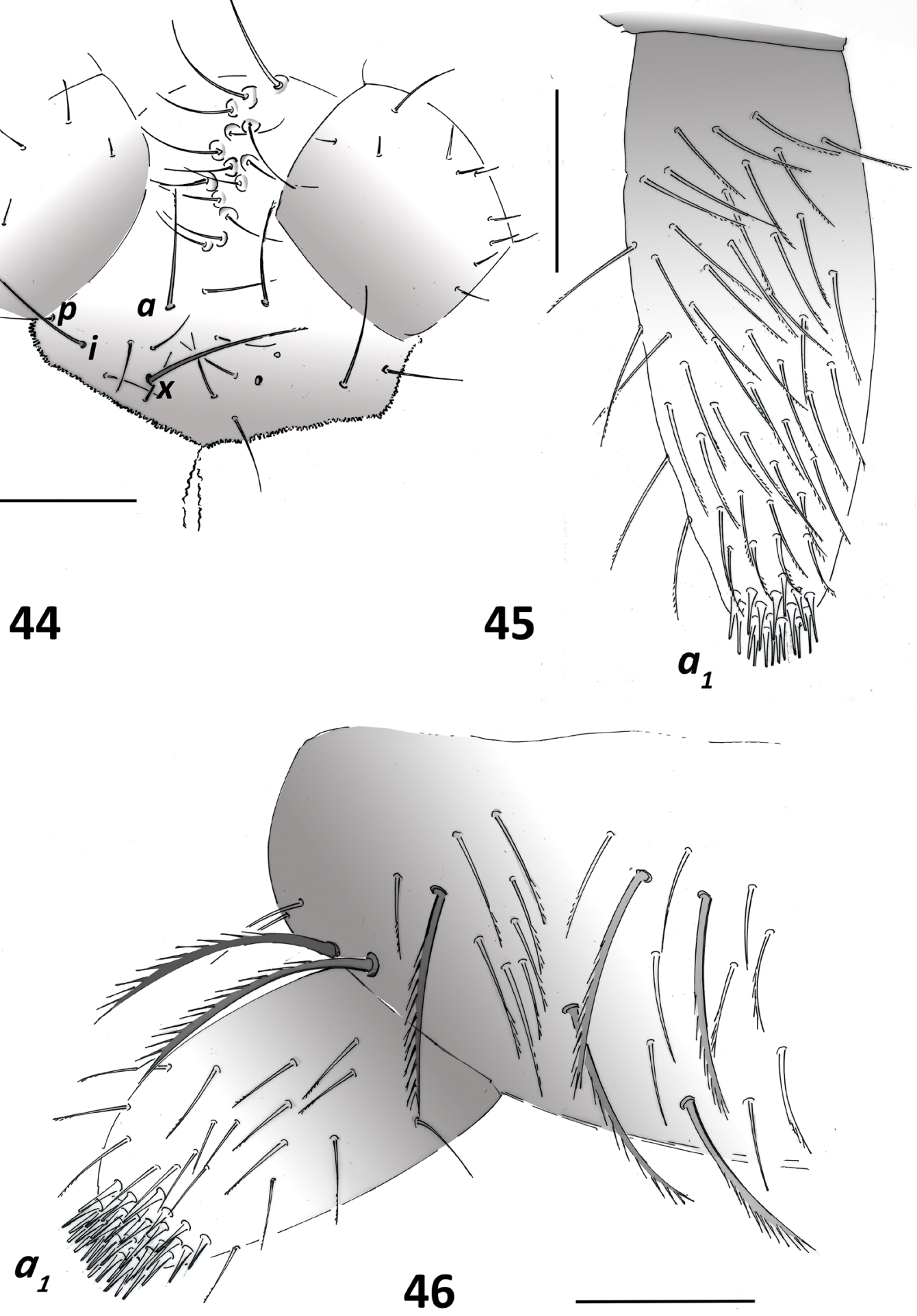

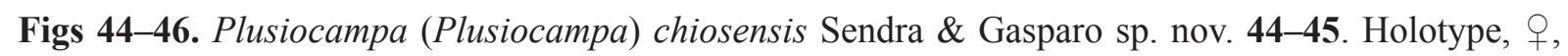
$7 \mathrm{~mm}$ long, from Spilaio Sykias Cave, Chios Island (MZB 2019-1930). 44. Frontal process (a, $i$ and $p$ macrosetae of antennal insertion and $x$ setae). 45. Right appendage of urosternite I. 46. Paratype, $\hat{o}$, $4.9 \mathrm{~mm}$ long, from type locality (Coll. AS); urosternite I, right side. Scale bars: $44=0.2 \mathrm{~mm}$; $45-46=$ $0.1 \mathrm{~mm}$. 
SENDRA A. et al., Euro-Mediterranean Plusiocampinae and tachycampoid diplurans

Table 4. Plusiocampa (Plusiocampa) chiosensis Sendra \& Gasparo sp. nov. Length of one cercus in the holotype (MZB 2019-1030) (measurments in mm).

\begin{tabular}{cccccccccc}
\hline Base & $\mathbf{1}^{\text {st }}$ & $\mathbf{2}^{\text {nd }}$ & $\mathbf{3}^{\text {rd }}$ & $\mathbf{4}^{\text {th }}$ & $\mathbf{5}^{\text {th }}$ & $\mathbf{6}^{\text {th }}$ & ${7^{\text {th }}}^{\text {th }}$ & $\mathbf{8}^{\text {Total }}$ \\
\hline 2.80 & 1.10 & 1.45 & 1.65 & 2.05 & 2.35 & 2.80 & 2.70 & 2.80 & 19.70 \\
\hline
\end{tabular}

longer than clothing setae, covered by thin barbs along distal half up to two thirds; spare clothing setae, with 14, 21 and 23 clothing setae on each heminotum of pronotum, mesonotum and metanotum, respectively (holotype). Legs elongated, metathoracic legs overpassing end of abdomen in middle of tibia; measurements as in Table 3. Femora II-III with one long dorsal macroseta and one longer ventral macroseta. Tibiae I-III with two ventral macrosetae surrounded all along by thin, short barbs. Calcars surrounded from base to tip by thin, short barbs. Dorsal and lateral subapical tarsal setae completely covered by thin barbs almost from base and almost to tip. Subequal claws (posterior claw 1.0-1.05× as long as anterior claw); posterior claw with a small backward overhang; lateral crests well developed, noticeably ridged on ventral side. Pretarsal lateral process setiform, with plenty of very short proximal barbs.

ABdomen. Distribution of abdominal macrosetae on tergites: $1+1$ post $_{1}$ on I-III; $1+1$ la, $2+2 l p_{l, 2}$ on IV; $1+1$ la, $5+5$ post $_{1-5}$ on V-VII, 8+8 post on VIII; 11+11 (11+12) post on abdominal segment IX. All post urotergal macrosetae thick, long, covered by thin barbs along distal four-fifths; la urotergal macrosetae shorter than post macrosetae, covered by barbs along distal half. Urosternite I with 7+7, urosternites IIVII with 5+5, urosternite VIII with $2+2$ macrosetae; all urosternal macrosetae robust and large, covered by long barbs along distal half up to four-fifths. Apical subapical and ventro-medial setae completely surrounded by short abundant barbs.

CERCI. One complete cercus in holotype with eight articles in addition to basal article, $19.70 \mathrm{~mm}$ long (Table 4), $2.53 \mathrm{~mm}$ longer than body length; articles show whorls of long macrosetae covered by thin barbs along distal two-thirds, combined with whorls of smooth, thin setae shorter than macrosetae.

SeCondary seX Characters. Female urosternite I (Fig. 45) with enlarged subcylindrical appendages, each bearing up to 16 glandular $a_{1}$ setae in a distal area. Male urosternite I (Fig. 46) without glandular $g_{1}$ setae, with moderated large subcylindrical appendages thicker than those of female, each bearing up to 33 glandular $a_{1}$ setae.

\section{Phyletic affinities, habitat and distribution}

Although $P$. (P.) chiosensis sp. nov. has medial posterior macrosetae on the mesonotum and metanotum (sometimes absent in one or two heminota), as do many previously described species of Plusiocampa s. str., a similar reduction in the number of lateral anterior and lateral posterior macrosetae on the mesonotum and metanotum is present in another troglomorphic species, $P$. $(P$.) glagra from continental Greece (Condé 1984a). Plusiocampa (P.) chiosensis sp. nov. also shares a couple of noticeable taxonomical features with $P$. (P.) glabra in their subequal claws and the number of urosternal macrosetae. Nevertheless, the presence of $1+1$ lateral anterior macrosetae on the mesonotum, the more abundant macrosetae on all urotergites, including the eighth abdominal segment, and the absence of glandular $g_{1}$ setae in males in $P$. (P.) chiosensis sp. nov. distinguish it from $P$. (P.) glabra.

Plusiocampa (P.) chiosensis sp. nov. is only known from one cave and occupies the deep subterranean spaces, showing highly troglomorphic features (elongation of appendages, antennomeres and articles, and the strengthening of sensorial equipment of the antennae). 


\section{Plusiocampa (Plusiocampa) corcyraea corcyraea Silvestri, 1912}

Plusiocampa corcyraea Silvestri, 1912: 142, figs xxvii-xxviii.

Diagnosis (Silvestri 1912; Condé 1947a, 1984a)

Non-troglomorphic species. Antennae with 18-21 antennomeres. Pronotum with $1+1 \mathrm{ma}, 3+3 \mathrm{la}, 2+2$ $l p$ macrosetae; mesonotum with $1+1 m a, 3+3 l a, 2+2 l p$ macrosetae; metanotum with $1+1 m a, 1+1 l a$, $2+2$ l $p$ macrosetae; long, barbed notal macrosetae. Two ventral tibial macrosetae; small subequal claws with small lateral crests, posterior claw with no backward overhang. Urotergites I-II with $1+1$ post macrosetae; urotergite III with $2+2$ post macrosetae; urotergite IV with $1+1$ la, $3+3$ post macrosetae; urotergites $\mathrm{V}-\mathrm{VII}$ with $1+1$ la, $4+4$ post macrosetae; urotergite VIII with $6+6$ post macrosetae; abdominal segment IX with $8+8$ post macrosetae; urosternite I with $7+7$, urosternites II-VII with $5+5$, urosternite VIII with 2+2 macrosetae. Male unknown; female with enlarged appendages with glandular $a_{1}$ setae.

\section{Habitat and distribution}

Soil-dwelling species found at two localities on Kerkyra (Corfu), one of the main Ionian islands, and at three localities in continental Greece, in the Epirus region in the east of the Balkan Peninsula.

\section{Plusiocampa (Plusiocampa) corcyraea abdominalis Condé, 1984}

Plusiocampa corcyraea abdominalis Condé, 1984a: 194.

\section{Differential diagnosis against the type form (Condé 1984a)}

Antennae with 22 antennomeres; urotergite III with $1+1$ post macrosetae, instead of $2+2$; urotergite IV with $2+2$ post macrosetae, instead of $3+3$; urotergites V-VII with $3+3$ post macrosetae, instead of $4+4$.

\section{Habitat and distribution}

Soil-dwelling subspecies found only on Ithaca and other large Ionian islands.

Plusiocampa (Plusiocampa) cyrnensis Condé, 1953

Plusiocampa (Plusiocampa) corcyraea cyrnensis Condé, 1953a: 566, figs. 2d-f.

Differential diagnosis against $\boldsymbol{P}$. $(\boldsymbol{P}$.) corcyraea corcyraea (Condé 1953a)

Non-troglomorphic species. Antennae with 20-21 antennomeres. Mesonotum with 2+2 la macrosetae, instead of 3+3; metanotum without la macrosetae, instead of $1+1$ la.

\section{Habitat and distribution}

Soil-dwelling species found at two localities on Corsica.

Plusiocampa (Plusiocampa) dallai Bareth \& Condé, 1984

Plusiocampa dallai Bareth \& Condé, 1984: 138, fig. 3.

Diagnosis (Bareth \& Condé 1984)

Troglomorphic species. Antennae with 32 antennomeres; 8 complex olfactory chemoreceptors with an atypical multi-sheet shape in cupuliform organ; protruding frontal process with tubercular setae. Pronotum with $1+1 m a, 2+2 l a, 2+2 l p$ macrosetae; mesonotum with $1+1 m a, 2+2 l a, 2+2 l p$ macrosetae; metanotum with $1+1 \mathrm{ma}, 1+1 \mathrm{la}, 2+2$ lp macrosetae; long, barbed notal macrosetae; thin, barbed notal 
SENDRA A. et al., Euro-Mediterranean Plusiocampinae and tachycampoid diplurans

clothing setae. Three ventral tibial macrosetae; unequal claws (1.25) with large lateral crests, posterior claw with a backward overhang. Urotergites I-III with $1+1$ post macrosetae; urotergite IV with $1+1$ la, $5+5$ post macrosetae; urotergites $\mathrm{V}-\mathrm{VII}$ with $2+2$ la, $5+5$ post macrosetae; urotergite VIII with $6+6$ post macrosetae; abdominal segment IX with $8+8$ post macrosetae; urosternite I with $7+7$, urosternites II-VII with $5+5$, urosternite VIII with $2+2$ macrosetae. Male unknown, female with subcylindrical appendages with glandular $a_{1}$ setae.

\section{Habitat and distribution}

Subterranean species only known from Grotta di Montenero, in the Gargano Promontory part of the Apulia Carbonate Platform, Italian Peninsula.

Plusiocampa (Plusiocampa) dargilani (Moniez, 1894)

Campodea dargilani Moniez, 1894: 82.

Campodea staphylinus - Viré 1897: 7, figs 1-2 (not Westwood, 1852).

Troglocampa dargilani - Denis 1930 pars: 231, figs 25-28.

Diagnosis (Denis 1923; Condé 1946; Bareth 2006)

Troglomorphic species. Antennae with 40-48 antennomeres; eight to nine complex olfactory chemoreceptors in cupuliform organ; protruding frontal process with tubercular setae. Pronotum with $1+1 \mathrm{ma}, 4+4 \mathrm{la}, 2+2$ lp macrosetae; mesonotum with $1+1 \mathrm{ma}, 2+2 \mathrm{la}, 2+2 \mathrm{lp}$ macrosetae; metanotum with $1+1 m a, 2+2 l a, 2+2-1+1$ lp macrosetae; thin, poorly barbed notal macrosetae; sparse long, thin, barbed notal clothing setae. No ventral tibial macrosetae; unequal claws with large lateral crests, posterior claw with a backward overhang. Urotergite III with $1+1$ la macrosetae; urotergite IV with $1+1 l a, 1+1$ post macrosetae; urotergites V-VII with $1+1$ la, 3+3-4+4 post macrosetae; urotergite VIII with $6+6$ post macrosetae; abdominal segment IX with $8+8$ post macrosetae; urosternite I with $11+11$, urosternites II-VII with 9+9, urosternite VIII with $3+3$ macrosetae. Male with a narrow area of glandular $g_{l}$ setae; subtrapezoidal appendages with an area of glandular $a_{2}$ setae; female with subcylindrical appendages with glandular $a_{1}$ setae. Spermatozoid fascicles 60-65 $\mu \mathrm{m}$ in diameter and 25-30 $\mu \mathrm{m}$ wide, wheels with $2 \frac{1}{2}-3$ turns of $650 \mu \mathrm{m}$ long and $13 \mu \mathrm{m}$ diameter filament.

\section{Remarks}

The study of one female from Puech Cave, Grands Causses, France (see Table S2 in Supplementary Material) has allowed us to supplement the former description, including regarding the presence of only $1+1$ lp metanotal macrosetae.

\section{Habitat and distribution}

Subterranean species, well-spread around the Grands Causses, where it is found in eight caves, living alongside the troglobite $P$. (P.) balsani.

\section{Plusiocampa (Plusiocampa) djurdjurae Condé, 1984}

Plusiocampa djurdjurae Condé, 1984b: 244.

\section{Diagnosis (Condé 1984b)}

Troglomorphic species. Antennae with $34-35$ and 38 antennomeres; 28 simple olfactory chemoreceptors in cupuliform organ; protruding frontal process with tubercular setae. Pronotum with $1+1 \mathrm{ma}, 3+3-2+2$ $l a, 2+2$ lp macrosetae; mesonotum with $1+1 \mathrm{ma}, 2+2 \mathrm{la}, 2+2 \mathrm{lp}$ macrosetae; metanotum with $1+1 \mathrm{ma}$, $1+1$ la, $2+2$ lp macrosetae; long, barbed macrosetae; barbed notal clothing setae. Two or three ventral 
tibial macrosetae; unequal claws (1.4) with large lateral crests, posterior claw with a backward overhang. Urotergites I-III with $1+1$ post macrosetae; urotergite IV with $0+0-1+1$ la, $2+2-3+3$ post macrosetae; urotergites V-VII with $1+1$ la, 5+5 post macrosetae; urotergite VIII with $6+6$ post macrosetae; abdominal segment IX with $8+8$ post macrosetae; urosternite I with $7+7$, urosternites II-VII with $5+5-$ $6+6$, urosternite VIII with $2+2$ macrosetae. Young male with an area of glandular $g_{1}$ setae, enlarged appendages with glandular $a_{1}$ setae; female with subcylindrical appendages with glandular $a_{1}$ setae.

\section{Habitat and distribution}

Subterranean species found in two caves, Ifri Semedane and Ifri Maareb, in the Djurdjura Mountains, Tell Atlas, Algeria, on the former Kabylian microplate.

\section{Plusiocampa (Plusiocampa) dobati Condé, 1975}

Plusiocampa dobati Condé in Dobat, 1975: 321.

Diagnosis (Condé 1993a; Sendra \& Weber 2018)

Troglomorphic species. Antennae with 27-29 antennomeres; 7-9 complex olfactory chemoreceptors on cupuliform organ; protruding frontal process characterized by a frontal and lateral rim with nontubercular setae. Pronotum with $1+1 m a, 3+3 l a, 2+2-3+3 l p$ macrosetae; mesonotum with $1+1 m a$, $2+2-3+3 l a, 2+2$ lp macrosetae; metanotum with $1+1 \mathrm{ma}, 1+1-2+2(2+1) l a, 2+2 l p$ macrosetae; long, barbed notal macrosetae; smooth notal clothing setae. Two ventral tibial macrosetae; unequal claws (1.3) with large lateral crests, posterior claw with a backward overhang; lateral processes smooth and short. Urotergites I-II with $1+1$ post macrosetae; urotergite III with $2+2(2+1)$ post macrosetae; urotergite IV with $0+0-1+1(0+1) l a, 2+2(1+2)$ post macrosetae; urotergite $\mathrm{V}$ with $1+1(1+2) l a, 5+5$ post macrosetae; urotergite VI with $2+2(1+2,2+3)$ la, $5+5$ post macrosetae; urotergite VII with $2+2$ $(1+2)$ la, $5+5$ post macrosetae; urotergite VIII with $6+6$ post macrosetae; abdominal segment IX with $8+8$ post macrosetae; urosternite I with $7+7$, urosternites II-VII with $5+5$, urosternite VIII with $2+2$ macrosetae. Male without glandular $g_{l}$ setae; short enlarged subcylindrical appendages with glandular $a_{1}$ setae; female with subcylindrical appendages, with glandular $a_{1}$ setae.

\section{Habitat and distribution}

Subterranean species found in 13 caves around Swabian Alb, Germany.

Plusiocampa (Plusiocampa) dolichopoda Bareth \& Condé, 1984

Plusiocampa dolichopoda Bareth \& Condé, 1984: 141, fig. 4.

Diagnosis (Bareth \& Condé 1984)

Troglomorphic species. Frontal process with non-tubercular setae. Pronotum with $1+1 \mathrm{ma}, 2+2 \mathrm{la}, 2+2$ $l p$ macrosetae; mesonotum with $1+1 m a, 1+1 l a, 2+2 l p$ macrosetae; metanotum with $1+1 m a, 2+2 l p$ macrosetae; long, barbed notal macrosetae. One ventral tibial macroseta; subequal claws with small lateral crests, posterior claw with no backward overhang. Urotergites I-IV with 1+1 post macrosetae; urotergites V-VII with $4+4$ post macrosetae; urotergite VIII with $6+6$ post macrosetae; abdominal segment IX with $8+8$ post macrosetae; urosternite I with $7+7$, urosternites II-VII with $5+5$, urosternite VIII with $2+2$ macrosetae. Adults unknown.

\section{Habitat and distribution}

Description based on a single juvenile from only one cave, Grotta Trojano, Jacotenente, the Gargano Promontory part of the Apulia Carbonate Platform, Italian Peninsula. 
SENDRA A. et al., Euro-Mediterranean Plusiocampinae and tachycampoid diplurans

Plusiocampa (Plusiocampa) dolichopoda inguscioni Bareth, 2002

Plusiocampa dolichopoda inguscioni Bareth, 2002: 122, figs 1-2.

Differential diagnosis against the type form (Bareth 2002)

Pronotum with $3+3$ lateral posterior macrosetae, instead of $2+2$ in the type form.

\section{Habitat and distribution}

Subterranean subspecies inhabiting one cave, Grotte Scaloria, Manfredonia, Gargano, Italian Peninsula, near the type locality.

Plusiocampa (Plusiocampa) dublanskii Sendra \& Turbanov sp. nov. urn:lsid:zoobank.org:act:66D5D570-F8DC-43CF-936B-DE8512631B55

Figs $47-48$

\section{Etymology}

This species is named in honour of Professor V.N. Dublyansky (1930-2012), who was the instigator of complex karstological and speleological studies of the Kizil-Koba (= Krasnaya) Cave.

\section{Material examined}

\section{Holotype}

CRIMEA -1 ố; Simferopol District, Dolgorukovsky karst massif, Kizil-Koba (= Krasnaya) Cave; 5 Nov. 2014; I.S. Turbanov leg.; ZMMU Dip0006.

\section{Description}

Body. Body length $2.7 \mathrm{~mm}$. Epicuticle smooth under optical microscope but with a reticulate surface under SEM (Fig. 47); body with sparse thin and middle-sized clothing setae with 1-3 thin distal barbs.

HEAD. Two intact antennae with 35 antennomeres, longer than body length $(3.2 \mathrm{~mm})$; thin subcylindrical sensillum on third antennomere in ventral position between macrosetae $d$ and $e$; central antennomeres $2.1 \times$ as long as wide, apical antennomere $3.0 \times$ as long as wide; cupuliform organ occupying $1 / 7$ of its length, with nine complex olfactory chemoreceptors; gouge sensilla $40-50 \mu \mathrm{m}$ long in a single whorl of 10-12 sensilla on each medial and distal antennomere; a small, thin subcylindrical sensillum on third antennomere. Non-protruding frontal process with very slightly tubercular frontal macrosetae. Frontal process plain, with very slight tubercular frontal macrosetae; macrosetae along line of insertion of antennomere and $x$ setae similar in length and with a few distal barbs $(a / i / p / x$ with relative lengths of 29/19/24/25). Small suboval labial palps with a large subcylindrical sensillum, two guard setae, five normal setae and up to 20 neuroglandular setae.

THORAX. Thoracic macrosetal distribution: pronotum with $1+1 m a, 2+2 l a_{2}, 2+2 l p_{2,3}$; mesonotum with $1+1 \mathrm{ma}, 2+2 l a_{2,3}, 2+2 l p_{2,3}, 1+1 \mathrm{mp}$; metanotum with $1+1 \mathrm{ma}, 2+2 l p_{2,3}, 1+1 \mathrm{mp}$. All notal macrosetae long and barbed along distal two-thirds; marginal setae similar to clothing setae, but a bit longer. Legs elongated (1.53 mm long), overpassing end of abdomen. Femur I without dorsal macrosetae; femora II-III with one dorsal macroseta inserted on distal third. No ventral tibial macrosetae. Calcars with 2-3 rows of long barbs, from base with a smooth and narrow lateral side along each calcar. Dorsal and lateral subapical tarsal macrosetae smooth. Very unequal claws, posterior claw $1.80-2.05 \times$ as long as anterior one, including a large backward overhang in posterior claw; ventral surface of claws with grooves, dorsal surface including large lateral crests with thin stripes. Posterior claw with a long, setiform pretarsal process reaching claw; anterior claw with short pretarsal processes without reaching extremity of this short claw (Figs 48-49). 
ABDomen. Distribution of abdominal macrosetae on tergites: $1+1$ post $_{1}$ on I-III; $1+1$ la $1+1$ post $t_{1}$ on IV; $1+1$ la, 2+2 post ${ }_{l, 2}$ on V; $1+1$ la, $3+3$ post $_{l, 2,3}$ on VI; $1+1$ la, 4+4 post $t_{l, 2,3,4}$ on VII; $5+5$ post on VIII; $8+8$ post on abdominal segment IX. All post urotergal macrosetae long, robust, barbed; la urotergal
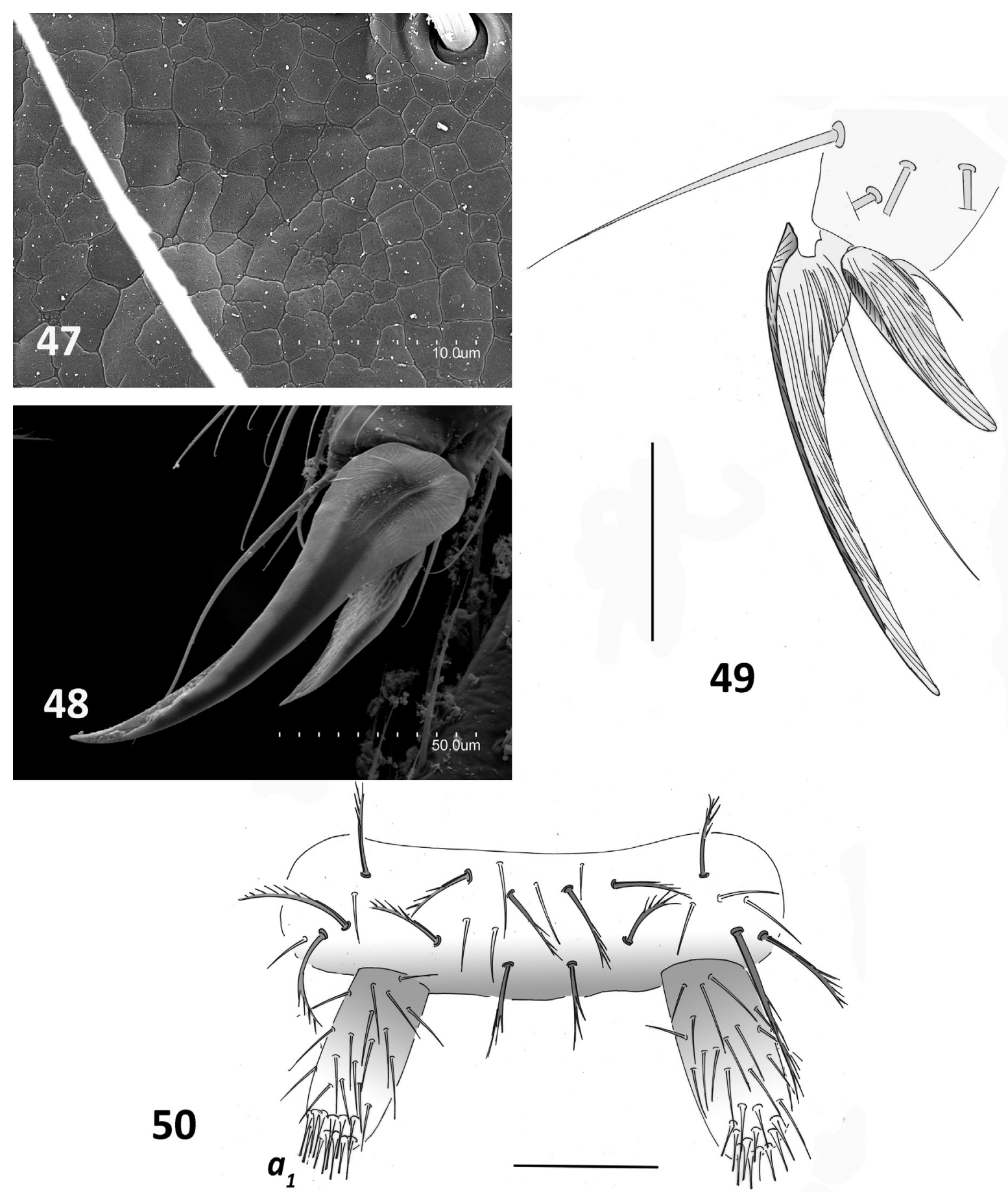

Figs 47-50. - 47-48. Plusiocampa (Plusiocampa) dublanskii Sendra \& Turbanov sp. nov. 47. Specimen from Kizil-Koba (= Krasnaya) Cave, Dolgorukovsky karst massif, Crimean Peninsula (Coll. AS); surface of metanotum, detail. 48. Holotype, $\widehat{\jmath}, 2.7 \mathrm{~mm}$ long, from same locality (ZMMU Dip0006); pretarsus, dorsal view. - 49-50. P. (P.) aff. dublanskii Sendra \& Turbanov sp. nov., Õ, $2.8 \mathrm{~mm}$ long, from Abrskila Cave, Abkhazia, Western Caucasus (ZMMU). 49. Metathoracic pretarsus. 50. Urosternite I. Scale bars: $49=50 \mu \mathrm{m} ; 50=0.1 \mathrm{~mm}$. 
macrosetae much shorter, with thin distal barbs. Urosternite I with $7+7$, urosternites II-VII with $5+5$, urosternite VIII with $2+2$ macrosetae; all urosternal macrosetae robust, large, covered by long barbs along distal half to three-fourths. Thick stylus with almost smooth stylar setae.

SECONDARY SEX Characters. Male urosternite I without glandular $g_{l}$ setae, with subcylindrical, short and enlarged appendages with up to 15 large glandular $a_{1}$ setae, with spermatozoid fascicles. Female unknown.

Plusiocampa (Plusiocampa) aff. dublanskii sp. nov.

Fig. 49-50

\section{Material examined}

WESTERN CAUCASUS • 1 §; Abkhazia, Ochamchira District, near Otap Village, Abrskila Cave; 9 Sep. 2014; I.S. Turbanov leg.; ZMMU.

\section{Remarks}

Body length $2.8 \mathrm{~mm}$. It shows some differences from the type form in the number of macrosetae on the pronotum $\left(1+2 l a_{2,3}\right)$, metanotum $(1+1 l a)$, urotergite IV (without $l a$ macrosetae), urotergite $\mathrm{V}$ (without la and $1+1$ post $\left._{1}\right)$, urotergite VI $\left(1+1\right.$ la, $2+2$ post $\left._{l, 2}\right)$, urotergite VII $\left(2+2 l_{2,3}, 2+2\right.$ post $\left._{l, 2}\right)$, urotergite VIII $(4+4$ post $)$ and abdominal segment IX $(7+7$ post $)$.

\section{Phyletic affinities, habitat and distribution}

Among the described species of Plusiocampa s. str., P. (P.) bulgarica, $P(P$.) elongata, $P$. (P.) vodniensis and $P$. (P.) beroni from the Balkan karst region (Condé 1954a; Bareth \& Condé 2001; Sendra et al. 2012b), P. (P.) strouhali, P. (P.) caprai, P. (P.) grandii and P. (P.) hoelzeli from the Alps (Condé 1954a; Neuherz 1984) and $P$. (P.) fagei from caves on Mallorca (Condé 1955b) share two important taxonomic characters with $P$. (P.) dublanskii sp. nov.: the distinctly unequal claws with large lateral crests and an evident backward overhang on the posterior claw, and the presence of medial posterior macrosetae on the mesonotum and metanotum. Nonetheless, the absence of ventral tibial macrosetae or the extremely unequal claws with unequal lateral pretarsal processes suggest a completely different relationship with the unclear subgenus Venetocampa from the Veneto region, northern Italian Peninsula. These new troglomorphic taxa live in two separated karst regions in the north (Crimea) and the east (Western Caucasus) of the Black Sea. The important differences between the two studied specimens are remarkable, in particular the number and distribution of the macrosetae on the urotergites and abdominal segment, something that should be reviewed in the future with further samples.

Plusiocampa (Plusiocampa) elongata Ionescu, 1955

Plusiocampa elongata Ionescu, 1955: 43, figs 18-19.

Diagnosis (Ionescu 1955, Sendra et al. 2012b)

Troglomorphic species. Antennae with 30-35 antennomeres; cupuliform organ with four complex olfactory chemoreceptors; protuding frontal process with very slightly tubercular setae. Pronotum with $1+1 \mathrm{ma}, 4+4 \mathrm{la}, 2+2 \mathrm{lp}$ macrosetae; mesonotum with $1+1 \mathrm{ma}, 3+3 \mathrm{la}, 2+2 \mathrm{lp}, 1+1 \mathrm{mp}$ macrosetae; metanotum with $1+1 \mathrm{ma}, 2+2 \mathrm{la}, 2+2 \mathrm{lp}, 1+1 \mathrm{mp}$ macrosetae; long, barbed notal macrosetae; abundant notal clothing setae. Two or three ventral tibial macrosetae; unequal claws (1.15-1.30) with large lateral crests, posterior claw with a backward overhang. Urotergites I-II with $1+1$ post macrosetae; utrotergite III with $0+0-1+1$ la, $3+3-4+4$ post macrosetae; urotergite IV with $1+1-2+2-3+3$ la, 4+4 post macrosetae; urotergite $\mathrm{V}$ with $2+2-3+3$ la, $5+5$ post macrosetae; urotergites VI-VII with $3+3$ la, $5+5$ post macrosetae; urotergite VIII with $6+6$ post macrosetae; abdominal segment IX with $8+8$ post macrosetae; urosternite I with $8+8$, urosternites II-VII with $5+5$, urosternite VIII with $2+2$ macrosetae. Male without glandular $g_{1}$ setae, with enlarged, thick subtrapezoidal appendages with a large area of 
glandular $a_{1}$ setae; female with enlarged, thick subcylindrical appendages with a few glandular $a_{1}$ setae. Spermatozoid fascicles $70 \mu \mathrm{m}$ in diameter, wheels with $2 \frac{1}{2}$ turns of $400 \mu \mathrm{m}$ long and $7 \mu \mathrm{m}$ wide filament.

\section{Plusiocampa (Plusiocampa) aff. elongata Ionescu, 1955}

\section{Differential diagnosis against the type form (Sendra et al. 2012b)}

Urotergite I with $0+0-0+1-1+1$ post macrosetae; urotergites II-III with $1+1$ post macrosetae; urotergite IV with $2+2$ post macrosetae; urotergites V-VII with $1+1$ la, $4+4$ post macrosetae.

\section{Habitat and distribution}

Subterranean species found in nine caves around the Carpathian Mountains in Romania; $P$. (P.) aff. elongata has only been found in one cave, the Peştera Cloşani cave.

\section{Plusiocampa (Plusiocampa) exsulans Condé, 1947}

Plusiocampa exsulans Condé, 1947a: 27, fig. 5.

Diagnosis (Condé 1947a, 1955a, 1966; Bareth 1988)

Non-troglomorphic species. Antennae with 21-25 antennomeres; four simple olfactory chemoreceptors in cupuliform organ; non-protruding frontal process with non-tubercular setae. Pronotum with $1+1 \mathrm{ma}$, $3+3 l a, 2+2 l p$ macrosetae; mesonotum with $1+1 m a, 3+3 l a, 2+2 l p$ macrosetae; metanotum with $1+1$ $m a, 1+1$ la, $2+2$ lp macrosetae; long, barbed notal macrosetae; smooth notal clothing setae. Two ventral tibial macrosetae. Small subequal claws (1.05) with middle-sized lateral crests, posterior claw with no backward overhang. Urotergites I-II with $1+1$ post macrosetae; urotergite III with $2+2$ post macrosetae; urotergites IV-V with $1+1$ la, $5+5$ post macrosetae; urotergites VI-VII with $2+2(2+1)$ la, $5+5$ post macrosetae; urotergite VIII with $6+6$ post macrosetae; abdominal segment IX with $8+8$ post macrosetae; urosternite I with $7+7$, urosternites II-VII with $5+5$, urosternite VIII with $2+2$ macrosetae. Male with an area of glandular $g_{1}$ setae, subcylindrical enlarged appendages with glandular $a_{1}$ setae; female with slender subcylindrical appendages with glandular $a_{1}$, setae. Spermatozoid fascicle wheels with $1 \frac{1}{2}$ turns of $150 \mu \mathrm{m}$ long and $10 \mu \mathrm{m}$ diameter filament.

\section{Remarks}

The study of five specimens from two caves in Slovenia and Trieste, Italy, and one from Faedo San Michele, Trento, Italy (see Table S2 in Supplementary Material) allowed the addition of information to the diagnosis.

\section{Habitat and distribution}

Hypogean species found in caves and frequently in soil. A total of 20 localities are reported from around Central Europe, from the Czech Republic and Slovakia to the Italian and Dinaric Mountains, reaching Croatia and Bosnia and Herzegovina towards the east and France towards the west, where it has been found in garden soils. This species is often found in urban soils, e.g., at ca 20 sites in Vienna (Christian 1992). The presence of $P$. (P.) cf. exsulans on the Anatolian Peninsula (Sendra et al. 2006) must be confirmed.

\section{Plusiocampa (Plusiocampa) fagei Condé, 1955}

Figs 51-52

Plusiocampa fagei Condé, 1955b: 129, figs 3d, 4.

Diagnosis (Condé 1955b)

Troglomorphic species. Antennae with 39-48 antennomeres; 21 complex olfactory chemoreceptors in cupulifrom organ; protruding frontal process with non-tubercular setae. Pronotum with $1+1 \mathrm{ma}, 2+2$ 

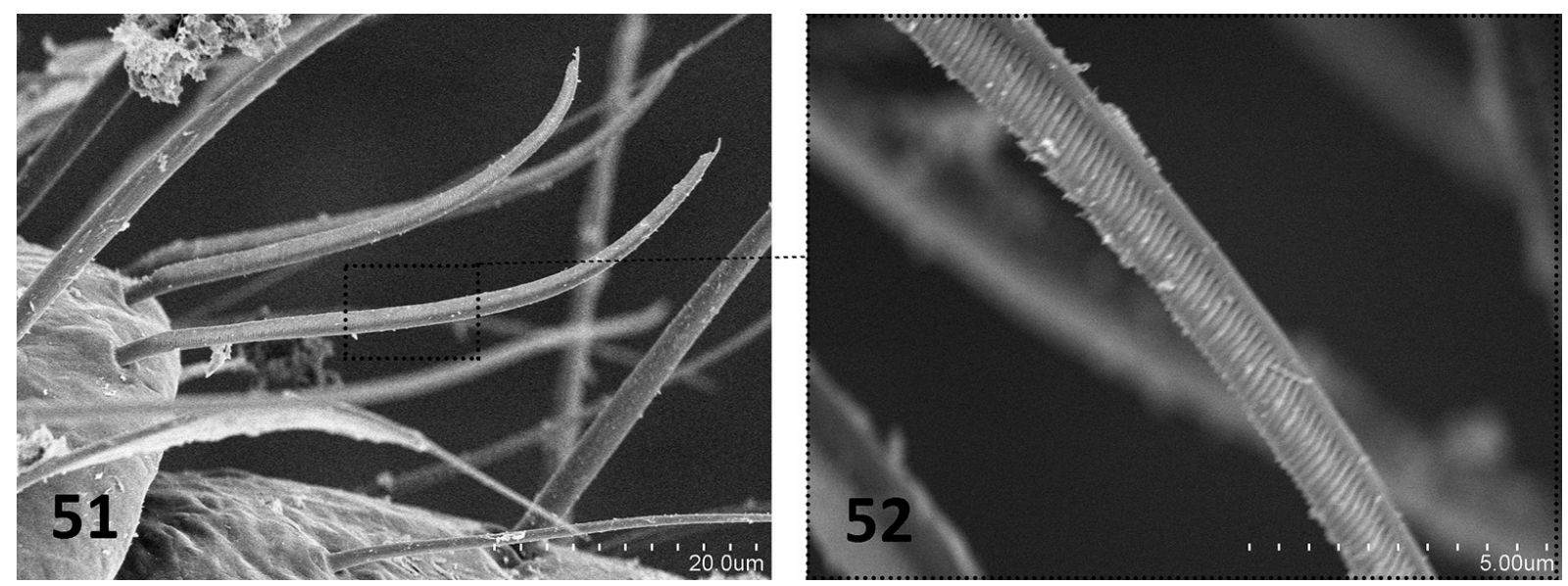

Figs 51-52. Plusiocampa (Plusiocampa) fagei Condé, 1955, from Cova Sa Gleda, Manacor, Mallorca Island (Coll. AS). 51. Lateral distal side of a medial antennomere. 52. Detail of a gouge sensillum.

$l a, 2+2$ lp macrosetae; mesonotum with $1+1 \mathrm{ma}, 2+2 \mathrm{la}, 2+2 \mathrm{lp}, 1+1 \mathrm{mp}$ macrosetae; metanotum with $1+1 m a, 1+1 l a, 2+2 l p, 1+1 m p$ macrosetae; long, barbed notal macrosetae; sparse notal clothing setae. Two or three ventral tibial macrosetae; unequal claws (1.25) with large lateral crests, posterior claw with a backward overhang. Urotergites I-II with $1+1$ post macrosetae; urotergite III with $0+0-1+1$ la, $2+2$ post macrosetae; urotergite IV with $1+1$ la, $2+2-4+4$ post macrosetae; urotergites V-VII with $1+1$ la, $5+5$ post macrosetae; urotergite VIII with $6+6$ post macrosetae; abdominal segment IX with $8+8$ post macrosetae; urosternite I with $6+6-8+8$, urosternites II-VII with $5+5$, urosternite VIII with $2+2$ macrosetae. Male with a narrow area of glandular $g_{1}$ setae and very long cylindrical appendages with glandular $a_{l}$ setae; female with thin subcylindrical appendages with glandular $a_{l}$ setae.

\section{Remarks}

Two specimens from Cova Sa Gleda, Manacor, Mallorca (see Table S2 in Supplementary Material) were used for SEM to look at some features that are difficult to observe under an optical microscope, such as their thin gouge sensilla, $48-50 \mu \mathrm{m}$ long with an external transversal striped surface (Figs 51-52).

\section{Habitat and distribution}

Subterranean species inhabiting 19 caves in Mallorca, Balearic Islands, mainly in the Tramuntana mountain chain on the north of the island.

\section{Plusiocampa (Plusiocampa) festae Silvestri, 1932}

Plusiocampa festae Silvestri, 1932: 75, figs x-xi.

Plusiocampa festae coi Silvestri, 1932: 78.

\section{Diagnosis (Silvestri 1933a; Condé 1984a)}

Slightly troglomorphic species. Antennae with 25 and 35 antennomeres. Non-protruding frontal process with non-tubercular setae. Pronotum with $1+1 m a, 3+3 l a, 2+2 l p$ macrosetae; mesonotum with $1+1 m a$, $3+3 l a, 2+2 l p, 1+1 \mathrm{mp}$ macrosetae; metanotum with 1+1 ma, 2+2 lp, 1+1 mp macrosetae; long, barbed notal macrosetae; abundant notal clothing setae. Two (rarely three) ventral tibial macrosetae; subequal claws (1.1) with large lateral crests; posterior claw with no backward overhang. Urotergites I-II with $1+1$ post macrosetae; urotergite III with $1+0$ la, $1+1$ post macrosetae; urotergite IV with $1+1$ la, $2+2-$ $3+3$ post macrosetae; urotergites V-VII with $1+1$ la, $5+5$ post macrosetae; urotergite VIII with $7+7$ post macrosetae; abdominal segment IX with $9+9$ post macrosetae; urosternite I with $7+7$, urosternites II-VII 
with $5+5$, urosternite VIII with $2+2$ macrosetae. Male with an area of glandular $g_{1}$ setae and enlarged appendages with glandular $a_{1}$ setae.

\section{Remarks}

The studied material (see Table S2 in Supplementary Material) from MSS habitats was collected from inland Greece. Three specimens from Évia show variability in the number of post macrosetae on the third urotergite; they have $2+1,2+2$ and $3+3$ post macrosetae, showing the dubious value of the subspecies $P$. (P.) festae coi. In addition, a juvenile from Montes Orno, Crete, has also been studied and it matches in all chaetotaxic characters with $P$. (P.) festae festae. In conclusion, we suggest that $P$. (P.) festae coi should be synonymized with the nominate subspecies.

\section{Habitat and distribution}

Soil-dwelling species previously found on Karpathos and Leros, islands of the Dodecanese Archipelago; also collected in endogean environments at two sites on Crete and at a locality near Izmir, Anatolia, Turkey. It seems to inhabit MSS, where it has also been found at 14 localities in continental Greece.

Plusiocampa (Plusiocampa) friulensis Bareth \& Condé, 1984

Plusiocampa friulensis Bareth \& Condé, 1984: 136, fig. 2.

Diagnosis (Bareth \& Condé 1984)

Slightly troglomorphic species. Antennae with 27 antennomeres; seven simple olfactory chemoreceptors in cupuliform organ; frontal process with non-tubercular setae. Pronotum with $1+1 \mathrm{ma}, 3+3 \mathrm{la}, 2+2 \mathrm{lp}$ macrosetae; mesonotum with $1+1 \mathrm{ma}, 3+3 \mathrm{la}, 2+2 \mathrm{lp}, 1+1 \mathrm{mp}$ macrosetae; metanotum with $1+1 \mathrm{ma}, 1+1$ $l a, 2+2 l p, 1+1 \mathrm{mp}$ macrosetae; long, barbed notal macrosetae. Two ventral tibial macrosetae. Unequal claws (more than 1.2) with large lateral crests, posterior claw with a backward overhang. Urotergites III with $1+1$ post macrosetae; urotergite III with $2+2$ post macrosetae; urotergite IV with $1+1$ la, $4+4$ post macrosetae; urotergite $\mathrm{V}$ with $1+1$ la, $5+5$ post macrosetae; urotergites VI-VII with $2+2$ la, $5+5$ post macrosetae; urotergite VIII with $6+6$ post macrosetae; abdominal segment IX with $8+8$ post macrosetae; urosternite I with $7+7$, urosternites II-VII with $5+5$, urosternite VIII with $2+2$ macrosetae. Male with a large area of glandular $g_{l}$ setae and enlarged appendages with a large area of glandular $a_{1}$ setae; female appendages thinner than those of male, with glandular $a_{1}$ setae.

\section{Habitat and distribution}

Subterranean species found at Inghiottitoio di Val dei Pai, Montereale Valcellina, Pordenone, Carnic Pre-Alps, Italy.

Plusiocampa (Plusiocampa) gadorensis Sendra, 2001

Plusiocampa gadorensis Sendra, 2001: 73, figs 1-4, tables i-ii.

Diagnosis (Sendra 2001)

Troglomorphic species. Antennae with 46-52 antennomeres; 15-18 complex olfactory chemoreceptors in cupuliform organ; small protruding frontal process with a few slightly tubercular setae. Pronotum with $1+1 \mathrm{ma}, 2+2-3+3 \mathrm{la}, 2+2$ lp macrosetae; mesonotum with $1+1 \mathrm{ma}, 2+2 \mathrm{la}, 2+2(2+3) l p$ macrosetae; metanotum with $1+1 \mathrm{ma}, 2+2 \mathrm{la}, 2+2(2+3) l p$ macrosetae; long, barbed notal macrosetae; short notal clothing setae. Two or three ventral tibial macrosetae; slightly unequal claws (1.15) with large lateral 
crests, posterior claw with no backward overhang. Urotergite II with $0+0-1+1(0+1)$ post macrosetae; urotergite III with $0+0-1+1 l a, 1+1-2+2(0+1)$ post macrosetae; urotergite IV with $1+1(1+2) l a, 3+3-$ $4+4(4+5)$ post macrosetae; urotergite $\mathrm{V}$ with $1+1(1+2)$ la, $4+4-5+5(4+5)$ post macrosetae; urotergite VI with $1+1(1+2)$ la, $5+5(4+5)$ post macrosetae; urotergite VII with $1+1$ la, 5+5 (4+5) post macrosetae; urotergite VIII with $6+6(6+5)$ post macrosetae; abdominal segment IX with $8+8$ post macrosetae; urosternite I with $7+7-8+8(8+9)$, urosternites II-VII with $5+5$, urosternite VIII with $2+2$ macrosetae. Male with an area of glandular $g_{1}$ setae, subcylindrical appendages with glandular $a_{1}$ setae; female and male appendages identical.

\section{Habitat and distribution}

Subterranean species endemic to the isolated karst of Sierra de Gádor, in the Peni-Baetic System, southeastern Iberian Peninsula. It is known from seven natural caves and one mine.

Plusiocampa (Plusiocampa) glabra Condé, 1984

Plusiocampa glabra Condé, 1984a: 195, figs 7-9.

Diagnosis (Condé 1984a)

Troglomorphic species. Antennae with 43 antennomeres; 14 olfactory chemoreceptors within cupuliform organ; non-protruding frontal process with non-tubercular setae. Pronotum with $1+1 m a, 3+3 l a, 2+2 l p$ macrosetae; mesonotum with $1+1 \mathrm{ma}, 2+2 \mathrm{lp}, 1+1 \mathrm{mp}$ macrosetae; metanotum with $1+1 \mathrm{ma}, 1+1 \mathrm{lp}, 1+1$ $m p$ or smp macrosetae; thin, poorly barbed notal macrosetae; very sparse notal and urotergal clothing setae. Two ventral tibial macrosetae; subequal claws (1.0-1.1) with large lateral crests, posterior claw with a small backward overhang. Urotergites I-IV without macrosetae; urotergite V with $2+2(1+2$, $2+3)$ post macrosetae; urotergite VI with $1+1$ la, $2+2$ to $4+4$ post macrosetae; urotergite VII with $1+1$ la, 3+3-4+4 post macrosetae; urotergite VIII with $7+7$ post macrosetae; abdominal segment IX with $9+9$ post macrosetae; urosternite I with $7+7$, urosternites II-VII with $5+5$, urosternite VIII with $2+2$ macrosetae. Male with a row of glandular $g_{1}$ setae and thin subcylindrical appendages with glandular $a_{1}$ setae; female and male appendages identical.

\section{Habitat and distribution}

Subterranean species found in Greece, namely at Spilaio Tripa tou Kalivaki, Klenia, Corinthos, southern Balkan Peninsula.

Plusiocampa (Plusiocampa) grandii Silvestri, 1933

Plusiocampa grandii Silvestri, 1933b: 1, figs i-ii.

Diagnosis (Silvestri 1933b; Condé 1954a)

Troglomorphic species. Antennae with 33-38 antennomeres. Pronotum with 1+1 ma, 2+2 la, 2+2 lp macrosetae; mesonotum with $1+1 \mathrm{ma}, 2+2 \mathrm{la}, 2+2 \mathrm{lp}, 1+1 \mathrm{mp}$ macrosetae; metanotum with $1+1 \mathrm{ma}$, $1+1$ la, $2+2$ lp, $1+1 \mathrm{mp}$ macrosetae; long, barbed notal macrosetae; abundant clothing setae. Three ventral tibial macrosetae; unequal claws (1.25) with large lateral crests, posterior claw with a backward overhang. Urotergites I-II with $1+1$ post macrosetae; urotergite III with $1+1$ la, $1+1$ post macrosetae; urotergite IV with $1+1$ la, $5+5$ post macrosetae; urotergites $\mathrm{V}-\mathrm{VII}$ with $2+2$ la, $5+5$ post macrosetae; urotergite VIII with $6+6$ post macrosetae; urosternite I with $7+7$, urosternites II-VII with $6+6$, urosternite VIII with $2+2$ macrosetae. Male unknown; female with subcylindrical appendages bearing glandular $a_{1}$ setae. 
Plusiocampa (Plusiocampa) aff. grandii Silvestri, 1933

\section{Differential diagnosis against the type form}

Observation of a single female from Inamila Cave in Evia, Greece (Coll. AS). It shows remarkable differences from the type form, such as the more anterior insertion position of $m p$ mesonotal and metanotal macrasetae and post macrosetae on urotergites I-III. In addition, this Greek form shows important differences in the number and distribution of urotergal macrosetae: urotergite III with $1+0$ la, $1+1$ post; urotergite IV with $1+1$ la, $4+5$ post; urotegites VI-VII with $3+3$ la, $5+5$ post. Others features are: protruding frontal process with abundant tubercular setae; subequal claws with large lateral crests, posterior claw with a backward overhang; smooth subapical tarsal setae; stylus setae with abundant but separated barbs.

\section{Habitat and distribution}

Subterranean species only found in Bus del Globo Cave, in Trentino, Italian Alps. The aff. form from a cave in Greece should be accepted with caution, as it could be a new taxon.

Plusiocampa (Plusiocampa) gueorguievi Bareth \& Condé, 2001

Plusiocampa gueorguievi Bareth \& Condé, 2001: 24, fig. 9.

Diagnosis (Bareth \& Condé 2001)

Troglomorphic species. Antennae with 29-31 antennomeres; six simple olfactory chemoreceptors in cupuliform organ on probably regenerated antenna; protruding frontal process with tubercular setae. Pronotum with $1+1 m a, 3+3 l a, 2+2 l p$ macrosetae; mesonotum with $1+1 m a, 1+1 l a, 2+2 l p$ macrosetae; metanotum with $1+1 \mathrm{ma}, 0+1 \mathrm{la}, 2+2 \mathrm{lp}$ macrosetae; long, barbed notal macrosetae; barbed notal clothing setae. Two ventral tibial macrosetae; unequal claws (1.5) with large lateral crests, posterior claw with a backward overhang. Urotergite IV with $1+1$ la, $2+2$ post macrosetae; urotergites V-VII with $1+1$ la, $4+4$ post macrosetae; urotergite VIII with $6+6$ post macrosetae; abdominal segment IX with $8+8$ post macrosetae; urosternite I with $7+7$, urosternites II-VII with $5+5$, urosternite VIII with $2+2$ macrosetae. Male with an area of glandular $g_{1}$ setae, enlarged appendages with glandular $a_{1}$ setae.

\section{Habitat and distribution}

Subterranean species found in Toplya Cave, Stara Planina Mountains (= Balkan Mts), Bulgaria.

Plusiocampa (Plusiocampa) hoelzeli (Neuherz, 1984)

Figs 53-58; Table 5

Torocampa hölzeli Neuherz, 1984: 416, figs 1-23, tables i-ii.

\section{Diagnosis (Neuherz 1984)}

Troglomorphic species. Antennae with 34-35 antennomeres; 10-12 complex olfactory chemoreceptors in cupuliform organ; protruding frontal process with non-tubercular setae. Pronotum with $1+1 m a$, $2+2-3+3 l a, 2+2$ lp macrosetae; mesonotum with $1+1 s m a, 1+1 l a, 2+2 l p, 1+1(0+1) s m p$ macrosetae; metanotum with $1+1$ lp macrosetae; long, barbed notal macrosetae; long, abundant notal clothing setae. One ventral tibial macroseta (two and three in Renejevo brezno); unequal claws (1.5) with large lateral crests, posterior claw with a backward overhang. Urotergite IV with $0+0-1+1$ la, $1+1$ post macrosetae; urotergite $\mathrm{V}$ with $1+1$ la, $2+2-3+3$ post macrosetae; urotergites VI-VII with $1+1$ la, $4+4$ 
post macrosetae; urotergite VIII with $5+5$ post macrosetae; abdominal segment IX with $7+7-8+8$ post macrosetae; urosternite I with $7+7$, urosternites II-VII with $5+5$, urosternite VIII with $2+2$ macrosetae. Male with glandular $g_{1}$ setae, slightly enlarged subcylindrical appendages with abundant glandular $a_{1}$ setae; female with subcylindrical appendages with glandular $a_{1}$ setae.
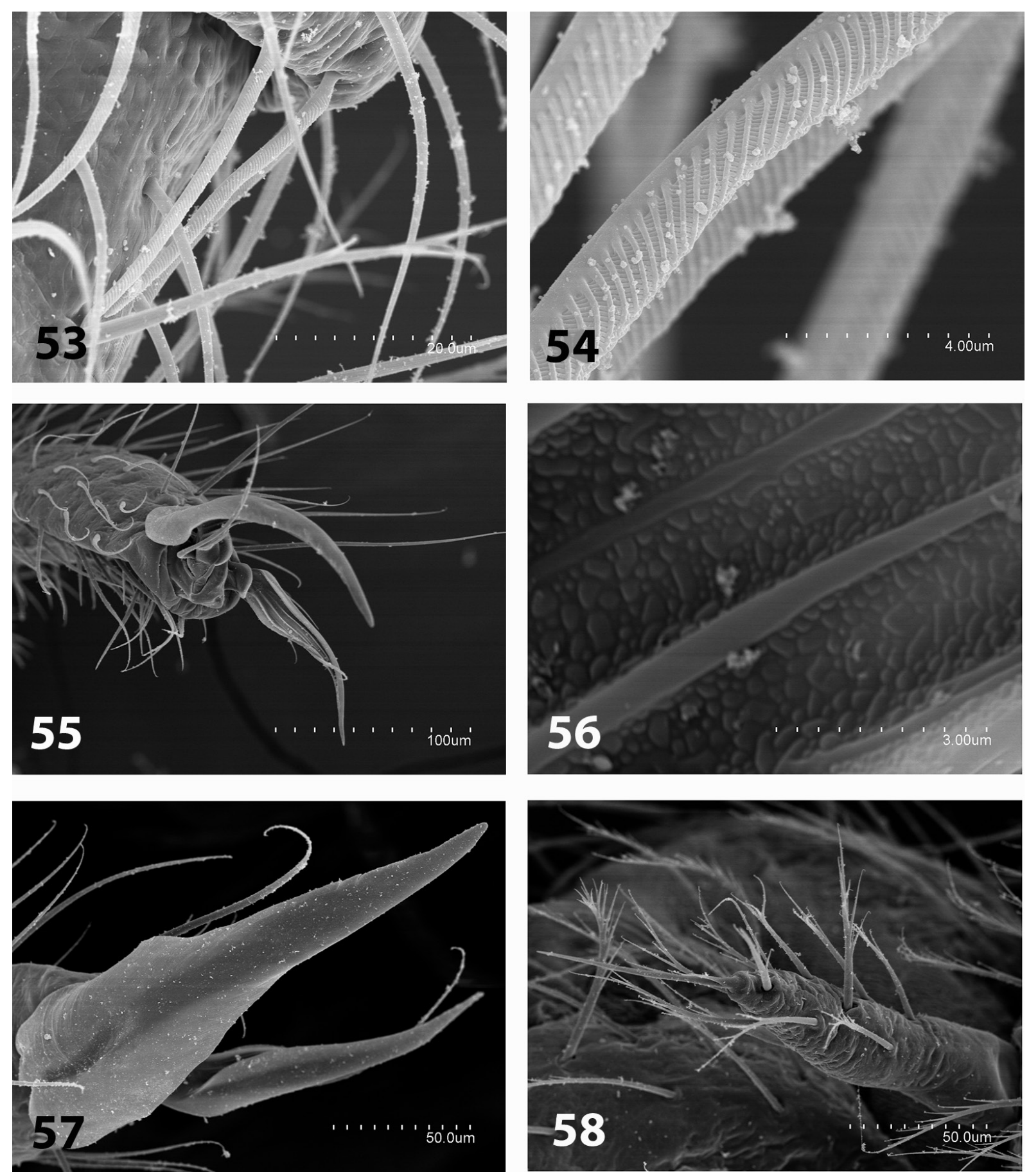

Figs 53-58. Plusiocampa (Plusiocampa) hoelzeli (Neuherz, 1984), from Renejevo brezno Cave, collected at a depth of 1180 meters, Kanin Mountains, Slovenia (Coll. AS). 53. Lateral side of a middle antennomere with several gouge sensilla. 54. Medial portion of several gouge sensilla, detail. 55. Pretarsus, lateral posterior view. 56. Ventral surface of anterior claw, detail. 57. Pretarsus, with posterior claw in the foreground, dorsal view. 58. Abdominal stylus. 
Table 5. Plusiocampa (Plusiocampa) hoelzeli (Neuherz, 1984) from Renejevo brezno. Length of the body, antennae, cerci, metathoracic legs and their segments: trochanter, femur, tibia and tarsus (measurements in $\mathrm{mm}$ ), in addition to the number of antennomeres and cercal articles

\begin{tabular}{|c|c|c|c|c|c|c|c|c|c|c|c|}
\hline \multirow{2}{*}{$\begin{array}{l}\text { Specimen } \\
\text { (Coll. AS) }\end{array}$} & \multirow{2}{*}{$\begin{array}{l}\text { Body } \\
\text { length }\end{array}$} & \multicolumn{2}{|c|}{ Antennae } & \multicolumn{6}{|c|}{ Metathoracic legs } & \multicolumn{2}{|c|}{ Cerci } \\
\hline & & Length & $\begin{array}{c}\text { No. of } \\
\text { antennomeres }\end{array}$ & Coxa & Trochanter & Femur & Tibia & Tarsus & Total & Length & $\begin{array}{l}\text { No. of } \\
\text { articles }\end{array}$ \\
\hline juv. & 3.4 & 2.80 & 35 & 0.10 & 0.10 & 0.55 & 0.45 & 0.50 & 1.70 & 1.95 & base +3 \\
\hline 01 & 4.7 & - & - & 0.20 & 0.20 & 0.80 & 0.85 & 0.70 & 2.75 & 4.60 & base +7 \\
\hline+02 & 4.8 & 3.95 & 34 & 0.20 & 0.20 & 0.85 & 0.90 & 0.80 & 2.95 & - & - \\
\hline$q_{01}$ & 5.1 & 4.80 & 34 & 0.25 & 0.25 & 1.00 & 1.15 & 0.80 & 3.45 & 5.60 & base +9 \\
\hline
\end{tabular}

\section{Remarks}

Five specimens (three females, one male and one juvenile) of Plusiocampa were collected at a very deep location, $>1180$ m deep in Renejevo brezno, Kanin Mountain, Slovenia (see Table S2 in Supplementary Material). No other dipluran has yet been found at such a depth, with the exception of specimens of Plusiocampa (Stygiocampa) sp. presently under study from the Lukina jama-Trojama cave system in Croatia, collected by Branko Jalžić (Kazimir Micilinić, pers. obs.). These specimens match the thoroughly described population of $P$. (P.) hoelzeli found only in Hafnerhöhle, Karawanken Mountains in Carinthia. Nevertheless, there is some variability in important taxonomic features. First, the number of ventral tibial macrosetae on the metathoracic leg, with two (three in one leg) rather than only one; presumably, only the prothoracic legs were observed in the original description. In addition, there is variability in the antennomeres and cercal articles; their mesurements are recorded (Table 5). Body length from 3.4 to $5.1 \mathrm{~mm}$; antennae shorter than body length, with 10-12 complex olfactory chemoreceptors in cupuliform organ; a whorl of gouge sensilla, 34-38 $\mu \mathrm{m}$ long, on each medial and distal antennomere, with an oblique striation (Figs 53-54); small protruding frontal process with slightly tuberculate anterior macrosetae; pronotum with $1+1 m a, 1+1-2+2$ la, $2+2$ lp macrosetae; mesonotum with $1+1$ la, $2+2$ lp macrosetae; metanotum with $1+1-0+0$ lp $(0+1-1+1 s l p)$ macrosetae; unequal claws, posterior claw 1.4-1.5 $\times$ as long as anterior claw; posterior claw with a large backward overhang (Figs 55-57); urotergite IV with $1+1$ la, $1+1(2+1)$ post macrosetae; urotergite $\mathrm{V}$ with $1+1$ la, $2+2-3+3(3+1)$ post macrosetae; urotergites VI-VII with $1+1$ la, $4+4(4+3)$ post macrosetae; urotergite VIII with $6+6$ post macrosetae; abdominal segment IX with 7+7-8+8 (8+7) post macrosetae; apical stylus setae with one or two medial thin barbs, subapical and medial setae with a few thin barbs (Fig. 58); cerci longer than body length in adult specimens (Table 5), with several whorls of long, barbed macrosetae on each article in addition to a whorl of smooth, shorter setae in distal position and a characteristic whorl of short, thin setae with a few thin distal barbs in apical position.

\section{Habitat and distribution}

Subterranean species found in a cave in Carinthia (Austria) and another one in the Kanin Mountains (Slovenia).

Plusiocampa (Plusiocampa) hoffmanni Sendra \& Paragamian sp. nov. urn:Isid:zoobank.org:act:7C4D40A0-3013-48A3-B3DF-529E78F99DDC

Figs 59-94, 204; Tables 6-8

\section{Etymology}

This species is named in honour of Luc Hoffmann (1923-2016), an extraordinary man, a naturalist and philanthropist, who helped create many international conservation organisations and supported conservation research and actions in the Mediterranean and elsewhere. 
SENDRA A. et al., Euro-Mediterranean Plusiocampinae and tachycampoid diplurans

Table 6. Plusiocampa (Plusiocampa) hoffmanni Sendra \& Paragamian sp. nov. Length of the body and antennae (measurements in $\mathrm{mm}$ ), in addition to the number of antennomeres.

\begin{tabular}{cccccc}
\hline Specimen & Depository & Locality & $\begin{array}{c}\text { Body } \\
\text { length }\end{array}$ & $\begin{array}{c}\text { No. of } \\
\text { antennomeres }\end{array}$ & $\begin{array}{c}\text { Antennal } \\
\text { length }\end{array}$ \\
\hline +, holotype & MZB & Spilaio Doxa & 5.9 & 53 & 9.3 \\
O, paratype & Coll. AS & Spilaio Sfentoni Trypa & 7.4 & 53 & telescoped \\
+, paratype & Coll. AS & Varathro Stou Bokou ton Poro & 5.9 & 46 & 7.5 \\
+, paratype & Coll. AS & Varathro Stou Bokou ton Poro & 6.1 & 53 & 8.3 \\
†, paratype & Coll. AS & Varathro Psistraki & 5.8 & 48 & 8.0 \\
¡, paratype & Coll. AS & Varathro Psistraki & 6.5 & 52 & 8.9 \\
juv., paratype & Coll. AS & Varathro Psistraki & 4.8 & 49 & 5.2 \\
\hline
\end{tabular}

\section{Material examined}

Holotype

GREECE • P; Crete, Marathos nomos Iraklion, Spilaio Doxa (n. 1065); 490 m a.s.1.; 11 May 2005; Fulvio Gasparo leg.; MZB.

\section{Paratypes}

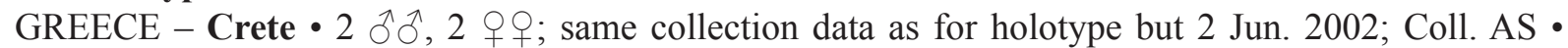
1 +; Zoniana nomos Rethymon, Spilaio Sfento Trypa (n. 701); 630 m a.s.1.; 11 Apr. 2003; Kaloust Paragamian leg.; Coll. AS • 6 q 9 ; Krousonas, Malevizi, Krousaniotiko Livadi, Varathro Stou Bokon ton Poro; 1 Jul. 1990; Kaloust Paragamian leg.; Coll. AS • 1 ; Mylopotamos, Livadia, Varathro Sipouli; 24 Mar. 1990; Kaloust Paragamian leg.; Coll. AS • 1 ภ, 2 우우 Malevizi, Gonies, Varathro Psistraki; 20 Nov. 2005; Kaloust Paragamian and S. Paragamian leg.; Coll. AS.

\section{Description}

Body. Body length: $4.8 \mathrm{~mm}$ (juvenile), 4.7 and $5.4 \mathrm{~mm}$ (males from Spilio Doxa), 5.9 and $6.4 \mathrm{~mm}$ (females from Spilio Doxa), and $7.4 \mathrm{~mm}$ (male from Sfentoni Trypa). Epicuticle smooth under optical microscope, but reticulate at high magnification (Figs 68-69); body with thin, long clothing, smooth or with a few thin distal barbs on dorsal side and well barbed on ventral side, legs and urosternal appendages.

HEAD. Antennae with 44-53 antennomeres; central antennomeres $2.5-3 \times$ as long as wide, apical antennomere $2.5 \times$ as long as wide (Fig. 61). Large cupuliform organ occupying $1 / 4$ of total length of apical antennomere, with 8-10 complex olfactory chemoreceptors (Figs 59-60). Small coniform sensillum of third antennomere located in ventral position between $c$ and $d$ macrosetae. Thin and long gouge sensilla, 38-50 $\mu \mathrm{m}$ long, in a single distal whorl of 10-14 sensilla on each medial and distal antennomere (Figs 62-64). Protruding frontal process with tubercular setae and macrosetae with thin barbs. Three macrosetae along line of insertion of antennomere and $x$ setae relatively long, covered from distal third to fourth (Figs 65-66).

Thorax. Thoracic macrosetal distribution (Fig. 67): pronotum with $1+1 m a, 4+4 l a_{1,2,3,4}, 2+2 l p_{2,3}$; mesonotum with $1+1 \mathrm{ma}, 3+3 \mathrm{la}_{1,2,3}, 2+2 l p_{2,3}, 1+1 \mathrm{mp}$; metanotum with $1+1 \mathrm{ma}, 0+0,0+1,1+1,1+2$ la or $0+1,1+1$ sla $, 2+2 l p_{2,3}, 1+1 \mathrm{mp}$. All medial posterior macrosetae in a forward position. All long, thin notal macrosetae with very thin barbs along distal third or half; marginal setae longer than clothing setae, covered by a few thin distal barbs. Legs elongated, metathoracic legs overpassing end of abdomen at beginning of tarsus. Tibia longest part of leg, $1.11-1.30 \times$ as long as tarsus and $1.21-1.37 \times$ as long 
as femur (Table 7). Ratios between lengths of tibia, tarsus and femur seem more or less fixed (Table 7). Femora II-III with one long, thin dorsal macroseta and one shorter ventral macroseta. Tibiae I-III with two or three ventral macrosetae surrounded by thin, short barbs. Calcars surrounded from base almost to tip by thin, short barbs. Metatarsus with a pseudo-articulation on distal third. Typical double rows
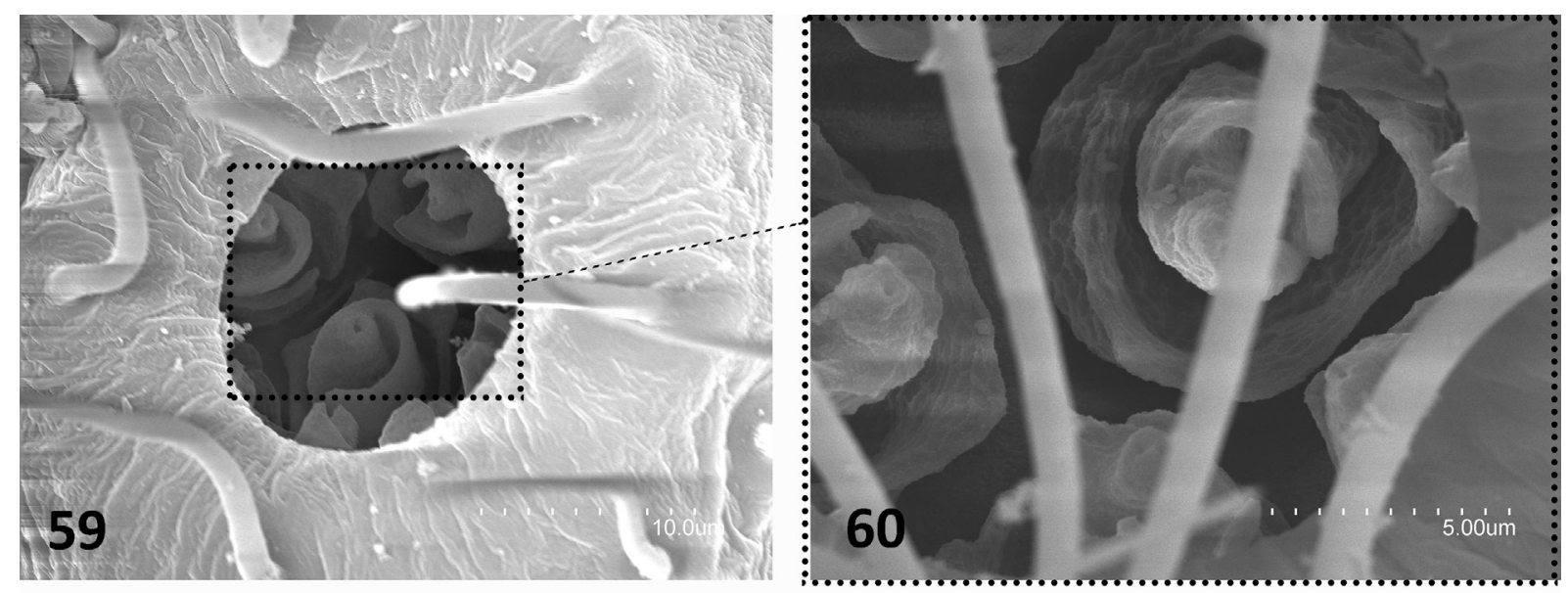

61
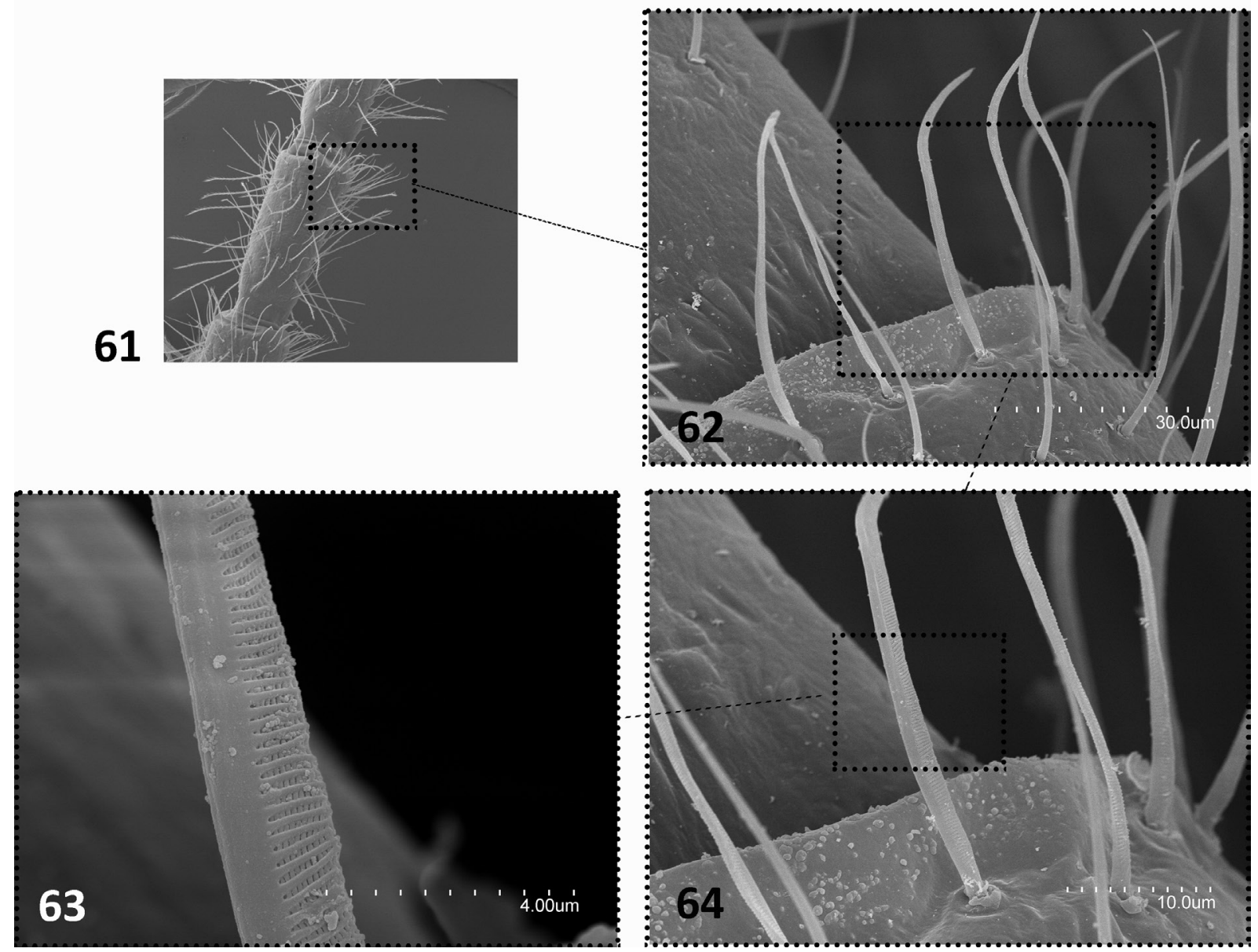

Figs 59-64. Plusiocampa (Plusiocampa) hoffmanni Sendra \& Paragamian sp. nov., from Varathro Stou Bokou ton Poro, Krousonas, Crete $(59,62-64)$ and Varathro Mythia Kabathoura, Rethymno, Crete (60-61) (Coll. AS). 59. Cupuliform organ. 60. Olfactory chemoreceptors. 61. Medial antennomere. 62. Latero-distal view of medial antennomere with gouge sensilla. 63. Gouge sensilla, detail. 64. Gouge sensilla of medial antennomere. 
Table 7. Plusiocampa (Plusiocampa) hoffmanni Sendra \& Paragamian sp. nov. Length of the body, metathoracic legs and their segments: trochanter, femur, tibia and tarsus (measurements in $\mathrm{mm}$ ).

\begin{tabular}{|c|c|c|c|c|c|c|c|c|c|}
\hline Specimen & Depository & Locality & $\begin{array}{l}\text { Body } \\
\text { length }\end{array}$ & Femur & Tibia & Tarsus & $\begin{array}{l}\text { Tibia/ } \\
\text { Femur }\end{array}$ & $\begin{array}{l}\text { Tibia/ } \\
\text { Tarsus }\end{array}$ & $\begin{array}{l}\text { Tarsus/ } \\
\text { Femur }\end{array}$ \\
\hline juv., paratype & Coll. AS & Varathro Psistraki & 3.7 & 0.70 & 0.85 & 0.75 & 1.21 & 1.13 & 1.07 \\
\hline$\widehat{\jmath}$, paratype & Coll. AS & Spilaio Doxa & 4.7 & 0.71 & 0.95 & 0.82 & 1.34 & 1.16 & 1.16 \\
\hline juv., paratype & Coll. AS & Varathro Psistraki & 4.8 & 0.8 & 1.0 & 0.9 & 1.25 & 1.11 & 1.12 \\
\hline$\hat{\jmath}$, paratype & Coll. AS & Spilaio Doxa & 5.4 & 1.15 & 1.50 & 1.17 & 1.30 & 1.28 & 1.02 \\
\hline , paratype & Coll. AS & Varathro Psistraki & 5.5 & 1.15 & 1.5 & 1.3 & 1.30 & 1.15 & 1.13 \\
\hline q, paratype & Coll. AS & Varathro Psistraki & 5.7 & 1.1 & 1.5 & 1.25 & 1.36 & 1.20 & 1.14 \\
\hline + , paratype & Coll. AS & Varathro Psistraki & 5.8 & 1.30 & 1.65 & 1.35 & 1.27 & 1.22 & 1.04 \\
\hline q, holotype & MZB & Spilaio Doxa & 5.9 & 1.19 & 1.47 & 1.21 & 1.24 & 1.22 & 1.02 \\
\hline + , paratype & Coll. AS & $\begin{array}{c}\text { Varathro Stou Bokou } \\
\text { ton Poro }\end{array}$ & 6.1 & 1.25 & 1.6 & 1.4 & 1.28 & 1.14 & 1.12 \\
\hline , paratype & Coll. AS & Spilaio Doxa & 6.4 & 1.18 & 1.62 & 1.34 & 1.37 & 1.21 & 1.14 \\
\hline$\partial$, paratype & Coll. AS & Varathro Psistraki & 6.5 & 1.35 & 1.75 & 1.35 & 1.30 & 1.30 & 1.00 \\
\hline , paratype & Coll. AS & Varathro Psistraki & 6.7 & 1.3 & 1.75 & 1.40 & 1.35 & 1.25 & 1.08 \\
\hline , paratype & Coll. AS & Varathro Sipouli & 7.4 & 1.4 & 1.75 & 1.5 & 1.25 & 1.17 & 1.07 \\
\hline
\end{tabular}

of thick, completely barbed setae along ventral side of tarsus. Dorsal and lateral subapical tarsal setae completely covered by thin barbs nearly from base almost to tip. Subequal to slightly unequal claws (posterior claw 1.05-1.15 $\times$ as long as anterior one), with large lateral crests well developed on posterior claw prolongated backwards. Ventral side of claws with longitudinal ridges separated by a surface of micro-hemispherical structures. Pretarsal processes setiform, with abundant, very short proximal barbs (Figs 71-82).

Abdomen. Distribution of abdominal macrosetae on tergites: $1+1$ post $_{1}$ on I-II; $1+1-0+0$ la, $1+1$ post $_{1}$ on III; $1+1$ la, $3+3-4+4$ post $_{1,2,4,5}$ on IV; $1+1$ la, 5+5 post ${ }_{1-5}$ on V-VII, 7+7 post on VIII; 8+8-9+9 post on abdominal segment IX. Urosternite I with $7+7-9+9$, urosternites II-VII with 5+5-7+7, urosternite VIII with $2+2$ macrosetae; all urosternal macrosetae robust, large, covered by long barbs along distal half to four-fifths (Figs 87-88). Stylus with subapical setae longer and more barbated, in fact completely
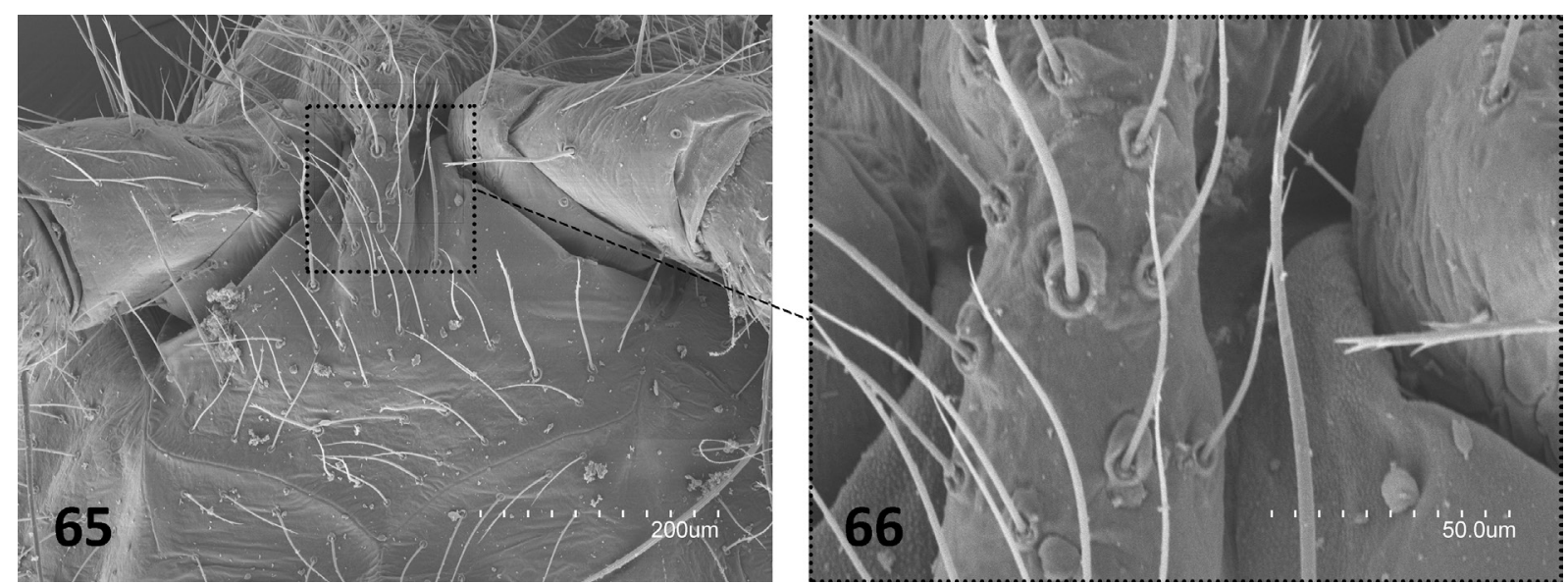

Figs 65-66. Plusiocampa (Plusiocampa) hoffmanni Sendra \& Paragamian sp. nov., from Varathro Stou Bokou ton Poro, Krousonas, Crete (Coll. AS). 65. Frontal process. 66. Anterior zone of frontal process. 
surrounded by short, abundant barbs, more numerous on apical and ventromedial setae (Figs 92-93); large eversible vesicles (Figs 92, 94). Two complete cerci, 2.37 and $1.71 \times$ as long as body; this ratio higher in an incomplete $14.50 \mathrm{~mm}$ long cercus of $5.4 \mathrm{~mm}$ long male (Table 8); up to 11 articles, covered

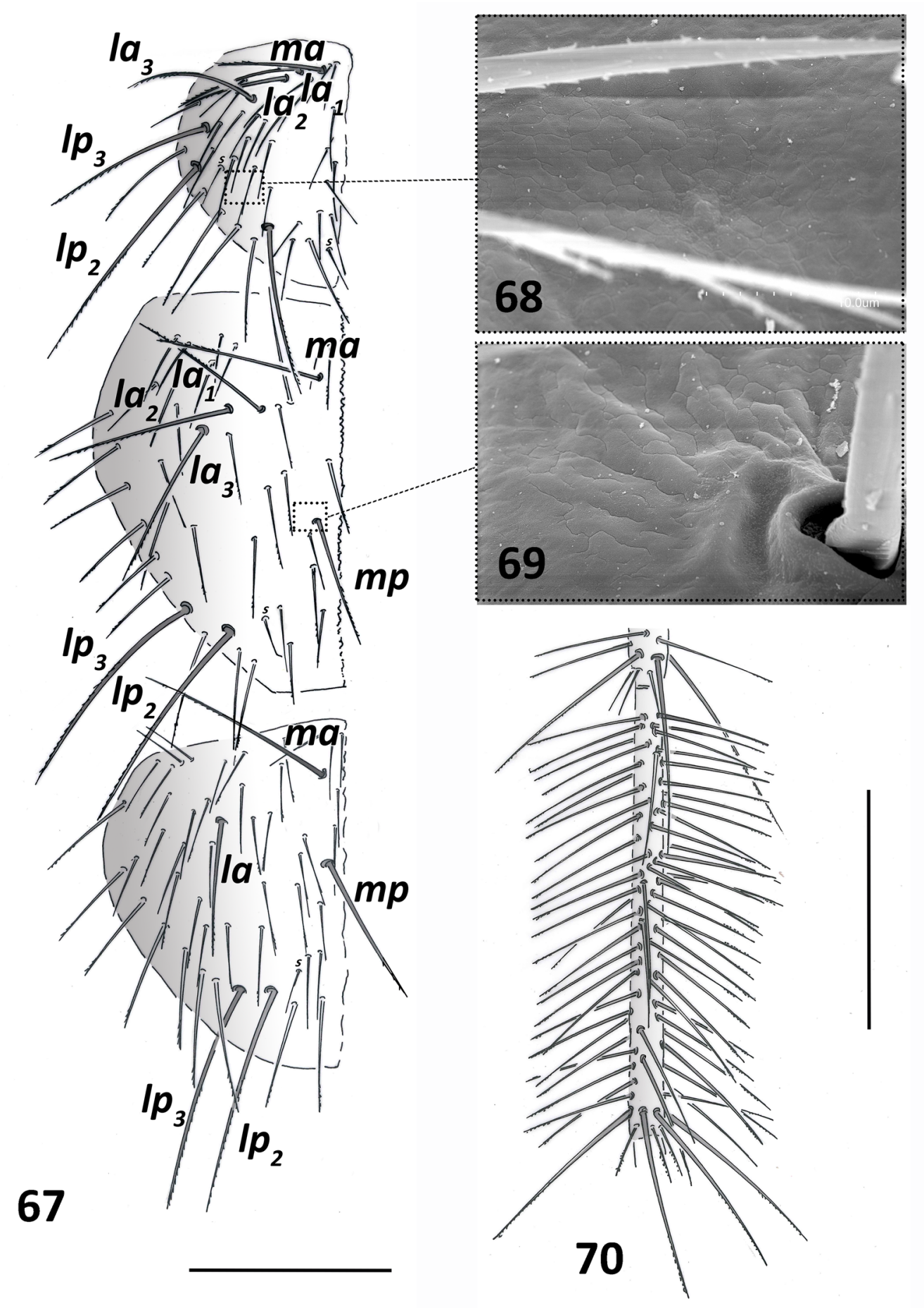

Figs 67-70. Plusiocampa (Plusiocampa) hoffmanni Sendra \& Paragamian sp. nov. 67, 70. Paratype, ô, $5.4 \mathrm{~mm}$ long, from Spilaio Doxa, Marathos, Irakleo Prefecture, Crete (MZB). 68-69. Specimen from Varathro Mythia Kabathoura, Rethymno, Crete (Coll. AS). 67. Pronotum, mesonotum and metanotum, left side. 68. Surface of pronotum. 69. Surface of mesonotum. 70. Fourth cercal article. Scale bars: $67=0.4 \mathrm{~mm} ; 70=0.5 \mathrm{~mm}$. 
with numerous disorganized, long, thin macrosetae with thin barbs along distal half, in addition to a distal whorl of longer, thicker macrosetae on each article plus an apical whorl of barbed, thin, short clothing setae (Fig. 70).
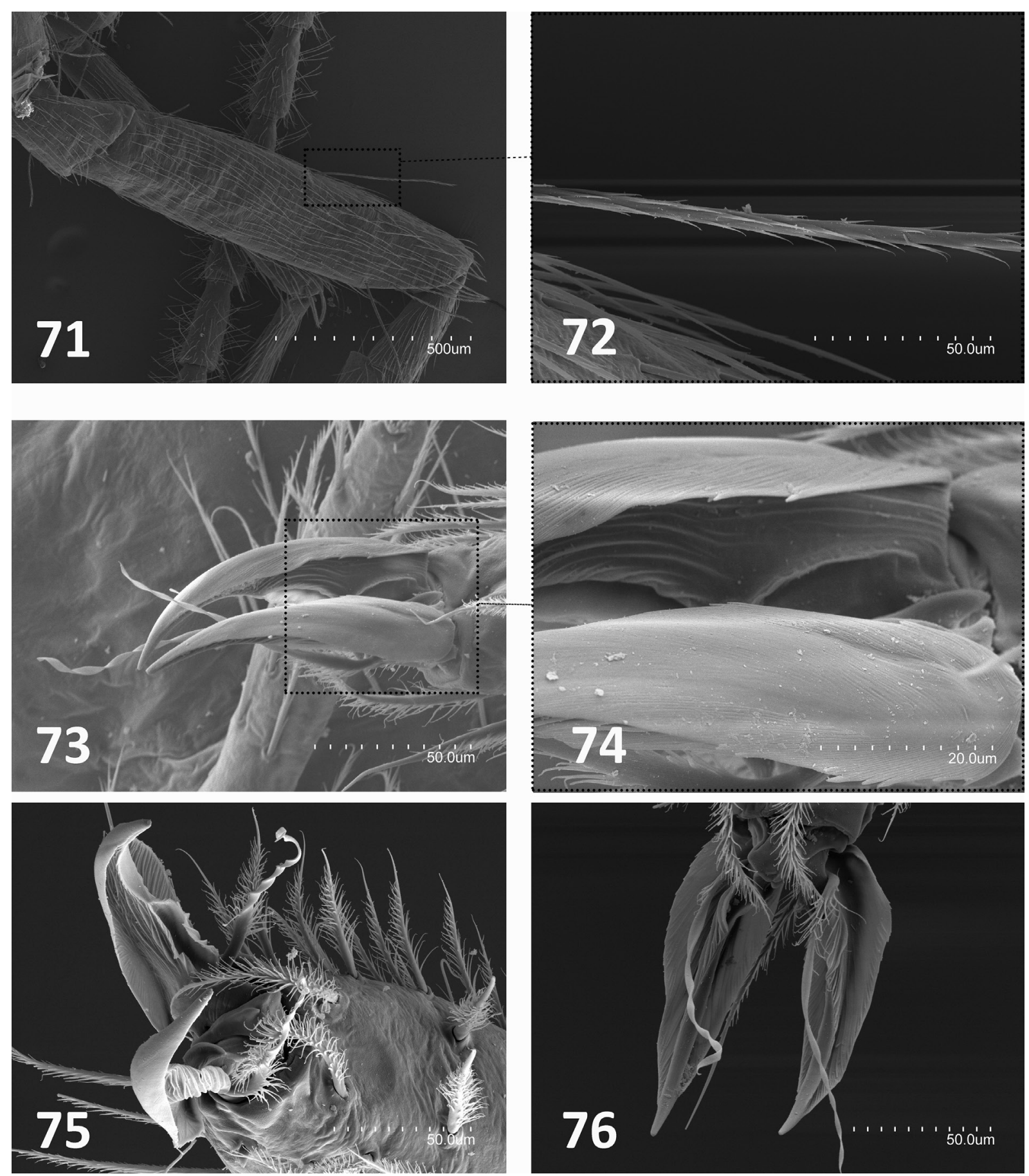

Figs 71-76. Plusiocampa (Plusiocampa) hoffmanni Sendra \& Paragamian sp. nov., from Varathro Stou Bokou ton Poro, Krousonas, Crete (71-74) and Varathro Mythia Kabathoura, Rethymno, Crete (75-76) (Coll. AS). 71. Femur of metathoracic leg. 72. Dorsal femoral macroseta, metathoracic leg. 73. Dorsolateral view of pretarsus, posterior claw in the foreground. 74. Detail of preceding, posterior claw in the foreground. 75. End of tarsus, with pretarsus in ventral view. 76. Pretarsus, ventral view. 
SeCONDARY SEX ChARACTERs. Female urosternite I with subcylindrical appendages, each bearing up to 18 glandular $a_{1}$ setae in a distal area (Figs 89-91). Male urosternite I (Figs 83-86) with a posterior area of up to 160 glandular $g_{l}$ setae in larger male from Sfedoni Trypa (absent in smaller male); with
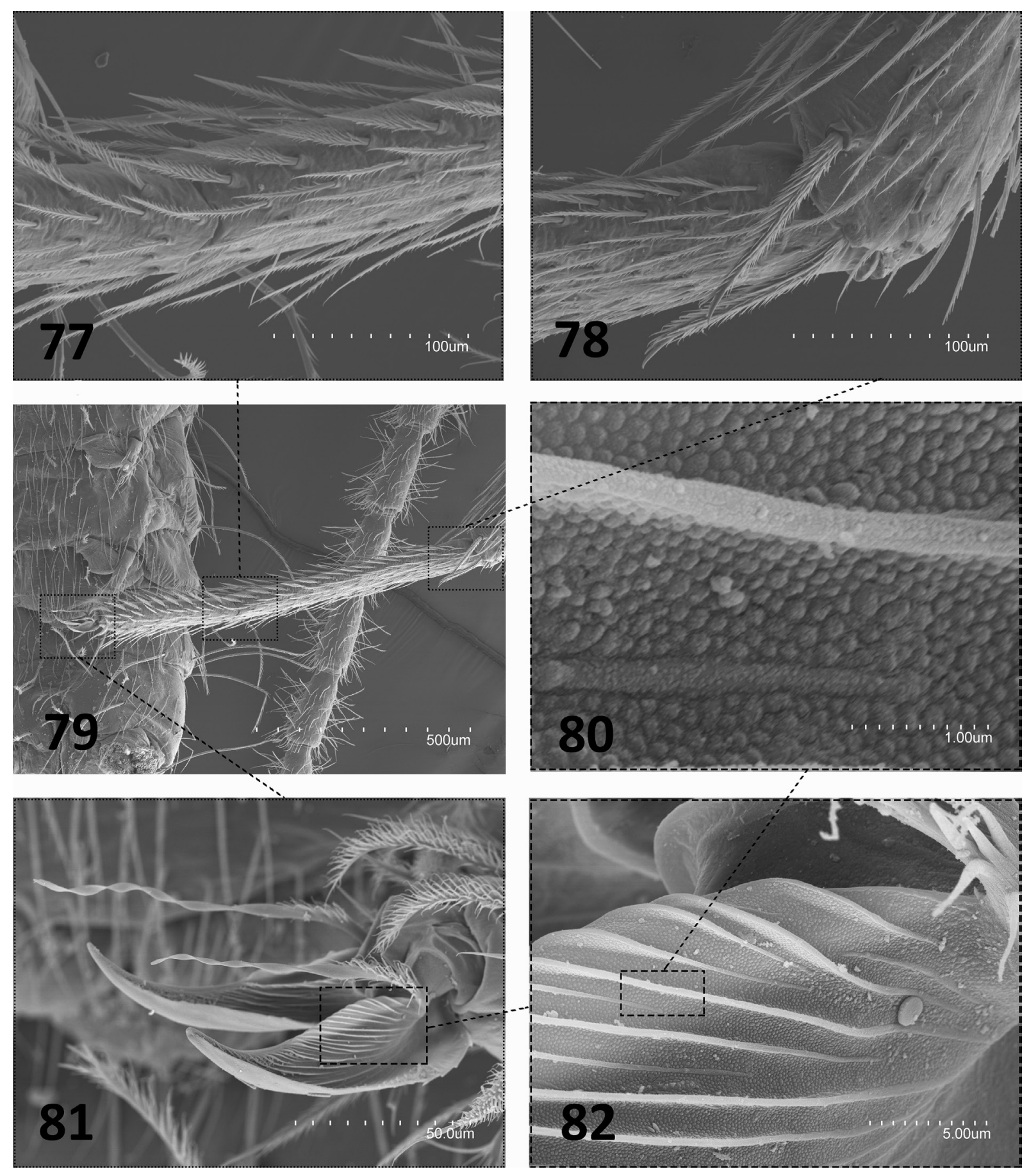

Figs 77-82. Plusiocampa (Plusiocampa) hoffmanni Sendra \& Paragamian sp. nov., metathoracic leg of $q$ from Varathro Stou Bokou ton Poro, Krousonas, Crete (Coll. AS). 77. Medial portion of tarsus in latero-ventral view, with a visible pseudo-articulation. 78. Joint between tibia and tarsus with their calcars. 79. Tarsus. 80. Detail of ventral side of anterior claw, lateral view. 81. Pretarsus, lateral anterior view. 82. Anterior claw, detail. 
thick, large, subcylindrical appendages, much thicker than female appendages, each bearing up to 100 glandular $a_{1}$ setae in a large distal area in two largest adults. Spermatozoid fascicles with a thick spiral filament.
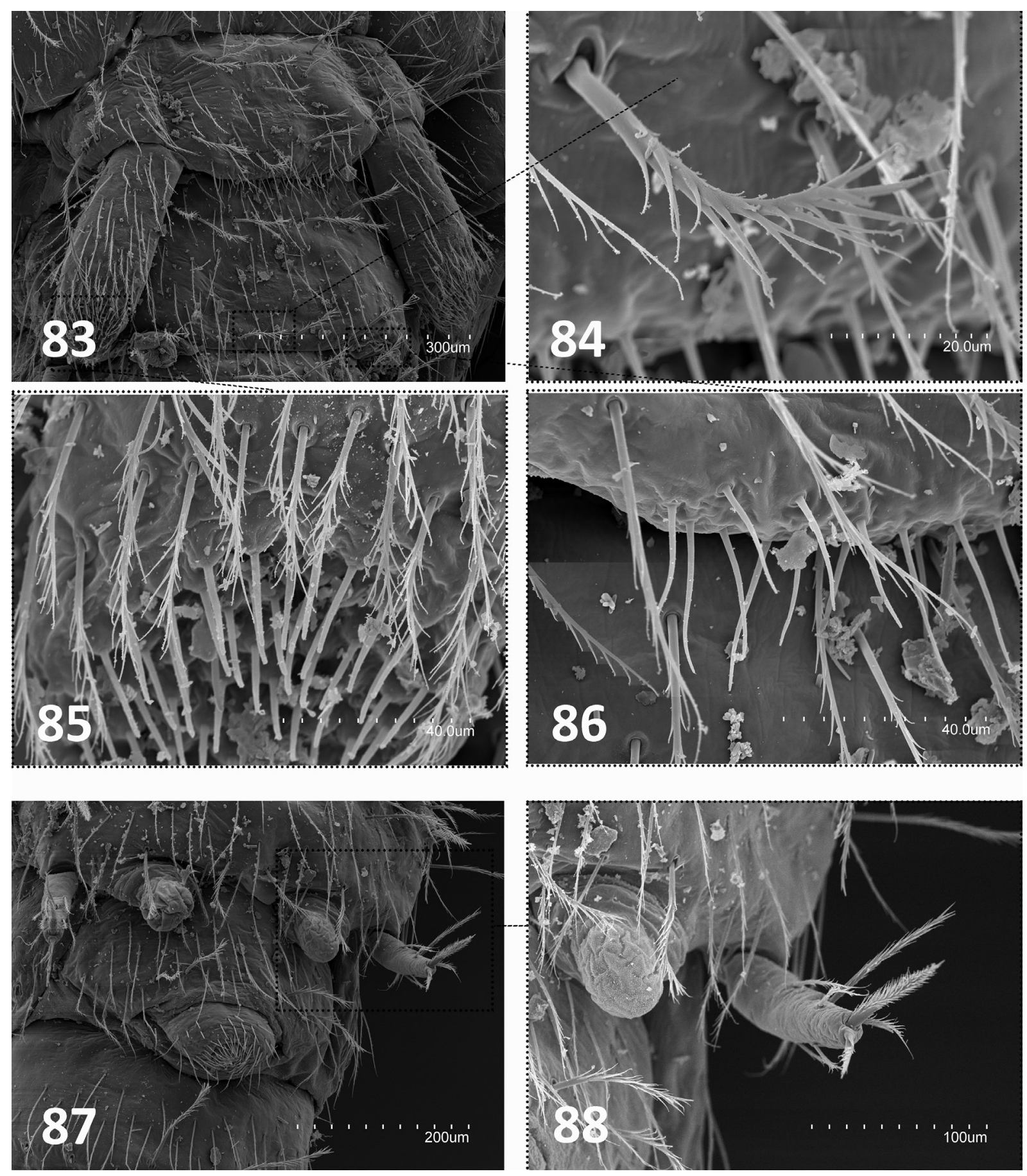

Figs 83-88. Plusiocampa (Plusiocampa) hoffmanni Sendra \& Paragamian sp. nov., ô, from Varathro Mythia Kabathoura, Rethymno, Crete (Coll. AS). 83. Urosternites I-II. 84. Macroseta on posterior portion of urosternite I. 85. Tip of urosternal appendage. 86. Latero-interior portion of posterior edge, with glandular $g_{l}$ setae. 87. Urosternites VII-IX. 88. Left latero-posterior portion of urosternite VII. 


\section{Phyletic affinities, habitat and distribution}

The presence of medial posterior macrosetae on the mesonotum and metanotum relates $P$. (P.) hoffmanni sp. nov. to almost half of the species in the subgenus Plusiocampa, all living in the European region, including most of the Mediterranean islands. Among them, $P(P)$ festae is probably the closest related species due to the distribution pattern of their notal macrosetae; in spite of the fact that both species live
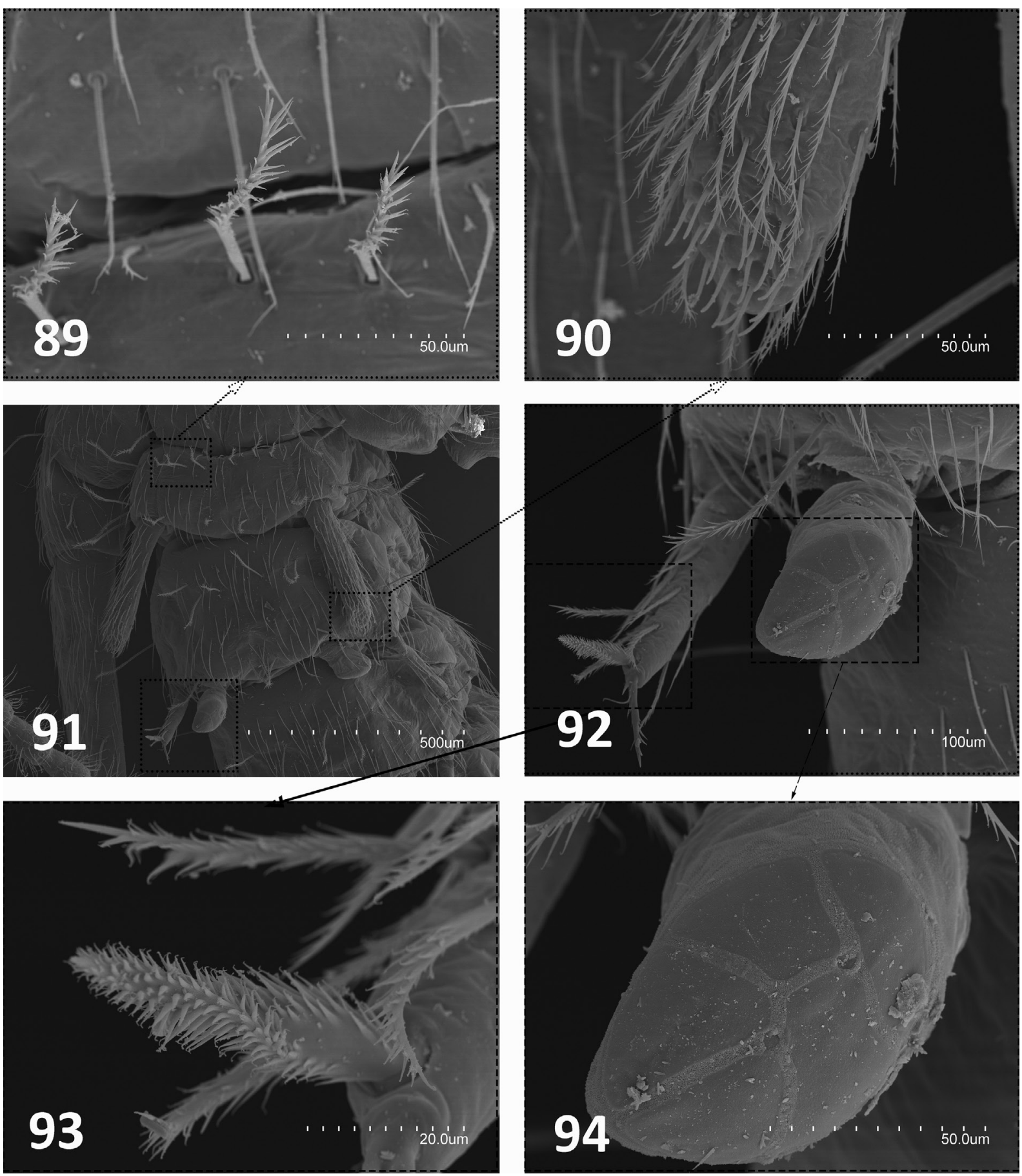

Figs 89-94. Plusiocampa (Plusiocampa) hoffmanni Sendra \& Paragamian sp. nov., $q$, from Varathro Stou Bokou ton Poro, Krousonas, Crete (Coll. AS). 89. Macrosetae on anterior portion of urosternite I. 90. Distal portion of an appendage on urosternite I. 91. Urosternites I-II. 92. Stylus and abdominal eversible vesicle. 93. Detail of a stylus with subapical seta. 94. Abdominal eversible vesicle, detail. 
Table 8. Plusiocampa (Plusiocampa) hoffmanni Sendra \& Paragamian sp. nov. Length of the body, cerci and their articles (measurments in $\mathrm{mm}$ ).

\begin{tabular}{|c|c|c|c|c|c|c|c|c|c|c|c|c|c|c|c|c|}
\hline Specimen & $\begin{array}{l}\text { Deposi- } \\
\text { tory }\end{array}$ & Locality & $\begin{array}{l}\text { Body } \\
\text { length }\end{array}$ & Base & $1^{\text {st }}$ & $2^{\text {nd }}$ & $3^{\text {rd }}$ & $4^{\text {th }}$ & $5^{\text {th }}$ & $6^{\text {th }}$ & $7^{\text {th }}$ & $8^{\text {th }}$ & $9^{\text {th }}$ & $10^{\text {th }}$ & $11^{\text {th }}$ & Total \\
\hline$\delta$, paratype & Coll. AS & $\begin{array}{l}\text { Spilaio } \\
\text { Doxa }\end{array}$ & 5.4 & 1.1 & 0.6 & 0.7 & 0.9 & 1.0 & 1.3 & 1.5 & 1.9 & 2.1 & 2.4 & incompl. & - & 14.50 \\
\hline †, paratype & Coll. AS & $\begin{array}{l}\text { Varathro } \\
\text { Psistraki }\end{array}$ & 6.7 & 2.4 & 0.6 & 0.7 & 0.8 & 0.85 & 0.9 & 0.95 & 1.1 & 1.5 & 1.9 & 1.95 & 2.2 & 15.85 \\
\hline, paratype & Coll. AS & $\begin{array}{c}\text { Varathro } \\
\text { Sipouli }\end{array}$ & 7.4 & 1.1 & 0.75 & 0.8 & 1.15 & 1.35 & 1.95 & 2.35 & 3.2 & - & - & - & - & 12.65 \\
\hline
\end{tabular}

in Crete (Condé 1984a; Silvestri 1933a), they occupy different habitats, $P$. (P.) hoffmanni sp. nov. in deep subterranean habitats, $P$. (P.) festae in soil and subterranean superficial habitats. In addition to this ecological difference, there are several important features that allow them to be separated. Plusiocampa $(P$.$) hoffmanni sp. nov. has troglomorphic traits, with longer appendages than P$. (P.) festae and more antennomeres and cercal articles, with more complex and more numerous olfactory chemoreceptors within the cupuliform organ. In $P$. (P.) hoffmanni sp. nov., the claws are slightly unequal to subequal, but with large lateral crests and a backward prolongation of the posterior claws. Additionally, $P .(P$. hoffmanni sp. nov. shows a protruding frontal process covered by tuberculated setae, $8+8$ macrosetae on the first urosternite and $6+6$ on the second to seventh urosternites. Some of these features also separate $P$. (P.) hoffmanni sp. nov. from $P$. (P.) rybaki, a poorly described troglomorphic species from the southern Balkan Peninsula (Condé 1956). Plusiocampa (P.) hoffmanni sp. nov. has been collected from the deep zone of 14 caves in the numerous karst areas of Crete (Fig. 204).

\section{Plusiocampa (Plusiocampa) humicola Ionescu, 1951}

Plusiocampa humicola Ionescu, 1951: 528, figs 1-6.

Diagnosis (Ionescu 1951; Sendra et al. 2012b)

Non-troglomorphic species. Antennae with 21-23 doliiform antennomeres; four or five olfactory chemoreceptors; frontal process without non-tubercular setae. Pronotum with $1+1 \mathrm{ma}, 3+3 \mathrm{la}, 2+2 \mathrm{lp}$ macrosetae; mesonotum with $1+1 \mathrm{ma}, 3+3 \mathrm{la}, 2+2 \mathrm{lp}, 1+1 \mathrm{mp}$ macrosetae; metanotum with $1+1 \mathrm{ma}, 1+1$ la, 2+2 lp , 1+1 $\mathrm{mp}$ macrosetae; long, barbed notal macrosetae. Two ventral tibial macrosetae; slightly unequal claws (1.1-1.2) with large lateral crests, posterior claw without backward overhang. Urotergites I-II with $1+1$ post macrosetae; urotergite III with $2+2$ post macrosetae; urotergite IV with $1+1$ la, $4+4$ post macrosetae; urotergite $\mathrm{V}$ with $1+1$ la, $5+5$ post macrosetae; urotergites VI-VII with $2+2$ la, $5+5$ post macrosetae; urotergite VIII with $6+6$ post macrosetae; abdominal segment IX with $8+8$ post macrosetae; urosternite I with $7+7$, urosternites II-VII with $5+5$, urosternite VIII with $2+2$ macrosetae. Male without glandular $g_{1}$ setae; subcylindrical appendages with glandular $a_{1}$ setae. Appendages of female slightly thinner, subcylindrical, with glandular $a_{l}$ setae.

\section{Habitat and distribution}

Soil-dwelling species found at four sites around the South Carpathian Mountains, including the Transylvanian reliefs, Romania.

Plusiocampa (Plusiocampa) hystricula Bareth \& Condé, 1984

Plusiocampa hystricula Bareth \& Condé, 1984: 133, fig. 1. 
Diagnosis (Bareth \& Condé 1984)

Troglomorphic species. Antennae with 31 antennomeres (regenerated antenna); frontal process with non-tubercular setae. Pronotum with $1+1 \mathrm{ma}, 3+3 \mathrm{la}, 2+2 \mathrm{lp}$ macrosetae; mesonotum with $1+1 \mathrm{ma}$, $3+3$ la $, 2+2 l p, 1+1 \mathrm{mp}$ macrosetae; metanotum with $1+1 \mathrm{ma}, 2+2$ la $, 2+2 \mathrm{lp}, 1+1 \mathrm{mp}$ macrosetae; long, barbed notal macrosetae; abundant notal clothing setae. Two ventral tibial macrosetae; slightly unequal claws (1.2) with large lateral crests, posterior claw with a small backward overhang. Urotergite I with $2+2$ post macrosetae; urotergite II with $2+3$ post macrosetae; urotergite III with $3+3$ post macrosetae; urotergite IV with $1+1$ la, $5+5$ post macrosetae; urotergites $\mathrm{V}-\mathrm{VII}$ with $3+3$ la, $5+5$ post macrosetae; urotergite VIII with $7+7$ post macrosetae; abdominal segment IX with $9+9$ post macrosetae; urosternite I with $7+7$, urosternites II-VII with $5+5$, urosternite VIII with $2+2$ macrosetae. Male unknown; female with subcylindrical appendages bearing glandular $a_{1}$ setae.

\section{Habitat and distribution}

Subterranean species, found only in Bus de Bec Cave, Brescia, Italian Alps.

\section{Plusiocampa (Plusiocampa) isterina Condé, 1993}

Plusiocampa isterina Condé, 1993a: 736, figs 1a, 2, 3a, 4, 6 a.

Diagnosis (Condé 1993a, 1996)

Non-troglomorphic species. Antennae with 23 antennomeres; four simple olfactory chemoreceptors in cupuliform organ; slightly protruding frontal process with some slightly tubercular setae. Pronotum with $1+1 \mathrm{ma}, 3+3$ la, $2+2$ lp macrosetae; mesonotum with $1+1 \mathrm{ma}, 3+3 \mathrm{la}, 2+2 \mathrm{lp}$ macrosetae; metanotum with $1+1 \mathrm{ma}, 1+1(2+1) l a, 2+2$ lp macrosetae; long, thin, barbed notal macrosetae; short, smooth clothing setae. Two ventral tibial macrosetae; unequal claws (1.29) with large lateral crests, posterior claw with a backward overhang; pretarsal processes short, with a few sparse barbs. Urotergites I-II with $1+1$ post macrosetae; urotergite III with $2+2$ post macrosetae; urotergites IV-V with $1+1$ la, $5+5$ post macrosetae; urotergites VI-VII with $2+2$ la, $5+5$ post macrosetae; urotergite VIII with $6+6$ post macrosetae; abdominal segment IX with $8+8$ post macrosetae; urosternite I with $7+7$, urosternites IIVII with 5+5, urosternite VIII with $2+2$ macrosetae. Male unknown; subcylindrical female appendages bearing glandular $a_{1}$ setae.

\section{Plusiocampa (Plusiocampa) aff. isterina Condé, 1993}

\section{Differential diagnosis against the type form}

This record is based on seven specimens found in Ledenjača Cave, Bosnia and Herzegovina (see Table $\mathrm{S} 2$ in Supplementary Material). Due to their clear differences from the type of $P$. (P.) isterina, described from Movile Cave, they have been identified as $P$. $(P$.) aff. isterina. Specimens from Ledenjača Cave have a higher number of antennomeres (25-28), six olfactory chemoreceptors in a relatively large cupuliform organ (occupying one third of a short antennomere) and a clearer protruding frontal process with remarkable tuberculate setae.

\section{Habitat and distribution}

Non-troglomorphic species. The nominate form is found in Peştera Movile Cave, Southern Dobruja, Romania. The aff. form is found in a cave in the Dinaric Mountains, Bosnia and Hercegovina. 
Plusiocampa (Plusiocampa) lagari Sendra \& Condé, 1987

Figs 95-118, 203

Plusiocampa lagari Sendra \& Condé, 1987: 741, figs 1-4, tables 1-3.

Diagnosis (Sendra \& Condé 1987; Sendra 2001; Sendra et al. 2004)

Troglomorphic species. Antennae with 32-34 antennomeres; 15-18 complex olfactory chemoreceptors in cupuliform organ; slightly protruding frontal process with non-tubercular setae. Pronotum with 1+1
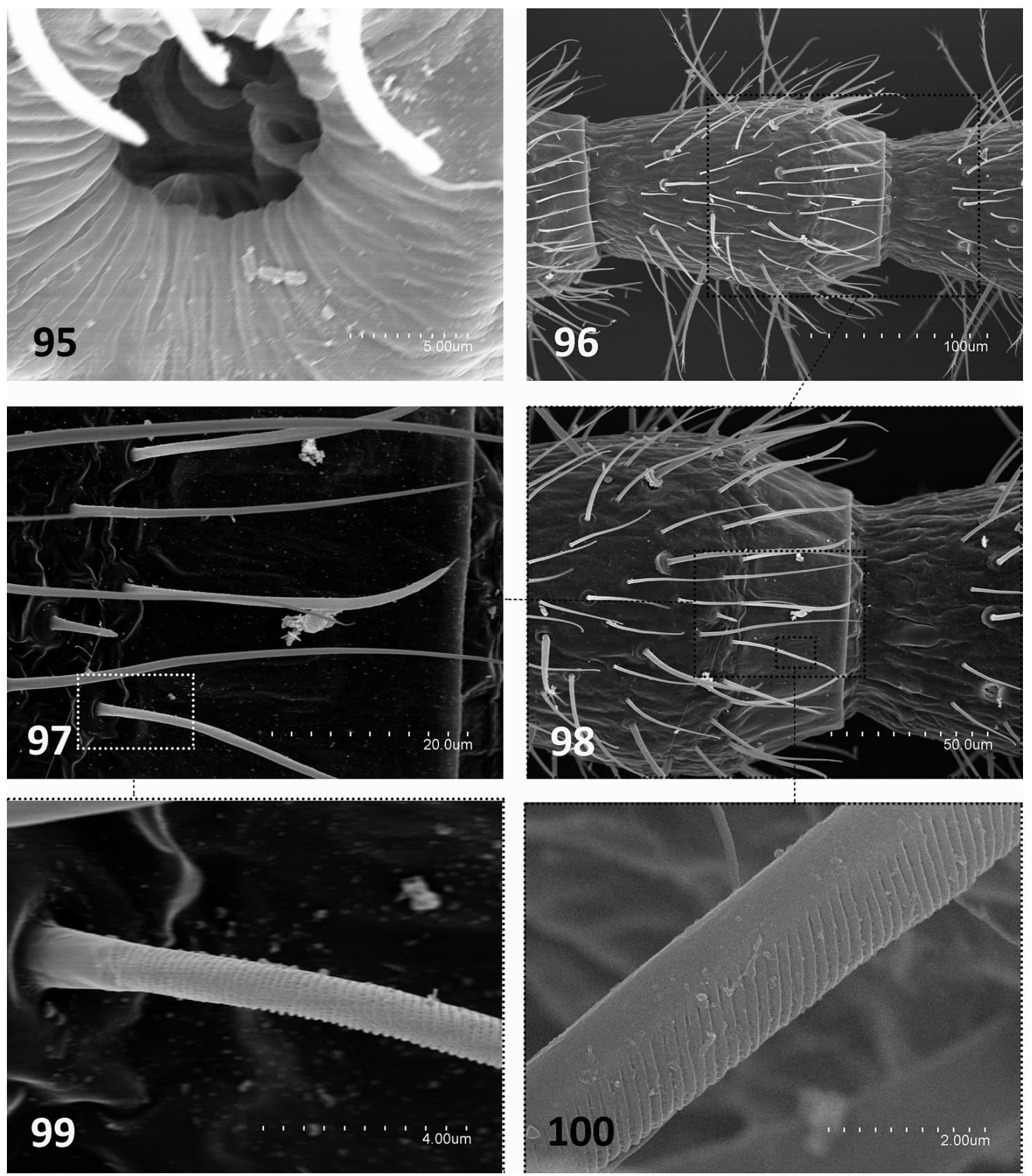

Figs 95-100. Plusiocampa (Plusiocampa) lagari Sendra \& Condé, 1987, from Chorros Cave, Riopar, Albacete, Spain (Coll. AS). 95. Cupuliform organ. 96. Medial antennomere. 97. Gouge and coniform sensilla. 98. Medial antennomere, detail with gouge and coniform sensilla. 99. Base of gouge sensillum, detail. 100. Medial portion of gouge sensillum, detail. 
$m a, 3+3(4+3) l a, 2+2$ lp macrosetae; mesonotum with $1+1 m a, 2+2 l a, 2+2 l p, 1+1 \mathrm{mp}$ macrosetae; metanotum with $1+1 m a, 1+1 l a, 2+2 l p(1+1 l p$ supplementary in some populations), $1+1 \mathrm{mp}$ macrosetae. Two or three ventral tibial macrosetae; subequal claws (1.1) with large lateral crests, posterior claw with a small backward overhang. Urotergites I-III with $1+1$ post macrosetae; urotergite IV with $1+1$ la, $2+2-3+3-4+3$ post macrosetae; urotergites V-VII with $1+1$ la, $5+5(4+5)$ post macrosetae; urotergite
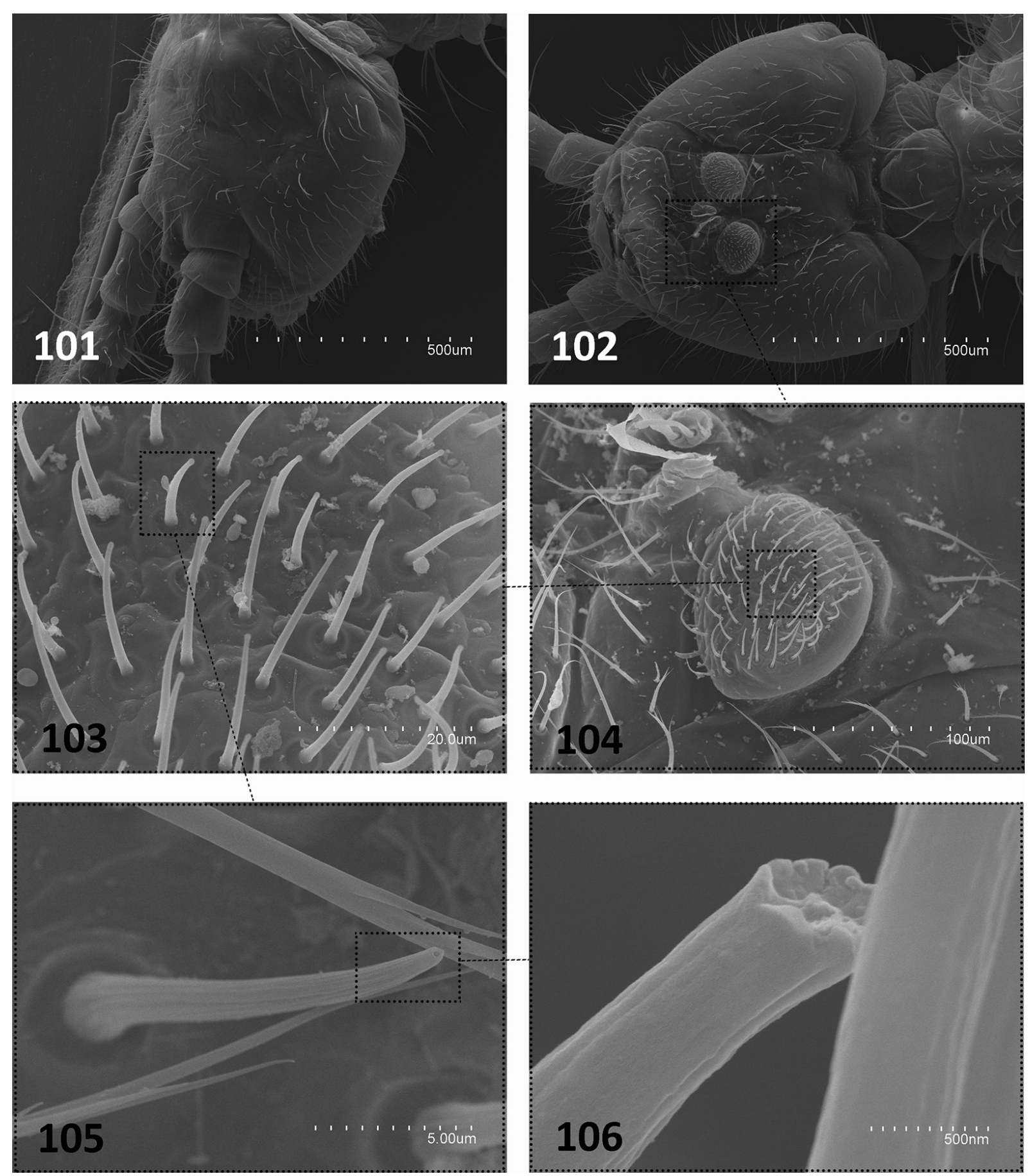

Figs 101-106. Plusiocampa (Plusiocampa) lagari Sendra \& Condé, 1987, from Chorros Cave, Riopar, Albacete, Spain (Coll. AS). 101. Head, dorso-lateral view. 102. Head, ventral view. 103. Detail of labial palp. 104. Labial palp. 105. Neuroglandular seta. 106. Tip of neuroglandular seta. 
VIII with $6+6(6+5,6+7)$ post macrosetae; abdominal segment IX with $8+8(8+9)$ post macrosetae; urosternite I with $7+7$, urosternites II-VII with $5+5$, urosternite VIII with $2+2$ macrosetae. Male with a narrow area of glandular $g_{1}$ setae, subclylindrical appendages with glandular $a_{1}$ setae; female with subcylindrical appendages bearing glandular $a_{1}$ setae. Spermatozoid fascicle wheels with $1 \frac{1}{2}$ turns of $110-140 \mu \mathrm{m}$ long and $6 \mu \mathrm{m}$ wide filament.
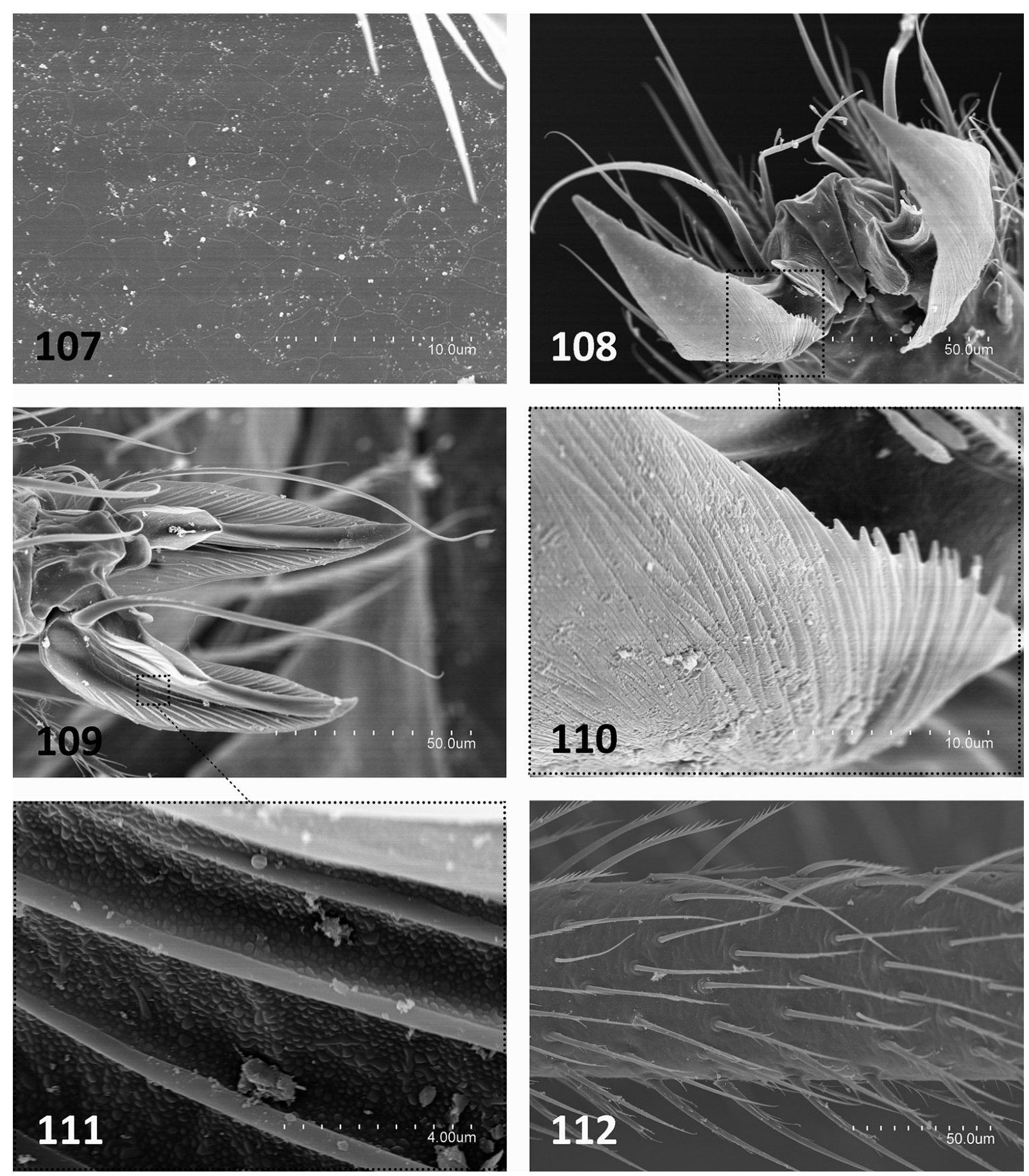

Figs 107-112. Plusiocampa (Plusiocampa) lagari Sendra \& Condé, 1987, from Chorros Cave, Riopar, Albacete, Spain (Coll. AS). 107. Surface of metanotum, detail. 108. Pretarsus, frontal-dorsal view. 109. Pretarsus, ventral view. 110. Lateral crest of posterior claw, detail. 111. Lateral crest, ventral view, detail. 112. Portion of medial tarsus. 


\section{Remarks}

Ten specimens from the Chorros and Farallón Caves in Riopar, Albacete, Spain (see Table S2 in Supplementary Material) were used for SEM to study some features that are difficult to observe under an optical microscope. Epicuticle slightly reticulate, with large polygonal pattern (Fig. 107); antennomeres
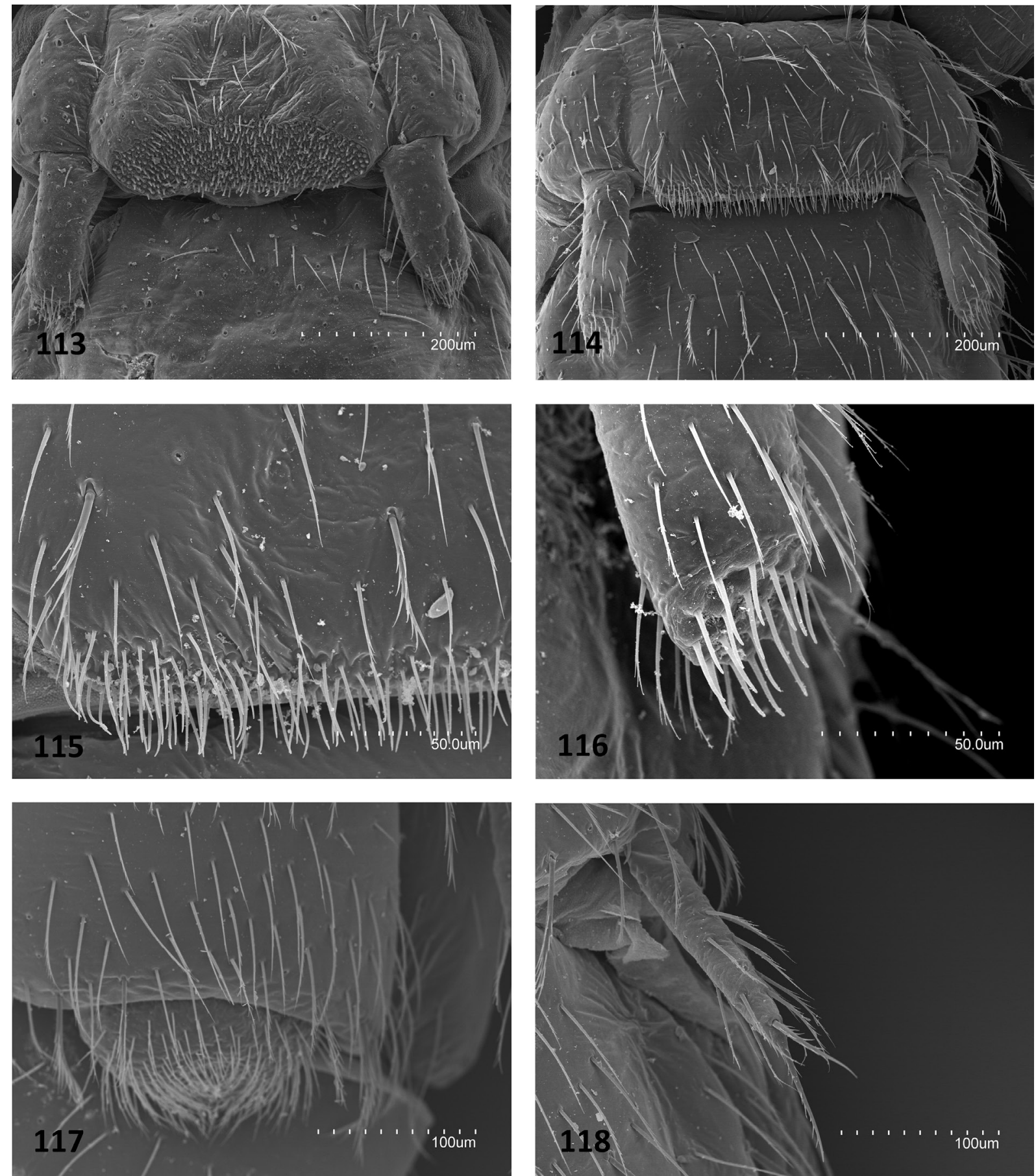

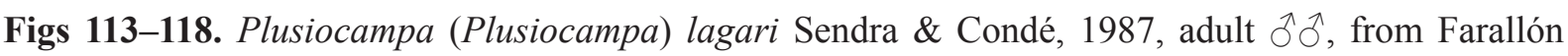
Cave, Riopar, Albacete, Spain (Coll. AS). 113. Urosternite I of a large adult $\widehat{\partial}$. 114. Urosternite I. 115. Distal portion of appendage of a urosternite. 116. Detail of posterior portion of urosternite I with glandular $g_{1}$ setae. 117. Urosternite VIII. 118. Lateral part of urosternite VII, with stylus. 
with a whorl of thin gouge sensilla, 34-36 $\mu \mathrm{m}$ long, with an external transversal striped surface (Figs 96-100). Cupuliform organ with spheroidal olfactory chemoreceptors in a complex spiral shape (Fig. 95). Head suboval with slightly protruding frontal process (Figs 101-102). Labial palp with short neuroglandular setae (Figs 103-106). Tarsus with two ventral barbed rows (Fig. 112). Claws with large lateral crest with dorsal striated surface and with ventral longitudinal grooves separated by a multihemispherical surface (Figs 108-111). Male with a large area of glandular $g_{l}$ setae and slightly thicker subcylindrical appendages (Figs 113-117). Stylar setae covered by a few thin, short barbs (Fig. 118).

\section{Habitat and distribution}

Subterranean species found in 31 caves in the external zone of the Baetic Mountain Range, around the carbonate areas of the Cazorla, Segura, Alcaraz and Castril Mountains and the peripheral karst areas of Filabres Mountain and the Yesos de Sorbas, southeastern Iberian Peninsula (Fig. 203).

Plusiocampa (Plusiocampa) lagoi Silvestri, 1932

Plusiocampa lagoi Silvestri, 1932: 78, figs xiii-xiv.

\section{Diagnosis (Silvestri 1932a)}

Non-troglomorphic species. Antennae with 23-26 antennomeres; non-protruding frontal process with simple setae. Pronotum with $1+1 \mathrm{ma}, 4+4 l a, 2+2 l p$ macrosetae; mesonotum with $1+1 \mathrm{ma}, 3+3 \mathrm{la}$, $2+2 l p, 1+1 \mathrm{mp}$ macrosetae; metanotum with $1+1 \mathrm{ma}, 1+1 \mathrm{la}, 2+2 \mathrm{lp}, 1+1 \mathrm{mp}$ macrosetae; long, barbed notal macrosetae. Two ventral tibial macrosetae; subequal claws (1.05) with large lateral crests without prolonged backward overhang. Urotergites I-II with $1+1$ post macrosetae; urotergite III with $2+2$ post macrosetae; urotergite IV with $1+1$ la, $5+5$ post macrosetae; urotergites $\mathrm{V}-\mathrm{VII}$ with $3+3$ la, $5+5$ post macrosetae; urotergite VIII with $7+7$ post macrosetae; urosternite I with $8+8$, urosternite II-VII with $5+5$, urosternite VIII with $2+2$ macrosetae.

Plusiocampa (Plusiocampa) aff. lagoi Silvestri, 1932

\section{Differential diagnosis against the type form}

One female and two juveniles (Coll. AS) collected in a couple of Croatian caves (see Table S2 in Supplementary Material) show several differences from the type form in: the non-troglomorphic shape; antennae with 24 antennomeres and four simple olfactory chemoreceptors; the number of urotergal macrosetae, with $1+1$ post macrosetae on urotergite III, $6+6$ post macrosetae on urotergite VIII and $8+8$ post macrosetae on abdominal segment IX; and a unique ventral tibial macroseta.

\section{Habitat and distribution}

Hypogean species found in edaphic habitats. The nominate form is known from a couple of localities in Marizza and Cremastò, Ródos, Greece. The aff. form was found in two caves in the Dinaric Mountains.

\section{Plusiocampa (Plusiocampa) latens Condé, 1948}

Plusiocampa latens Condé, 1948d: 49, fig. 1.

\section{Diagnosis (Condé 1948d)}

Slightly troglomorphic species. Antennae with 24-27 with antennomeres. Small protruding frontal process with slightly tuberculated setae. Pronotum with $1+1 m a, 3+3 l a, 2+2 l p$ macrosetae; mesonotum with $1+1 m a, 3+3 l a, 2+2 l p$ macrosetae; metanotum with $1+1 m a, 1+1 l a, 2+2 l p$ macrosetae; long, barbed notal macrosetae. Two ventral tibial macrosetae; unequal claws (1.4) with large lateral crests, posterior claw with a backward overhang. Urotergites I-III with $1+1$ post macrosetae; urotergite IV 
with $1+1$ la, $3+3$ post macrosetae; urotergites $\mathrm{V}-\mathrm{VII}$ with $1+1$ la, $5+5$ post macrosetae; urotergite VIII with $6+6$ post macrosetae; abdominal segment IX with $8+8$ post macrosetae; urosternite I with $7+7$, urosternites II-VII with $5+5$, urosternite VIII with $2+2$ macrosetae. Male with glandular $g_{1}$ setae, subcylindrical appendages with glandular $a_{1}$ setae; female and male appendages identical.

\section{Remarks}

Among the studied material there is a male from Žira jama and another male from Crnulja ponor from Bosnia and Herzegovina (see Table S2 in Supplementary Material) which match the original description and allowed the completion of the previous diagnosis (Coll. AS).

Plusiocampa (Plusiocampa) aff. latens Condé, 1948

\section{Differential diagnosis against the type form}

One male and one female from Vidovića špilja, Croatia (see Table S2 in Supplementary Material) show notable differences compared to the type form. Antennae with 25 doliiform antennomeres; nontubercular setae on simple frontal process. Pronotum with $1+1 \mathrm{sma}, 1+1 \mathrm{ma}, 3+3 \mathrm{la}, 2+2 \mathrm{lp}$ macrosetae; mesonotum with $1+1 m a, 3+3 l a, 2+2 l p$ macrosetae; metanotum with $1+1 m a, 1+1 l a, 2+2 l p$ macrosetae. Urotergites I-II with $1+1$ post macrosetae; urotergite III with $2+2$ post macrosetae; urotergite IV with $0+1$ la $4+4-5+5$ post macrosetae; urotergite $\mathrm{V}$ with $1+1$ la, $5+5$ post macrosetae; urotergites VI-VII with $2+2$ la, $5+5$ post macrosetae; urotergite VIII with $6+6$ post macrosetae; abdominal segment IX with $8+7$ post macrosetae. Urosternite I with $7+7$, urosternites II-VII with $5+5$, urosternite VIII with $2+2$ macrosetae, mostly short with long barbs. Subequal claws (1.1) with small backward overhang. Male with glandular $g_{l}$ setae and enlarged appendages with thick glandular $a_{l}$ setae; female with enlarged subcylindrical appendages with glandular $a_{l}$ setae. Stylar setae with a few barbs.

\section{Habitat and distribution}

Hypogean species found in three caves (Baba pećina, Crnulja ponor and Žira jama) in Bosnia and Herzegovina for the type form and one cave for the aff. form (Vidovića špilja, Croatia); all localities in the Dinaric Mountains.

\section{Plusiocampa (Plusiocampa) lindbergi Condé, 1956}

Fig 119

Plusiocampa lindbergi Condé, 1956a: 7, figs 1-2.

\section{Diagnosis (Condé 1956a)}

Slightly troglomorphic species. Antennae with 34-37 antennomeres; five olfactory chemoreceptors in cupuliform organ of a possibly regenerated antenna; non-protruding frontal process with nontubercular setae. Pronotum with $1+1 m a, 4+4 l a, 2+2 l p$ macrosetae; mesonotum with $1+1 m a, 2+2 l a$, $2+2$ lp macrosetae; metanotum with 1+1 ma, 2+2 lp macrosetae; long, large, barbed notal macrosetae; smooth clothing setae. Two ventral tibial macrosetae; subequal claws (1.05-1.1) with middle-sized lateral crests, posterior claw with no backward overhang. Urotergites I-III with 1+1 post macrosetae; urotergite IV with $1+1$ la, $2+2$ post macrosetae; urotergites V-VII with $1+1$ la, 4+4 post macrosetae; urotergite VIII with $6+6$ post macrosetae; abdominal segment IX with $8+8$ post macrosetae; urosternite I with 7+7, urosternites II-VII with 5+5, urosternite VIII with $2+2$ macrosetae. Male with glandular $g_{l}$ setae, enlarged subcylindrical appendages with glandular $a_{l}$ setae; female with slender, subcylindrical appendages. 


\section{Remarks}

The study of one male adult of $4.6 \mathrm{~mm}$ body length collected from the MSS habitat in Xànthi, Gérakas, Greece (see Table S2 in Supplementary Material) allows the addition of information on the urosternites of the male. It has a narrow area of 96 glandular $g_{1}$ setae, arranged in 2-3 rows; enlarged and subcylindrical appendages with a distal area of up to 60 glandular $a_{1}$ setae (Fig. 119).

\section{Habitat and distribution}

Subterranean species known from Saint-Jean-le-Prodrome Cave (Spilaio Pelade) and from the MSS habitat near Xánthi, both on the Balkan Peninsula, in the Macedonian and Greek regions.

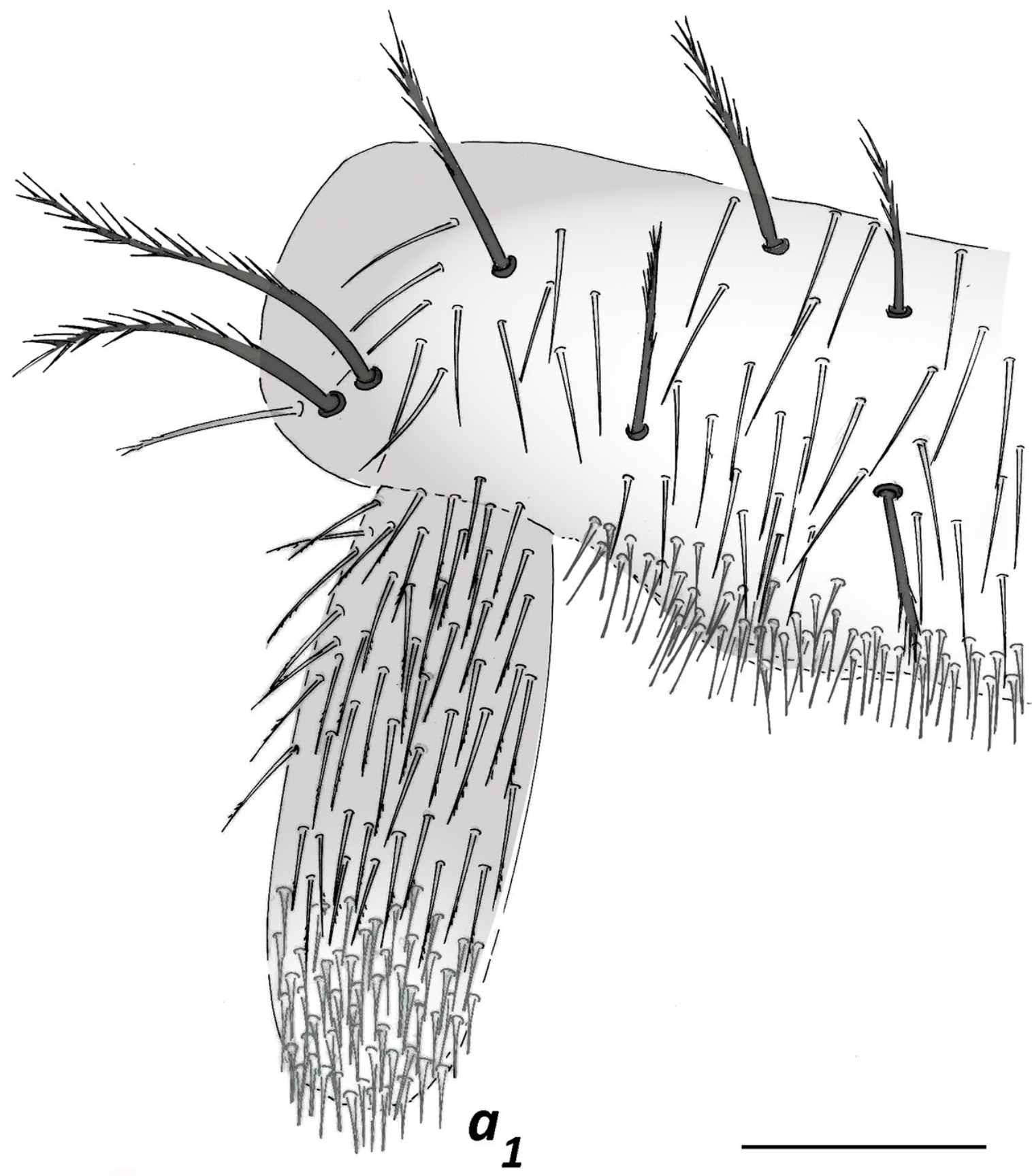

Fig. 119. Plusiocampa (Plusiocampa) lindbergi Condé, 1956, đ̃, $4.6 \mathrm{~mm}$ long, from MSS in Gérakas, Greece (Coll. AS). First urosternite, right side, glandular $g_{1}$ and $a_{1}$ setae. Scale bar: $0.1 \mathrm{~mm}$. 
Plusiocampa (Plusiocampa) lucenti Sendra \& Condé, 1986

Plusiocampa lucenti Sendra \& Condé, 1986: 971, figs 1-3, table 1.

Diagnosis (Sendra \& Condé 1986; Sendra et al. 2004)

Troglomorphic species. Antennae with 37-40 antennomeres; 17-21 complex olfactory chemoreceptors in cupuliform organ; non-protruding frontal process with non-tubercular setae. Pronotum with $1+1$ $m a, 2+2-3+3 l a, 2+2$ lp macrosetae; mesonotum with $1+1 m a, 2+2-3+3 l a, 2+2 l p, 1+1(0+1) m i$, $1+1(0+1)$ li macrosetae; metanotum with $1+1 \mathrm{ma}, 1+1 \mathrm{la}, 2+2 \mathrm{lp}, 1+1 \mathrm{mi}, 1+1-0+0$ li macrosetae; long, barbed notal macrosetae; sparse notal clothing setae. Two or three ventral tibial macrosetae; unequal claws (1.30) with large lateral crests, posterior claw with backward overhang. Urotergites I-II with $1+1$ post macrosetae; urotergite III with $1+1$ la, $1+1$ post macrosetae; urotergite IV with $1+1$ la, $2+2$ post macrosetae; urotergites V-VII with $1+1$ la, $4+4$ post macrosetae; urotergite VIII with $6+6$ post macrosetae; abdominal segment IX with $8+8$ post macrosetae. Urosternite I with $7+7(7+1+7)$, urosternites II-VII with 5+5-6+6, urosternite VIII with $2+2$ macrosetae. Male without glandular $g_{1}$ setae, slightly subcylindrical appendages with glandular $a_{1}$ setae; female appendages like male appendages. Spermatozoid fascicle wheels with 2 turns of $140-160 \mu \mathrm{m}$ long and $1.5 \mu \mathrm{m}$ wide filament.

\section{Habitat and distribution}

Subterranean species inhabiting seven caves around the north-eastern Pre-Baetic reliefs on the Iberian Peninsula. Furthermore, it slightly extends its distribution to three more caves in the south of the Iberian Mountain Range.

Plusiocampa (Plusiocampa) magdalenae Condé, 1957

Plusiocampa magdalenae Condé, 1957: 9, fig. 1.

Diagnosis (Condé 1957, 1961, 1983; Bareth 2006)

Troglomorphic species. Antennae with 31-33 antennomeres; ten olfactory chemoreceptors in cupuliform organ; non-protruding frontal process with non-tubercular setae. Pronotum with $1+1 m a, 2+2-3+3 l a$, $2+2$ lp macrosetae; mesonotum with $1+1 m a, 3+3(2+2) l a, 2+2 l p, 0+1 m p(1+0 \mathrm{smp})$ macrosetae; metanotum with $1+1 m a, 1+1 l a, 2+2 l p, 1+1 s m p$ macrosetae; long, barbed notal macrosetae; sparse notal clothing setae. Three or four ventral tibial macrosetae; slightly unequal claws with large lateral crests, posterior claw with a small backward overhang. Urotergite I with $1+1$ post macrosetae; urotergite II with 1+1-2+2 post macrosetae; urotergite III with 2+2-3+4 post macrosetae; urotergite IV with $2+2$ la, $5+5$ post macrosetae; urotergite $\mathrm{V}$ with $3+3$ la, 5+5-5+4 post macrosetae; urotergite $\mathrm{VI}$ with $3+3$ la, $5+5$ post macrosetae; urotergite VII with $3+3$ la, 4+5-5+5 post macrosetae; urotergite VIII with $6+6$ post macrosetae; abdominal segment IX with $8+8$ post macrosetae; thick clothing setae on abdominal segments IX-X; urosternite I with $7+7$, urosternites II-VII with $5+5$, urosternite VIII with $2+2$ macrosetae. Male unknown; female appendages slightly enlarged, from subcylindrical to conical in shape, with glandular $a_{1}$ setae.

\section{Habitat and distribution}

Subterranean species found in two adjacent caves, Grotte du Pertuis and Trou Miette, north of Méailles, Alpes de Haute-Provence, southeastern France.

Plusiocampa (Plusiocampa) notabilis Silvestri, 1912

Plusiocampa notabilis Silvestri, 1912: 143, fig. xxix. 
Diagnosis (Silvestri 1912; Condé 1978; Bareth 2006)

Non-troglomorphic species. Antennae with 25-27 antennomeres. Pronotum with $1+1 \mathrm{ma}, 4+4 \mathrm{la}$, $2+2$ lp macrosetae; mesonotum with $1+1 \mathrm{ma}, 3+3 \mathrm{la}, 2+2 \mathrm{lp}, 1+1 \mathrm{mp}$ macrosetae; metanotum with 1+1 $m a, 1+1 l a, 2+2 l p, 1+1 \mathrm{mp}$ macrosetae; long, thin barbed macrosetae; sparse smooth, long notal clothing setae. Two ventral tibial macrosetae; small subequal claws with small lateral crests, posterior claw with no backward overhang. Urotergites I-II with $1+1$ post macrosetrae; urotergite III with $2+2$ post macrosetae; urotergites IV-VII with $1+1$ la, 5+5 post macrosetae; urotergite VIII with $6+6$ post macrosetae; abdominal segment IX with $8+8$ post macrosetae; urosternite I with $7+7$, urosternites II-VII with $5+5$, urosternite VIII with $2+2$ macrosetae. Male with glandular $g_{1}$ setae, subcylindrical appendages with glandular $a_{1}$ setae; female appendages like male appendages.

\section{Habitat and distribution}

Soil-dwelling species found at six edaphic sites on the island of Corsica, one on Isola Zannone and two at inland localities in Calabria and Lazio, Italian Peninsula.

\section{Plusiocampa (Plusiocampa) pouadensis pouadensis (Denis, 1930)}

Figs 120-123

Troglocampa pouadensis Denis, 1930: 37, figs 28-35.

Diagnosis (Denis 1930; Condé 1948b; Bareth 2006)

Troglomorphic species. Antennae with 33-35 antennomeres, protruding frontal process with tubercular setae. Pronotum with $1+1 m a, 3+3$ la, $2+2$ lp macrosetae; mesonotum with $1+1 m a, 3+3 l a, 3+3 l p$ macrosetae; metanotum with $1+1 \mathrm{ma}, 2+2 \mathrm{la}, 3+3 \mathrm{lp}$ macrosetae; long, barbed notal macrosetae; barbed notal clothing setae. Two ventral tibial macrosetae; unequal claws with large lateral crests, posterior claw with a backward overhang. Urotergites I-III with $1+1$ post macrosetae; urotergite IV with $1+1$ la, $5+5$ post macrosetae; urotergites V-VI with $1+1-2+2$ la, $5+5$ post macrosetae; urotergite VII with $2+2$ la, $5+5$ post macrosetae; urotergite VIII with $6+6$ post macrosetae; abdominal segment IX with $8+8$ post macrosetae. Urosternite I with $8+8$, urosternites II-VII with $6+6$, urosternite VIII with $2+2$ macrosetae. Male with a area of glandular $g_{1}$ setae, developed large appendages with a large area of glandular $a_{2}$ setae and an apical area of glandular $a_{l}$ setae; female with subcylindrical appendages with glandular $a_{l}$ setae.

\section{Remarks}

The studied material from Pouade Cave (see Table S2 in Supplementary Material) has allowed a better observation of the first urosternite with its very large appendages in males (Fig. 120), as well as a large area of glandular $a_{2}$ setae. The first urosternite of females has subcylindrical appendages (Figs 121, 123) and the surface is completely smooth (Fig. 122).

\section{Habitat and distribution}

Subterranean species only found in Grotte de Pouade, Banyuls de la Marenda, on the French side of the Eastern Pyrenees.

Plusiocampa (Plusiocampa) pouadensis fouresi Condé, 1955

Plusiocampa pouadensis fouresi Condé, 1955a: 27.

Differential diagnosis against the type form (Condé 1955a; Bareth \& Condé 1996)

Urotergite III with 2+2 post macrosetae; urotergites V-VII with 2+2 la, 6+6 post macrosetae; urotergite VIII with $7+7$ post macrosetae. 


\section{Habitat and distribution}

Subterranean subspecies inhabiting two caves on the French side of the Eastern Pyrenees.
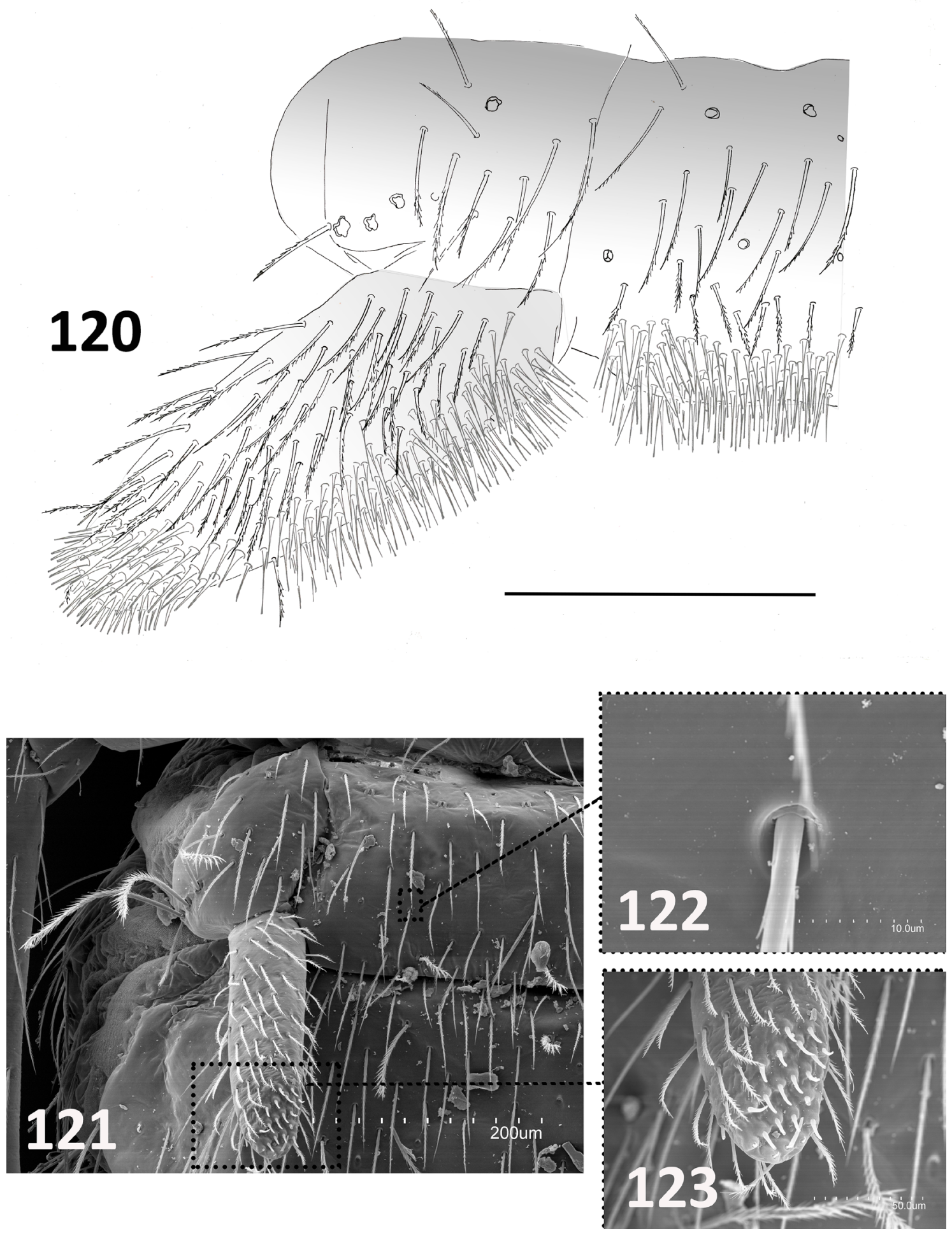

Figs 120-123. Plusiocampa (Plusiocampa) pouadensis pouadensis (Denis, 1930), from Grotte Pouade, Banyuls-sur-Mer, France (Coll. AS). 120. $\delta^{\lambda}$, urosternite I, right side, with glandular $g_{1}, a_{1}$ and $a_{2}$ setae. 121. + , urosternite I. 122. Surface of urosternite I, detail. 123. ㅇ, urosternite I appendage. Scale bar: $120=0.2 \mathrm{~mm}$. 
SENDRA A. et al., Euro-Mediterranean Plusiocampinae and tachycampoid diplurans

Plusiocampa (Plusiocampa) pouadensis leoni Condé, 1951

Plusiocampa pouadensis leoni Condé, 1951: 60, fig. 2.

Differential diagnosis against the type form (Condé 1951, 1955a; Bareth \& Condé 1996)

Antennae with 28-33 antennomeres. Urotergite III with $2+2$ post macrosetae; urotergite VIII with 7+7 post macrosetae.

\section{Habitat and distribution}

Subterranean subspecies inhabiting three caves on the Spanish side of the Eastern Pyrenees.

Plusiocampa (Plusiocampa) provincialis provincialis Condé, 1949

Plusiocampa provincialis Condé, 1949: 166, figs a-b, d-h.

Diagnosis (Condé 1949, 1957, 1981a, 1983; Bareth 2006)

Troglomorphic species. Antennae with 30-36 antennomeres; sensillum of third antennomere very long, in ventral position; protruding frontal process with tubercular setae. Pronotum with $1+1 \mathrm{ma}, 4+4 \mathrm{la}$, $2+2$ lp macrosetae; mesonotum with $1+1 \mathrm{ma}, 3+3 \mathrm{la}, 2+2 \mathrm{lp}, 1+1 \mathrm{mp}$ macrosetae; metanotum with $1+1 \mathrm{ma}, 2+2 \mathrm{la}, 2+2 \mathrm{lp}, 1+1 \mathrm{mp}$ macrosetae; long, barbed notal macrosetae; barbed notal clothing setae. Two ventral tibial macrosetae; subequal claws (1.06) with large lateral crests, posterior claw with a small backward overhang. Urotergites I-II with $2+2$ post macrosetae; urotergite III with $2+2-$ $3+3$ post macrosetae; urotergite IV with $1+1$ la, $5+5$ post macrosetae; urotergite $\mathrm{V}$ with $2+2$ la, $5+5$ post macrosetae; urotergites VI-VII with $3+3$ la, $5+5$ post macrosetae; urotergite VIII with $7+7$ post macrosetae; thick clothing setae on abdominal segments IX-X; urosternite I with 7+7, urosternites IIVII with 5+5, urosternite VIII with $2+2$ macrosetae. Male with a large area of glandular $g_{l}$ setae and appendages with glandular $a_{2}$ setae.

\section{Habitat and distribution}

Subterranean species found in nine caves around Massif de Marseilleveyre and the Sainte-Baume Massif, Alps de Provence, southeastern France.

Plusiocampa (Plusiocampa) provincialis praedita Condé, 1949

Plusiocampa provincialis praedita Condé, 1949: 169, fig. c.

Differential diagnosis against the type form (Condé 1949, 1983; Bareth 2006)

Protruding frontal process with slightly tubercular setae. Two ventral tibial macrosetae. Thick clothing setae on abdominal segments VIII-X. Male with slightly enlarged appendages with glandular $a_{l}$ setae; female appendages like male appendages.

\section{Habitat and distribution}

Subterranean subspecies found in Grotte du Saint-Trou in the Saint-Baume Massif, northeast of Évenos, Alps de Provence, southeastern France. 
Table 9. Plusiocampa (Plusiocampa) rhea Sendra sp. nov. Length of the body, antennae and metathoracic legs (measurements in $\mathrm{mm}$ ), in addition to the number of antennomeres.

\begin{tabular}{|c|c|c|c|c|}
\hline Specimen (Coll. AS) & Body length & No. of antennomeres & Antennal length & Metathoracic leg length \\
\hline$\hat{\partial}$, holotype & 4.9 & 32 & 4.0 & 2.2 \\
\hline$\partial^{\lambda}$, paratype & 4.0 & 30 & 3.6 & - \\
\hline$\lesssim$, paratype & 3.8 & 33 & 3.8 & 1.9 \\
\hline
\end{tabular}

Plusiocampa (Plusiocampa) rhea Sendra sp. nov. urn:1sid:zoobank.org:act:79F00B32-CCCA-4195-BB1F-52D3B2225C20

Fig. 124; Table 9

\section{Etymology}

This species is named in honour of Rhea, mother of the Greek god Zeus and daughter of Gaea, the Earth goddess. She gave birth and cared for her son Zeus in the Ideon Andron Cave located in Mount Psiloritis, the highest mountain in Crete, where this new species was found.

\section{Material examined}

\section{Holotype}

GREECE $\bullet 1$; ; Crete, Anogeia, Ideon Antron Cave (Zeus Cave) at twilight zone area, near entrance; 1174 m a.s.1.; 22 Mar. 2006; Alberto Sendra leg.; MZB 2019-1033.

\section{Paratypes}

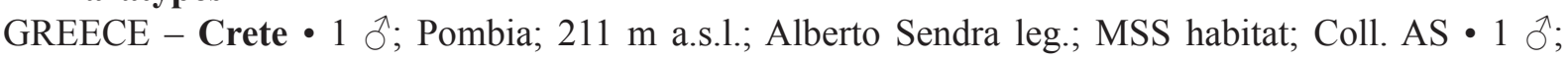
Sissarha; $601 \mathrm{~m}$ a.s.1.; MSS habitat; Alberto Sendra leg.; Coll. AS.

\section{Description}

BoDy. Body length 3.8-4.9 mm. Epicuticle smooth under optical microscope; body with thin, middlesized clothing, covered or not by a few thin barbs.

HEAD. Three intact antennae in holotype and paratypes, with 30, 32 and 33 antennomeres, slightly shorter than body length (Table 9). Small coniform sensillum of third antennomere located in ventral position between $c$ and $d$ macrosetae. Central antennomeres $1.5 \times$ as long as wide, apical antennomere $1.6 \times$ as long as wide. Cupuliform organ occupying $1 / 5$ of total length of apical antennomere, with 8-9 complex olfactory chemoreceptors. Gouge sensilla $30-32 \mu \mathrm{m}$ long in a single distal whorl of 12-16 sensilla on each medial and distal antennomere. Frontal process plain, with non-tubercular setae and macrosetae with barbs along half to two-thirds; macrosetae along line of insertion of antennomere and $x$ setae with similar lengths $(a / i / p / x$ with relative lengths of $36 / 42 / 35 / 52$ in holotype). Suboval labial palps with latero-external sensillum larger than sensillum of third antennomere, with two guard setae, up to 12 setae on anterior border and up to 180 neuroglandular setae.

THORAX. Distribution of thoracic macrosetae (Fig. 124): pronotum with $1+1 m a, 2+2 l a_{3,4}$ and $2+2 s l a_{1,2}$, $2+2 l p_{l, 3}$ (with additional $1+1$ extra sma near the sagittal plane); mesonotum with $1+1 \mathrm{ma}, 3+3 l a_{1,2,3}$, $3+3 l p_{1,2,3}, 1+1 \mathrm{mp}$; metanotum with $1+1 \mathrm{ma}, 3+3 l p_{1,2,3}, 1+1 \mathrm{mp}$. All notal macrosetae long, robust, covered by thin barbs along distal third or half; submacrosetae sla $a_{1,2}$ and sma thinner and shorter than notal macrosetae, but with same large base; marginal setae longer than clothing setae, covered by thin barbs along distal three-fourths. Legs elongated, pretarsus of metathoracic legs slightly overpassing end of abdomen (Table 9). Femur I without dorsal macrosetae but with one long, barbed ventral macroseta; femora II-III with one long, barbed dorsal and one long, barbed ventral macroseta. Tibia I with one 
short, barbed ventral macroseta; tibiae II-III with two short, barbed ventral macrosetae. Calcars with 2-3 rows of long barbs from base to tip, smooth on one narrow side along calcar. Dorsal and lateral subapical tarsal setae smooth. Slightly unequal claws (posterior claw 1.15-1.2× as long as anterior one); posterior claw without backward overhang; lateral crests well developed. Pretarsal processes long, setiform, reaching extremities of claws.

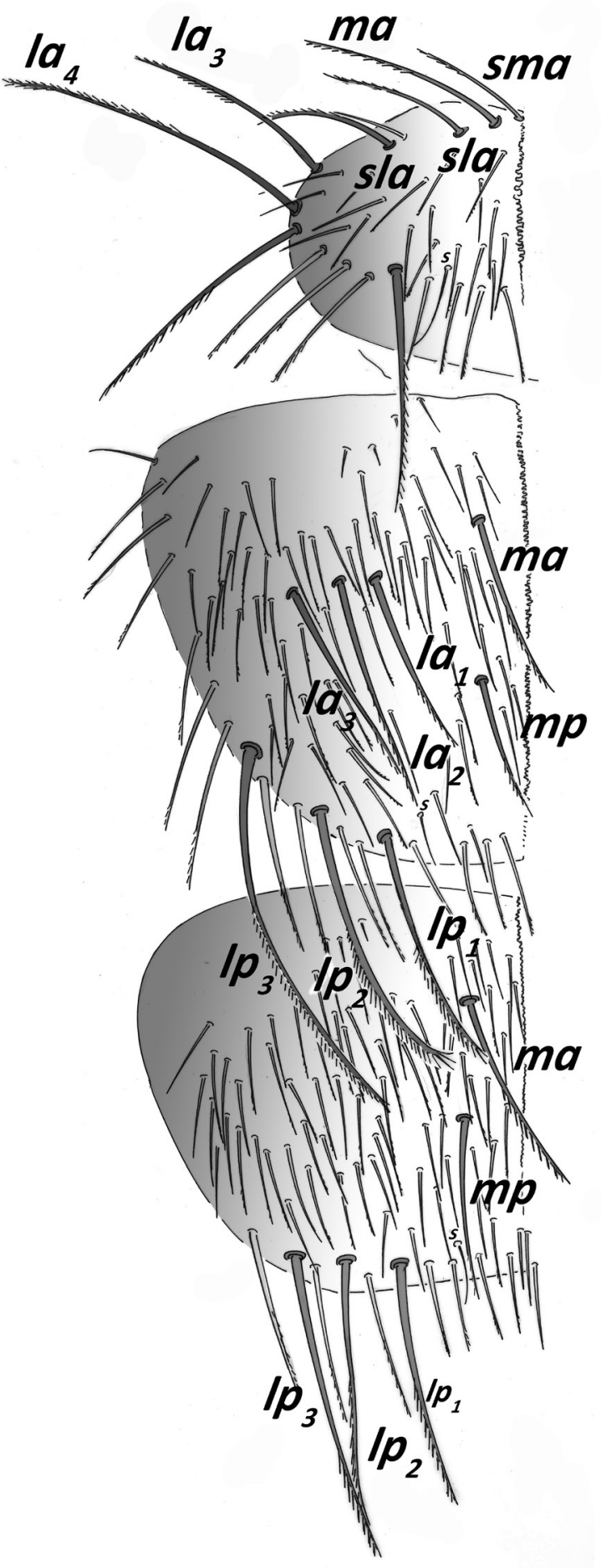

Fig. 124. Plusiocampa (Plusiocampa) rhea Sendra sp. nov., holotype, $\sigma^{\top}, 4.9 \mathrm{~mm}$ long, from Ideon Antron Cave entrance, Anogeia, Crete (MZB 2019-1033). Pronotum, mesonotum and metanotum, left side $(\mathrm{s}=$ setiform sensillum). Scale bar: $0.3 \mathrm{~mm}$. 
AвDOMEN. Distribution of abdominal macrosetae on tergites: $1+1$ post $t_{1}$ on I-III $(0+1$ la on III); $1+1$ la, $2+2$ post $_{1,2}$ on IV; $1+1$ la, $5+5$ post $_{1-5}$ on V-VII; $7+7$ post on VIII; $9+9$ post on abdominal segment IX. All post urotergal macrosetae thick, long and covered by thin barbs along distal four-fifths; la urotergal macrosetae shorter than post macrosetae, covered by barbs along distal half. Urosternite I with 9+9, urosternites II-VII with 5+5; urosternite VIII with $2+2$ macrosetae; all urosternal macrosetae robust and large, covered by long barbs along distal three-fourths to four-fifths. Apical, subapical and ventromedial setae with abundant long barbs.

CERCI. One incomplete cercus on $4 \mathrm{~mm}$ long paratype with six articles in addition to basal article, $3.8 \mathrm{~mm}$ long; their articles show whorls of long macrosetae covered by thin barbs along distal twothirds, combined with whorls of smooth, thin setae, shorter than macrosetae, in addition to one apical whorl of short setae with a few distal barbs.

Genital oRgans. Male urosternite I with up to 160 glandular $g_{I}$ setae arranged in up to five rows with slightly enlarged subcylindrical appendages, each bearing up to 19 glandular $a_{l}$ setae.

\section{Phyletic affinities, habitat and distribution}

Plusiocampa (P.) rhea sp. nov. has $3+3$ lateral posterior macrosetae on the mesonotum and metanotum, a feature only found in $P$. (P.) pouadensis (Condé 1948c; Sendra \& Escolà 2004). Nevertheless, $P$. (P.) rhea sp. nov. has medial posterior mesonotal and metanotal macrosetae, which are absent in $P$. (P.) pouadensis. Furthermore, $P$. $(P$.$) pouadensis is a troglomorphic species from the Eastern Pyrenees,$ whereas $P$. ( $P$.) rhea sp. nov. has been found in hypogean habitats, in soil, MSS and the twilight zones of caves at three locations on Crete.

\section{Plusiocampa (Plusiocampa) romana Condé, 1954}

Plusiocampa romana Condé, 1954b: 37, figs a-e.

Diagnosis (Condé 1954b, 1983; Ramellini 1990)

Troglomorphic species. Antennae with 26 antennomeres; 12 complex olfactory chemoreceptors in cupuliform organ; frontal process with non-tubercular setae. Pronotum with $1+1 m a, 3+3 l a, 2+2 l p$ macrosetae; mesonotum with $1+1 \mathrm{ma}, 3+3 \mathrm{la}, 2+2 \mathrm{lp}, 1+1 \mathrm{mp}$ macrosetae; metanotum with $1+1 \mathrm{ma}$, $2+2 l a, 2+2 l p, 1+1 \mathrm{mp}$ macrosetae; thin, barbed notal macrosetae; sparse notal clothing setae. Two to four ventral tibial macrosetae; slightly unequal claws with large lateral crests, posterior claw with a backward overhang. Urotergite I with $1+1$ post macrosetae; urotergite II with $2+2$ post macrosetae; urotergite III with $4+4$ post macrosetae; urotergite IV with $2+2$ la, $5+5$ post macrosetae; urotergite $\mathrm{V}$ with $2+2-3+3$ la, $5+5$ post macrosetae; urotergites VI-VII with $3+3$ la, $5+5$ post macrosetae; urotergite VIII with $6+6$ post macrosetae; urosternite I with $7+7$, urosternites II-VII with $5+5$, urostenite VIII with $2+2$ macrosetae. Male unknown.

\section{Habitat and distribution}

Subterranean species found on the Italian Peninsula in two caves, Grotta di Santa Liberata (Toscana) and Grotta dell'Inferniglio (Latium), and in soil habitat on Monti Ausoni, central Apennine Mountains.

Plusiocampa (Plusiocampa) rudnica Blesić, 1992

Plusiocampa rudnica Blesić, 1992: 145, figs 1-4.

Diagnosis (Blesić 1992)

Non-troglomorphic spceies. Antennae with 27-28 antennomeres. Pronotum with $1+1 \mathrm{ma}, 2+2 \mathrm{la}, 2+2 \mathrm{lp}$ macrosetae; mesonotum with $1+1 \mathrm{ma}, 2+2 \mathrm{la}, 2+2 \mathrm{lp}, 1+1 \mathrm{mp}$ macrosetae; metanotum with $1+1 \mathrm{ma}, 2+2$ 
SENDRA A. et al., Euro-Mediterranean Plusiocampinae and tachycampoid diplurans

$l p, 1+1 m p$ macrosetae. Two or three ventral tibial macrosetae. Subequal claws with large lateral crests, posterior claw with a small backward overhang. Urotergites I-III with $1+1$ post macrosetae; urotergites IV-VII with $1+1$ la, $4+4$ post macrosetae; urotergite VIII with $6+6$ post macrosetae; abdominal segment IX with $8+8$ post macrosetae; urosternite I with $7+7$, urosternites II-VII with $5+5$, urosternite VIII with $2+2$ macrosetae. This species should be judged with caution due to the fact that it is poorly described.

\section{Habitat and distribution}

Soil-dwelling species distributed in Rudnik Mountain (Serbia) on the west of the Balkan Peninsula.

Plusiocampa (Plusiocampa) rybaki Condé, 1956

Plusiocampa rybaki Condé, 1956a: 11.

\section{Diagnosis}

Plusiocampa (P.) rybaki was poorly described by Condé, based on specimens from three caves, one in Attica, Greece (Cave I in Rachi, northern part of Mt Ymittos) and two on Crete (Achyrospilo Cave on the Acrotiri Peninsula, Chania and Sarchos Cave, Irakleio). Troglomorphic species. Antennae with 40-44 antennomeres, large cupuliform organ with 13-21 olfactory chemoreceptors; frontal process with tubercular setae. Mesonotum with $3+3 \mathrm{la}$ macrosetae, and mesonotum and metanotum with $m p$ macrosetae. Pretarsus with large lateral crests. Urotergites V-VII with $5+5$ post macrosetae.

\section{Remarks}

The specimens from Crete reported by Condé (1956a) as $P$. (P.) rybaki, as well as two specimens collected by P. Strinati on Crete (deposited in the Natural History Museum of Geneva on two slides labelled by B. Condé as Plusiocampa rybaki: 1 male from Melidoni Spilia, 2 Aug. 1983 and 1 female from Grotta "Sentoni"), are here considered to belong to $P$. ( $P$.) hoffmanni sp. nov.

Plusiocampa (Plusiocampa) sardiniana Condé, 1981

Plusiocampa sardiniana Condé, 1981b: 593, fig. 1 b.

Plusiocampa provincialis? - Condé 1953: 36.

Diagnosis (Condé 1953b, 1981b, 1983)

Troglomorphic species. Antennae with 33-38 antennomeres; protruding frontal process with tubercular setae. Pronotum with $1+1 \mathrm{ma}, 4+4 l a, 2+2 l p$ macrosetae; mesonotum with $1+1 \mathrm{ma}, 3+3$ $l a, 2+2 l p, 1+1 \mathrm{mp}$ macrosetae; metanotum with $1+1 \mathrm{ma}, 2+2 \mathrm{la}, 2+2 \mathrm{lp}, 1+1 \mathrm{mp}$ macrosetae. Two ventral tibial macrosetae; slightly unequal claws (1.15) with large lateral crests, posterior claw with a backward overhang. Urotergites I-III with $2+2$ post macrosetae; urotergite IV with $1+1(0+1) l a$, $5+5$ post macrosetae; urotergite $\mathrm{V}$ with $1+1(1+2)$ la, $5+5$ post macrosetae; urotergite VI with $2+2$ $(1+2) l a, 5+5$ post macrosetae; urotergite VII with $2+2-3+3$ la, $5+5$ post macrosetae; urotergite VIII with $6+6$ post macrosetae; abdominal segment IX with $8+8$ post macrosetae; thick clothing setae on abdominal segments IX-X; urosternite I with $7+7$, urosternites II-VII with $5+5$, urosternite VIII with $2+2$ macrosetae. Male without glandular $g_{1}$ setae or glandular $a_{2}$ setae, with the exception of $1+1 g_{1}$ and 2-3 $a_{2}$ in one specimen; female with subcylindrical appendages with glandular $a_{1}$ setae.

\section{Habitat and distribution}

Subterranean species found only in the San Giovanni Caves, Sardinia. 
Plusiocampa (Plusiocampa) schweitzeri Condé, 1947

Figs 125-134

Plusiocampa schweitzeri Condé, 1947a: 23, fig. 3.

Diagnosis (Condé 1947a)

Troglomorphic species. Antennae with 22-29 antennomeres; cupuliform organ with seven or eight complex olfactory chemoreceptors. Protruding frontal process with tubercular setae. Pronotum with 1+1
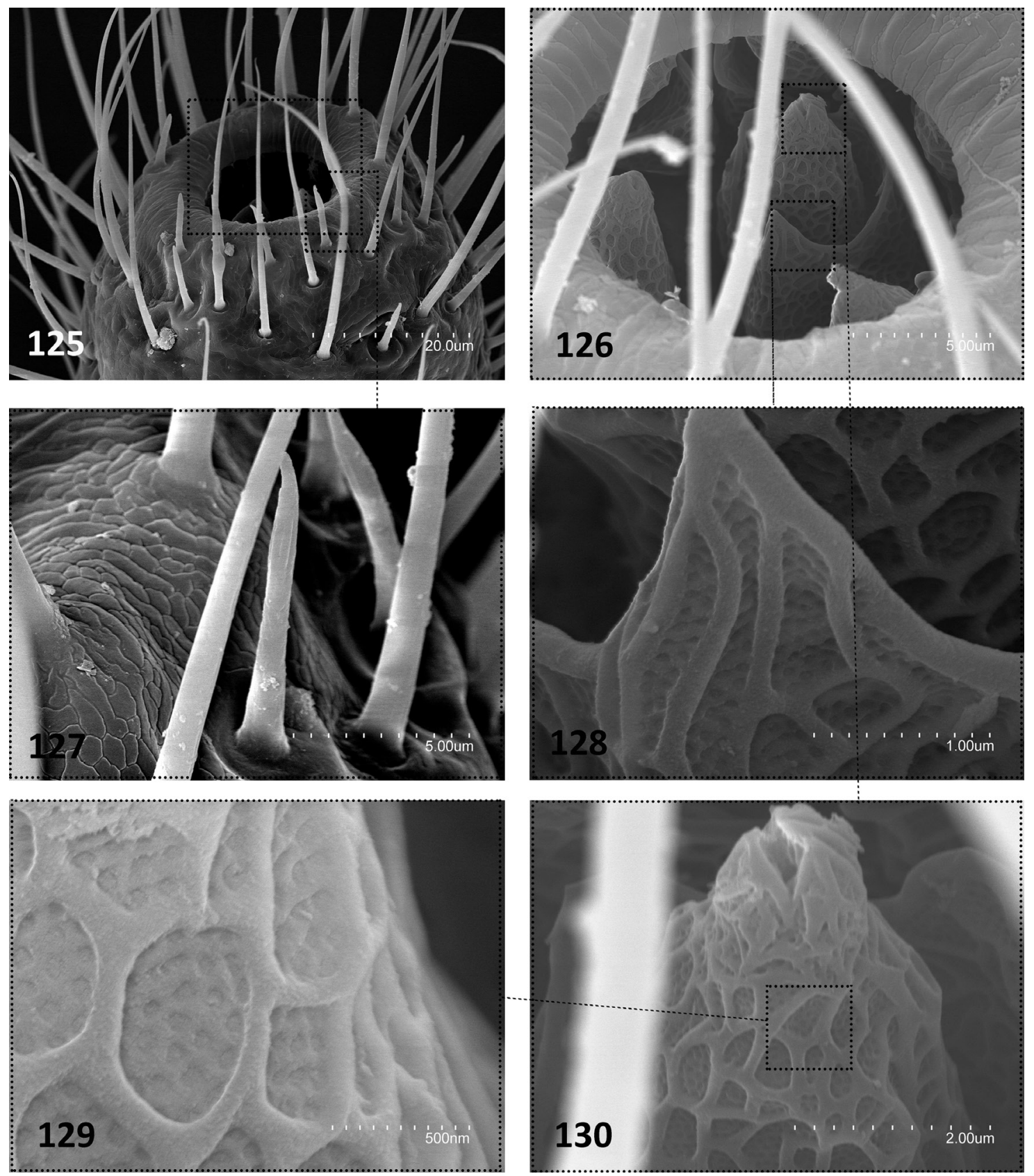

Figs 125-130. Plusiocampa (Plusiocampa) schweitzeri Condé, 1947, from Govještica, Banja stijena, Rogatica, Bosnia and Herzegovina (Coll. AS). 125. Tip of last antennomere. 126. Cupuliform organ. 127. Detail of rim of cupuliform organ with a coniform sensillum. 128. Olfactory chemoreceptor, detail. 129. Apical portion of an olfactory chemoreceptor. 130. Surface of olfactory chemoreceptor, detail. 
$m a, 2+2 l a, 2+2$ lp macrosetae; mesonotum with $1+1 m a, 2+2-2+3 l a, 2+2 l p$ macrosetae; metanotum with 1+1 $m a, 1+1$ la, 2+2 lp macrosetae; long, barbed notal setae; abundant barbed notal clothing setae. Two ventral tibial macrosetae; unequal claws (1.3-1.5) with large lateral crests, posterior claw with a backward overhang. Urotergites I-III with $1+1$ post macrosetae; urotergite IV with $1+1$ la, 2+2-3+3 post macrosetae; urotergite $\mathrm{V}$ with $1+1$ la, $4+4-5+5$ post macrosetae; urotergites VI-VII with $1+1-2+2$ la, $5+5(4+5)$ post macrosetae; urotergite VIII with $6+6$ macrosetae; abdominal segment IX with $8+8-8+9$ macrosetae; urosternite I with $7+7$, urosternites II-VII with $5+5$, urosternite VIII with $2+2$ macrosetae. Male with an area of glandular $g_{1}$ setae, subcylindrical and slightly enlarged appendages with glandular $a_{1}$ setae; female appendages like male appendages.

\section{Remarks}

The 17 specimens studied, from four caves in the Dinaric Mountains (Bosnia and Herzegovina) (see Table S2 in Supplementary Material), allowed us to clarify some characters: five complete antennae preserved show 28-29 antennomeres, elongated antennomeres with a distal whorl of 12-14 long gouge sensilla (30-32 $\mu \mathrm{m}$ ) (Figs 131-132); cupuliform organ with seven or eight spheroidal olfactory chemoreceptors, each with a jagged fold surrounding a central coniform structure covered by a highly visible, multiperforated polygonal net surface (Figs 125-130). Protruding frontal process with tubercular setae. Surface of epicuticle reticulate (Fig. 133). Smooth tarsal subapical setae and calcars with long barbs from base, pretarsus claws with large lateral crests (Fig. 134). Furthermore, they show a wider range in the number of urotergal macrosetae than mentioned in the diagnosis above.
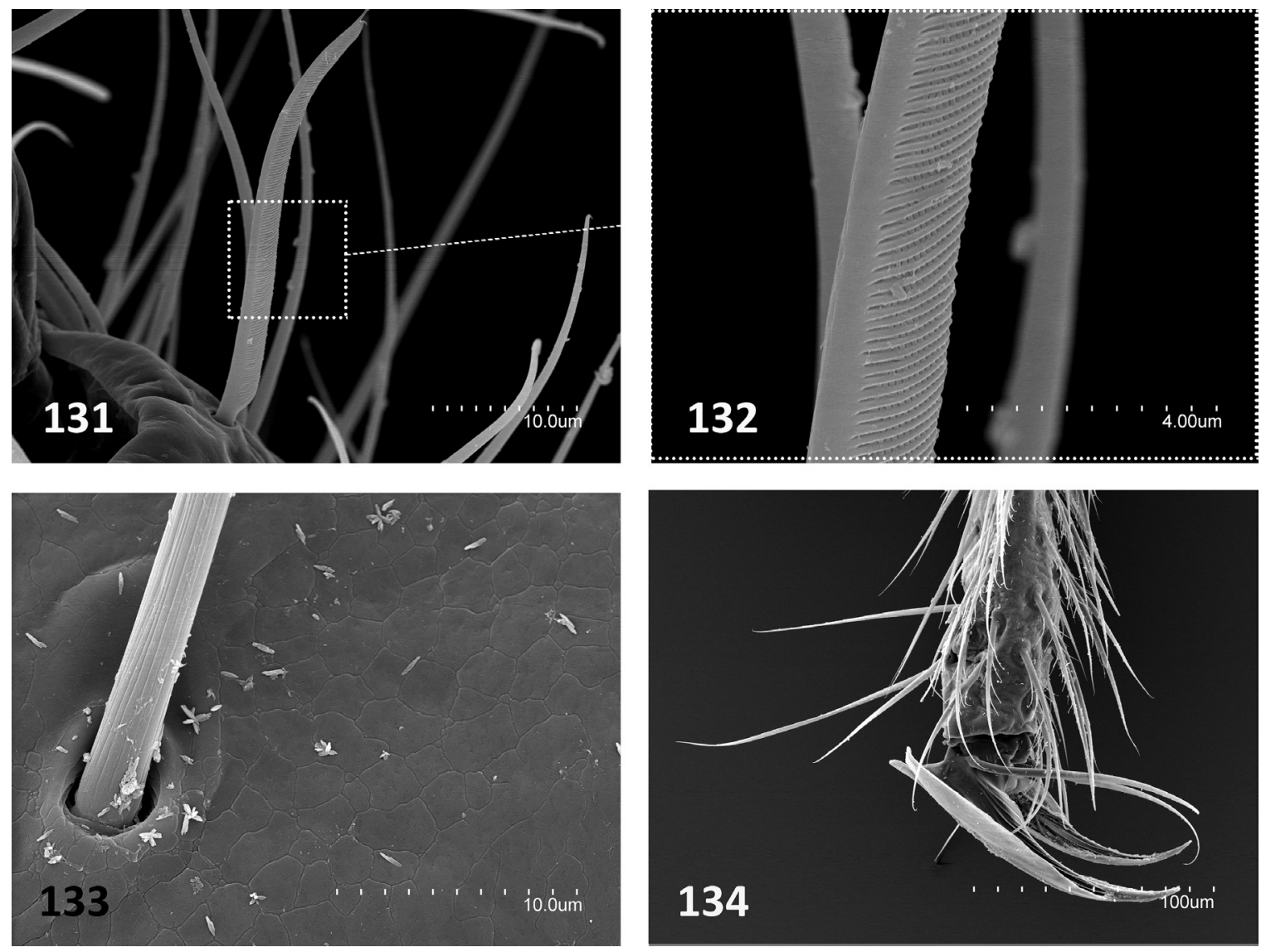

Figs 131-134. Plusiocampa (Plusiocampa) schweitzeri Condé, 1947, from Govještica, Banja stijena, Rogatica, Bosnia and Herzegovina (Coll. AS). 131. Medial antennomere, latero-distal view. 132. Medial portion of a gouge sensillum, detail. 133. Surface of metanotum, detail. 134. Distal portion of tarsus and pretarsus, lateral view. 
Plusiocampa (Plusiocampa) aff. schweitzeri Condé, 1947

\section{Differential diagnosis against the type form}

The five studied specimens from Karakaya Cave in Turkey (see Table S2 in Supplementary Material) share the same macrosetal distribution found in the specimens from Bosnia and Herzegovina, with the exception of 7+7 post macrosetae on urotergite VIII and 9+9 post macrosetae on abdominal segment IX. Furthermore, two other important features separate these two forms, i.e., the shape of the claws (subequal claws and posterior claw with no backward overhang in the form from Karakaya Cave) and features of the frontal process (simple frontal process without tubercular setae in specimens from Karakaya Cave). However, more material is needed to describe these specimens with different features from Karakaya Cave, Mihalliçik as a new species.

\section{Habitat and distribution}

Subterranean species found in five caves of Bosnia and Herzegovina in the Dinaric Mountains. The aff. form was found in a cave in the northeast of the Anatolian Peninsula.

Plusiocampa (Plusiocampa) socia Condé, 1983

Plusiocampa socia Condé, 1956b: 200 (nomen nudum).

Plusiocampa socia Condé, 1983: 900, figs 1a, 2-4.

\section{Diagnosis (Condé 1983)}

Troglomorphic species. Antennae with 36 antennomeres; nine complex olfactory chemoreceptors in cupuliform organ; protruding frontal process with non-tubercular setae. Pronotum with $1+1 \mathrm{ma}, 3+3$ $l a, 2+2$ lp macrosetae; mesonotum with $1+1 \mathrm{ma}, 3+3 \mathrm{la}, 2+2 \mathrm{lp}, 1+1 \mathrm{mp}$ macrosetae; metanotum with $1+1 m a, 2+2 l a, 2+2 l p, 1+1 m p$ macrosetae; long, barbed notal macrosetae; abundant notal clothing setae, smooth or with a few distal barbs. Two ventral tibial macrosetae; subequal claws (1.05) with large lateral crests, posterior claw with a small backward overhang. Urosternite I with $2+1$ post macrosetae; urotergite II with $2+2$ post macrosetae; urotergite III with $0+1$ la, $2+2$ post macrosetae; urotergites IV-V with $1+1$ la, $2+2$ post macrosetae; urotergite VI with $3+3-2+2$ la, $4+4$ post macrosetae; urotergite VII with $3+3$ la, $4+4$ post macrosetae; urotergite VIII with $6+6$ post macrosetae; urosternite I with $8+7$, urosternites II-VII with 5+5, urosternite VIII with $2+2$ macrosetae. Male unknown; subcylindrical appendages with glandular $a_{1}$ setae in females.

\section{Habitat and distribution}

Subterranean species found only in Grotta di Gana ‘e Gortoe, Siniscola, Eastern Sardinia.

\section{Plusiocampa (Plusiocmapa) solerii Silvestri, 1932}

Plusiocmpa solerii Silvestri, 1932: 72, figs viii-ix.

Diagnosis (Silvestri 1933a; Sendra et al. 2006)

Non-troglomorphic species. Antennae with 22-25 antennomeres; frontal process with non-tubercular setae. Pronotum with $1+1 m a, 4+4 l a, 2+2 l p$ macrosetae; mesonotum with $1+1 m a, 2+2 l a, 2+2 l p$ macrosetae; metanotum with $1+1 \mathrm{ma}, 1+1$ la, $2+2$ lp macrosetae; long, barbed notal macrosetae. Two ventral tibial macrosetae; slightly unequal claws (1.15) with large lateral crests, posterior claw with no backward overhang. Urotergites I-III with $1+1$ post macrosetae; urotergite IV with $1+1 l a, 2+2$ post macrosetae; urotergites V-VII with $1+1$ la, $4+4$ post macrosetae; urotergite VIII with $6+6$ post macrosetae; abdominal segment IX with $8+8$ macrosetae; urosternite I with $7+7$, urosternites II-VII with 
$5+5$, urosternite VIII with $2+2$ macrosetae. Male unknown; female with long subcylindrical appendages with glandular $a_{1}$ setae.

\section{Plusiocampa (Plusiocampa) aff. solerii Silvestri, 1932}

\section{Differential diagnosis against the type form}

The only specimen collected is a female, a troglomorphic form found in a cave on the island of Cyprus (Coll. AS). This specimen shows several taxonomical differences from the type form. Body length $5.6 \mathrm{~mm}$ (metathoracic leg $3.2 \mathrm{~mm}$ long); $8.7 \mathrm{~mm}$ long antenna with 49 antennomeres; elongated antennomeres with 16-18 long gouge sensilla, more than eight complex sensilla in cupuliform organ; 2 or 3 ventral tibial macrosetae; $1+1$ lateral anterior and $1+1$ posterior macrosetae on fourth urotergite and $2+2$ anterior lateral macrosetae on seventh urotergite.

\section{Habitat and distribution}

The type form was found in soil habitat on the island of Ródos (Greece) and at Izmir on the west coast of the Anatolian Peninsula, but the aff. troglomorphic form was found on Cyprus.

\section{Plusiocampa (Plusiocampa) spelaea Stach, 1930}

Table 10

Plusiocampa spelaea Stach, 1930: 278.

Diagnosis (Stach 1930; Condé 1954a; Paclt 1957)

Non-troglomorphic species. Antennae with 20-22 antennomeres. Pronotum with 1+1 ma, 2+2 la, $2+2$ lp macrosetae; mesonotum with $1+1 \mathrm{ma}, 3+3 \mathrm{la}, 2+2 \mathrm{lp}, 1+1 \mathrm{mp}$ macrosetae; metanotum with $1+1 \mathrm{ma}, 1+1$ $l a, 2+2 l p, 1+1 \mathrm{mp}$ macrosetae. Two ventral tibial macrosetae. Urotergites I-II with $1+1$ post macrosetae; urotergite III with $2+2$ post macrosetae; urotergites IV-VII with $1+1$ la, $5+5$ post macrosetae; urosternite I with $8+8$ ?, urosternites II-VII with $5+5$, urosternite VIII with $2+2$ macrosetae.

\section{Remarks}

The study of five females and one juvenile collected in four caves (see Table S2 in Supplementary Material) has allowed the completion of the former description, although new specimens from the type locality are needed for a proper redescription of this species. Nevertheless, a complementary and differential description has been made using the studied material.

Non-troglomorphic species (Table 10). Antennae with 21 and 23 doliiform antennomeres, apical antennomere $1.3 \times$ as long as wide, with a small cupuliform organ occupying $1 / 7$ of antennomere, with four simple olfactory chemoreceptors. Small ventral sensillum of third antennomere between $d$ and $e$ macrosetae. Non-protruding frontal process with non-tubercular setae. Labial palp suboval with a thick lateral anterior sensillum, two guard setae, up to five normal setae and 75 neuroglandular setae. Pronotum with $2+2$ la to 3+3 la macrosetae; long, barbed notal macrosetae; notal clothing setae long, smooth or with one or two distal barbs. Calcars with two rows of long barbs. Smooth subapical tarsal setae. Slightly unequal claws (1.15-1.20) with large lateral crests and a small backward overhang. Urotergite IV with $4+4$ post macrosetae (5+5 according to redescription in Paclt 1957); urotergites VIVII with 2+2 la macrosetae (1+1 la according to Paclt 1957); urotergite VIII with 6+6 post macrosetae; abdominal segment IX with $8+8$ post macrosetae; urosternite I with $7+7$, urosternites II-VII with $4+4$, urosternite VIII with 2+2 macrosetae. Stylar setae with a few long, thin bars. Female with subcylindrical appendages bearing up to 9 glandular $a_{1}$ setae. 
Table 10. Plusiocampa (Plusiocampa) spelaea Stach, 1930. Length of the body, antennae, metathoracic legs and cerci (measurements in $\mathrm{mm}$ ), in addition to the number of antennomeres and cercal articles.

\begin{tabular}{|c|c|c|c|c|c|c|}
\hline Specimen (Coll. AS) & $\begin{array}{l}\text { Body } \\
\text { length }\end{array}$ & $\begin{array}{c}\text { No. of } \\
\text { antennomeres }\end{array}$ & $\begin{array}{l}\text { Antennal } \\
\text { length }\end{array}$ & $\begin{array}{l}\text { Metathoracic } \\
\text { leg length }\end{array}$ & $\begin{array}{l}\text { No. of cercal articles } \\
\text { (base included) }\end{array}$ & $\begin{array}{c}\text { Length of } \\
\text { cercus }\end{array}$ \\
\hline juv., Domica Cave & 2.35 & 23 & 1.40 & 0.90 & 4 & 0.53 \\
\hline q, Vass Imre barlang Cave & 3.6 & 23 & 1.70 & 1.25 & 7 & 2.05 \\
\hline †, Vass Imre barlang Cave & 3.9 & 23 & 2.00 & 1.50 & 7 & 2.01 \\
\hline q, Jaskyňa nad Kadlubom Cave & 4.3 & 23 & 1.95 & 1.35 & 7 & 1.85 \\
\hline + , Jaskyňa nad Kadlubom Cave & 4.6 & - & - & 1.45 & 7 & 2.00 \\
\hline + , Drienovská jaskyňa Cave & 4.9 & 21 & 2.10 & 1.60 & - & - \\
\hline
\end{tabular}

\section{Habitat and distribution}

Apparently, this species only lives in caves, but its non-troglomorphic shape reveals a more superficial habitat (MSS or soils). It has been found in six caves in the southern karst areas of the Western Carpathians, where it was described from the Domica-Baradla cave system in the Slovak and Aggtelek Karst, on the border between Slovakia and Hungary.

Plusiocampa (Plusiocampa) strouhali strouhali Silvestri, 1933

Plusiocampa strouhali Silvestri, 1933c: 30, tables i-ii.

Diagnosis (Silvestri 1933c; Condé 1954a)

Troglomorphic species. Antennae with 40-41 antennomeres. Pronotum with $1+1 \mathrm{ma}, 2+2 \mathrm{la}, 2+2 \mathrm{lp}$ macrosetae; mesonotum with $1+1 \mathrm{ma}, 3+3 \mathrm{la}, 2+2 \mathrm{lp}, 1+1 \mathrm{mp}$ macrosetae; metanotum with $1+1 \mathrm{ma}, 1+1$ la, 2+2 lp, 1+1 mp macrosetae; long, barbed macrosetae; abundant notal clothing setae. Three ventral tibial macrosetae; unequal claws (1.4) with large lateral crests, posterior claw with a backward overhang. Urotergites I-III with $1+1$ post macrosetae; urotergite IV with $1+1$ la, $5+5$ post macrosetae; urotergites V-VII with $2+2$ la, $5+5$ post macrosetae; urotergite VIII with $6+6$ post macrosetae; urosternite I with $7+7$, urosternites II-VII with 5+5, urosternite VIII with $2+2$ macrosetae. Male without glandular $g_{1}$ setae on first urosternite. Female and male with subcylindrical appendages bearing glandular $a_{1}$ setae.

\section{Habitat and distribution}

Subterranean species reported from 10 caves, with a wide distribution area in the Austrian Alps.

Plusiocampa (Plusiocampa) strouhali cavicola Vornatscher, 1943

Figs 135-152; Table 11

Plusiocampa strouhali cavicola Vornatscher, 1943: 235.

\section{Differential diagnosis against the type form (Condé 1954a)}

Troglomorphic subspecies. Antennae with 25-28 antennomeres. Until now, the only character used to separate $P$. (P.) strouhali strouhali from $P$. $(P$.) strouhali cavicola has been the number of antennomeres (Condé 1954a). This characteristic had been used to sort out the subspecies (Vornatscher 1943; Strouhal \& Vornatscher 1975), and it was applied to the study material (see Table S2 in Supplementary Material). On the basis of this weak taxonomic character, the population from Odelsteinhöhle in the Gesäuse National Park, Austria has been classified as $P$. (P.) strouhali cavicola. 


\section{Description}

Troglomorphic subspecies. Body length: females 3.4-7 mm, males 3.45-6.15 mm, juveniles 2.95-3.7 mm. Epicuticle smooth under optical microscope; clothing setae thin, middle-sized, smooth or with a few distal barbs (Fig. 144). Antennae with 30-35 antennomeres in adults (Table 11). Length of antennae equal to or slightly shorter than body length in adults and juveniles. Sensillum of third
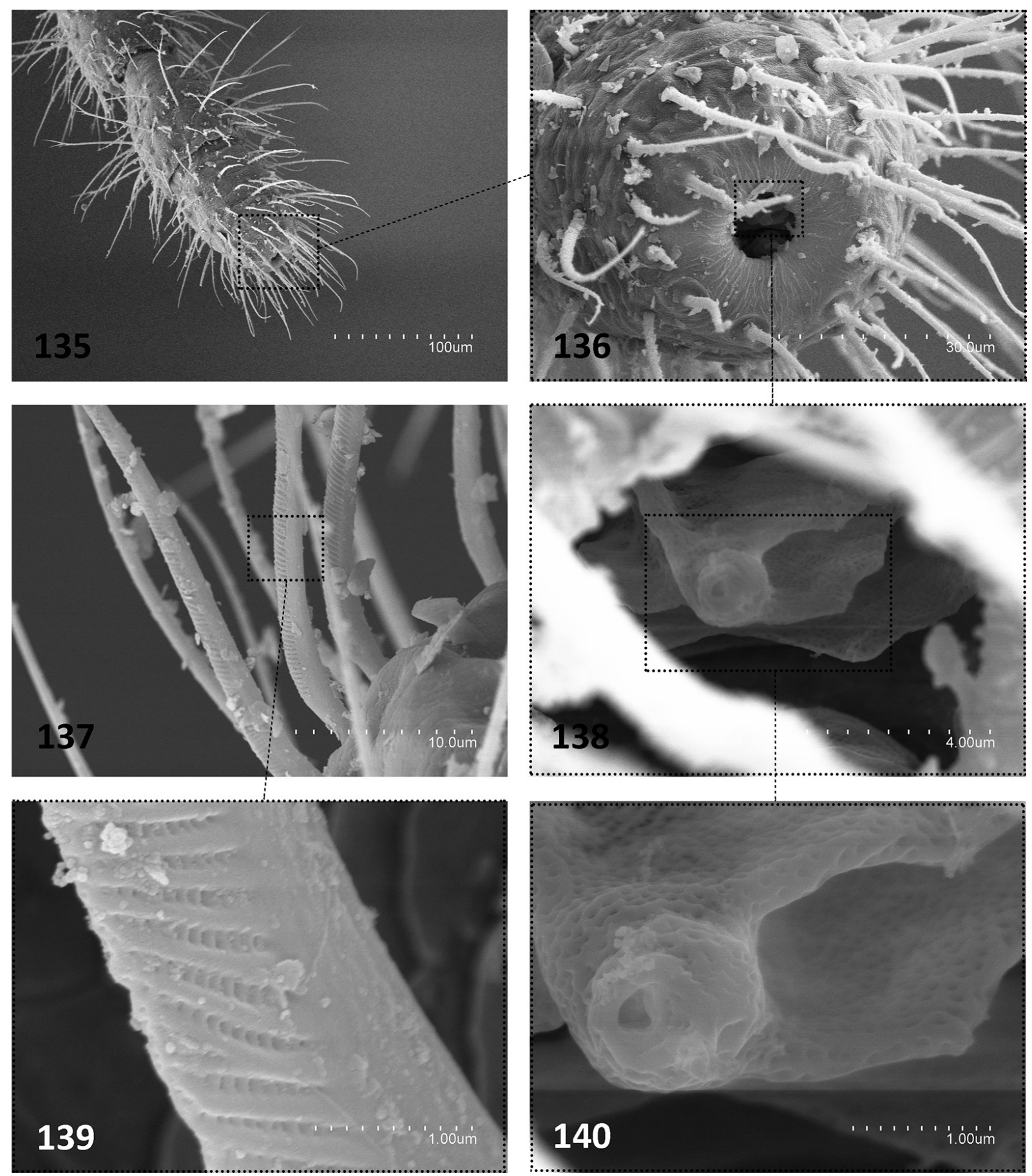

Figs 135-140. Plusiocampa (Plusiocampa) strouhali cavicola Vornatscher, 1943, from Odelsteinhöhle, Styria, Austria (Coll. AS). 135. Apical and distal antennomeres. 136. Tip of apical antennomere. 137. Lateral distal view of medial antennomere. 138. Olfactory chemoreceptor. 139. Medial portion of a gouge sensillum, detail. 140. Central portion of a gouge sensillum, detail. 


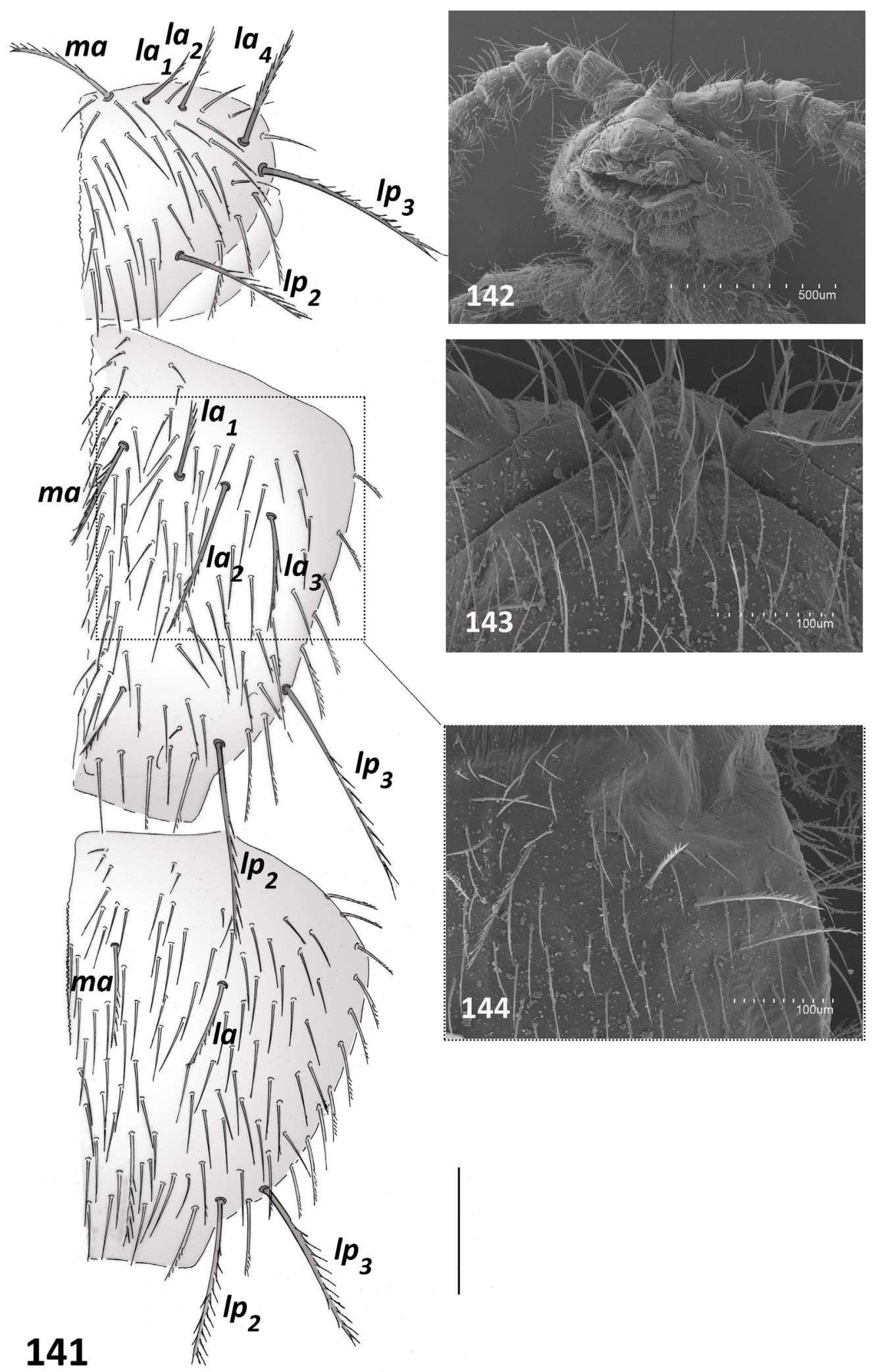

Figs 141-144. Plusiocampa (Plusiocampa) strouhali cavicola Vornatscher, 1943, from Odelsteinhöhle, Styria, Austria (Coll. AS). 141. Pronotum, mesonotum and metanotum, right side ( $s=$ setiform sensillum). 142. Head, frontal view. 143. Frontal process. 144. Detail of mesonotum, right side, with $m a$ and $l a_{l, 2,3}$ macrosetae. Scale bar: $141=0.2 \mathrm{~mm}$. 
antennomere subcylindrical, sharply pointed, in ventral position between macrosetae $d$ and $e$. Central antennomeres $1.6 \times$ as long as wide. Twelve to twenty thin gouge sensilla $(28-40 \mu \mathrm{m})$ in a single distal whorl on each medial and distal antennomere (Figs 137, 139-140). Cupuliform organ with 8-10 spheroidal olfactory chemoreceptors with a complex central structure surrounded by folds with visible polygonal net with porous surface (Figs 135-136, 138). Protruding frontal process with three distal, slightly tubercular macrosetae and a few posterior setae (Figs 142-143).

Notal macrosetae (Fig. 141): pronotum with $1+1 \mathrm{ma}, 3+3(3+2) 1 \mathrm{a}, 2+2 l p_{2,3}$; mesonotum with $1+1 \mathrm{ma}$, $3+3 l a_{1,2,3}, 2+2 l p_{2,3}, 1+1 \mathrm{smp}$ submacrosetae (or 1+1 $\mathrm{mp}$ ); metanotum with $1+1 \mathrm{ma}, 1+1 \mathrm{la}_{3}, 2+2 l p_{2,3}$, 1+1 mp; all notal macrosetae long, with long barbs along distal four-fifths (Fig. 144); marginal setae slightly longer than clothing setae, with thin barbs along distal half in lateral ones. Legs elongated, metathoracic legs reaching abdominal segment IX. Femur with one long dorsal macroseta, barbed along distal four-fifths. Tibia with 2-5 ventral macrosetae, barbed almost from base to tip. Calcars barbed from base to tip. Dorsal and lateral tarsal setae smooth. Unequal claws (1.1-1.4) with large lateral crests; ventral surface of claws noticeably ridged, dorsal surface slightly ridged but more evident on backward overhang of posterior claw; pretarsal processes smooth and setiform, with $0-4$ thin, small basal barbs (Figs 145-146, 148).
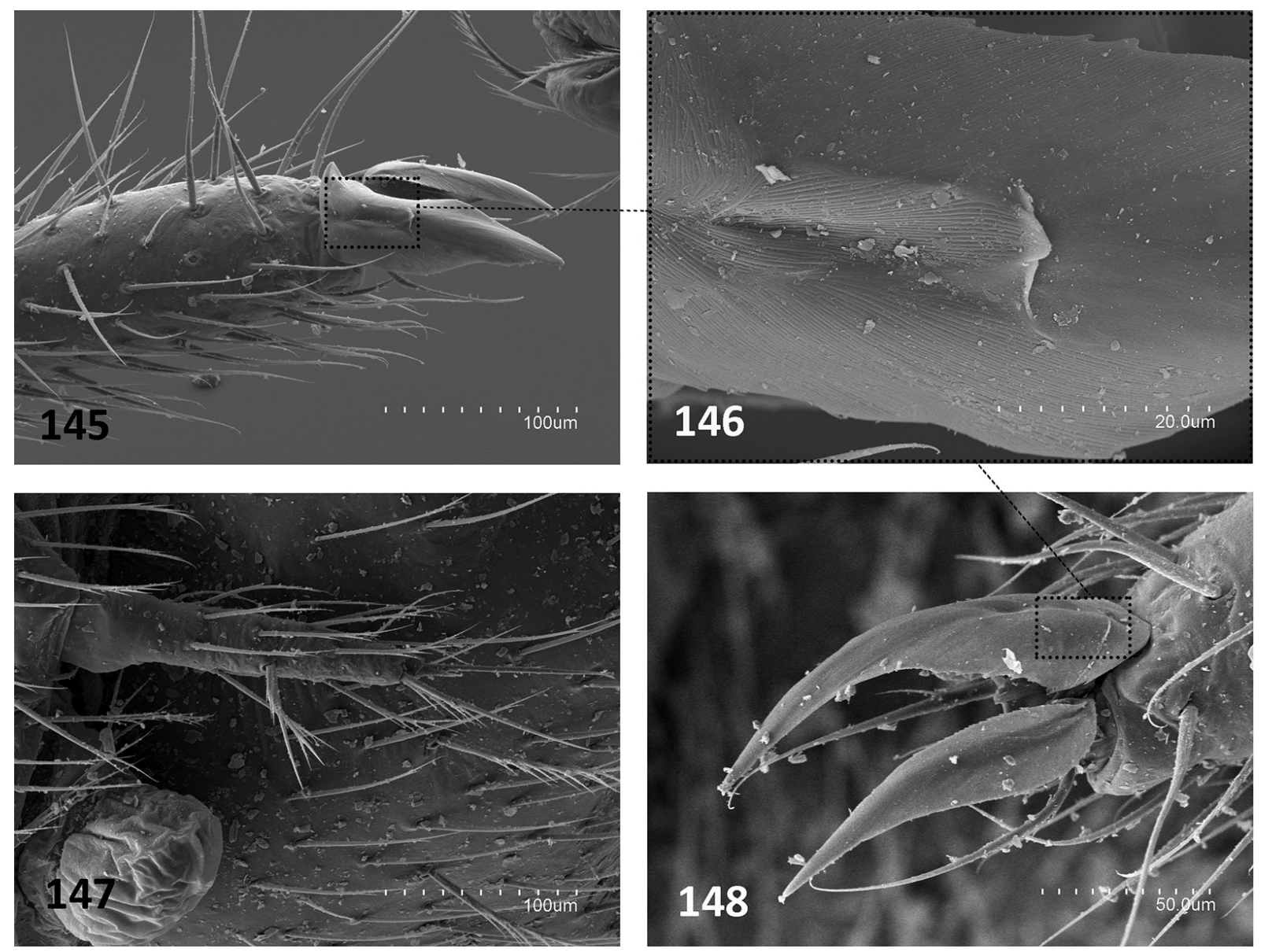

Figs 145-148. Plusiocampa (Plusiocampa) strouhali cavicola Vornatscher, 1943, from Odelsteinhöhle, Styria, Austria (Coll. AS). 145. Distal portion of tarsus and pretarsus. 146. Dorsal view of a posterior claw, detail. 147. Lateral portion of urosternite VI with stylus and abdominal eversible vesicle. 148. Pretarsus, laterodorsal view. 
Distribution of abdominal macrosetae on tergites (Figs 149-150): 1+1 post t $_{1}$ I-II; $1+1(0+0)$ la, $1+1$ post $_{1}$ on III; 1+1-2+2 la, $5+5$ (4+5) post ${ }_{1-5}$ on IV; $2+2$ la, $5+5$ post $_{1-5}$ on V-VII; 6+6 (7+6) post on VIII; $8+8-9+9$ post on abdominal segment IX. All post macrosetae long, covered with long barbs along distal four-fifths; la macrosetae shorter and less barbed than post macrosetae.

Urosternite I with 7+7, urosternites II-VII with 5+5, urosternite VIII with $2+2$ macrosetae. Apical setae of styli smooth, with basal tooth; subapical setae with 2-4 long proximal barbs; medial sternal setae with 4-6 long medial barbs (Fig. 147).

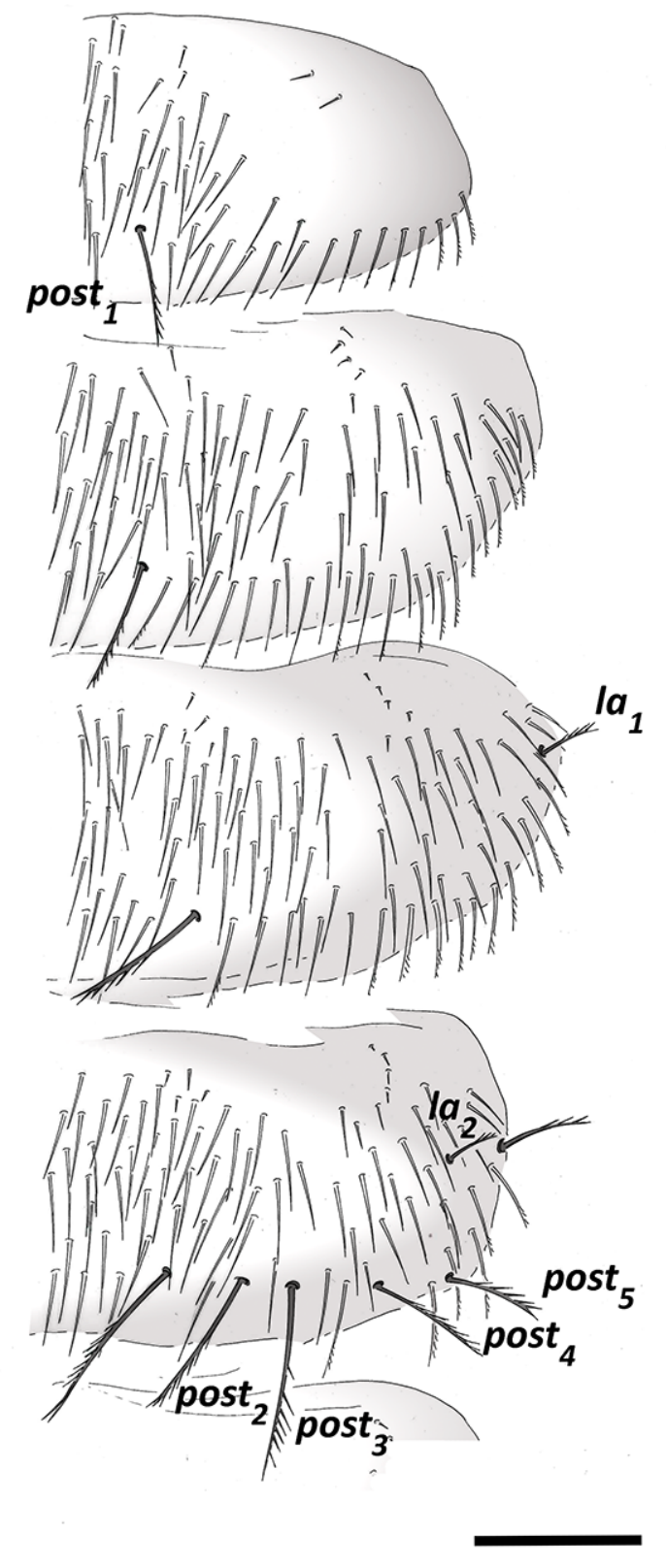

149
I

II

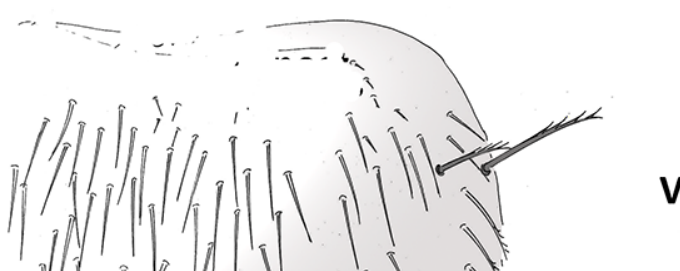

III

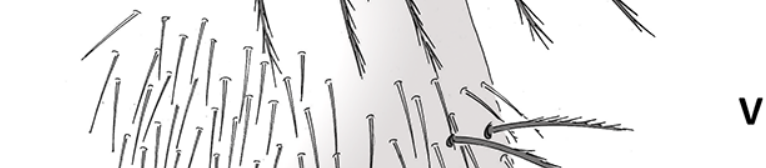

IV

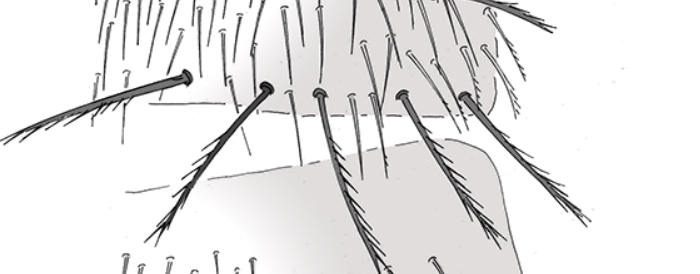

VII

VIII

IX

Figs 149-150. Plusiocampa (Plusiocampa) strouhali cavicola Vornatscher, 1943, from Odelsteinhöhle, Styria, Austria (Coll. AS). 149. Urotergites I-IV, right side. 150. Urotergites V-VIII and abdominal segment IX, right side ( $s=$ setiform sensillum). Scale bar: $0.2 \mathrm{~mm}$. 
Cerci up to $6.7 \mathrm{~mm}$ long (in $4.7 \mathrm{~mm}$ long female), with eight primary articles plus basal one, twice the length in juveniles (see Table 11). Articles with whorls of long macrosetae covered with thin barbs along distal two-thirds, combined with whorls of smooth, thin setae shorter than macrosetae.

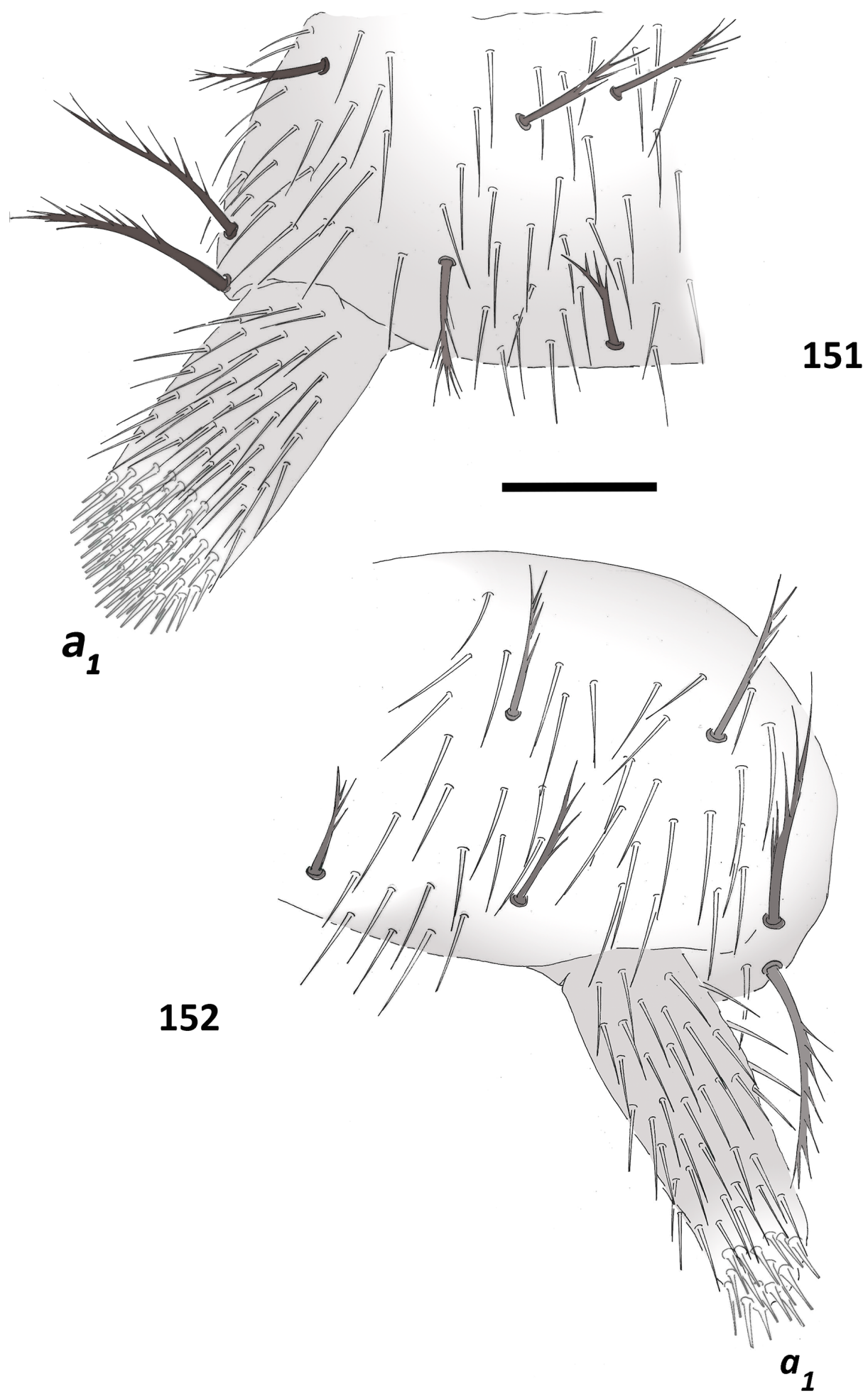

Figs 151-152. Plusiocampa (Plusiocampa) strouhali cavicola Vornatscher, 1943, from Odelsteinhöhle, Styria, Austria (Coll. AS). 151. $\sigma^{\lambda}, 6.3 \mathrm{~mm}$ long; urosternite I, right side. 152.,$+ 6.3 \mathrm{~mm}$ long; urosternite I, left side. Scale bar: $0.1 \mathrm{~mm}$. 
Table 11 (continued on next page). Plusiocampa (Plusiocampa) strouhali cavicola Vornatscher, 1943 from Odelsteinhöhle, Austria. Length of the body, antennae, metathoracic legs and cerci (measurements in $\mathrm{mm}$ ), in addition to the number of antennomeres and cercal articles.

\begin{tabular}{|c|c|c|c|c|c|c|}
\hline $\begin{array}{l}\text { Specimen } \\
\text { (Coll. AS) }\end{array}$ & $\begin{array}{l}\text { Body } \\
\text { length }\end{array}$ & $\begin{array}{c}\text { No. of } \\
\text { antennomeres }\end{array}$ & $\begin{array}{l}\text { Antennal } \\
\text { length }\end{array}$ & $\begin{array}{l}\text { Metathoracic } \\
\text { leg length }\end{array}$ & $\begin{array}{l}\text { No. of cercal } \\
\text { articles (base } \\
\text { included) }\end{array}$ & $\begin{array}{l}\text { Cercus } \\
\text { length }\end{array}$ \\
\hline juv. & 2.95 & 34 & 3.05 & 1.55 & - & - \\
\hline juv. & 3.10 & 34 & 3.00 & 1.80 & - & - \\
\hline juv. & 3.10 & 34 & 3.10 & 1.40 & - & - \\
\hline juv. & 3.15 & 32 & 3.10 & 1.45 & 5 & 2.70 \\
\hline juv. & 3.15 & 32 & 3.40 & 1.50 & - & - \\
\hline juv. & 3.20 & 34 & 2.90 & 1.50 & 6 & 4.00 \\
\hline juv. & 3.20 & 34 & 3.20 & 1.80 & 6 & 3.60 \\
\hline juv. & 3.30 & 34 & 3.25 & 1.70 & - & - \\
\hline juv. & 3.45 & 35 & 3.20 & 1.70 & - & - \\
\hline juv. & 3.70 & 33 & 3.10 & 1.60 & 6 & 3.60 \\
\hline juv. & 3.70 & 33 & 2.95 & 1.30 & 6 & 3.25 \\
\hline juv. & 3.90 & 35 & 3.35 & 1.60 & - & - \\
\hline q & 3.40 & 34 & 3.45 & 1.55 & - & - \\
\hline $0^{\lambda}$ & 3.45 & 33 & 3.35 & 1.80 & - & - \\
\hline q & 3.60 & 35 & 3.60 & 1.95 & - & - \\
\hline q & 3.70 & 34 & 3.20 & 1.90 & 6 & 3.40 \\
\hline$\hat{0}$ & 4.50 & 34 & 4.70 & 2.15 & - & - \\
\hline$q$ & 4.6 & - & - & 2.45 & 9 & 5.90 \\
\hline q & 4.70 & 31 & 4.95 & 2.60 & 9 & 6.70 \\
\hline$\hat{0}$ & 4.70 & 31 & 4.70 & 2.40 & - & - \\
\hline$\hat{0}$ & 4.80 & 35 & 4.40 & 2.30 & - & - \\
\hline q & 4.90 & 31 & 4.85 & 2.70 & - & - \\
\hline q & 5.00 & 35 & 5.50 & 2.70 & - & - \\
\hline$\hat{0}$ & 5.25 & 33 & 5.40 & 2.60 & - & - \\
\hline$\hat{0}$ & 5.30 & 31 & 4.50 & 2.45 & - & - \\
\hline q & 5.30 & 35 & 5.60 & 2.60 & - & - \\
\hline$\hat{\sigma}$ & 5.35 & 30 & 5.00 & 2.35 & 9 & 6.10 \\
\hline q & 5.40 & 33 & 4.90 & 2.50 & - & - \\
\hline$\hat{0}$ & 5.40 & 33 & 4.50 & 2.45 & - & - \\
\hline q & 5.40 & 32 & 5.10 & 2.50 & - & - \\
\hline q & 5.55 & 34 & 5.10 & 2.50 & - & - \\
\hline$\hat{0}$ & 5.60 & 35 & 5.10 & 2.50 & - & - \\
\hline$\hat{0}$ & 5.60 & 34 & 4.55 & 2.15 & - & - \\
\hline$\hat{0}$ & 5.60 & 31 & 4.85 & 2.65 & - & - \\
\hline$\hat{o}$ & 5.70 & 34 & 4.70 & 2.35 & - & - \\
\hline$\hat{0}$ & 5.80 & 34 & 5.10 & 2.55 & - & - \\
\hline
\end{tabular}


Table 11 (continued from preceding page). Plusiocampa (Plusiocampa) strouhali cavicola Vornatscher, 1943 from Odelsteinhöhle, Austria. Length of the body, antennae, metathoracic legs and cerci (measurements in $\mathrm{mm}$ ), in addition to the number of antennomeres and cercal articles.

\begin{tabular}{|c|c|c|c|c|c|c|}
\hline $\begin{array}{l}\text { Specimen } \\
\text { (Coll. AS) }\end{array}$ & $\begin{array}{l}\text { Body } \\
\text { length }\end{array}$ & $\begin{array}{c}\text { No. of } \\
\text { antennomeres }\end{array}$ & $\begin{array}{l}\text { Antennal } \\
\text { length }\end{array}$ & $\begin{array}{l}\text { Metathoracic } \\
\text { leg length }\end{array}$ & $\begin{array}{l}\text { No. of cercal } \\
\text { articles (base } \\
\text { included) }\end{array}$ & $\begin{array}{l}\text { Cercus } \\
\text { length }\end{array}$ \\
\hline$q$ & 5.90 & 34 & 5.30 & 2.75 & - & - \\
\hline$\hat{\sigma}$ & 6.00 & 32 & 4.80 & 2.60 & - & - \\
\hline$q$ & 6.10 & 31 & 4.70 & 2.50 & - & - \\
\hline 우 & 6.10 & 35 & 5.00 & 2.35 & - & - \\
\hline$\hat{0}$ & 6.15 & 34 & 5.10 & 2.60 & - & - \\
\hline q & 6.30 & 34 & 5.30 & 2.40 & - & - \\
\hline q & 6.30 & 31 & 5.00 & 2.60 & - & - \\
\hline 우 & 6.40 & 31 & 4.90 & 2.55 & - & - \\
\hline$q$ & 6.50 & 32 & 5.10 & 2.90 & - & - \\
\hline$q$ & 6.70 & 34 & 5.15 & 2.70 & - & - \\
\hline 우 & 7.00 & 32 & 5.10 & 2.70 & - & - \\
\hline
\end{tabular}

In males, urosternite I (Fig. 151) with large subcylindrical appendages, each bearing up to 60 glandular $a_{l}$ setae in a distal area. In females, urosternite I (Fig. 152) with subcylindrical appendages thinner than male appendages, each bearing up to 20 glandular $a_{1}$ setae in a distal area.

\section{Habitat and distribution}

Subterranean subspecies found in 21 caves in the Austrian Alps, where it is the common form in caves of the Northern Calcareous Alps. The areas of the two subspecies are overlapping, which casts serious doubt on the validity of the subspecies.

Plusiocampa (Plusiocampa) suspiciosa Condé \& Mathieu, 1957

Plusiocampa suspiciosa Condé \& Mathieu, 1957: 467, fig. xi, 45-52.

Diagnosis (Condé \& Mathieu 1957)

Non-troglomorphic species. Antennae with 20-21 antennomeres; four olfactory chemoreceptors in cupuliform organ; non-protruding frontal process with non-tubercular setae. Pronotum with $1+1 m a$, $3+3-2+1 l a, 2+2$ lp macrosetae; mesonotum with $1+1 \mathrm{ma}, 3+3 l a, 2+2 l p, 1+1 \mathrm{mp}$ macrosetae; metanotum with $1+1 m a, 2+2 l a, 2+2 l p, 1+1 m p$ macrosetae; long, barbed notal macrosetae; sparse smooth notal clothing setae. Two or three ventral tibial macrosetae; subequal small claws with small lateral crests, posterior claw with no backward overhang. Urotergites I-II with $2+2$ post macrosetae; urotergite III with $4+4$ post macrosetae; urotergites IV with $2+2$ la, $5+5$ post macrosetae; urotergites V-VII with $3+3$ $l a, 5+5$ post macrosetae; urotergite VIII with $6+6$ post macrosetae; abdominal segment IX with $8+8$ post macrosetae; urosternite I with $7+7$, urosternites II-VII with $5+5$, urosternite VIII with $2+2$ macrosetae. Male unknown; female with subcylindrical to conical appendages with glandular $a_{1}$ setae.

\section{Habitat and distribution}

The locatity of this species is still not clear, as a label confusion may have occurred between two localities, one endogean habitat in France (Tarn-et-Garonne, La Capelle-Livran, Caylus) and a small cave in Sicily (Scaletta Zanclea, south of Messina). 
Plusiocampa (Plusiocampa) ternovensis Sendra \& Borko sp. nov. urn:1sid:zoobank.org:act:D1AE6C14-8920-4505-9B42-B518BB1A6FB0

Figs 153-156; Table 12

\section{Etymology}

The specific name comes from the geographic area where this new species was found, the plateau called Trnovski gozd (Trnovo Forest).

\section{Material examined}

\section{Holotype}

SLOVENIA • +; Ajdovšćina, Predmeja, Bela Griža 1 n. 7937; 2 Oct. 2014; Špela Borko leg., PMSL Diplura-001.

\section{Paratypes}

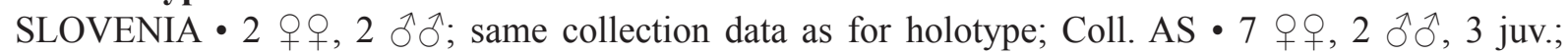
Ajdovšćina, Predmeja, Velika ledena jama v Paradani n. 742; Coll. AS • 1 đ̂; same collection data as for preceding; PMSL Diplura-002 • 1 क; same collection data as for preceding; PMSL Diplura-003.

\section{Other material}

See Table S2 in Supplementary Material.

\section{Description}

BoDy. Body length 3.9-5.4 mm (females), 3.2-4.35 mm (males) and 2.7-3.7 (juveniles). Epicuticle smooth under optical microscope; body with thin, middle-sized barbed clothing.

HEAD. Only two complete antennae, in a juvenile with 40 antennomeres. Bacilliform sensillum of third antennomere in ventral position between macrosetae $d$ and $e$. Central antennomeres $1.3 \times$ as long as wide. Eighteen to twenty thin gouge sensilla $(30-34 \mu \mathrm{m})$ in a single distal whorl on each medial and distal antennomere; 2-3 coniform sensilla in same whorl, but also present in last antennomere. Cupuliform organ on apical antennomere with about eight complex olfactory chemoreceptors. Nonprotruding frontal process, with non-tubercular setae.

Thorax. Pronotum with 1+1 ma, 4+4 la, 2+2 lp macrosetae; mesonotum with $1+1 \mathrm{ma}, 3+3 \mathrm{la}, 2+2$ lp macrosetae; metanotum with $1+1 \mathrm{ma}, 2+2(1+1,3+2) l a, 2+2$ lp macrosetae; long, barbed macrosetae; long, thin, barbed notal macrosetae; clothing setae smooth or with up to four distal thin barbs. One dorsal femoral macroseta, barbed all along with thin, short barbs; one barbed tibial metathoracic macroseta and none on prothoracic or mesothoracic tibiae; calcars with thin, long barbs in several rows; very unequal claws (1.7-1.8) with large lateral crests; posterior claw with a large backward overhang (Figs 153-154).

ABDOMEN. Urotergites I-III with $1+1$ post macrosetae; urotergite IV with $1+1(1+0)$ la, $3+3-2+2$ post macrosetae; urotergite $\mathrm{V}$ with $1+1(0+1)$ la, $4+4$ post macrosetae; urotergite VI with $1+1$ la, $4+4$ post macrosetae; urotergite VII with $2+2(2+1)$ la, $4+4$ post macrosetae; urotergite VIII with $6+6$ post macrosetae; abdominal segment IX with $8+8$ post macrosetae; urosternite I with $7+7-8+8$, urosternites II-VII with $6+6$, urosternite VIII with $2+2$ macrosetae. Stylus setae with a few barbs, smooth apically, with basal tooth; 3-5 thin distal barbs on subapical and mediosternal setae.

CERCI. Incomplete cerci, a maximum of 5 primary articles have been observed in several specimens. Each primary cercus bears from six to ten disorganized whorls of long, barbed macrosetae, one distal whorl of smooth, long setae and an apical whorl of short, thin setae. 
Genital ORgans. Male with two to four rows of up to 200 glandular $g_{l}$ setae, subcylindrical appendages with a small distal area of up to ten glandular $a_{1}$ setae; female with subcylindrical appendages with up to 8 glandular $a_{1}$ setae (Figs 155-156).

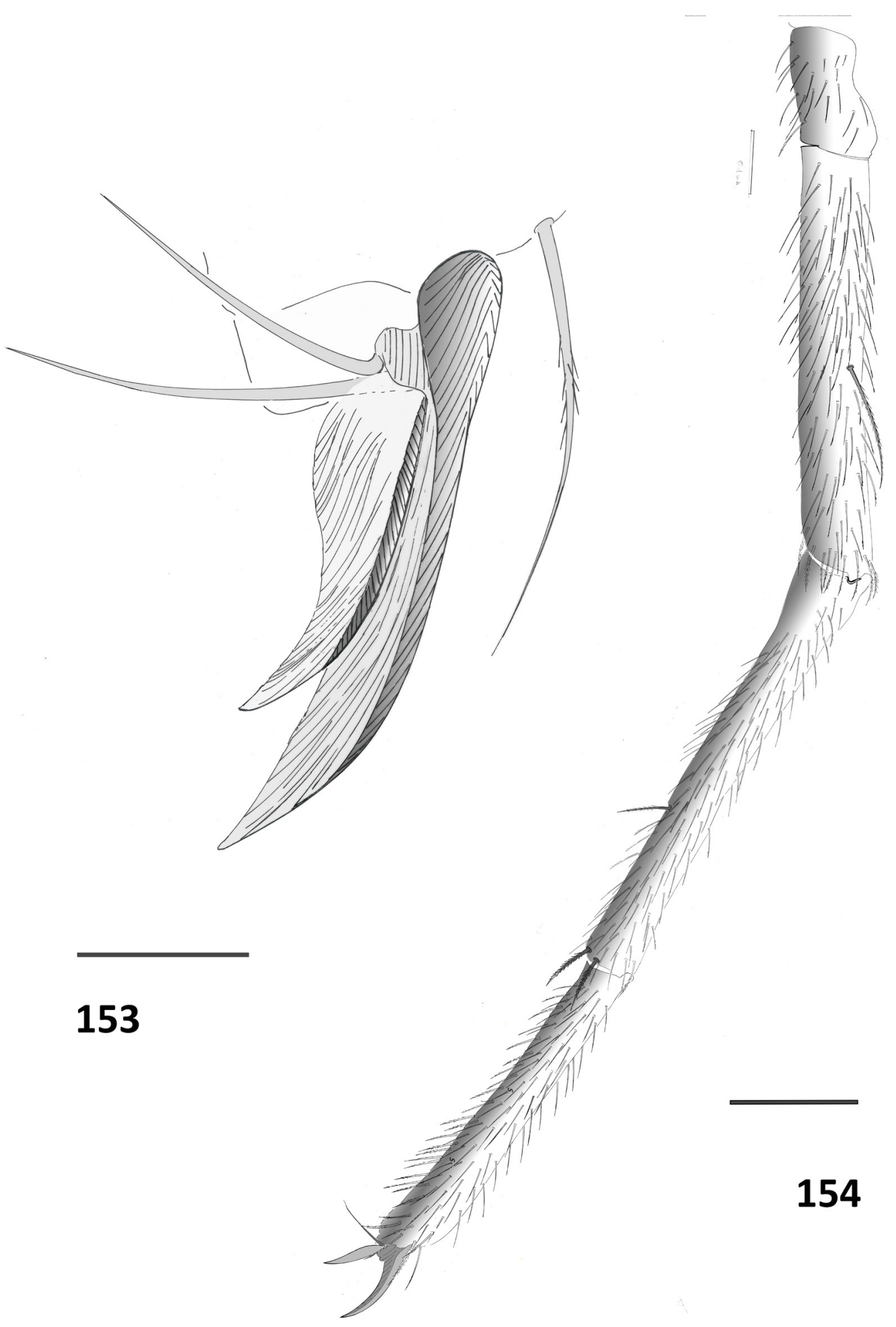

Figs 153-154. Plusiocampa (Plusiocampa) ternovensis Sendra \& Borko sp. nov., paratype,, , $4.4 \mathrm{~mm}$ long, from Velika ledena jama v Paradani, Predmeja, Slovenia (PMSL Diplura-003). 153. Metathoracic leg. 154. Metathoracic pretarsus, lateral anterior side. Scale bars: $153=100 \mu \mathrm{m} ; 154=50 \mu \mathrm{m}$. 


\section{Phyletic affinities, habitat and distribution}

Several species of Plusiocampa s. str. share important taxonomical features with $P$. (P.) ternovensis sp. nov., such as the clearly unequal claws with large lateral crests, the posterior claw with a backward overhang and the absence of medial posterior macrosetae on mesonotum and metanotum, but only $P$. (P.) balsani and $P$. (P.) affinis share a similar distribution pattern of notal and urotergal macrosetae. Nonetheless, the secondary sexual features of $P$. $(P$.) balsani, with the male having subtrapezoidal appendages and glandular $a_{2}$ setae, unambiguously isolate it from $P$. (P.) ternovensis sp. nov. Morphologically and geographically speaking, its closest related species is $P$. (P.) affinis, but some clear differences separate them. The very unequal claws (1.7-1.8), presence of only one ventral tibial macroseta and the $2+2$ lateral macrosetae on the urotergites are features of the new species that are not present in $P$. (P.) affinis, which has unequal claws (1.3), two ventral tibial macrosetae and $1+1$ lateral macrosetae on the urotergites.

Plusiocampa (P.) ternovensis sp. nov. has been sampled in three caves at the edge of a karst plateau north of the town of Ajdovščina, in Slovenia. This karst area is in the northern part of the Dinaric Mountains, a transitional zone between the Mediterranean, Alpine, Dinaric and Central European biogeographic regions. In two of the caves, the species lives together with $P$. (Stygiocampa) nivea, although they segregate differently within the cave. Plusiocampa (P.) ternovensis sp. nov. lives at a wider range of depths, while $P$. (S.) nivea occupies a deeper zone of the cave, at a depth of $500 \mathrm{~m}$ in the Velika ledena jama v Paradani and Bela Griža 1 caves. The temperatures in these two deep caves increase with depth, from permanently under $0^{\circ} \mathrm{C}$ (Velika ledena jama v Paradani, with permanent ice in the upper parts) to more than $4^{\circ} \mathrm{C}$ in parts deeper than $500 \mathrm{~m}$. In Ledenica pri Dolu, an ice cave with temperatures below $2^{\circ} \mathrm{C}$, we found only $P$. (P.) ternovensis sp. nov., while in the Bošnarjev brezen Cave $\left(5.9^{\circ} \mathrm{C}\right.$ to $\left.7.0^{\circ} \mathrm{C}\right)$ we found only $P$. $(S$.) nivea. This suggests that $P$. $(P$.) ternovensis sp. nov. may be considered better coldadapted than $P$. (S.) nivea.
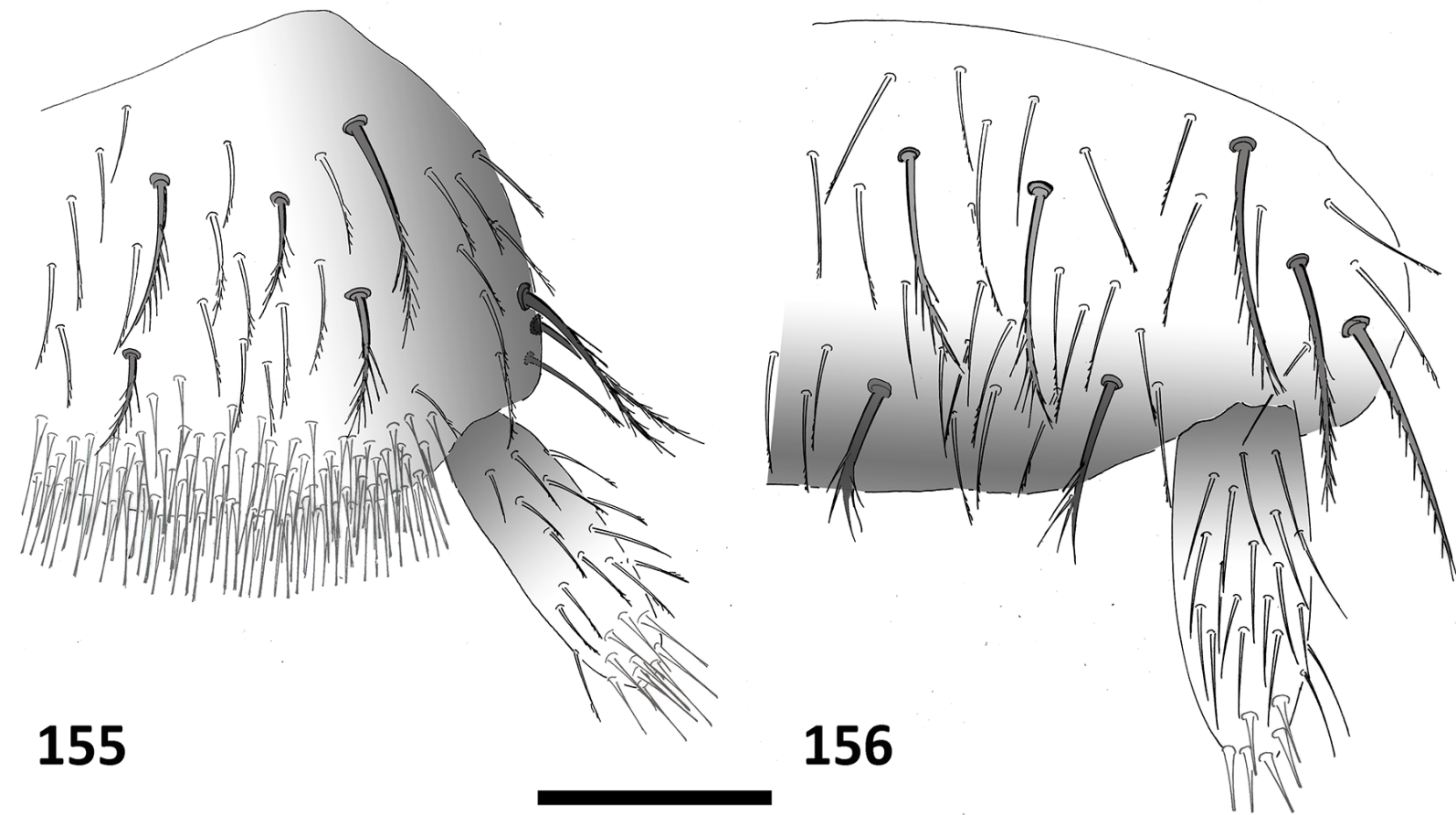

Figs 155-156. Plusiocampa (Plusiocampa) ternovensis Sendra \& Borko sp. nov. 155. Paratype, Ô, $4.7 \mathrm{~mm}$ long (PMSL Diplura-002); urosternite I, left side. 156.,$+ 5.3 \mathrm{~mm}$ long (Coll. AS); urosternite I, left side. Scale bar: $0.1 \mathrm{~mm}$. 
Table 12. Plusiocampa (Plusiocampa) ternovensis Sendra \& Borko sp. nov. Length of the body, femur, tibia and tarsus (including pretarsus) (measurements in $\mathrm{mm}$ ).

\begin{tabular}{|c|c|c|c|c|c|}
\hline Specimen & Depository & Body length & Femur & Tibia & Tarsus \\
\hline q 01 , paratype & Coll. AS & 4.4 & 0.70 & 0.72 & 0.72 \\
\hline 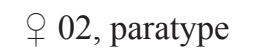 & Coll. AS & 3.9 & 0.75 & 0.80 & 0.78 \\
\hline q 03, paratype & Coll. AS & 4.6 & 0.76 & 0.83 & 0.72 \\
\hline , , holotype & PMSL Diplura-001 & 5.4 & 0.85 & 0.93 & 0.77 \\
\hline ㅇ 05, partype & PMSL Diplura-003 & 5.4 & 0.92 & 1.02 & 0.84 \\
\hline 96 , paratype & Coll. AS & 4.7 & 0.80 & 0.86 & 0.78 \\
\hline 907 , paratype & Coll. AS & 4.4 & 0.78 & 0.82 & 0.72 \\
\hline q 08 , paratype & Coll. AS & 4.2 & 0.78 & 0.87 & 0.78 \\
\hline juv. 01, paratype & Coll. AS & 2.7 & 0.44 & 0.46 & 0.50 \\
\hline$q 09$, paratype & Coll. AS & 5.3 & 0.85 & 1.04 & 0.81 \\
\hline$\widehat{o} 01$, paratype & PMSL Diplura-002 & 4.4 & 0.72 & 0.84 & 0.71 \\
\hline$\widehat{\jmath} 02$, paratype & Coll. AS & 3.2 & 0.65 & 0.70 & 0.68 \\
\hline juv. 02, paratype & Coll. AS & 3.0 & 0.65 & 0.72 & 0.68 \\
\hline juv. 03, paratype & Coll. AS & 3.7 & 0.64 & 0.72 & 0.68 \\
\hline q 10, paratype & Coll. AS & 5.0 & 0.84 & 1.02 & 0.80 \\
\hline
\end{tabular}

Plusiocampa (Plusiocampa) tinoamorei Sendra \& Nicolosi, 2019

Plusiocampa (Plusiocampa) tinoamorei Sendra \& Nicolosi in Sendra et al., 2019: 298, figs 1-22, tables $1-2 .$.

Diagnosis (Sendra et al. 2019)

Troglomorphic species. Antennae with 37-41 antennomeres. Very slight protruded frontal process with slightly differentiated smooth macrosetae. Pronotum with $1+1 m a, 4+4 l a, 2+2 l p$ macrosetae; mesonotum with $1+1 \mathrm{ma}, 3+3 \mathrm{la}, 2+2 \mathrm{lp}, 1+1 \mathrm{mp}$ macrosetae; metanotum with $1+1 \mathrm{ma}, 1+1 \mathrm{la}, 2+2$ $l p, 1+1 \mathrm{mp}$ macrosetae; long, barbed notal macrosetae; body with a small number of thin clothing setae with thin distal barbs. Two or three ventral tibial macrosetae; slightly unequal claws (1.08-1.12) with large lateral crests, posterior claw with backward overhang. Urotergites I-III with 1+1 post macrosetae; urotergite IV with $1+1$ la, $3+3$ post macrosetae; urotergites $\mathrm{V}-\mathrm{VII}$ with $1+1$ la, $5+5$ post macrosetae; urotergite VIII with $6+6(6+5)$ post macrosetae; abdominal segment IX with $8+8$ post macrosetae; urosternite I with $7+7$, urosternites II-VII with $5+5$, urosternite VIII with $2+2$ macrosetae. Stylar setae with a few thin barbs. Male with an area of glandular $g_{1}$ setae, subcylindrical appendages with glandular $a_{1}$ setae; appendages of female slightly thinner than those of male.

\section{Habitat and distribution}

Subterranean species found in three caves near Siracusa, southeastern Sicily.

Plusiocampa (Plusiocampa) vedovinii Condé, 1981

Plusiocampa vedovinii Condé, 1981b: 590, fig. 2.

Diagnosis (Condé 1981b)

Troglomorphic species. Antennae with 39 antennomeres; eight simple olfactory chemoreceptors in cupuliform organ, highly likely regenerated; non-protruding frontal process with non-tubercular setae. 
Pronotum with $1+1 m a, 2+2 l a, 2+2$ lp macrosetae; mesonotum with $1+1 m a, 1+1 l a, 2+2 l p$ macrosetae; metanotum with $1+1 \mathrm{ma}, 1+1 \mathrm{lp}$ macrosetae; long, barbed notal macrosetae. Two ventral tibial macrosetae; unequal claws with large lateral crests. Urotergite IV with $1+1$ la $1+0$ post macrosetae; urotergites V-VII with $1+1$ la, $3+3$ post macrosetae; urotergite VIII with $6+6$ post macrosetae; abdominal segment IX with $8+8$ post macrosetae; urosternite I with $7+7$, urosternites II-VII with $5+5$, urosternite VIII with $2+2$ macrosetae. Male unknown; female with subcylindrical appendages bearing glandular $a_{l}$ setae.

\section{Habitat and distribution}

Subterranean species found in Grouffre des Encanaux, Auriol, Sainte-Baume Massif, Bouches-duRhône, southeastern France.

Plusiocampa (Plusiocampa) vodniensis Bareth \& Condé, 2001

Plusiocampa vodniensis Bareth \& Condé, 2001: 18, figs 5-6.

Diagnosis (Bareth \& Condé 2001)

Troglomorphic species. Antennae with 31, 36 and 38 antennomeres; six simple olfactory chemoreceptors on cupuliform organ; protruding frontal process with tubercular setae. Pronotum with $1+1 m a, 3+3 l a$, $2+2 l p$ macrosetae; mesonotum $1+1 \mathrm{ma}, 3+3 \mathrm{la}, 2+2 \mathrm{lp}, 1+1 \mathrm{mp}$ macrosetae; metanotum with $1+1 \mathrm{ma}$, $2+2 l a, 2+2 l p, 1+1 \mathrm{mp}$ macrosetae; long, barbed notal macrosetae; clothing setae abundant, smooth or with a few distal barbs. Two or three ventral tibial macrosetae; unequal claws with large lateral crests, posterior claw with a backward overhang. Urotergites I-III with 1+1 post macrosetae; urotergites IV-V with $1+1$ la $4+4$ post macrosetae; urotergites VI-VII with $2+2$ la, $4+4$ post macrosetae; urotergite VIII with $6+6$ post macrosetae; abdominal segment IX with $8+8$ post macrosetae; urosternite I with $7+7$, urosternites II-VII with $5+5$, urosternite VIII with $2+2$ macrosetae. Male unknown.

\section{Habitat and distribution}

Subterranean species known only from the Vodni Pech Cave, Vidin town area, in the Balkan Mountains, Bulgaria.

Subgenus Stygiocampa Silvestri, 1934

Stygiocampa Silvestri, 1934: 180.

Diagnosis (Condé \& Bareth 1996; Bareth \& Condé 2001)

No dorsal femoral macrosetae; without medial posterior notal macrosetae and with an overall reduction in mesonatal and metanotal macrosetae; extra macrosetae on first to eighth urosternites (with the exception of Plusiocampa (Stygiocampa) bureschi Silvestri, 1931 and P. (S.) denisi Condé (1947).

\section{Habitat and distribution}

Subterranean subgenus found almost exclusively in the Dinaric Mountains, but also in part of the Balkan Mountains (Fig. 211).

Plusiocampa (Stygiocampa) bureschi Silvestri, 1931

Plusiocampa bureschi Silvestri, 1931b: 100, figs iii-v.

Plusiocampa (Stygiocampa) rauseri Rusek, 1965: 94, figs 18-24.

Diagnosis (Silvestri 1931b; Condé 1955a, 1959; Condé \& Bareth 1996; Bareth \& Condé 2001)

Troglomorphic species. Antennae with 39-54 antennomeres; seven to nine complex olfactory chemoreceptors in cupuliform organ. Pronotum with $1+1 m a, 2+2 l a, 2+2 l p$ macrosetae; mesonotum with 
1+1 ma, 1+1 lp macrosetae; metanotum without macrosetae; long, barbed notal macrosetae; abundant notal clothing setae. No ventral tibial macrosetae; slightly unequal claws (1.1) with large lateral crests, posterior claw with a small backward overhang. Urotergite VII with $2+2$ post macrosetae; urotergite VIII with 4+4 post macrosetae; abdominal segment IX with $6+6-7+7$ post macrosetae; urosternite I with $7+7$, urosternites II-VII with $5+5$, urosternite VIII with $2+2$ macrosetae. Male without glandular $g_{1}$ setae, subcylindrical slightly enlarged appendages with glandular $a_{1}$ setae; female with subcylindrical appendages with glandular $a_{1}$ setae. Spermatozoid fascicles $50 \mu \mathrm{m}$ in diameter, $25 \mu \mathrm{m}$ wide; wheels with $3 \frac{1}{2}$ turns of $300-350 \mu \mathrm{m}$ and $5.6 \mu \mathrm{m}$ diamter filament.

\section{Habitat and distribution}

Subterranean species found in 13 caves in a karst region on the left bank of the Iskar River, Sofia District, Balkan Mountains, Bulgaria.

Plusiocampa (Stygiocampa) christiani Condé \& Bareth, 1996

Fig. 202

Plusiocampa (Stygiocampa) christiani Condé \& Bareth, 1996: 374, figs 1, 3, 4e, tables 1-4.

Diagnosis (Condé \& Bareth 1996)

Troglomorphic species. Antennae with 29-33 antennomeres; 12-14 complex olfactory chemoreceptors in cupuliform organ; protruding frontal process with non-tubercular setae. Pronotum with $1+1 \mathrm{ma}, 2+2$ la, $1+1$ lp macrosetae; mesonotum with $0+0-1+1$ sla macrosetae; metanotum without macrosetae; long, barbed macrosetae; abundant barbed notal clothing setae. No ventral tibial macrosetae; unequal claws (1.35) with large lateral crests, posterior claw with a large backward overhang. Urotergite VII with $0+0$ $1+1$ post macrosetae; urotergite VIII with $3+3-2+2$ post macrosetae; abdominal segment IX with $7+7$ post macrosetae; urosternite I with $21+21-29+25$, urosternites II-VII with $11+11-14+12$, urosternite VIII with $4+4(3+3,4+5)$ macrosetae. Male without glandular $g_{l}$ setae, thick slightly short subcylindrical appendages without glandular $a_{2}$ setae; female with subcylindrical appendages without glandular $a_{2}$ setae. Spermatozoid fascicles $50 \mu \mathrm{m}$ in diameter and $10-12 \mu \mathrm{m}$ wide; wheels with $1 \frac{1}{2}$ turns of $140-150 \mu \mathrm{m}$ long filament.

\section{Remarks}

The study of 26 specimens collected from three caves (see Table S2 in Supplementary Material) allowed us to add characters to the diagnosis (Coll. AS).

\section{Habitat and distribution}

Subterranean species found in several caves in the Kučaj and Beljanica Mountains, eastern Serbia Balkan System (Fig. 202).

Plusiocampa (Stygiocampa) dalmatica Condé, 1959

Figs 205, 208

Plusiocampa dalmatica Condé, 1959: 48, fig. 2.

Diagnosis (Condé 1959; Bareth 1988; Condé \& Bareth 1996)

Troglomorphic species. Antennae with 41-47 antennomeres; numerous sheet-shaped complex olfactory chemoreceptors in cupuliform organ; protruding frontal process with tubercular setae. Pronotum with $1+1 m a, 3+3-4+4 l a, 2+2 l p$ macrosetae; mesonotum with $1+1 m a, 2+2 l a, 2+2 l p$ macrosetae; metanotum with $1+1 m a, 1+1 l a, 2+2 l p$ macrosetae; long, barbed notal macrosetae; long, barbed notal 
clothing setae. No ventral tibial macrosetae; unequal claws with large lateral crests, posterior claw with a backward overhang. Urotergite III with $0+0-1+1(1+0)$ la macrosetae; urotergite IV with $1+1$ la, $0+1$ post macrosetae; urotergite V with $1+1$ la, $4+4(3+4)$ post macrosetae; urotergites VI-VII with $1+1$ la, 4+4 post macrosetae; urotergite VIII with 5+5-6+6 post macrosetae; abdominal segment IX with $8+8-$ $9+9(10+9)$ post macrosetae. Urosternite I with 14+15-21+20, urosternites II-VII with 9+9-12+12, urosternite VIII with 2+2-3+3 macrosetae. Male with lateral expansions of posterior margin occupied by an area of glandular $g_{1}$ setae in adults (no expansion in juveniles and little expansion in young males), subcylindrical appendages without glandular $a_{2}$ setae; female with subcylindrical appendages with glandular $a_{1}$ setae.

\section{Remarks}

The studied material (see Table S2 in Supplementary Material) allowed us to make additions to the diagnosis (Coll. AS).

\section{Habitat and distribution}

Subterranean species well distributed around the northwestern Dinaric Mountains, found in 18 caves (Figs 205, 208).

\section{Plusiocampa (Stygiocampa) denisi Condé, 1947}

Plusiocampa denisi Condé, 1947a: 21, fig. 2.

Diagnosis (Condé 1947a)

Troglomorphic species. Antennae with 29-34 antennomeres. Pronotum with $1+1 \mathrm{ma}, 3+3 \mathrm{la}, 1+1 \mathrm{lp}$ macrosetae; mesonotum with $1+1 \mathrm{ma}, 1+1-2+1-2+2 l a, 1+1 \mathrm{lp}$ macrosetae; metanotum with $1+1 \mathrm{ma}$ macrosetae; long, barbed notal macrosetae, abundant notal clothing setae, smooth or with a few distal barbs. Two ventral tibial macrosetae. Unequal claws with large lateral crests, posterior claw with a backward overhang. Urotergite IV with $1+1$ la, $1+1$ post macrosetae; urotergite $\mathrm{V}$ with $1+1$ la, $2+2$ post macrosetae; urotergites VI-VII with $1+1$ la, $4+4$ post macrosetae; urosternite I with $7+7$, urosternites II-VII with 5+5, urosternite VIII with $2+2$ macrosetae. Male with a large area with glandular $g_{1}$ setae, subcylindrical appendages with glandular $a_{1}$ setae; female appendages like those of male.

\section{Habitat and distribution}

Subterranean species found in the Pećina u Hamidovoj vrtači and Špela Hajnet (= Špela Maja Hajnet) caves in southwestern Serbia, Dinaric Mountains.

Plusiocampa (Stygiocampa) nivea (Joseph, 1882)

Figs 157-180, 207

Campodea nivea Joseph, 1882: 25.

Campodea erebophila Hamann, 1896: 153, figs i-ii, table 3.

Diagnosis (Denis 1923; Condé 1947a, 1959; Silvestri 1947; Bareth 1968)

Troglomorphic species. Antennae with 28-36 antennomeres; abundant sheet-shaped olfactory chemoreceptors in cupuliform organ; protruding frontal process with tubercular setae. Pronotum with $1+1 \mathrm{ma}, 3+3-4+4 l a, 2+2 l p$ macrosetae; mesonotum with $1+1 l a, 2+2(3+2) l p$ macrosetae; metanotum with $2+2$ lp macrosetae; long, barbed notal macrosetae; abundant barbed notal clothing setae. No ventral tibial macrosetae; unequal claws (1.35) with large lateral crests, posterior claw with a backward overhang. Urotergite IV with $0+0-1+1$ la macrosetae; urotergites V-VII with $1+1$ la, $4+4$ post macrosetae; urotergite VIII with 5+5-6+6 post macrosetae; abdominal segment IX with $8+8-9+9$ 
$(9+10)$ post macrosetae; urosternite I with $11+1+11-15+15(15+16)$, urosternites II-VII with $11+11-$ $14+14$, urosternite VIII with 2+2-4+4 macrosetae. Male without glandular $g_{l}$ setae, thick subcylindrical appendages without glandular $a_{2}$ setae; female with subcylindrical appendages without glandular $a_{2}$ setae.
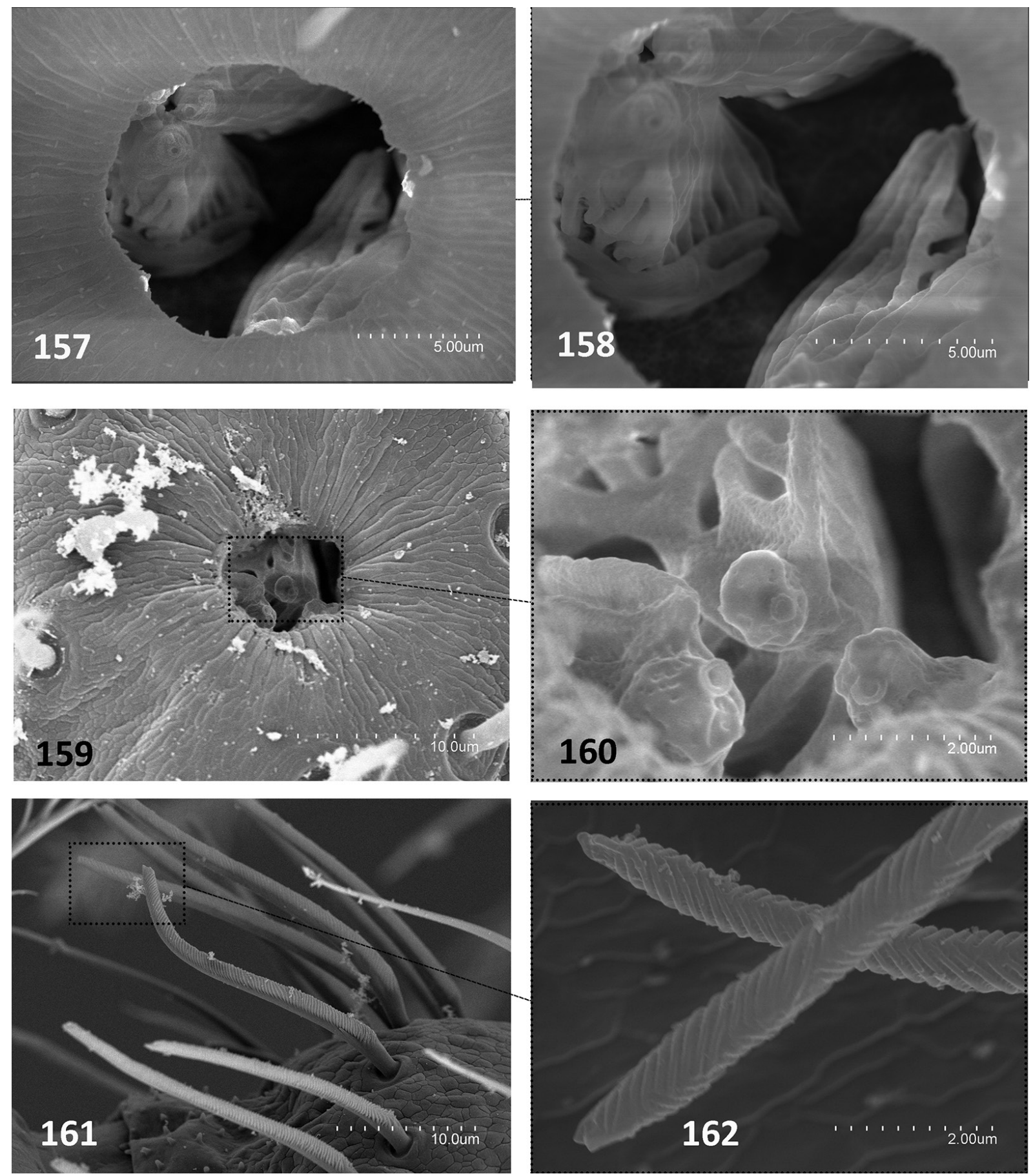

Figs 157-162. Plusiocampa (Stygiocampa) nivea (Joseph, 1882), from Habečkov Brezen, Idrijski Log Idrija, Slovenia (157-158), Velika ledena jama v Paradani, Predmeja, Slovenia $(159-160,162)$ and Volčja jama, Postojna, Slovenia (161) (Coll. AS). 157. Cupuliform organ. 158. Olfactory chemoreceptors. 159. Cupuliform organ. 160. Olfactory chemoreceptors. 161. Lateral distal portion of a medial antennomere. 162. Distal portion of two gouge sensilla. 


\section{Remarks}

The new material studied (see Table S2 in Supplementary Material) allowed the addition of minor taxonomic details revealed by SEM microscopy. The epicuticle, apparently smooth in optical microscopy, shows a subtle reticulate surface (Figs 166, 168) covered by well-barbed clothing setae (Figs 167-168). The macrosetae are also well barbed, but the multi-barbed urosternal macrosetae (Figs 169-170) are
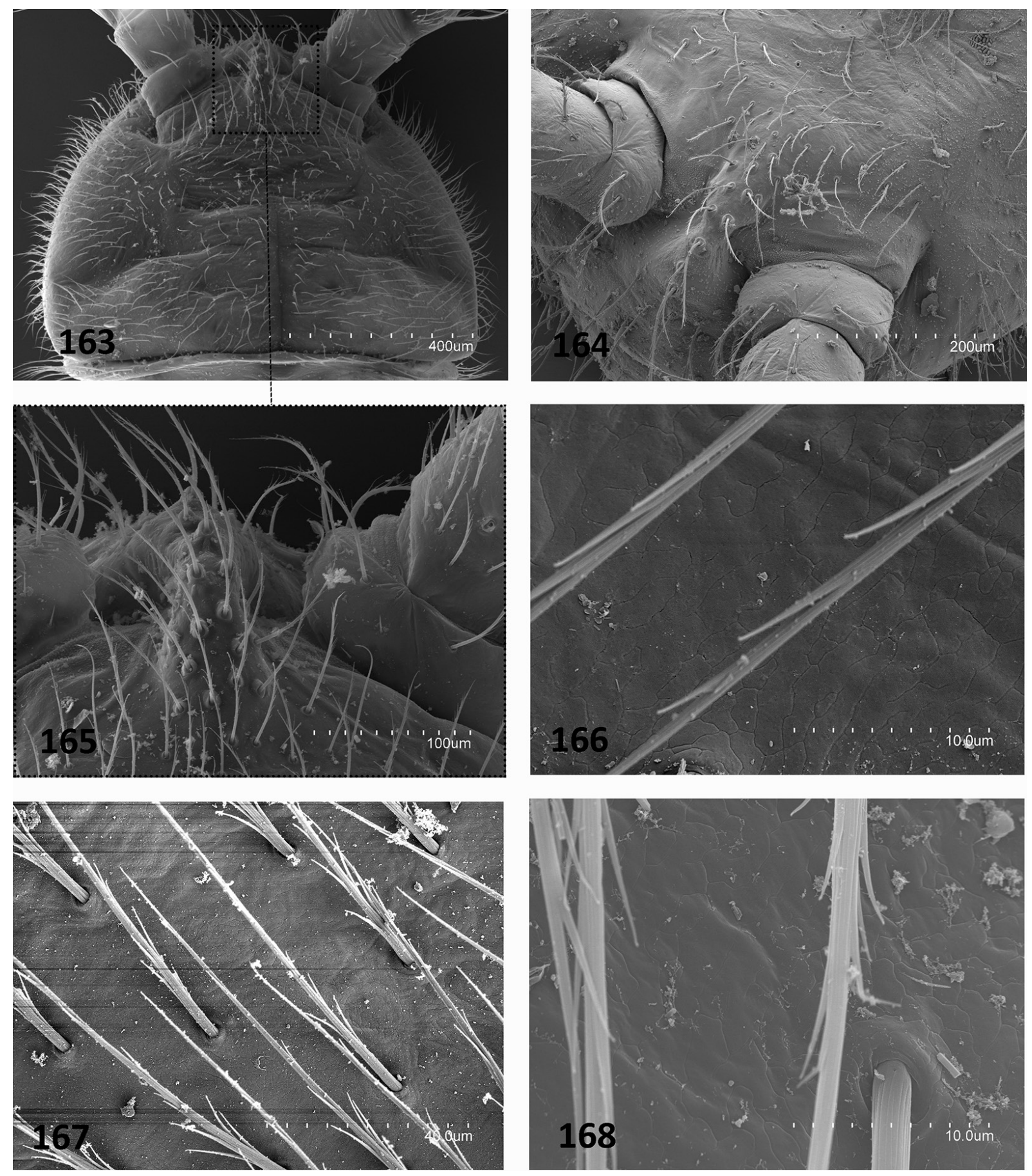

Figs 163-168. Plusiocampa (Stygiocampa) nivea (Joseph, 1882), from Velika ledena jama v Paradani, Predmeja, Slovenia (163-166, 168) and Volčja jama, Postojna, Slovenia (167) (Coll. AS). 163. Head, dorsal view. 164. Head, lateral frontal view. 165. Frontal process. 166. Surface of mesonotum, detail. 167. Clothing setae of metonotum. 168. Surface of metanotum, detail. 
remarkable. The gouge sensilla are abundant and as long as $28 \mu \mathrm{m}$, with transversal stripes in a V shape (Figs 161-162). The cupuliform organ has a narrow hole that does not allow an adequate observation of the olfactory chemoreceptors; however, these can be described under the optical microscope as having a multiple laminal shape and under SEM as a central structure with a pronounced terminal pore,
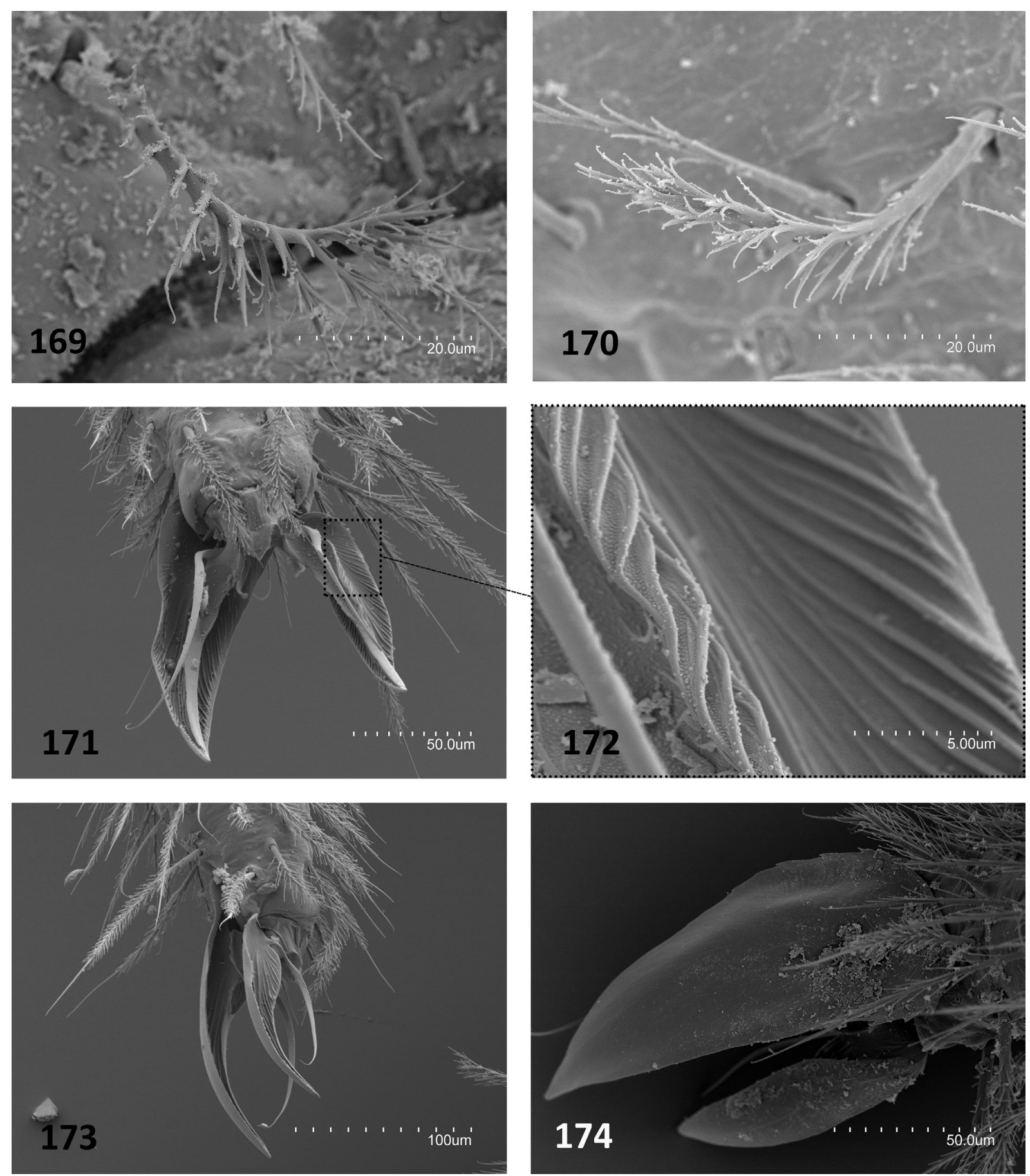

Figs 169-174. Plusiocampa (Stygiocampa) nivea (Joseph, 1882), from Velika ledena jama v Paradani, Predmeja, Slovenia (169, 171-174) and Jabčina (Pećina Jabčinov stržen), Račice, Podgrad, Slovenia (170) (Coll. AS). 169. Macrosetae on urosternite I. 170. Macrosetae on urosternite I. 171. Pretarsus, ventral view. 172. Ventral side of claw, detail. 173. Lateral side of pretarsus with anterior claw in the foreground. 174. Pretarsus, dorsal side. 
semiradially and irregularly folded (Figs 157-160). The protruding frontal process with tubercular setae is clearly visible under SEM (Figs 163-165). Claws have well-developed lateral crests with a complex, grooved ventral surface (Figs 171-174). The completely barbed abundant macrosetae and setae cover the entire surface of the sternites (Figs 169-170). The entire length of the stylar setae is totally covered
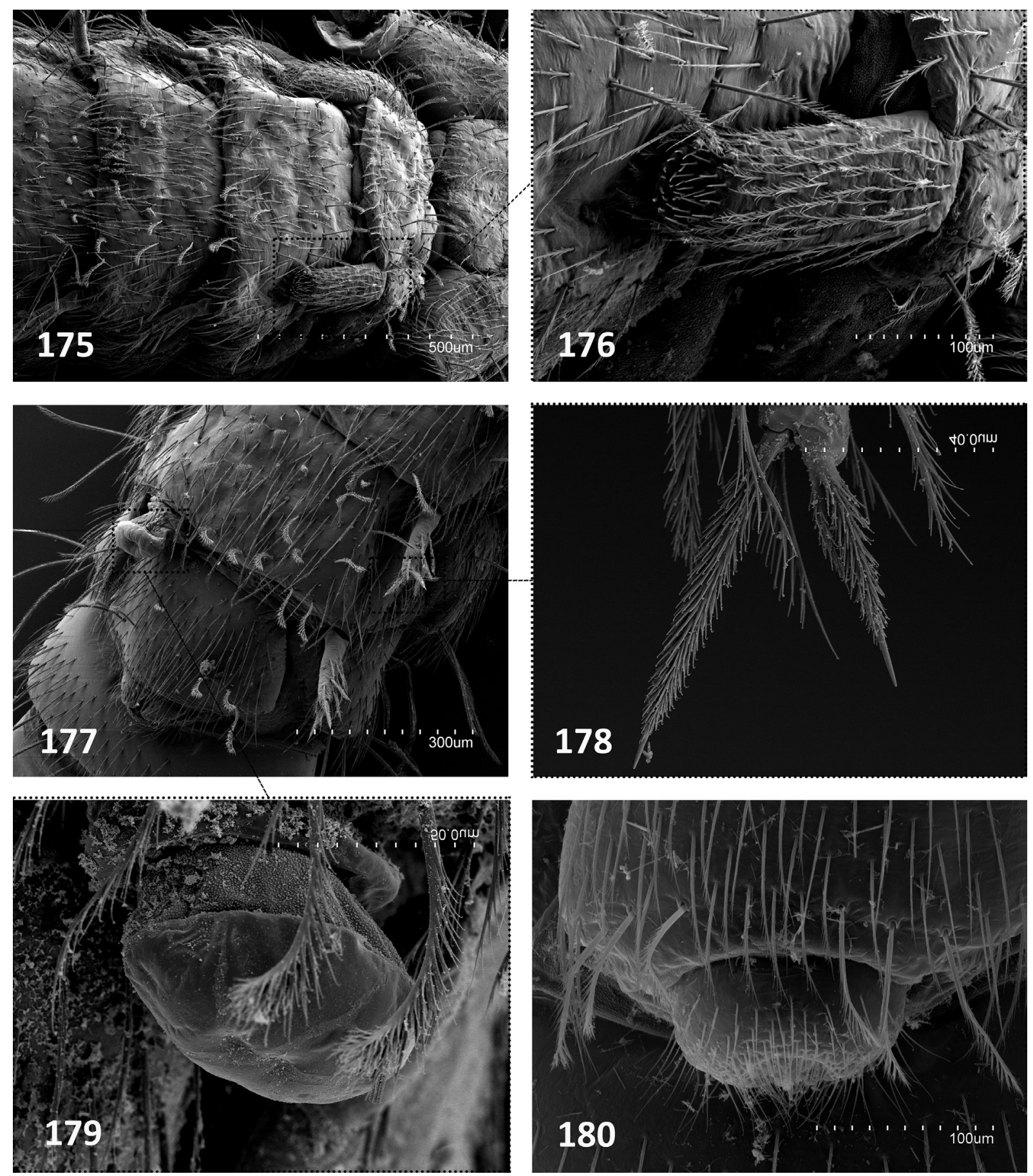

Figs 175-180. Plusiocampa (Stygiocampa) nivea (Joseph, 1882), from Volčja Jama, Postojna, Slovenia (175-177), Velika ledena jama v Paradani, Predmeja, Slovenia (178-179) and Roupa Cave, Banjščice,

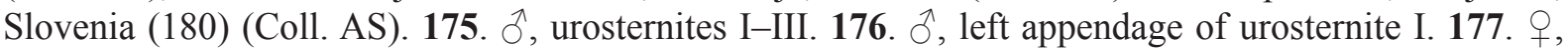
urosternites VII-VIII. 178. Apical and subapical setae on abdominal stylus. 179. Abdominal eversible vesicle. 180. ${ }^{\lambda}$, urosternite VIII. 
by barbs (Figs 177-178) and the eversible vesicles are large (Fig. 179). Males have large subcylindrical appendages with a large area of glandular $a_{1}$ setae (Figs 175-176, 180).

\section{Habitat and distribution}

Subterranean species, well distributed around the northwestern Dinaric Mountains, so far found in 75 caves (Fig. 207).

Plusiocampa (Stygiocampa) remyi Condé, 1947

Figs 181-192

Plusiocampa remyi Condé, 1947a: 17, fig. 1.

Diagnosis (Condé 1947a; Condé \& Bareth 1996)

Troglomorphic species. Antennae with 46-52 antennomeres; abundant sheet-shaped olfactory chemoreceptors in cupuliform organ; protruding frontal process with tubercular setae. Pronotum with $1+1 \mathrm{ma}, 3+3-4+4 l a, 2+2$ lp macrosetae; mesonotum with 1+1 la, 2+2 lp macrosetae; metanotum with $2+2$ lp macrosetae; barbed notal macrosetae; clothing setae abundant, completely barbed. No ventral tibial macrosetae; unequal claws with large crests, posterior claw with a backward overhang. Urotergite III with $1+1(0+1)$ la macrosetae; urotergite IV with $1+1$ la macrosetae; urotergites V-VII with $1+1$ la, $3+3$ post macrosetae; urotergite VIII with $5+5$ post macrosetae; abdominal segment IX with $9+9-11+11$ post macrosetae; urosternite I with 17+17-22+22, urosternites II-VII with 13+13-19+19, urosternite VIII with 3+3-6+6 macrosetae. Male with lateral expansions of posterior margin occupied by an area of glandular $g_{1}$ setae in adults (no expansions in juveniles and small expansions in young males), subcylindrical appendages without glandular $a_{2}$ setae; females with long subcylindrical appendages without glandular $a_{2}$ setae.

\section{Remarks}

The studied material (see Table S2 in Supplementary Material) allowed the addition of information to the diagnosis. The specimens from Njegoš pećina, Njeguši (Kotor, Montenegro) and Đatlo pećina, Lebršnik, Gacko (Bosnia and Herzegovina) revealed new diagnostic characters in SEM microscopy: antennomeres with a whorl of thin gouge sensilla, 40-47 $\mu \mathrm{m}$ long with an external transversal striped surface in a V pattern (Figs 181-182, 184), claws with large lateral crest with ventral longitudinal grooves separated by reticulate surfaces (Figs 183, 185-186). The first urosternite of the adult male has lateral expansions, bearing plenty of glandular $g_{1}$ setae (Figs 187-188), and abundantly long and completely barbed urosternal macrosetae (Figs 189, 192), like the stylar setae (Fig. 190), and similar to but thinner than the cercal macrosetae (Fig. 191).

\section{Plusiocampa (Stygiocampa) aff. remyi Condé, 1947}

\section{Differential diagnosis against the type form (Condé \& Bareth 1996)}

Antennae with 50 antennomeres; urosternite without lateral expansions, with a large area of glandular $g_{I}$ setae; enlarged subcylindrical appendages with a distal glandular $a_{1}$ seta.

\section{Habitat and distribution}

Subterranean species widespread in 21 caves of karst regions of the southeastern Dinaric Mountains. Plusiocampa (S.) aff. remyi occurs in Vranjača (cave), Croatia.

\section{Subgenus Venetocampa Bareth \& Condé, 1984}

Venetocampa Bareth \& Condé, 1984: 143. 


\section{Diagnosis (Bareth \& Condé 1984)}

Mesonotum with $1+1 \mathrm{ma}, 2+2$ la, $2+2$ lp macrosetae; metanotum with $1+1 \mathrm{ma}, 1+1 \mathrm{lp}$ or $1+1 \mathrm{ma}, 1+1$ $l a, 2+2 l p$ macrosetae; without $m p$ notal macrosetae. One dorsal femoral macroseta; without ventral tibial macrosetae. Very unequal, elbow-like claws with large lateral crests, posterior claw with a large
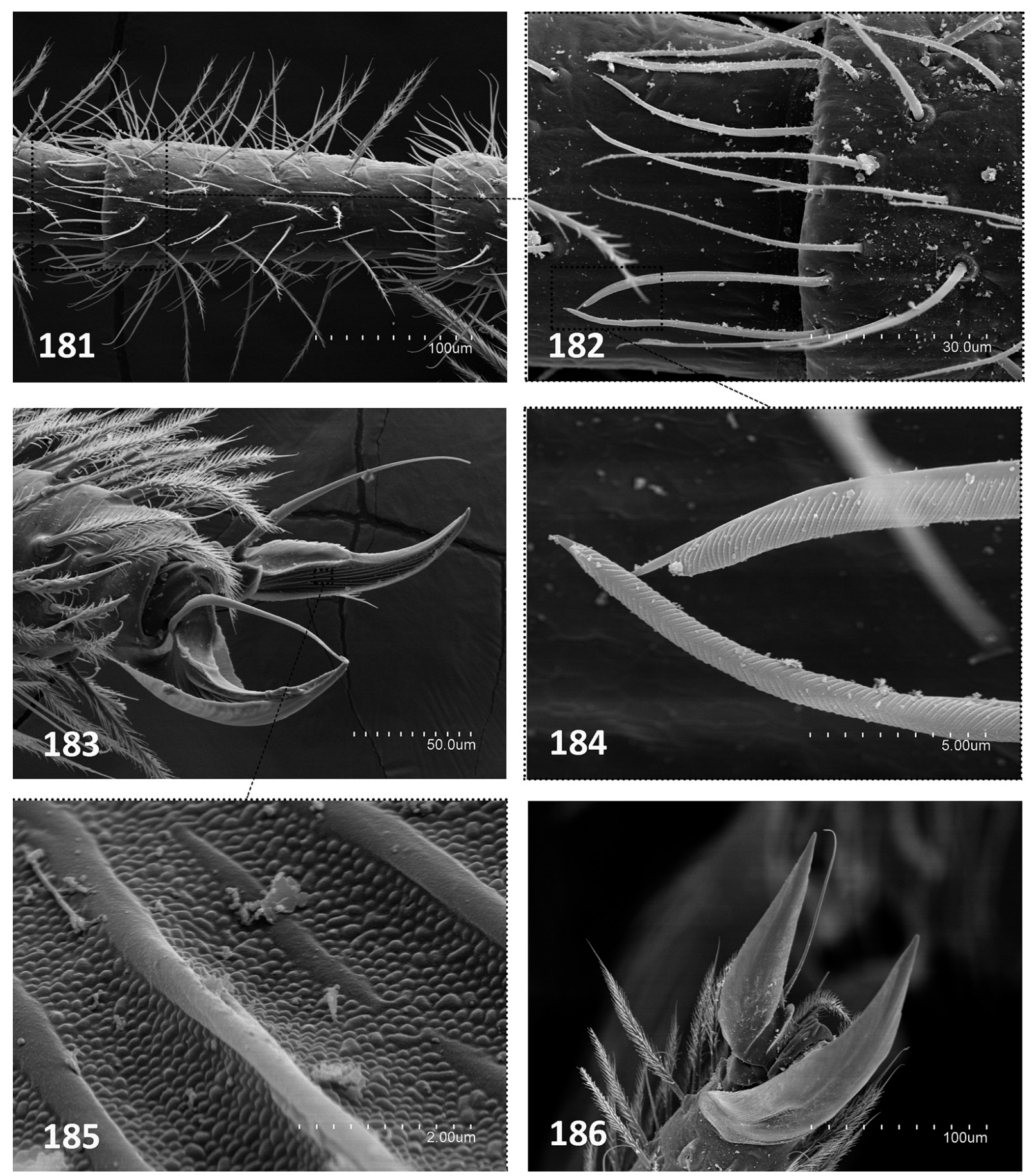

Figs 181-186. Plusiocampa (Stygiocampa) remyi Condé, 1947, from Njegoš pećina, Njeguši, Kotor, Montenegro (Coll. AS). 181. Medial antennomere. 182. Distal portion of a medial antennomere. 183. Pretarsus of a metathoracic leg, lateral view with posterior claw in the foreground. 184. Distal portion of two gouge sensilla. 185. Ventral side of anterior claw, detail. 186. Pretarsus of a metathoracic leg, dorsal side. 
backward overhang. Urotergites with at most $1+1$ lateral anterior and $4+5$ posterior macrosetae starting from sixth urotergite; urosternite I with $7+7$, urosternites II-VII with $5+5$, urosternite VIII with $2+2$ macrosetae. Male with thick, enlarged appendages with a large area of glandular $a_{1}$ setae.
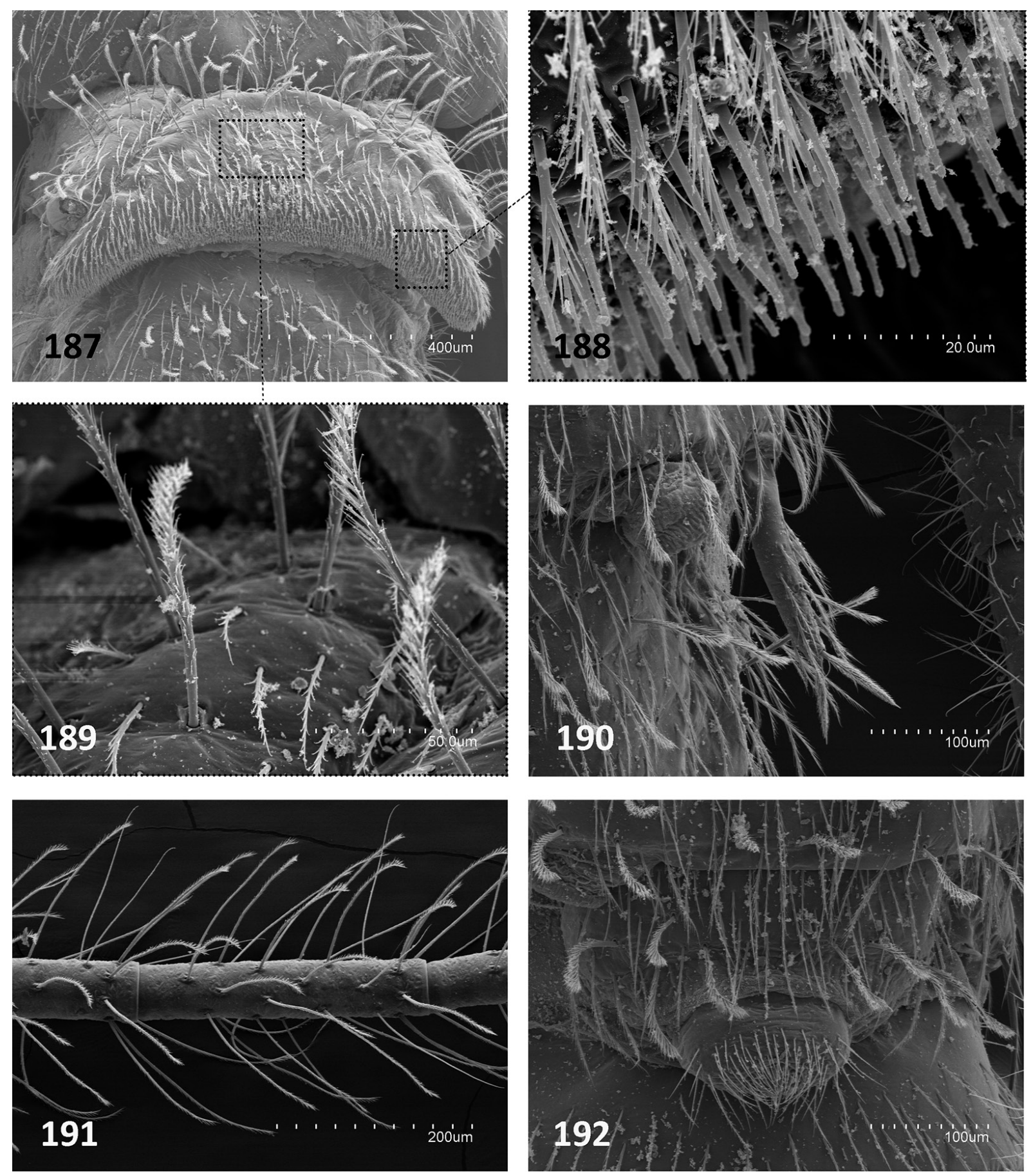

Figs 187-192. Plusiocampa (Stygiocampa) remyi Condé, 1947, from Njegoš pećina, Njeguši, Kotor, Montenegro $(187-190,192)$ and Đatlo pećina, Lebršnik, Gacko, Bosnia and Herzegovina (191) (Coll.

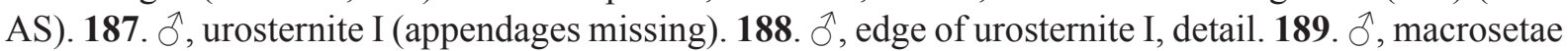
on urosternite I, detail. 190. Lateral posterior view of urosternite V. 191. Second cercal article. 192. $\widehat{\partial}$, urosternite VIII. 


\title{
Habitat and distribution
}

The two species of the subgenus Venetocampa, which inhabit the subterranean habitat, are found in two caves of the Veneto Region, northern Italian Peninsula (Fig. 211).

Plusiocampa (Venetocampa) ferrani Sendra \& Delić sp. nov. urn:1sid:zoobank.org:act:27DC5E1D-B0E4-4BAD-B12E-20ADF1BF16FB

Figs 193-195

\section{Etymology}

This species is named after Milan Ferran, an enthusiastic caver, discoverer and explorer of the type locality in Ferranova buža (meaning Ferran's hole), Slovenia.

\section{Material examined}

\section{Holotype}

SLOVENIA • đ’; Vrhnika, Ferran buža; 16 Feb. 2013; T. Delić, T. Novak and M. Feron leg.; MZB 20191031.

\author{
Paratype \\ SLOVENIA • 1 juv.; same collecting data as for holotype; Coll. AS.
}

\section{Description}

Body. Body length $3.0 \mathrm{~mm}$ (holotype) and $2.8 \mathrm{~mm}$ (paratype). Epicuticle smooth under optical microscope; body with sparse middle-sized clothing setae, distal two-thirds with thin barbs.

Head. Two intact antennae in holotype, slightly longer than body length $(3.5 / 3.6 \mathrm{~mm})$, with $32 / 33$ antennomeres, in paratype slightly shorter than body length $(2.76 / 2.75 \mathrm{~mm})$, with $32 / 32$ antennomeres. Small, subcylindrical sensillum of third antennomere in ventral position between $c$ and $d$ macrosetae; central antennomeres $1.7 \times$ as long as wide, apical antennomere $2.0 \times$ as long as wide; cupuliform organ occupies $1 / 6$ of its length, with 7 or 8 spheroidal olfactory chemoreceptors, each with at least two folds, in cupuliform organ; gouge sensilla starting on ventral side of third antennomere, with an apical row of eight gouge sensilla; fourth antennomere with 12 ventral gouge sensilla and 1 dorsal gouge sensillum; fifth antennomere with 12 ventral and 2 dorsal gouge sensilla; sixth antennomere with 13 ventral and 4 dorsal gouge sensilla; seventh antennomere with 15 ventral and 6 dorsal gouge sensilla; eighth antennomere with 14 ventral and 7 dorsal gouge sensilla; ninth antennomere with 12 ventral and 8 dorsal gouge sensilla; after tenth antennomere a complete apical whorl of gouge sensilla on each antennomere, with about 20 on medial antennomeres and 15 on distal ones. Frontal process with nontubercular macrosetae or setae; macrosetae along line of insertion of antennomere and $x$ setae similar in length, with long, thin distal barbs, on distal two-thirds $(a / i / p / x$ with relative lengths of $33 / 30 / 26 / 39$ in holotype). Small suboval labial palps with a long subcylindrical sensillum, two guard setae, four normal setae and up to 72 neuroglandular setae.

Thorax. Pronotum with $1+1 m a, 2+2 l a_{2,3}, 2+2 l p$ macrosetae; mesonotum with $1+1 m a, 2+2 l a_{2,3}, 2+2$ $l p_{l, 3}$ macrosetae; metanotum with $1+1 m a, 1+1 l a, 2+2 l p_{2,3}$ macrosetae; long notal macrosetae, barbed along distal four-fifths; long marginal setae with barbs along distal two-thirds (Fig. 193). Legs elongated (1.84 $\mathrm{mm}$ long in holotype and $1.54 \mathrm{~mm}$ in paratype), overpassing end of abdomen. Femur with one long dorsal macroseta, barbed almost from its base, inserted around middle of article. No ventral tibial macrosetae. Calcars with 2-3 rows of long barbs from base, with a smooth and narrow lateral side along each calcar. Dorsal and lateral subapical tarsal macrosetae smooth. Very unequal claws, posterior claw 1.6-1.8 $\times$ as long as anterior one, including a large backward overhang on posterior claw; ventral surface 
of claws with grooves, dorsal surface including large lateral crests with thin stripes. Setiform pretarsal processes reaching extremities of claws (Fig. 194).

ABdomen. Distribution of abdominal macrosetae on tergites: $1+1$ (holotype) or $0+0$ (paratype) la, $2+3$ post $_{3,4,5}$ on urotergite VII; $5+5$ post on urotergite VIII; $7+7$ post on abdominal segment IX. All post
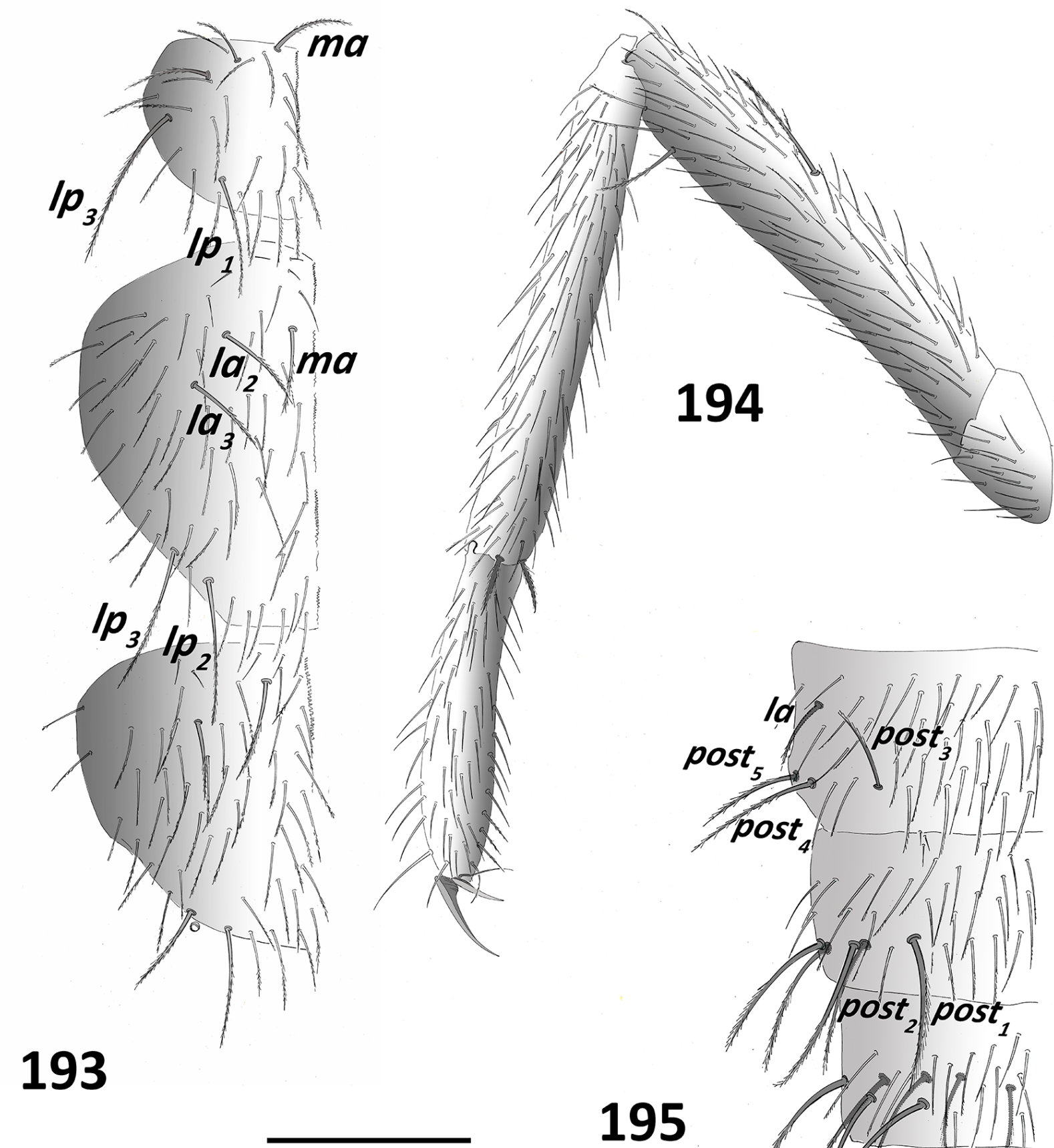

195

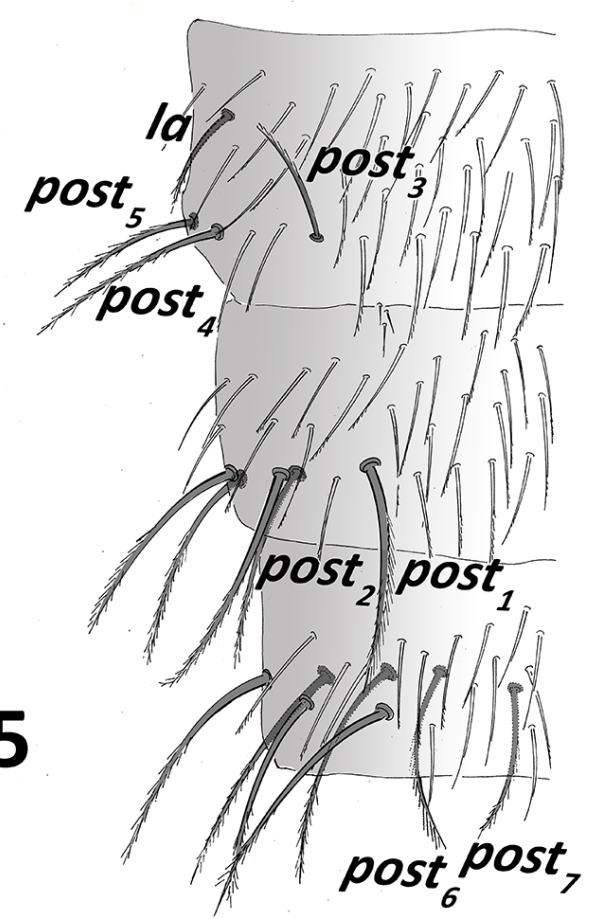

Figs 193-195. Plusiocampa (Venetocampa) ferrani Sendra \& Delić sp. nov., holotype, $\widehat{\partial}$, from Ferranova buža, Vrhnika, Slovenia (MZB 2019-1031). 193. Pronotum, mesonotum and metanotum, left side. 194. Metathoracic leg. 195. Urotergites VII-VIII and abdominal segment IX, right side. Scale bar: $0.2 \mathrm{~mm}$. 
urotergal macrosetae long, robust, barbed on distal four-fifths; la urotergal macrosetae much shorter, barbed along distal half (Fig. 195). Urosternite I with 6+6, urosternites II-VII with 5+5, urosternite VIII with $2+2$ macrosetae; all urosternal macrosetae robust, covered by very long barbs along distal half to three-fourths. Pseudoarticulated stylus with barbed setae with long barbs, apical setae shorter than medial and subapical setae.

SECONDARY SEX CHARACTERS. Male urosternite I without glandular $g_{l}$ setae, subcylindrical short, enlarged appendages with up to 21 large glandular $a_{l}$ setae. Adult female unknown.

\section{Phyletic affinities, habitat and distribution}

Plusiocampa $(V$. $)$ ferrani sp. nov. is the second representative of the subgenus Venetocampa. It is a cavedwelling species closely related to $P$. $(V$.) paoletii, found in the vinicity of Belluno, Italian Alps (Bareth \& Condé 1984). Nonetheless, the macrosetal distribution patterns on the nota and urotergites show enough differences to describe these specimens as a new taxon.

\section{Plusiocampa (Venetocampa) paolettii Bareth \& Condé, 1984}

Plusiocampa paolettii Bareth \& Condé, 1984: 143, figs 5-6.

\section{Diagnosis (Bareth \& Condé 1984)}

Troglomorphic species. Antennae with 33 antennomeres; eight to nine simple olfactory chemoreceptors in perhaps a regenerated antennae; non-tubercular setae in frontal process. Pronotum with $1+1 \mathrm{ma}, 2+2$ $l a, 2+2 l p$ macrosetae; mesonotum with $1+1 m a, 2+2 l a, 2+2 l p$ macrosetae; metanotum with $1+1 m a$, 1+1 lp macrosetae; long, barbed notal macrosetae; abundant notal clothing setae. One dorsal femoral macroseta; no ventral tibial macrosetae; very unequal claws (2.5), posterior claw with a backward overhang, with large lateral crests; short anterior lateral process and long posterior lateral process. Urotergite $\mathrm{V}$ with $0+1$ la macrosetae; urotergite VI with $1+1$ la, 2+2 post macrosetae; urotergite VII with $1+1$ la $1+1$ post macrosetae; urotergite VIII with $4+5$ post macrosetae; abdominal segment IX with $7+7$ post macrosetae; urosternite I with $7+7$, urosternites II-VII with $5+5$, urosternite VIII with $2+2$ macrosetae. Male without glandular $g_{l}$ setae, short and very thick appendages with abundant glandular $a_{1}$ setae; female unknown.

\section{Habitat and distribution}

Subterranean species found in Biga de le Agnelezze Cave, Piani Eterni, Belluno, Italian Alps.

\section{Genus Vandelicampa Condé, 1955}

Vandelicampa Condé, 1955c: 407.

\section{Diagnosis (Condé 1955c)}

Monotypic genus with $1+1$ medial anterior, $(2+2) 3+3$ lateral anterior, $1+1$ medial posterior and $2+2$ lateral posterior macrosetae on mesonotum and with $1+1$ medial anterior, $1+1(2+2)$ lateral anterior, $1+1$ lateral posterior and $2+2$ lateral posterior macrosetae on metanotum. One dorsal femoral macroseta. Two or three ventral tibial macrosetae. Subequal, elbow-like claws with large lateral crests. Laminar pretarsal process with a sharp ending covered with long ventral barbs. Urosternite I with $8+8$, urosternites IIVII with $6+6$, urosternite VIII with $2+2$ macrosetae. Male without glandular $g_{I}$ setae, subcylindrical appendages without glandular $a_{2}$ setae. 
SENDRA A. et al., Euro-Mediterranean Plusiocampinae and tachycampoid diplurans

Vandelicampa tisserandi Condé, 1955

Vandelicampa tisserandi Condé, 1955c: 407, figs 3-4.

Diagnosis (Condé 1955c)

Troglomorphic species. Antennae with 29-38 antennomeres; eight to ten olfactory chemoreceptors in cupuliform organ. Long, barbed notal macrosetae; sparse, smooth, long notal clothing setae. One dorsal femoral macroseta; two or three ventral tibial macrosetae; subequal claws (1.04) with large lateral crests, posterior claw without a backward overhang; laminar pretarsus processess with a sharp ending covered with long ventral barbs. Urotergites I-III with $1+1$ post macrosetae; urotergite IV with $1+1$ la, $3+3$ post macrosetae; urotergites V-VII with $3+3(2+2)$ la, 4+4 post macrosetae; urotergite VIII with $6+6$ post macrosetae; urosternite I with $8+8$, urosternites II-VII with $6+6$, urosternite VIII with $2+2$ macrosetae. Male with subcylindrical appendages of first urosternite similar to those of female.

\section{Habitat and distribution}

Subterranean species found in three caves in the karst areas of Lebanon (Fig. 210).

\section{Tachycampoid phyletic lineage}

\section{Other genera related to Plusiocampinae, the tachycampoid phyletic lineage}

Bareth \& Condé (1981) originally proposed a unique and different tachycampoid phylogenetic lineage ("lignée Tachycampoïde") for a number of previously described genera: Tachycampa Silvestri, 1936 with one species from a cave in the western Rif Mountains (Silvestri 1936); Paratachycampa Wygodzinsky, 1944 with three species, one from a cave in Nuevo León (Mexico) and two from several caves in the eastern Iberian Peninsula (Wygodzinsky 1944; Bareth \& Condé 1981); Juxtlacampa Wygodzinsky, 1944 with two species, one from a cave in Guerrero (Mexico) and another from a cave in Alta Verapaz (Guatemala) (Wygodzinsky 1944); and Jeannelicampa Condé, 1955 with one species from caves in Tell Atlas (Algeria) (Condé 1952, 1954c). Much later, Condé (1982) proposed a new genus within this phyletic lineage, Oncinocampa Condé, 1982, for a subterranean species from the north of the Iberian Peninsula and another one from Sardinia (Condé 1981b, 1982). A few years later, the diversity of Oncinocampa was increased with four more species, two from the same karst region in the Cantabric Mountain Range on the northern Iberian Peninsula (Sendra \& Condé 1988, Bareth 1989) and two from caves in the Americas, one near São Paulo, Brazil (Condé 1997) and another in Veracruz, Mexico (Sendra et al., 2016). The number of species in Tachycampa has also been expanded with three new cave-dwelling species from Mexico (Sendra et al. 2016) (Fig. 209).

Diagnosis (Bareth \& Condé 1981; Sendra et al. 2016)

Three main morphological features support the phyletic line of the tachycampoid group, although exceptions exist. First, the elbow-like claws with lateral crests (absent in Jeannelicampa stygia Condé, 1952). Second, the notal macrosetal formula: pronotum with $3+3 m a$, $l a$ and $l p$; mesontum with $2+2 m a$ and $l a$; metanotum with $1+1 m a$ or fewer (with only $1+1 l p$ pronotal macrosetae in Oncinocampa genuitei (Bareth, 1989); Paratachycampa hispanica Bareth \& Condé, 1981 and P. penyoensis Bareth \& Condé, 1981 have an extra lateral anterior macroseta). Finally, dorsal macrosetae are absent from the femur, with the exception of a small, thin macroseta in $O$. asonensis Sendra \& Condé, 1988 and $O$. paclti Condé, 1981. Additionally, all species inhabit subterranean ecosystems, except $O$. paclti, which has non-troglomorphic features.

\section{Taxonomic key to Euro-Mediterranean tachycampoid genera and species}

1. $2+2$ macrosetae on urosternite VIII .2

- 1+1 macrosetae on urosternite VIII 
2. 9+9 macrosetae on urosternites II-VII ..........Paratachycampa penyoensis Bareth \& Condé, 1981

- $6+6$ or $7+7$ macrosetae on urosternites II-VII

3. $6+6$ macrosetae on urosternites II-VII

Jeannelicampa stygia Condé, 1952

- $7+7$ macrosetae on urosternites II-VII Paratachycampa hispanica Bareth \& Condé, 1981

4. Pretarsal claws without lateral crests Jeannelicampa stygia Condé, 1952

- Pretarsal claws with lateral crests .5

5. Pretarsal claws with large lateral crests, but without backward overhang

Tachycampa lepineyi Silvestri, 1936

- Pretarsal claws with small lateral crests .6

6. Appendages of urosternite I in adult males piriform or subtrapezoidal ......................................

- Appendages of urosternite I in adult males short, thick and large ...............................................8

7. Appendages of urosternite I in adult males piriform

Oncinocampa asonensis Sendra \& Condé, 1988

- Appendages of urosternite I in adult males subtrapezoidal ......Oncinocampa paclti (Condé, 1981)

8. 1+1 lateral anterior macrosetae or submacrosetae on pronotum, mesonotum and metanotum; $1+1$ lateral anterior pronotal macrosetae or submacrosetae Oncinocampa falcifer Condé, 1982

- Without notal macrosetae, except 1+1 long lateral posterior pronotal macrosetae

Oncinocampa genuitei Bareth, 1989

Genus Jeannelicampa Condé, 1952

Jeannelicampa Condé, 1952: 64.

Diagnosis (Condé 1952, 1954c)

Pronotum with $3+3$ medial anterior, lateral anterior and lateral posterior macrosetae; mesonotum with $1+1$ medial anterior macrosetae and with or without $1+1$ lateral anterior submacrosetae; metanotum with or without $1+1$ medial anterior submacrosetae. No dorsal femoral macrosetae; one ventral tibial macroseta. Simple and slightly curved claws with smooth, laminar lateral process. Urotergal macrosetae start from urotergite V or VII. 9+9 macrosetae on first urosternite. Male unknown.

Jeannelicampa stygia Condé, 1952

Jeannelicampa stygia Condé, 1952: 65, fig. 2.

Diagnosis (Condé 1952, 1954c)

Troglomorphic species. Antennae with 40-48 antennomeres; 20-28 olfactory chemoreceptors in cupuliform organ; protruding frontal process with non-tubercular setae. Pronotum with $1+1 m a, 1+1$ $l a, 1+1$ lp macrosetae; mesonotum with $1+1$ short $m a$ macrosetae and $0+0-1+1$ sla submacrosetae; metanotum with $0+0-1+1$ sma submacrosetae; long, barbed pronotal macrosetae, short mesonotal macrosetae; clothing setae barbed along distal three-fourths. No dorsal femoral macrosetae; one ventral tibial macroseta; subequal, slightly curved claws without lateral crests; narrow, laminar, smooth pretarsal processes. Urotergites V-VII with $0+0-1+1$ la macrosetae; urotergite VIII with $2+2-3+3(2+1)$ post macrosetae; urosternite I with $9+9$, urosternites II-VII with $6+6$, urosternite VIII with $1+1-2+2$ macrosetae. Female appendages of urosternite I subcylindrical, with glandular $a_{1}$ setae; male unknown. 


\section{Habitat and distribution}

Subterranean species located in two caves: Bou Iacor and Misserghin Ravine in Oran, Tell Atlas, Algeria (Fig. 210).

Genus Oncinocampa Condé, 1982

Oncinocampa Condé, 1982: 71.

Diagnosis (Sendra \& Condé 1988; Condé 1997; Sendra et al. 2016)

Pronotum with $3+3$ medial anterior, lateral anterior and lateral posterior macrosetae; mesonotum with $2+2$ medial anterior and lateral anterior macrosetae; metanotum with $1+1$ medial anterior macrosetae. Dorsal femoral macrosetae absent (with the exception of $O$. asonensis and $O$. paclti); ventral tibial macrosetae absent (exceptions: one in $O$. paclti and O. trajanoae Condé, 1997); elbow-like claws with small lateral crest, without a backward overhang; setiform, smooth lateral process; one pair of lateral anterior and lateral posterior urotergal macrosetae on medial urotergites (absent in $O$. bolivarurrutiai Sendra \& García, 2016); apical, subapical and medial setae of stylus with a few small barbs.

\section{Habitat and distribution}

The six current species of this genus have been found in caves, although two are non-troglomorphic. They have an amphi-Atlantic distribution, with one species in Mexico, one in Brazil, three in the center of the Cantabrian Mountain Range on the Iberian Peninsula and one in Sardinia (Fig. 210).

Oncinocampa asonensis Sendra \& Condé, 1988

Oncinocampa asonensis Sendra \& Condé, 1988: 1019, figs 1-4, table 1.

Diagnosis (Sendra \& Condé 1988)

Troglomorphic species. Epicuticle smooth under optical microscope. Antennae with 53-64 antennomeres; protruding frontal process with non-tubercular setae; nine or ten complex olfactory chemoreceptors. Pronotum with 1+1 ma, 1+1 la, 1+1 lp macrosetae; mesonotum with 1+1 ma, 1+1 la macrosetae; metanotum with 1+1 ma macrosetae; long, barbed notal macrosetae; smooth, long clothing setae. Dorsal femoral macrosetae absent; ventral tibial macrosetae absent; subequal, elbow-like claws with small lateral crests; setiform, smooth pretarsal processes. Urotergites V-VII with $1+1$ la, $1+1$ lp macrosetae; urotergite VIII with $4+4$ post macrosetae; abdominal segment IX with $6+6$ post macrosetae; urosternite I with 7+1+7-11+1+11, urosternites II-VII with 6+6-7+7 (6+9), urosternite VIII with $1+1$ macrosetae. Male with remarkable large lateral expansion on posterior border with glandular $g_{1}$ setae; piriform appendages with glandular $a_{1}$ and $a_{2}$ setae; subcylindrical appendages with glandular $a_{1}$ and $a_{2}$ setae.

\section{Habitat and distribution}

Subterranean species found in seven caves in the karst areas around Ason Valley, in the CantabroBasque sector of the Cantabric Mountain Range, northern Iberian Peninsula.

Oncinocampa falcifer Condé, 1982

Oncinocampa falcifer Condé, 1982: 71, figs 1-2.

Diagnosis (Condé 1982)

Troglomorphic species. Epicuticle smooth under optical microscope. Antennae with 39-40 antennomeres; six complex olfactory chemoreceptors in cupuliform organ; non-tubercular frontal process setae. 
Pronotum with $1+1 \mathrm{ma}, 1+1$ la, $1+1$ lp macrosetae; mesonotum with $1+1 \mathrm{ma}, 1+1$ la macrosetae; metanotum with 1+1 ma macrosetae; long, thin macrosetae with a few barbs; short, smooth clothing setae. One weak dorsal femoral macroseta; ventral tibial macrosetae absent; unequal, elbow-like claws with very small lateral crests; setiform, smooth pretarsal process. Urotergites VI-VII with $1+1 l a, 1+1$ lp macrosetae; urotergite VIII with $3+3$ post macrosetae; abdominal segment IX with $5+5$ post macrosetae; urosternite I with 7+7, urosternites II-VII with 4+4, urosternite VIII with 1+1 macrosetae. Male without glandular $g_{1}$ setae; short, thick and enlarged appendages with glandular $a_{1}$ and $a_{2}$ setae; female unknown.

Oncinocampa aff. falcifer Condé, 1982

\section{Differential diagnosis against the type form}

Two specimens (Coll. AS), in poor condition and difficult to observe under the microscope, were collected in two adjacent caves, Sima de Landubia and Sistema de la Cubada Grande (Burgos) in the southeast of the Cantabrian Mountain Range. Mesonotum and metanotum with $l p$ macrosetae, in addition to some variation in urotergal macrosetae. Nevertheless, new specimens should be collected before establishing a new species.

\section{Habitat and distribution}

Subterranean species known only from Cueva de la Marniosa (Treviso, Cantabria), Picos de Europa, Central Cantabrian Mountain Range. The aff. form was found in two caves in the southeast of the Cantabrian Mountains, northern Iberian Peninsula.

Oncinocampa genuitei Bareth, 1989

Oncinocampa genuitei Bareth, 1989: 131, fig. 1.

\section{Diagnosis (Bareth 1989)}

Troglomorphic species. Epicuticle smooth under optical microscope. Non-protruding frontal process, non-tubercular setae. Pronotum with $1+1 \mathrm{lp}$ macrosetae, long and poorly barbed; mesonotum and metanotum without macrosetae; smooth, short notal clothing setae. No dorsal femoral macrosetae; ventral tibial macrosetae absent; without developed calcars; very unequal, elbow-like claws with small lateral crests; setiform, smooth pretarsal process. Urotergite IV with $1+1 \mathrm{lp}$ macrosetae; urotergites VVII with $1+1$ la and $1+1$ lp macrosetae; urotergite VIII with $3+3$ post macrosetae; abdominal segment IX with $6+6$ post macrosetae; urosternite I with $7+7$, urosternites II-VII with $4+4$, urosternite VIII with $1+1$ macrosetae. Male without glandular $g_{1}$ setae; short, thick, enlarged appendages with glandular $a_{1}$ and $a_{2}$ setae; female unknown.

\section{Habitat and distribution}

Subterranean species known only from Sima del Trave, collected at a depth of 550 meters, Picos de Europa, Central Cantabrian Mountain Range, northern Iberian Peninsula.

\section{Oncinocampa paclti (Condé, 1981)}

Litocampa paclti Condé, 1981a: 96, fig. 1.

Plusiocampa (Stygiocampa) sp. - Paclt 1979: 222.

Diagnosis (Paclt 1979; Condé 1981a; Sendra \& Condé 1988)

Non-troglomorphic species; epicuticle with microdenticles; antennae with 18-25 doliiform antennomeres; gouge sensilla thick and short; four to six simple olfactory chemoreceptors in cupuliform 
organ; non-developed frontal process, with non-tubercular setae. Pronotum with $1+1 \mathrm{ma}, 1+1 \mathrm{la}, 1+1 \mathrm{lp}$ macrosetae; mesonotum with 1+1 ma, 1+1 la macrosetae; metanotum with 1+1 ma macrosetae; middlesized notal macrosetae with a few distal long barbs, la pronotal and $m a$ macrosetae with one or two distal barbs; short, smooth clothing setae. No dorsal femoral macrosetae; one ventral tibial macroseta; small, subequal, elbow-like claws with very small lateral crests; setiform, smooth pretarsal processes. Urotergites I-IV with 1+1 ma macrosetrae; urotergites V-VII with 1+1 ma, 1+1 la, 1+1 lp macrosetae; urotergite VIII with $1+1 \mathrm{ma}, 3+3$ post macrosetae; abdominal segment IX with $1+1 \mathrm{ma}, 5+5$ post macrosetae; urosternite I with $6+6$, urosternites II-VII with $4+4$, urosternite VIII with $1+1$ macrosetae; male with glandular $g_{1}$ setae; small, subtrapezoidal appendages with glandular $a_{1}$ and $a_{2}$ setae; female with subcylindric appendages with glandular $a_{l}$ setae.

\section{Habitat and distribution}

Non-troglomorphic species found in one cave and within soil at two adjacent localities in the east of Sardinia.

Genus Paratachycampa Wygodzinsky, 1944

Paratachycampa Wygodzinsky, 1944: 371.

Diagnosis (Wygodzinsky 1944; Bareth \& Condé 1981)

Pronotum with 1+1 ma, 1+1-2+2 la, 1+1 lp macrosetae; mesonotum with $1+1 \mathrm{mp}, 1+1$ la macrosetae; metanotum with 1+1 ma macrosetae. Dorsal femoral macrosetae absent; ventral tibial macrosetae absent. Claws with lateral crest, with a backward overhang. Pretarsal lateral processes from setiform to laminar and well barbed on ventral side. Urotergal macrosetae start on urotergite III or IV. Stylus with pubescent apical, subapical and medial setae. Extra urosternal macrosetae on first urosternite and $2+2$ on eighth urosternite. Male with elongate appendages, covered with a large area of glandular $a_{2}$ setae.

\section{Habitat and distribution}

All three known species are highly cave-adapted to the deep subterranean ecosystems. The genus Paratachycampa has an amphi-Atlantic distribution, with one species in Mexico and two on the Iberian Peninsula (Fig. 210).

Paratachycampa hispanica Bareth \& Condé, 1981

Figs 196-201, 206

Paratachycampa hispanica Bareth \& Condé, 1981: 776, figs 1a-c, 2a-c, 3a-c, 4a-c, 5a, c, e.

Diagnosis (Bareth \& Condé 1981; Sendra 1988; Sendra \& Escolà 2004)

Troglomorphic species. Epicuticle smooth. Antennae with 34-40 elongated antennomeres; 12-16 complex olfactory chemoreceptors in cupuliform organ. Protruding frontal process with abundant tubercular setae. Pronotum with $1+1 m a, 2+2 l a, 1+1 l p$ macrosetae; mesonotum with $1+1 m a, 1+1 l a$ macrosetae; metanotum with $1+1 \mathrm{ma}, 1+1$ la macrosetae; long, thin notal macrosetae with a very few barbs; long, thin smooth clothing setae. Subequal, elbow-like claws with large lateral crests, posterior claw with a backward overhang; laminar, barbed ventral pretarsal processes. Urotergites III-VII with 1+1 la macrosetae; urotergite VIII with $4+4$ post macrosetae; abdominal segment IX with 7+7 post macrosetae; urosternite I with $22+22$, urosternites II-VII with 7+7, urosternite VIII with 2+2 macrosetae. Male without glandular $g_{1}$ setae; overdeveloped appendages with a large area of glandular $a_{2}$ setae and an apical area of glandular $a_{1}$ setae; subcylindrical female appendages with glandular $a_{1}$ and $a_{2}$ setae. 


\section{Remarks}

The studied material (see Table S2 in Supplementary Material) allowed us to add taxonomic details revealed by SEM microscopy. Gouge sensilla abundant, as long as $28 \mu \mathrm{m}$, with thick transversal stripes with alternating rows of pores between them (Figs 196-197). Subequal claws with well-developed
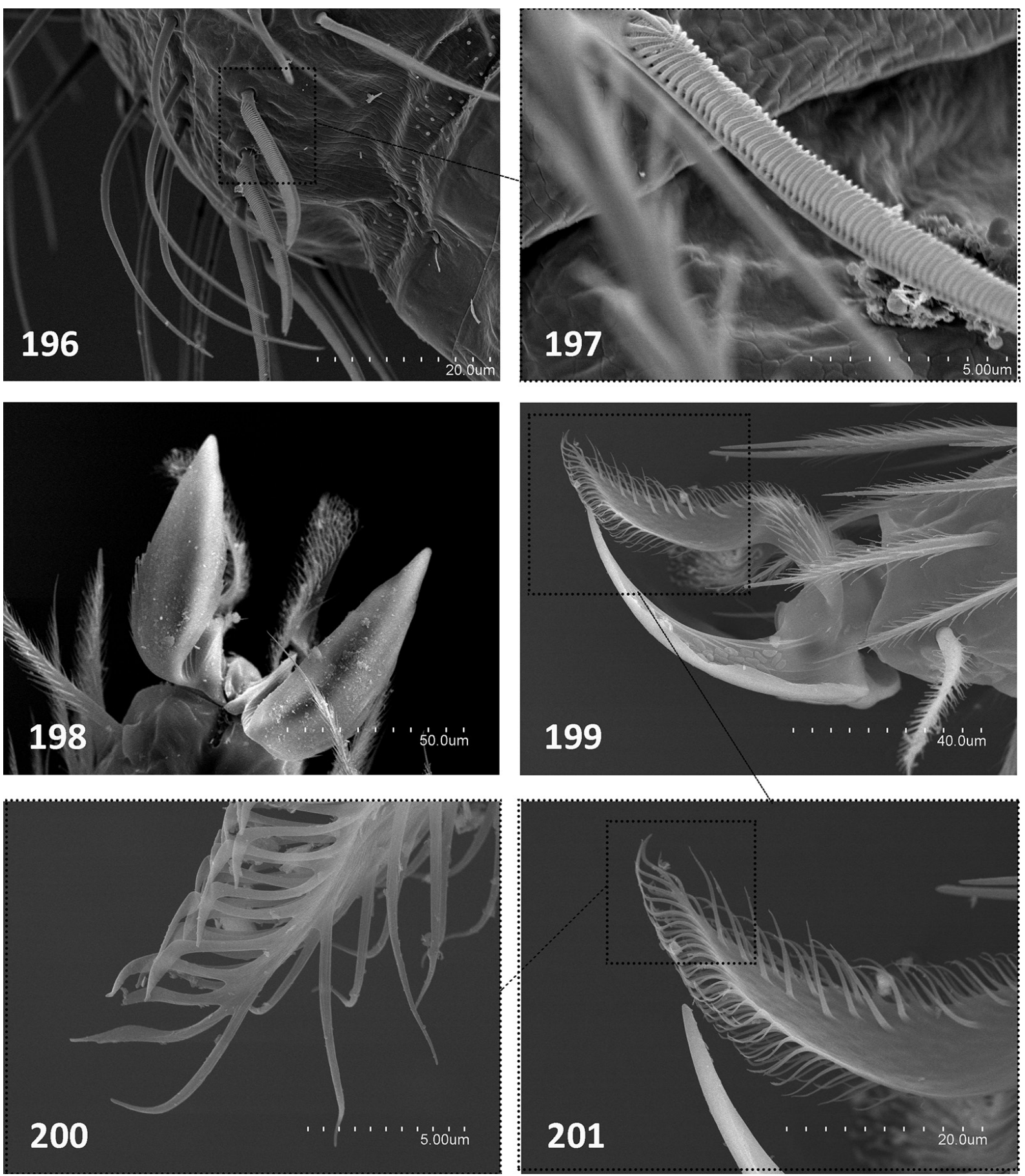

Figs 196-201. Paratachycampa hispanica Bareth \& Condé, 1981, from Cova dels Encenalls, Sant Mateu, Spain (Coll. AS). 196. Lateral distal view of a medial antennomere with gouge sensilla. 197. Basal view of a gouge sensillum. 198. Pretarsus of a metathoracic leg. 199. Lateral view of pretarsus, metathoracic leg. 200. Distal part of lateral process of pretarsus, metathoracic leg. 201. Apical part of lateral process of pretarsus, metathoracic leg. 
SENDRA A. et al., Euro-Mediterranean Plusiocampinae and tachycampoid diplurans

lateral crests (Figs 198-199). Lateral processes of pretarsus with S-shape, its ventral side covered with long, hooked barbs (Figs 200-201).

\section{Habitat and distribution}

Subterranean species found in nine caves throughout the coastal karst reliefs in the east of the Iberian Peninsula (Fig. 206).

Paratachycampa penyoensis Bareth \& Condé, 1981

Paratachycampa peynoensis Bareth \& Condé, 1981: 780, figs 1d, 2d, 3d, 4d-e, 5b, d, f [corrected here to penyoensis].

Diagnosis (Bareth \& Condé 1981; Sendra 1988)

Troglomorphic species. Epicuticle smooth under optical microscope. Antennae with 30-38 elongated antennomeres. Protruding frontal process well developed, with tuberculated, barbed setae. Pronotum with $1+1 m a, 2+2 l a, 1+1$ lp macrosetae; mesonotum with $1+m a, 1+1$ la macrosetae; metanotum with 1+1 ma macrosetae; middle-sized, barbed notal macrosetae; short, barbed clothing setae. Subequal, elbow-like claws with large lateral crests, with backward overhang; laminar, barbed ventral pretarsal processes. Urotergites III-V with $1+1$ la macrosetae; urotergite VI with $1+1$ la, $1+1-2+1$ lp macrosetae; urotergite VII with $1+1 l a, 2+2-3+4$ lp macrosetae; urotergite VIII with 4+4-6+6 post macrosetae; abdominal segment IX with $6+6-7+7$ post macrosetae; urosternite I with $21+21-22+22$, urosternites IIVII with 5+5, urosternite VIII with $2+2$ macrosetae. Male without glandular $g_{l}$ setae; developed, large appendages with a large area of glandular $a_{2}$ setae and an apical area of glandular $a_{1}$ setae; subcylindrical female appendages with glandular $a_{1}$ and $a_{2}$ setae.

\section{Habitat and distribution}

Subterranean species found in two caves, Cova del Penyó (type locality) and the Soterranya Cave (Serra, València), Calderona Massif, eastern Iberian Peninsula.

Genus Tachycampa Silvestri, 1936

Tachycampa Silvestri, 1936: 86.

Diagnosis (Sivestri 1936; Sendra et al. 2016)

Epicuticle with microdenticles on surface. Pronotum with $3+3$ medial anterior and lateral posterior macrosetae, and lateral anterior submacrosetae; mesonotum with $2+2$ medial and lateral anterior submacrosetae; metanotum with 1+1 medial anterior submacrosetae. Dorsal femoral macrosetae absent. One small ventral tibial macroseta. Subequal, elbow-like claws with large lateral crests, posterior claw without a backward overhang; setiform, smooth pretarsal processes. With $3+3$ and $6+6$ posterior macrosetae on urotergite VIII and abdominal segment IX, respectively; urosternite I with $8+8-11+11$, urosternites II-VII with $8+8$, urosternite VIII with $1+1$ macrosetae. Male urosternite I with glandular $g_{1}$ setae; short, thick, large appendages with a large area of glandular $a_{1}$ and $a_{2}$ setae; female with subcylindrical appendages with glandular $a_{1}$ setae.

\section{Habitat and distribution}

The four species of this genus are found in subterranean habitats, in the deep areas of caves. It has an amphi-Atlantic distribution, with three species in Mesoamerica and another one in the Rif Mountains, northwestern Africa (Fig. 210). 
Tachycampa lepineyi Silvestri, 1936

Tachycampa lepineyi Silvestri, 1936: 86, figs 1-11.

Diagnosis (Sivestri 1936; Condé 1952)

Troglomorphic species. Epicuticle with microdenticles. Antennae with 36-38 antennomeres; about 20 small complex olfactory chemoreceptors in cupuliform organ; protruding frontal process, with nontubercular setae. Pronotum with $1+1 \mathrm{ma}$ and $1+1 \mathrm{lp}$ macrosetae and 1+1 sla submacrosetae; mesonotum with 1+1 sma and 1+1 sla submacrosetae; metanotum with 1+1 sma submacrosetae; short, smooth notal macrosetae; short, smooth notal clothing setae. Dorsal femoral macrosetae absent; one small ventral tibial macroseta; subequal, elbow-like claws with large lateral crests, posterior claw without a backward overhang; setiform pretarsal processes. Urotergite VIII with $3+3$ post macrosetae; abdominal segment IX with $6+6$ post macrosetae; urosternite I with $8+8-11+11$, urosternites II-VII with $8+8$, urosternite VIII with $1+1$ macrosetae. Male urosternite I with a wide area of glandular $g_{l}$ setae; short, thick, large appendages with a large area of glandular $a_{1}$ and $a_{2}$ setae; female with enlarged subcylindrical appendages with glandular $a_{1}$ setae.

\section{Remarks}

The study of many specimens collected from five new caves (Coll. AS) (see Table S2 in Supplementary Material) allowed the addition of information to the diagnosis and the inclusion of other minor taxonomic characters: ventral sensillum in third antennomere; labial palps with thick sensilla, two guard sensilla, nine simple setae and about 80 neuroglandular setae; metathoracic leg reaching end of abdomen; calcars with long barbs running up from base in two rows; smooth subapical tarsal setae; stylar setae covered with a few long barbs, apical setae with large basal tooth.

\section{Habitat and distribution}

Subterranean species found in nine caves in the karst areas near Taza in the Middle Atlas Mountains, Morocco.

\section{Discussion}

\section{Species diversity, phylogenetic groupings and distribution}

The systematic groups are here maintained as those previously suggested for Campodeidae (Silvestri 1912; Condé 1955a; Paclt 1957; Bareth \& Condé 1981, 1984; Condé \& Bareth 1996; Sendra et al. 2016, 2017a, 2018; Sendra \& Weber 2018). Using morphological characters, a phylogenetic grouping seems natural for the five subfamilies of Campodeidae (Paclt 1957) plus the tachycampoid phyletic lineage proposed by Bareth \& Condé (1981). Nevertheless, not all genera and subgenera seem monophyletic within Plusiocampinae and the tachycampoids. This is the case for the Asian and African species of Plusiocampinae (Condé 1993b; Sendra et al. 2012a, 2017a). However, the European and Mediterranean genera of Plusiocampinae and tachycampoids belong to two well-differentiated phyletic lineages with a distinct biogeographical pattern. The five Euro-Mediterranean genera of Plusiocampinae (Cestocampa, Hystrichocampa, Patrizicampa, Plusiocampa and Vandelicampa) share remarkable morphological characters: 1) the ventral position of the sensillum on the third antennomere; 2) the pattern of macrosetal distribution on the pronotum, with two pairs of lateral posterior macrosetae; 3) the elbow-like claws with lateral crests; and 4) two pairs of macrosetae on the eighth urosternite. They also have some taxonomically less important similarities, such as a smooth cuticle as seen in an optical microscope (cuticle often appears reticulated in SEM) and the absence of pores on the dorsal sclerites. For the tachycampoid lineage, the four studied genera (Jeannelicampa, Oncinocampa, Paratachycampa and Tachycampa) show notable differences in several morphological characters, for instance the simple claws in J. stygia or the presence of medial anterior macrosetae on the urotergites in O. paclti (Figs 209-210). 
SENDRA A. et al., Euro-Mediterranean Plusiocampinae and tachycampoid diplurans
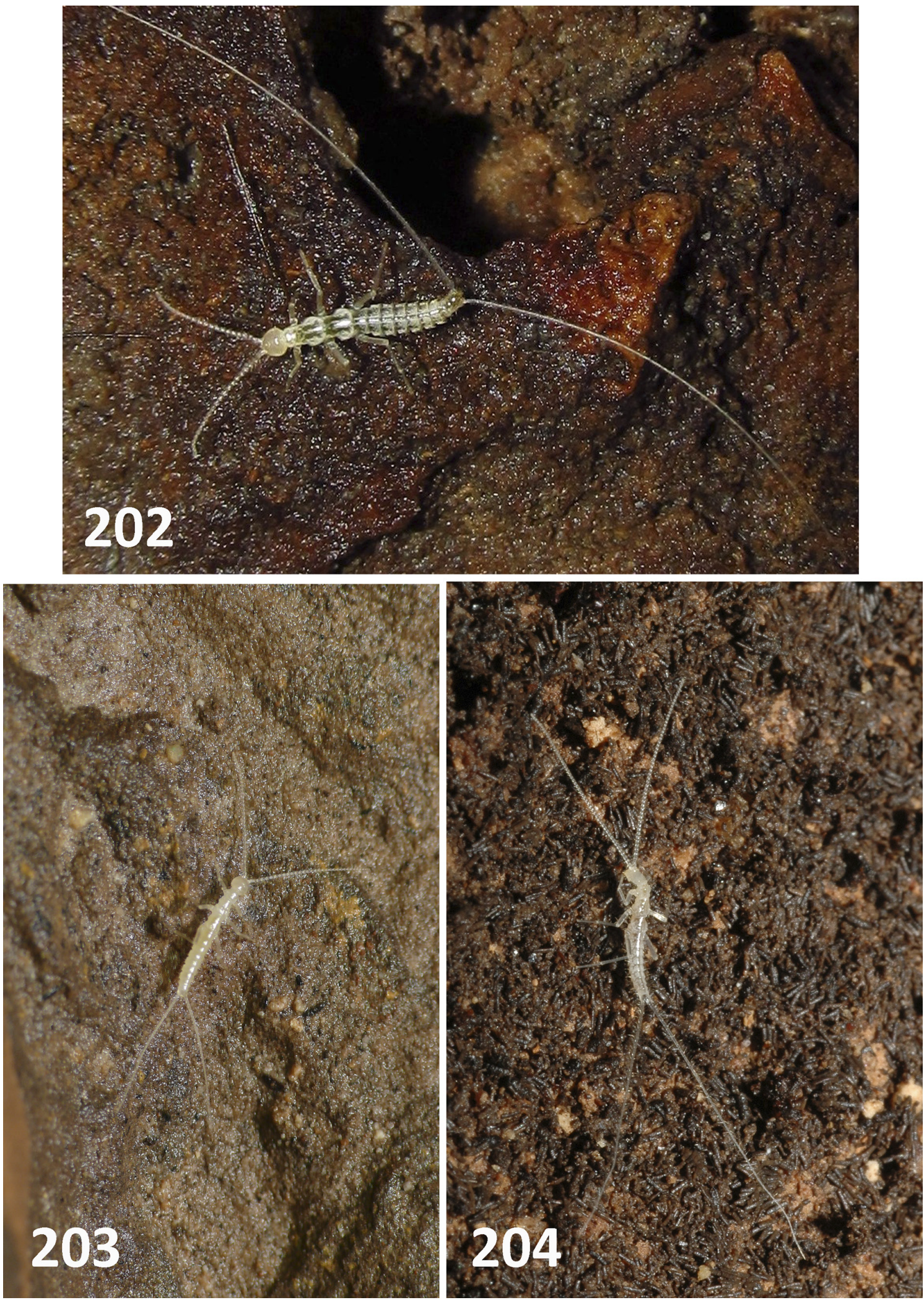

Figs 202-204. 202. Plusiocampa (Stygiocampa) christiani Condé \& Bareth, 1996, from Lazareva Cave, Serbia (photo: Dragan Antić). 203. Plusiocampa (Plusiocampa) lagari Sendra \& Condé, 1987, from Chorros Cave, Albacete, Spain (photo: Toni Pérez). 204. Plusiocampa (Plusiocampa) hoffmanni Sendra \& Paragamian sp. nov., from Splialio Sfentone Trypa Cave, Crete (photo: Kaloust Paragamian). 
The Euro-Mediterranean Plusiocampinae represent the vast majority of the entire subfamily, with 78 species out of the total 91 species around the world. Plusiocampa is the most diverse genus of Plusiocampinae, with 71 species and 10 subspecies from the Euro-Mediterranean region (Table 13, Fig. 211; see also Table S1 in Supplementary Material). The remaining genera are far less diversified: Cestocampa includes four species, while Hystrichocampa, Patrizicampa and Vandelicampa are monotypic (Fig. 210). This biodiversity estimate does not consider the Asian species of Plusiocampa and Cestocampa, proposed to be placed in new genera by Sendra et al. (2012a, 2017a). The European region appears to be the center of origin for Plusiocampinae, but new evidence of undescribed taxa from East Asia has emerged (Sendra, unpubl. data), suggesting Asia as the most likely center of origin. Nonetheless, more sampling efforts and studies in Central and East Asia are required to reach a clearer view of the origin and possible colonization scenario for this subfamily, highly diversified in subterranean ecosystems.

The evolutionary relationships among taxa are not clear within the Euro-Mediterranean Plusiocampinae. Cestocampa, Patrizicampa and Vandelicampa are split from Plusiocampa by a single character: the laminar processes of the pretarsus are covered by pubescence instead of being smooth and setiform, as in species of Plusiocampa. Hystrichocampa is separated by the unique pubescent, thick setiform lateral processes of the pretarsus. The subgenera of Plusiocampa are not well supported. Dydimocampa and Venetocampa might be paraphyletic and Plusiocampa s. str. might contain two different monophyletic groups (Sendra 2003; Sendra et al. 2004). Furthermore, in the case of Dydimocampa, P. (D.) evallonychia, $P$. (D.) euxina and a probable new species found in a cave in southwestern Serbia (D. Antić leg.) seem very closely related. Species of Stygiocampa certainly form a monophyletic subgenus, sharing several common characters, such as the reduction of mesonotal and metanotal macrosetae, the absence of dorsal femoral macrosetae, and the presence of several extra urosternal macrosetae in four of these species. In addition, they are geographically restricted to subterranean ecosystems around the Dinaric and Balkan Mountains (Bareth \& Condé 2001). The monotypic Pentachaetocampa, with its five dorsal femoral macrosetae and the unique presence of glandular $g_{l}$ setae in females, is only found in a cave in southwestern Germany (Sendra \& Weber 2018). Finally, Plusiocampa s. str., including 60 species and 10 subspecies, is widespread across the entire European and Mediterranean region (Table 13, Fig. 211; see also Table S1 in Supplementary Material). The two suggested monophyletic groups within Plusiocampa are characterized by two formula patterns in the distribution of notal macrosetae: the presence or the absence of medial posterior macrosetae or submacrosetae on the mesonotum and metanotum. A peculiar distribution formula pattern is revealed using this taxonomical criterion. Part of Plusiocampa s. str., specifically 25 species and 6 subspecies that do not have medial posterior or intermediate thoracic macrosetae, occupy the ancient European plates, the current Dinaric and Catalonian regions. The other 35 species and 4 subspecies of Plusiocampa s. str., which have medial posterior thoracic macrosetae, occupy more recently emerged plates in the east and west of the emerged Mediterranean plates (Table 13, Fig. 212; see also Table S1 in Supplementary Material) (Sendra et al. 2004).

The tachycampoid lineage is less diversified than Plusiocampinae. It has four genera and eight species in the Eastern Mediterranean region (Table 14, Fig. 209; see also Table S1 in Supplementary Material). Three of these genera have amphi-Atlantic distributions, with species in Mesoamerica (Oncinocampa, Paratachycampa and Tachycampa) and Brazil (Oncinocampa) (Bareth \& Condé 1981; Sendra et al. 2016).

\section{Habitats and troglomorphism}

Campodeids were considered by Racovitză (1907: 426-427, 443) as "le Cavernicole idéal", the ideal troglobite. All campodeids are eyeless with positive thigmotactism, they have a soft body with a tracheal respiratory system and a thin cuticle, traits associated with a cryptic, subsurface life-style. Many campodeids, mainly within Plusiocampinae and the tachycampoids, inhabit the deep subterranean 
SENDRA A. et al., Euro-Mediterranean Plusiocampinae and tachycampoid diplurans

Table 13 (continued on next two pages). Genera, subgenera, species, subspecies and affinis forms of Plusiocampinae Paclt, 1957 in the Euro-Mediterranean Region.

\begin{tabular}{|c|c|c|}
\hline Taxon & Habitat & Distribution \\
\hline Cestocampa Condé, 1955 & hypogean & Southern Euro-Mediterranean Region \\
\hline C. balcanica Condé, 1955 & edaphic & Dinaric Mountains and Italian Peninsula \\
\hline C. gasparoi Bareth, 1988 & subterranean & Southern Italian Peninsula \\
\hline C. iberica Sendra \& Condé 2012 & subterranean & Eastern Iberian Peninsula \\
\hline C. italica (Silvestri, 1912) & edaphic & Dinaric Mountains and Italian Peninsula \\
\hline Hystrichocampa pelletieri Condé, 1948 & subterranean & Jura Mountains (France and Switzerland) \\
\hline Patrizicampa sardoa Condé, 1962 & subterranean & Eastern Sardinia \\
\hline Plusiocampa Silvestri, 1912 & hypogean & Euro-Mediterranean Region \\
\hline Plusiocampa (Dydimocampa) Paclt, 1957 & subterranean & European Region \\
\hline P. (D.) alhamae Condé \& Sendra, 1989 & subterranean & Southern Iberian Peninsula \\
\hline P. (D.) euxina Condé, 1996 & subterranean & Movile Cave, Dobruja (Romania) \\
\hline P. (D.) evallonychia Silvestri, 1949 & subterranean & Crimean Peninsula \\
\hline $\begin{array}{l}\text { Plusiocampa (Pentachaetocampa) inopinata } \\
\text { Sendra \& Weber, } 2018\end{array}$ & subterranean & South Black Forest (Germany) \\
\hline Plusiocampa (Plusiocampa) s. str. Silvestri, 1912 & hypogean & Euro-Mediterranean region \\
\hline $\begin{array}{l}\text { Plusiocampa (Plusiocampa) s. str. (with medial } \\
\text { posterior or intermediate macrosetae) }\end{array}$ & hypogean & Central, Southern and Southeastern Europe \\
\hline P. (P.) apollo Sendra, Giachino \& Vailati sp. nov. & MSS & Southern Balkan Peninsula (Greece) \\
\hline P. (P.) beroni Bareth \& Condé, 2001 & subterranean & Balkan Mountains (Bulgaria) \\
\hline P. (P.) bonadonai bonadonai Condé, 1948 & subterranean & Provence Alps (France) \\
\hline P. (P.) bonadonai lanzai Condé, 1961 & subterranean & Valais (Switzerland) and Northern Apennines (Italy) \\
\hline P. (P.) bonadonai pavani Condé \& Poivre, 1982 & subterranean & Lombardy (Italy) \\
\hline P. (P.) breuili Condé, 1955 & subterranean & Pityuses, Balearic Islands \\
\hline P. (P.) aff. breuili Condé, 1955 & subterranean & Southeastern Iberian Peninsula \\
\hline P. (P.) bulgarica Silvestri, 1931 & subterranean & Balkan and Rhodope Mountains (Bulgaria) \\
\hline P. (P.) caprai Condé, 1950 & hypogean & Alps \\
\hline P. (P.) chiosensis Sendra \& Gasparo sp. nov. & subterranean & Chios (Greece), coast of Anatolian Peninsula \\
\hline P. (P.) dublanskii Sendra \& Turbanov sp. nov. & subterranean & Crimean Peninsula \\
\hline P. (P.) aff. dublanskii Sendra \& Turbanov sp. nov. & subterranean & Western Caucasus \\
\hline P. (P.) elongata Ionescu, 1955 & subterranean & Carpathian Mountains (Romania) \\
\hline P. (P.) aff. elongata Ionescu, 1955 & subterranean & Peştera Cloşani, Carpathian Mountains (Romania) \\
\hline P. (P.) fagei Condé, 1955 & subterranean & Tramuntana Mountains, Mallorca, Balearic Islands \\
\hline P. (P.) festae Silvestri, 1932 & hypogean & Aegean Islands and Anatolian Peninsula \\
\hline P. (P.) friulensis Bareth \& Condé, 1984 & subterranean & Carnic Pre-Alps (Italy) \\
\hline P. (P.) glabra Condé, 1984 & subterranean & Southern Balkan Peninsula \\
\hline P. (P.) grandii Silvestri, 1933 & subterranean & Italian Alps \\
\hline P. (P.) aff. grandii Silvestri, 1933 & subterranean & Southern Balkan Peninsula \\
\hline P. (P.) hoelzeli (Neuherz, 1984) & subterranean & Austrian and Slovenian Alps \\
\hline P. (P.) hoffmanni Sendra \& Paragamian sp. nov. & subterranean & Crete (Greece) \\
\hline P. (P.) humicola Ionescu, 1951 & edaphic & Carpathians Mountains (Romania) \\
\hline P. (P.) hystricula Bareth \& Condé, 1984 & subterranean & Italian Alps \\
\hline P. (P.) lagari Sendra \& Condé, 1987 & subterranean & Baetic Mountains Range (Spain) \\
\hline
\end{tabular}


Table 13 (continued). Genera, subgenera, species, subspecies and affinis forms of Plusiocampinae Paclt, 1957 in the Euro-Mediterranean Region.

\begin{tabular}{|c|c|c|}
\hline Taxon & Habitat & Distribution \\
\hline P. (P.) lagoi Silvestri, 1932 & hypogean & Ródos (Greece) \\
\hline P. (P.) aff. lagoi Silvestri, 1932 & hypogean & Dinaric Mountains (Croatia) \\
\hline P. (P.) lucenti Sendra \& Condé, 1986 & subterranean & $\begin{array}{l}\text { East Pre-Baetic Mountains, } \\
\text { Eastern Iberian Peninsula }\end{array}$ \\
\hline P. (P.) magdalenae Condé, 1957 & subterranean & Alpes de Provence (France) \\
\hline P. (P.) notabilis Silvestri, 1912 & edaphic & Southern Italian Peninsula \\
\hline P. (P.) provincialis provincialis Condé, 1949 & subterranean & Alpes de Provence (France) \\
\hline P. (P.) provincialis praedita Condé, 1949 & subterranean & Alpes de Provence (France) \\
\hline P. (P.) rhea Sendra sp. nov. & hypogean & Crete (Greece) \\
\hline P. (P.) romana Condé, 1954 & subterranean & Central Apennine Mountains, Italian Peninsula \\
\hline P. (P.) rudnica Blesic, 1992 & edaphic & Western Balkan Peninsula (Serbia) \\
\hline P. (P.) rybaki Condé, 1956 & subterranean & Southern Balkan Peninsula \\
\hline P. (P.) sardiniana Condé, 1981 & subterranean & Sardinia \\
\hline P. (P.) socia Condé, 1983 & subterranean & Eastern Sardinia \\
\hline P. (P.) spelaea Stach, 1930 & hypogean & Western Carpathians \\
\hline P. (P.) suspiciosa Condé \& Mathieu, 1957 & hypogean & (dubious locality) \\
\hline P. (P.) strouhali strouhali Silvestri, 1933 & subterranean & Austrian, Italian and Slovenian Alps \\
\hline P. (P.) strouhali cavicola Vornatscher, 1943 & subterranean & Austrian and Slovenian Alps \\
\hline P. (P.) tinoamorei Sendra \& Nicolosi, 2019 & subterranean & Southeastern Sicily \\
\hline P. (P.) vodniensis Bareth \& Condé, 2001 & subterranean & Balkan Mountains (Bulgaria) \\
\hline $\begin{array}{l}\text { Plusiocampa (Plusiocampa) s. str. (without medial } \\
\text { posterior and intermediate macrosetae) }\end{array}$ & hypogean & European Basin \\
\hline P. (P.) affinis Condé, 1947 & hypogean & Dinaric Mountains (Montenegro) \\
\hline P. (P.) arbanasiensis Bareth \& Condé, 2001 & hypogean & Balkan Mountain and Dinaric Mountains \\
\hline P. (P.) baetica Sendra, 2004 & subterranean & $\begin{array}{l}\text { Internal zone of Baetic Mountain Range, Southern } \\
\text { Iberian Peninsula }\end{array}$ \\
\hline P. (P.) balsani Condé, 1947 & subterranean & Central Massif (France) \\
\hline P. (P.) bonneti bonneti Condé, 1948 & subterranean & $\begin{array}{l}\text { Central Pyrenees and Pre-Pyrenees } \\
\text { (France and Spain) }\end{array}$ \\
\hline P. (P.) bonneti condei Sendra \& Escolà, 2004 & subterranean & $\begin{array}{l}\text { Eastern Pyrenees and Catalan Mediterranean } \\
\text { Mountain System }\end{array}$ \\
\hline P. (P.) bonneti deharvengi Bareth \& Condé, 1996 & subterranean & Eastern Pyrenees \\
\hline P. (P.) breviantennata Loksa, 1960 & hypogean & Southern Transdanubian Mountains (Hungary) \\
\hline P. (P.) corcyraea corcyraea Silvestri, 1912 & edaphic & Southern Balkan Peninsula and Corfu \\
\hline P. (P.) corcyraea abdominalis Condé, 1984 & edaphic & Ithakia (Greece) \\
\hline P. (P.) cyrnensis Condé, 1953 & edaphic & Corsica \\
\hline P. (P.) dallai Bareth \& Condé, 1984 & subterranean & $\begin{array}{l}\text { Gargano Promontory on the Apulian Carbonate } \\
\text { Platform, Italian Peninsula }\end{array}$ \\
\hline P. (P.) dargilani (Moniez, 1894) & subterranean & Grands Causses (France) \\
\hline P. (P.) djurdjurae Condé, 1984 & subterranean & Djurdjura Mountains, Tell Atlas (Algeria) \\
\hline P. (P.) dobati Condé, 1975 & subterranean & Swanian Alb (Germany) \\
\hline P. (P.) dolichopoda Bareth \& Condé, 1984 & subterranean & $\begin{array}{l}\text { Gargano Promontory on the Apulian Carbonate } \\
\text { Platform, Italian Peninsula }\end{array}$ \\
\hline P. (P.) exsulans Condé, 1947 & hypogean & Central Europe, Italian and Dinaric Mountains \\
\hline
\end{tabular}


SENDRA A. et al., Euro-Mediterranean Plusiocampinae and tachycampoid diplurans

Table 13 (continued). Genera, subgenera, species, subspecies and affinis forms of Plusiocampinae Paclt, 1957 in the Euro-Mediterranean Region.

\begin{tabular}{|c|c|c|}
\hline Taxon & Habitat & Distribution \\
\hline P. (P.) gadorensis Sendra, 2001 & subterranean & Sierra Gador, Southeast Iberian Peninsula \\
\hline P. (P.) gueorguievi Bareth \& Condé, 2001 & subterranean & Stara Planina (Bulgaria) \\
\hline P. (P.) isterina Condé, 1993 & hypogean & Movile Cave, Dobruja (Romania) \\
\hline P. (P.) aff. isterina Condé, 1993 & subterranean & Dinaric Mountains (Bosnia and Herzegovina) \\
\hline P. (P.) latens Condé, 1948 & hypogean & Dinaric Mountains (Bosnia and Herzegovina) \\
\hline P. (P.) aff. latens Condé, 1948 & hypogean & Dinaric Mountains (Croatia) \\
\hline P. (P.) lindbergi Condé, 1956 & hypogean & Greek Macedonia, Balkan Peninsula \\
\hline P. (P.) pouadensis pouadensis (Denis, 1930) & subterranean & Eastern Pyrenees (France) \\
\hline P. (P.) pouadensis fouresi Condé, 1956 & subterranean & Eastern Pyrenees (France) \\
\hline P. (P.) pouadensis leoni Condé, 1951 & subterranean & Eastern Pyrenees (Spain) \\
\hline P. (P.) schweitzeri Condé, 1947 & subterranean & Dinaric Mountains (Bosnia and Herzegovina) \\
\hline P. (P.) aff. schweitzeri Condé, 1947 & subterranean & Northeast Anatolian Peninsula \\
\hline P. (P.) solerii Silvestri, 1932 & edaphic & Ródos (Greece) and Izmir (Anatolian Peninsula) \\
\hline P. (P.) aff. solerii Silvestri, 1932 & subterranean & Cyprus \\
\hline P. (P.) ternovensis Sendra \& Borko sp. nov. & subterranean & Dinaric Mountains (Slovenia) \\
\hline P. (P.) vedovinii Condé, 1981 & subterranean & Alpes de Provence (France) \\
\hline Plusiocampa (Stygiocampa) Silvestri, 1934 & subterranean & Dinaric Mountains and Balkan Mountains \\
\hline P. (S.) bureschi Silvestri, 1931 & subterranean & Balkan Mountains (Bulgaria) \\
\hline P. (S.) christiani Condé \& Bareth, 1966 & subterranean & $\begin{array}{l}\text { Kučaj and Beljanica Mts, part of } \\
\text { Balkan Mt System (Serbia) }\end{array}$ \\
\hline P. (S.) dalmatica Condé, 1959 & subterranean & $\begin{array}{l}\text { Dinaric Mountains (Italy, Bosnia and Herzegovina, } \\
\text { Croatia and Slovenia) }\end{array}$ \\
\hline P. (S.) denisi Condé, 1947 & subterranean & Dinaric Mountains (Serbia) \\
\hline P. (S.) nivea (Joseph, 1882) & subterranean & Dinaric Mountains (Croatia, Italy and Slovenia) \\
\hline P. (S.) remyi Condé, 1947 & subterranean & $\begin{array}{l}\text { Dinaric Mountains (Bosnia and Herzegovina, } \\
\text { Croatia and Montenegro) }\end{array}$ \\
\hline P. (S.) aff. remyi Condé, 1947 & subterranean & Dinaric Mountains (Croatia) \\
\hline Plusiocampa (Venetocampa) Bareth \& Condé, 1984 & subterranean & Italian and Slovenian Alps \\
\hline P. (V.) ferrani Sendra \& Delić sp. nov. & subterranean & Slovenian Alps \\
\hline P. (V.) paolettii Bareth \& Condé, 1984 & subterranean & Italian Alps \\
\hline Vandelicampa tisserandi Condé, 1955 & subterranean & Middle East (Lebanon) \\
\hline
\end{tabular}

environment and show troglomorphic adaptations: elongation of the body and appendages, including the increase and complexity of their sensory organs. These traits are associated with a troglomorphic evolution of morphological characters (Christiansen 1965).

Only 11 of 97 taxa of Plusiocampinae inhabit edaphic environments, with a clear preference for humid habitats (Table 13, Fig. 213). All edaphic species have smaller bodies compared to subterranean Plusiocampinae. They have shorter appendages and a lower number of cercal articles (up to seven) and antennomeres (18 to 27), which are all doliiform. Their cupuliform organs are simple and enclose four olfactory chemoreceptors with one simple fold. Species found in soils, but also in shallow subterranean habitats (MSS) and caves, have slightly longer bodies, elongated appendages and an increased number of antennomeres (from 19 to 32), cercal articles and olfactory chemoreceptors. Currently, 13 taxa of Plusiocampinae and one species of tachycampoid (O. placti) can be considered as non-troglomorphic, 

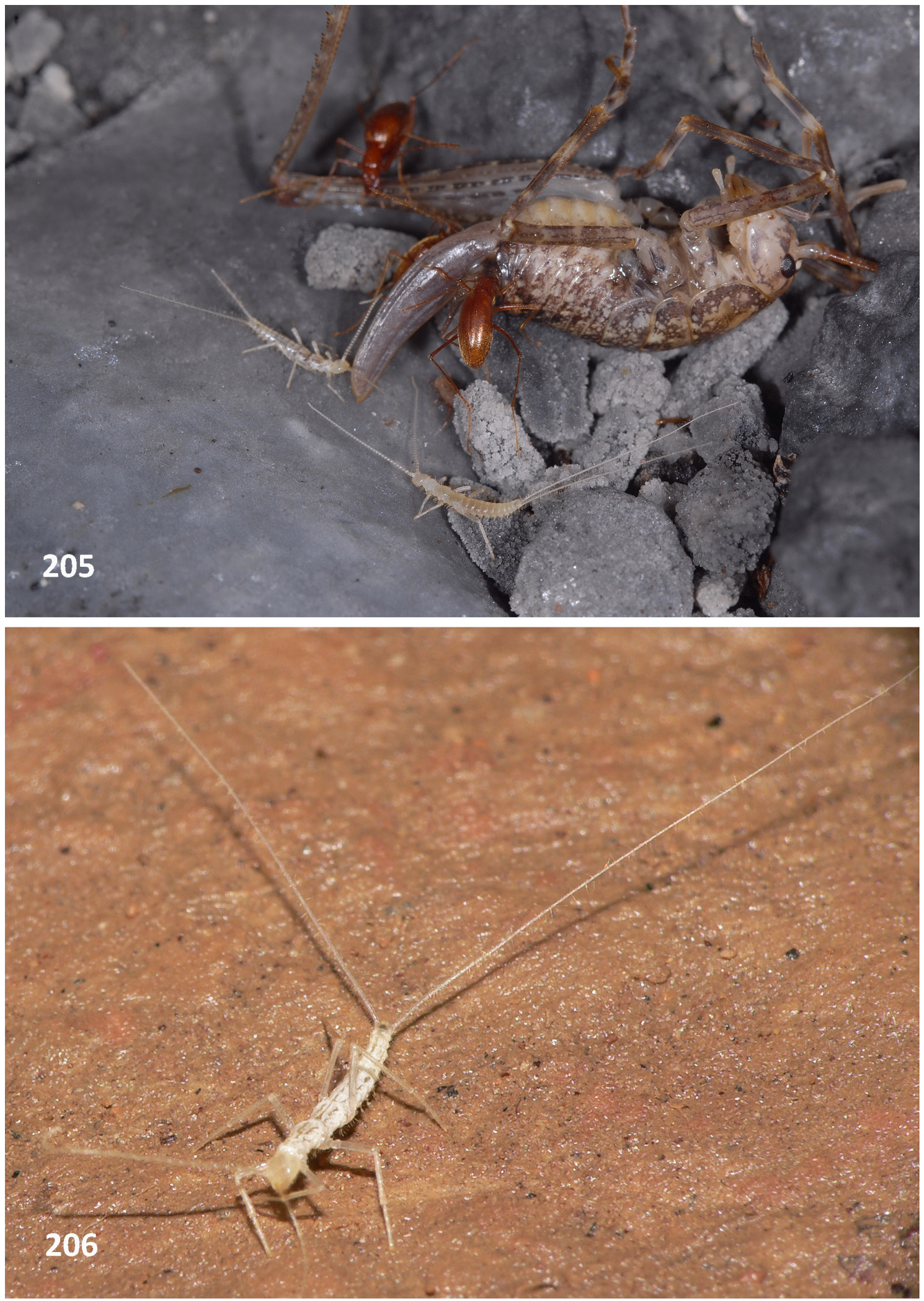

Figs 205-206. 205. Plusiocampa (Stygiocampa) dalmatica Condé, 1959 and the beetle Parapropus vitorogensis Ćurčić et al., 2012 (Leptodirini) feeding on a dead cave cricket, Troglophilus sp., in Vaganska pećina, Bosnia and Herzegovina (photo: Slavko Polak). 206. Paratachycampa hispanica Bareth \& Condé, 1981, from Cirat Cave, Castellón, Spain (photo: Sergio Montagud). 

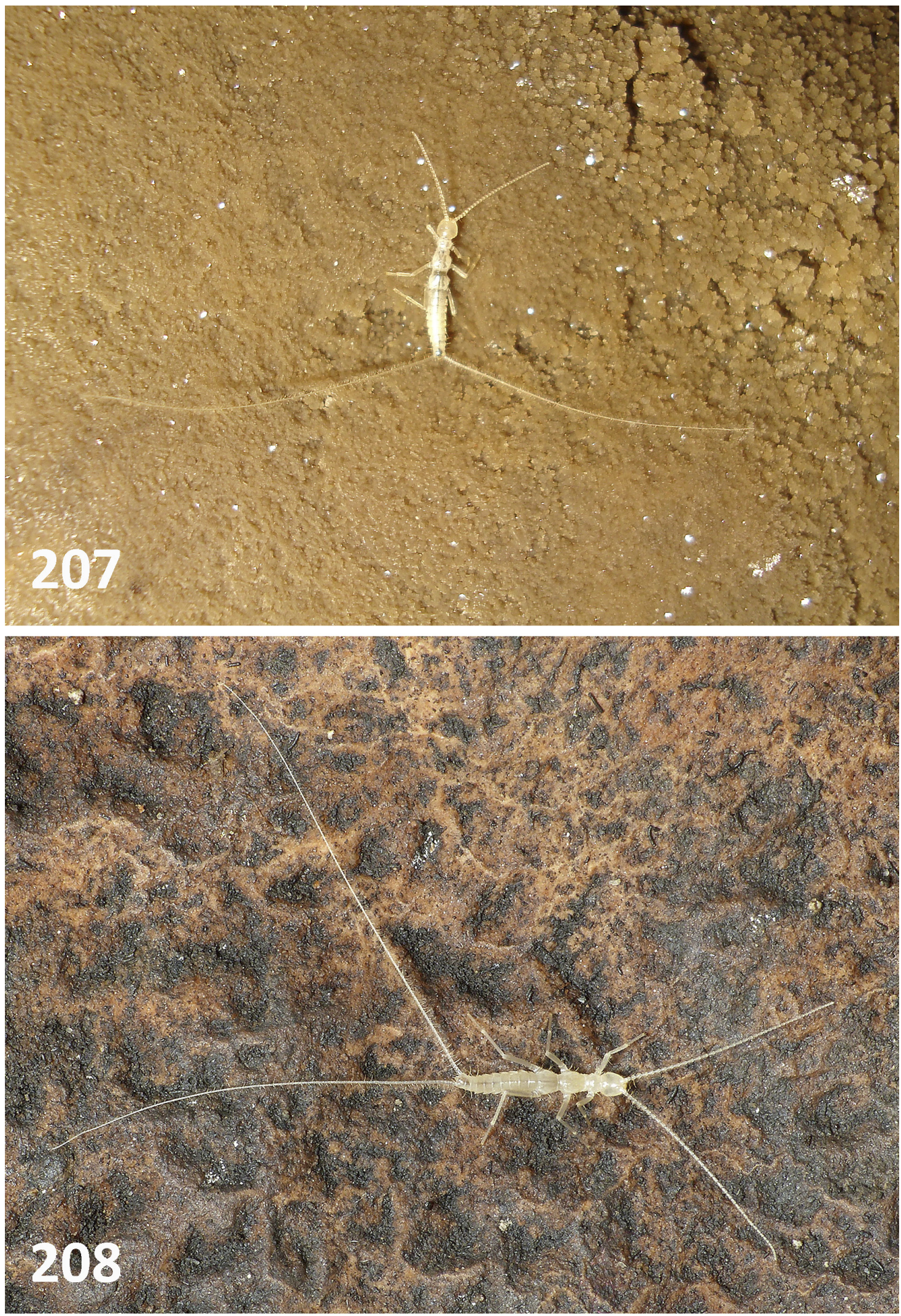

Figs 207-208. 207. Plusiocampa (Stygiocampa) nivea (Joseph, 1882), from Košanski spodmol (n. 902) Obrov, Podgrad, Slovenia (photo: Fulvio Gasparo). 208. Plusiocampa (Stygiocampa) dalmatica Condé, 1959, from Grotta Bac, VG 49, 400 m a.s.l., Trieste, Italy (photo: Fulvio Gasparo). 
Table 14. Tachycampoid species and affinis forms in the Euro-Mediterranean Region.

\begin{tabular}{lll}
\hline Taxon & Habitat & Distribution \\
\hline Jeannelicampa stygia Condé, 1952 & subterranean & Tell Atlas (Algeria) \\
Oncinocampa Condé, 1982 & hypogean & Cantabric Mountains, Northern Iberian Peninsula, and E Sardinia \\
O. asonensis Sendra \& Condé, 1988 & subterranean & Cantabric Mountains, Northern Iberian Peninsula \\
O. falcifer Condé, 1982 & subterranean & Cantabric Mountains, Northern Iberian Peninsula \\
O. aff. falcifer Condé, 1982 & subterranean & Cantabric Mountains, Northern Iberian Peninsula \\
O. genuitei Bareth, 1989 & subterranean & Picos de Europa, Cantabric Mountains, Northern Iberian Peninsula \\
O. paclti Condé, 1981 & hypogean & E Sardinia \\
Paratachycampa Wygodzinsky, 1944 & subterranean & Southern North America and Eastern Iberian Peninsula \\
P. hispanica Bareth \& Condé, 1981 & subterranean & Eastern Iberian Peninsula \\
P. penyoensis Bareth \& Condé, 1981 & subterranean & Calderona Massif, Eastern Iberian Peninsula \\
Tachycampa Silvestri, 1936 & subterranean & Mesoamerica and Middle Atlas (Morocco) \\
T. lepineyi Silvestri, 1936 & subterranean & Middle Atlas (Morocco) \\
\hline
\end{tabular}

occupying a wide variety of hypogean habitats from edaphic to shallow subterranean habitats (MSS) and occasionally caves (Table 14, Fig. 213). Several of these hypogean species are almost only reported from MSS habitats. This is the case for $P$. (P.) festae and $P$. (P.) apollo sp. nov., as has been shown by the sampling effort carried out mainly in Greece by P.M. Giachino and D. Vailati in MSS habitats, both in karst and non-karst areas. The marked preference of these two species for MSS habitats has also been observed in other diplurans and collembolans studied in colluvial and alluvial MSS (Bareth 1983; Ortuño et al. 2013; Baquero et al. 2017; Sendra et al. 2017b). Nevertheless, the most frequent habitats for most of the Plusiocampinae and tachycampoids are the subterranean spaces in the vadose zone of the bedrock. A total of 73 species, subspecies or affinis forms of Plusiocampinae and eight species of tachycampoids inhabiting the Euro-Mediterranean region are cave-dwelling species - named in the text as subterranean species - found mostly in caves, with clear troglomorphic features (Tables 13-14, Fig. 213; see also Table S1 in Supplementary Material). They have larger bodies, up to $9 \mathrm{~mm}$; the antennae are up to $2 \times$ and the cerci up to $3 \times$ as long as the body length. Furthermore, the antennae have more than 30 antennomeres, although there are a few exceptions in which a smaller number of antennomeres could be an indication of a regenerated antenna. Some species of Plusiocampinae, such as $P$. (P.) gadorensis and $P$. (P.) hoffmanni sp. nov. (Table 6) have 50 antennomeres and there are up to 54 in $P$. (P.) chiosensis sp. nov. and $P$. (S.) bureschi (Bareth \& Condé 2001; Sendra 2001). In the tachycampoid O. asonensis, the antennae have up to 64 antennomeres (Sendra \& Condé 1988). The antennomeres of these highly troglomorphic species are usually elongated, the middle antennomeres being $2 \times$ or $3 \times$ as long as wide. Another remarkable troglomorphic trait is the length of the cerci (Tables 1, 4-5, 8, 11), with clear differences between the non-troglomorphic species such as $P$. $(P$.) spelaea, showing cerci shorter than the body length $(0.4-0.5 \times$ as long) (Table 10$)$, the slightly troglomorphic species such as $P$. $(P$.) strouhali cavicola and $P$. (P.) hoelzeli (Tables 5, 11), with cerci somewhat longer than the body, and the most troglomorphic species such as $P$. (D.) evallonychia and $P$. (P.) hoffmanni sp. nov. (Tables 1,8 ), with cerci almost twice as long as the body. The longest cerci of all Plusiocampinae have been recorded in $P$. (P.) chiosensis sp. nov., with cerci $2.52 \times$ as long as the body length (Table 4). A recent study of cerci elongation in campodeids suggests that the elongation of these appendages is an adaptation to improve sensitivity in subterranean environments, with two different growth patterns: the cerci of Campodeinae and Lepidocampinae have a positive allometric growth, whereas it is isometric in Plusiocampinae (Sendra et al. 2017a). This difference between subfamilies might be regarded as an adaptation to the different habitats they colonize. While the majority of species of Campodeinae and Lepidocampinae are non-troglobites, many of them being edaphic-endogean species thriving in the small spaces of the soil, most species of Plusiocampinae are troglobites inhabiting the deep subterranean ecosystems. 
Another remarkable progressive troglomorphic trait in campodeid species is the notable increase of complexity in shape, size and abundance of the sensorial equipment on the antennae. Although the troglomorphic species have a similarly invariable number of trichobothria as epigean species, they have longer flagella. The gouge sensilla (with an unknown function) were first described in two highly troglomorphic species of Paratachycampa (Bareth \& Condé 1981) and later found in all campodeid species (Reboleira et al. 2010; Sendra et al. 2010). Furthermore, troglomorphic campodeids show some differences in gouge sensilla compared with non-troglomorphic campodeids; in the troglobites they are more abundant (up to 20) and are usually, but not always, longer and thinner than in nontroglomorphic taxa (Sendra et al. 2017c). The most remarkable changes in the sensory organs caused by a subterranean life-style are observed in the olfactory chemoreceptors of the cupulifom organ. Olfactory chemoreceptors are spheroid sensilla surrounded by tiny folds or 'collarettes'. The cuticular invagination and the sensilla have a perforated surface, and these pores are more numerous in troglomorphic than in non-troglomorphic species (Juberthie-Jupeau \& Bareth 1980). Outstanding examples are found in many troglobites such as $J$. stygia, which has the highest known number of sensilla (28) in each cupuliform organ (Condé 1954c). The SEM observation of these chemoreceptors in a few species shows a great complexity of folds, with a multiperforated surface that adopts some spiral patterns in Plusiocampa (Figs 14-15, 30, 53-54, 95, 126, 128-130, 138, 140, 157-160). Other troglomorphic Plusiocampinae have more complex chemoreceptor shapes, such as Turkmenocampa mirabilis, with sphaeriform and ramiform chemoreceptors (Sendra et al. 2018), or the network of coralliform structures in an undescribed Plusiocampinae from southern Asia (Sendra, unpubl. data). Plusiocampinae and tachycampoids share convergent evolutionary traits associated with the selective pressures of subterranean ecosystems (see Culver 1982; Hüppop 2000; Christiansen 2012), where the absence of light and patchiness of nutrients might promote the lengthening of appendages (Culver 1982; Bellés 1987; Christiansen 2012; Sendra et al. 2017c).

The ecological role of Plusiocampinae and tachycampoids still has to be studied. Field and laboratory observations suggest that they might be secondary consumers in the food web. Plusiocampinae and tachycampoids feed on the remains of organic matter coming from the surface, microorganisms and fungi, but also on dead animals (Fig. 205). The observation of the digestive tube of troglomorphic species often reveals complete body parts of microarthropods, such as small acari or insect larvae (Sendra, pers. obs.). This has already been recorded for soil-dwelling campodeids, although very rarely (Gunn 1992), and might suggest an opportunistic predatory behavior.

Campodeids are often found in syntopy in edaphic habitats, which is less frequent in subterranean habitats. Up to four species of campodeids are known to live in the same cave (Bareth \& Condé 1981), and co-occurrence of two species is not rare (Condé 1948a). Data on the spatial distribution of cave Diplura within cave systems are scarce and we report here the presence of Plusiocampa (S.) nivea and $P$. (P.) ternovensis sp. nov. in two caves where they seem to be spatially segregated, occupying different cave depths (see Table S2 in Supplementary Material). These observations reveal a complex mutual relationship of syntopically occurring species pairs, as well as habitat preferences of certain species within the subterranean ecosystem.

\section{Paleobiogeography, dispersion and colonization of subterranean ecosystems}

Plusiocampinae and tachycampoids share strong troglomorphic features due to their hypogean life-style in deep subterranean ecosystems. They represent two of the most diversified, disperse and abundant groups of dipluran troglobites in karst areas of the Euro-Mediterranean region. Their current distribution suggests an old colonization of this region under different paleogeographical scenarios of the fragmented Tethys Sea. Distributions might be explained mainly through tectonic plates and microplate drift theory, and the dispersal, vicariance and extinction processes that have taken place for hundreds of millions of years. 
Following a chronological paleobiogeographical history, tachycampoids might be the oldest phyletic group of the Campodeidae. Their disjunct distribution across the Atlantic, encompassing limited distribution areas in karst regions in West Europe, Northwest Africa, Mesoamerica and East Brazil, supports the hypothesis of a Pangean origin during the Mesozoic. These facts also support the ancient colonization of subterranean ecosystems (Bareth \& Condé 1981; Sendra et al. 2016).

Due to the absence of dated molecular phylogenies, a plausible scenario is suggested based on morphological characters. Plusiocampinae might have originated in the center of Eastern Laurasia, from where they dispersed throughout European regions, reaching a few African karst areas, perhaps since the Eocene-Oligocene, when the closing of the Turgai Strait allowed the European-Asian connection (Decourt et al. 2000). At least two dispersal waves might have occurred for the two doubtful monophyletic groups of Euro-Mediterranean Plusiocampinae during the Cenozoic. These groups are separated by the absence or presence of medial posterior macrosetae on the mesonotum and metanotum (Sendra et al. 2004). Following these criteria, the ancestors of Plusiocampa s. str. without thoracic medial posterior macrosetae (Table 13, Fig. 212), Stygiocampa and Patrizicampa could have reached the fragmented Europe soon after the connection with Asia through the Turgai Strait. They might have dispersed around Europe up to the western European regions (western Occitania, Basque Country, Cantabrian and Lusitanian regions), where other members of the subfamily Campodeinae and the tachycampoids occurred, perhaps already occupying the subterranean habitats (Sendra 1988, 2003). These are the genera Podocampa Silvestri, 1932 and Litocampa Silvestri, 1933 among Campodeinae, and the genera Oncinocampa and Paratachycampa among tachycampoids.

This first dispersal wave might have been limited in Africa by the earlier presence of two tachycampoid genera, Tachycampa and Jeannelicampa, with an exception on the Kabylian microplate, which moved towards the African plate much later (Rosenbaum et al. 2002; Schettino \& Turco 2006). The wave of Plusiocampa without medial posterior macrosetae included the monotypic Patrizicampa of Sardinia, the subgenus Stygiocampa of the Dinaric Mountains and the Balkan System, and perhaps the subgenus Venetocampa of the Italian Mountains. This first dispersal could have settled and still be living today in

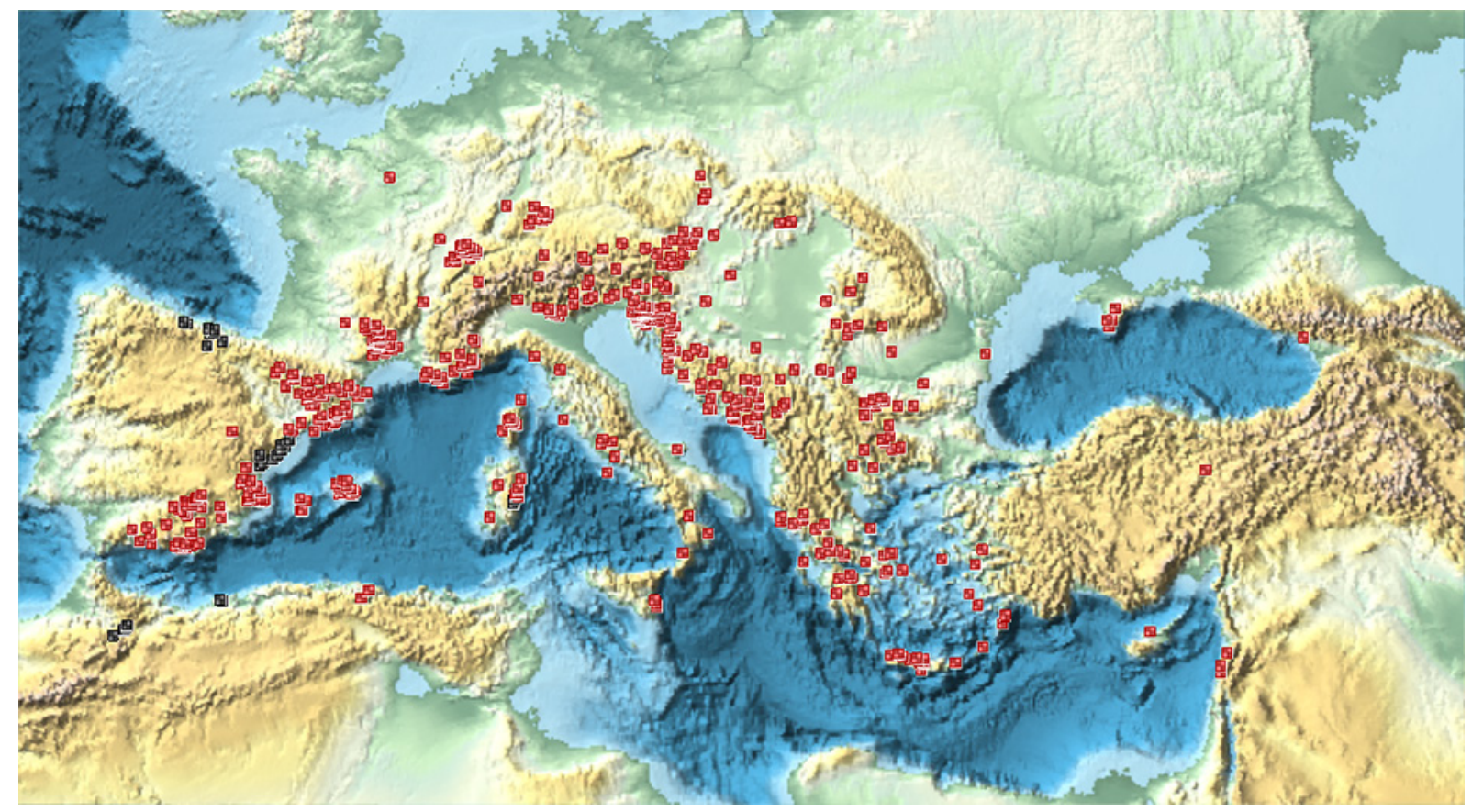

Fig. 209. Distribution map of Plusiocampinae Paclt, 1957 (red squares) and the tachycampoid phyletic group species (black squares) in the Euro-Mediterranean area. 


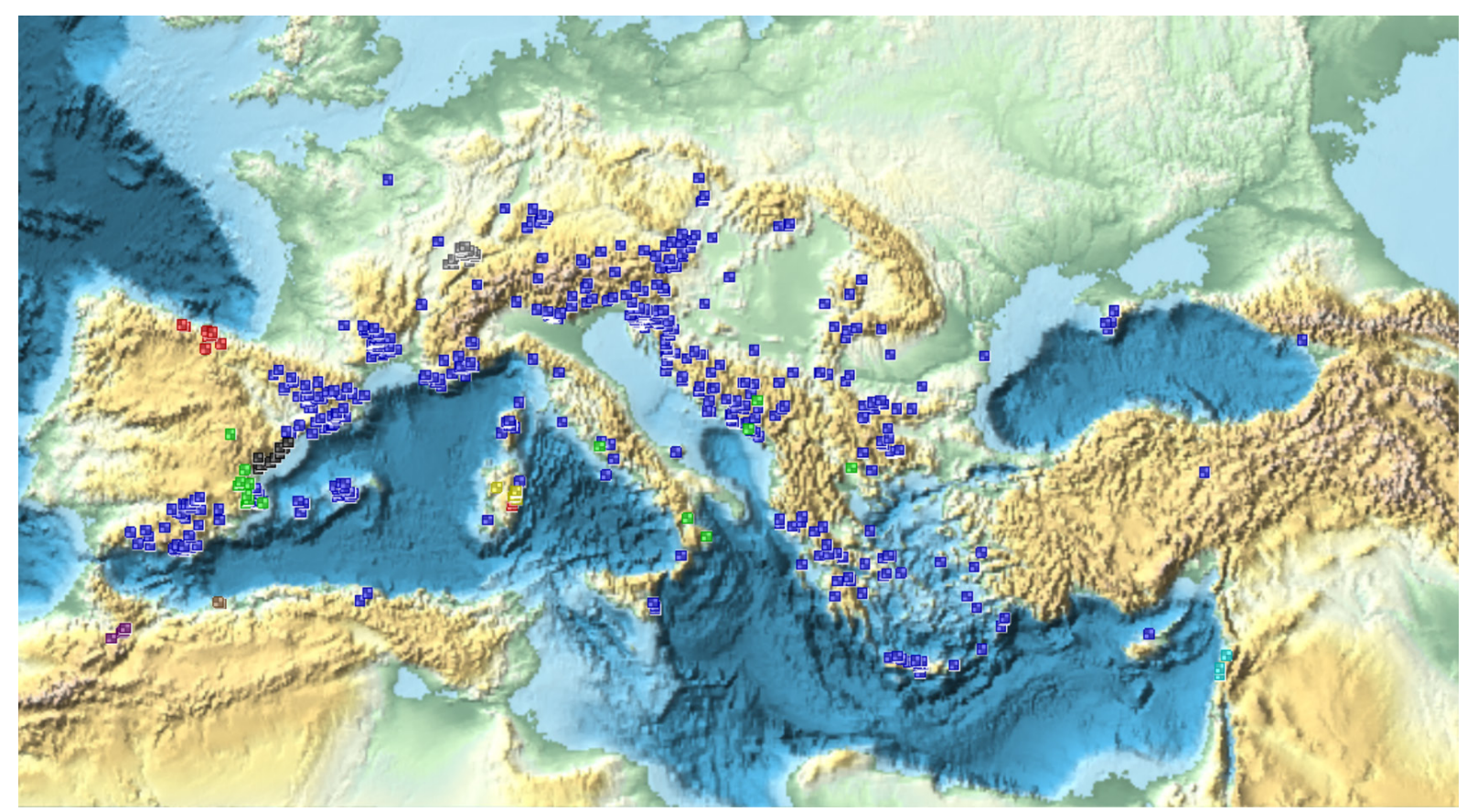

Fig. 210. Distribution map of Plusiocampinae Paclt, 1957 and tachycampoid phyletic group genera in the Euro-Mediterranean area: Cestocampa Condé, 1956 (green squares), Hystrichocampa Condé, 1948 (grey squares), Jeannelicampa Condé, 1952 (brown squares), Oncinocampa Condé, 1982 (red squares), Paratachycampa Wygodzinsky, 1944 (black squares), Patrizicampa Condé, 1956 (yellow squares), Plusiocampa Silvestri, 1912 (navy blue squares), Tachycampa Silvestri, 1936 (violet squares) and Vandelicampa Condé, 1955 (light blue squares).

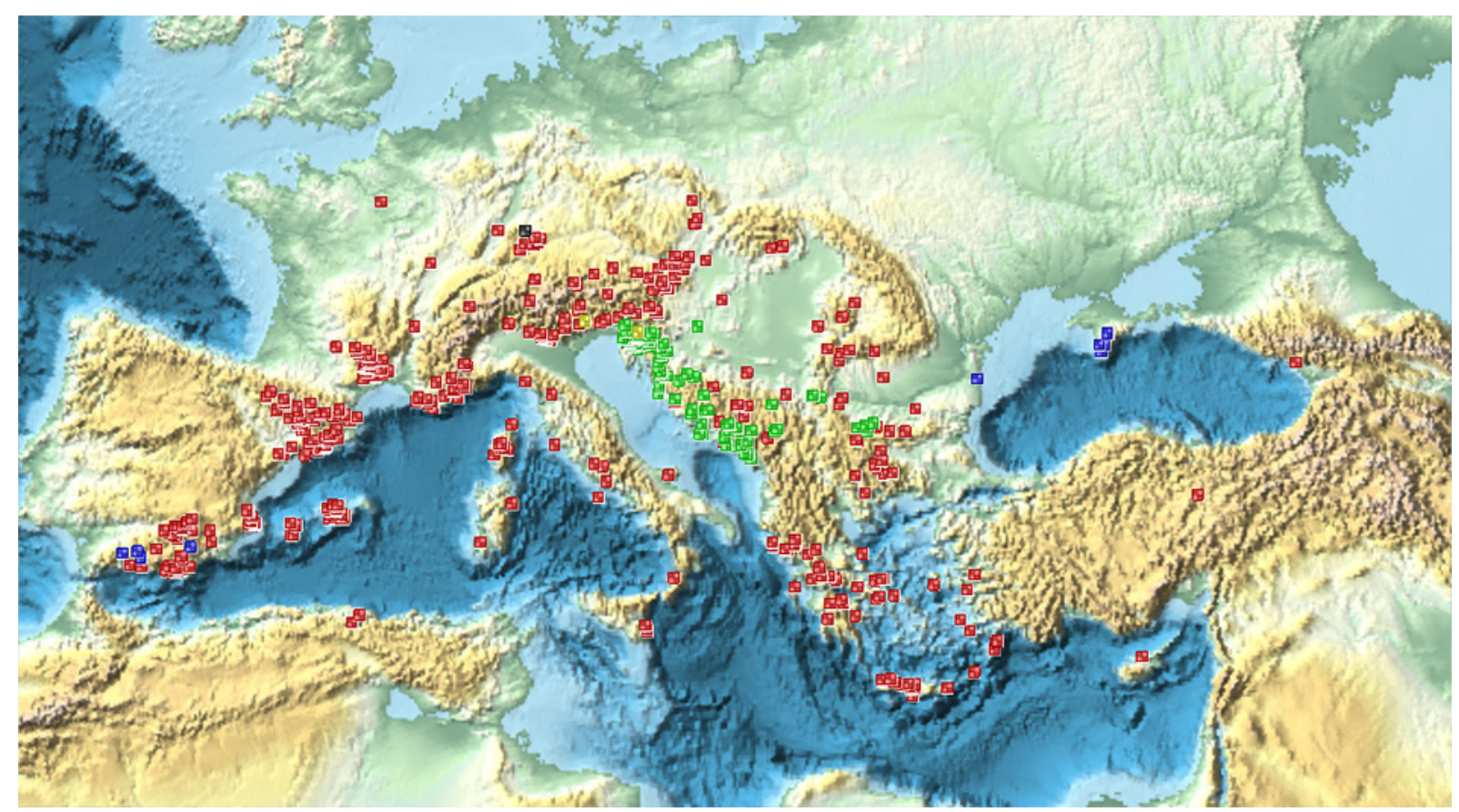

Fig. 211. Distribution map of subgenera of Plusiocampa Silvestri, 1912: Dydimocampa Paclt, 1957 (blue squares), Pentachaetocampa Sendra \& Weber, 2018 (black square), Plusiocampa s. str. (red squares), Stygiocampa Silvestri, 1934 (green squares) and Venetocampa Bareth \& Condé, 1984 (yellow squares). 
the Dinaric Alps, the isolated carbonate platform in Apulia and the later-fragmented eastern microplates of the Iberian Peninsula. This fragmentation of the eastern microplates (Santanach et al. 1986) explains the vicariant distribution of the Plusiocampinae found in French Provence, Catalonia, Sardinia, Kabylia

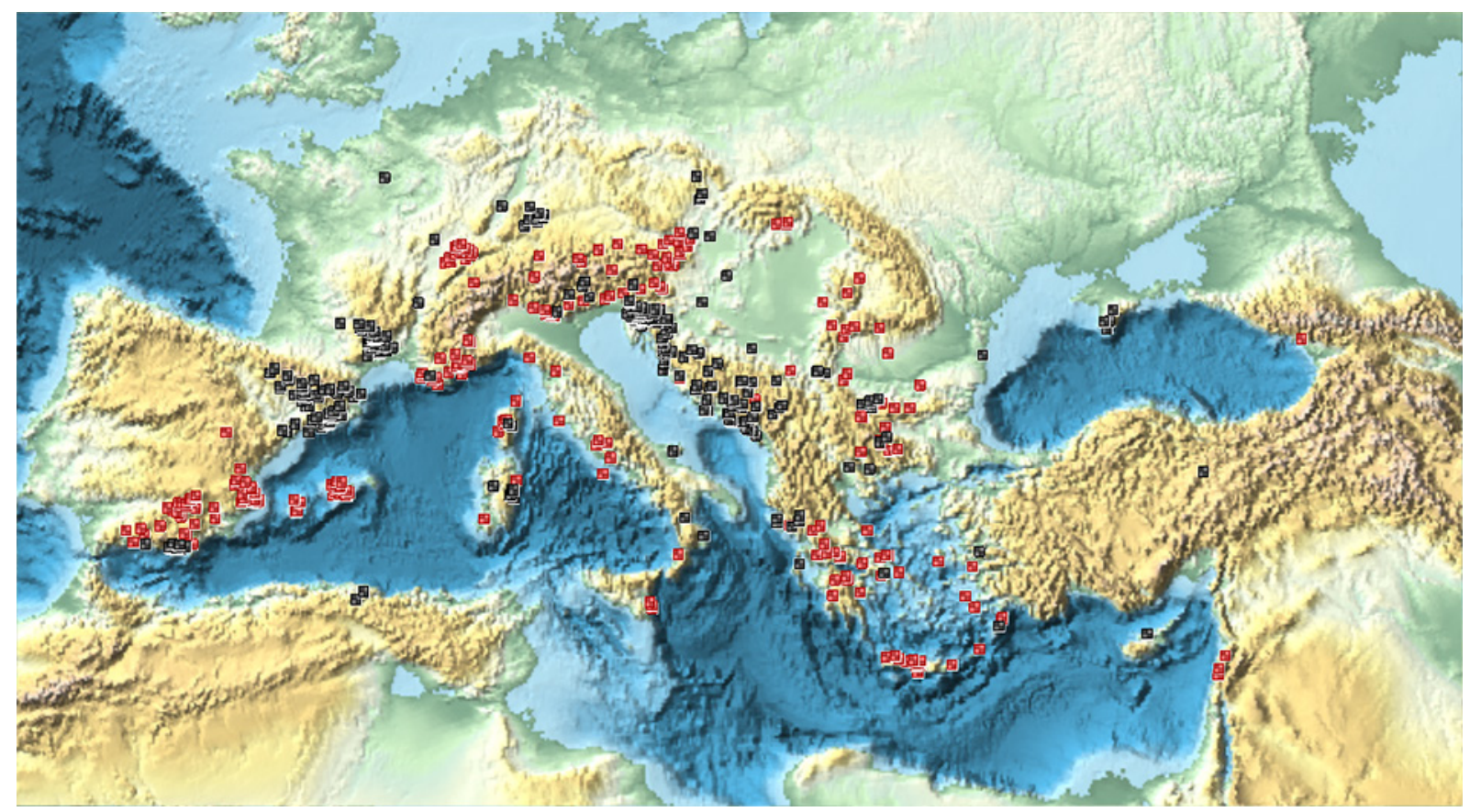

Fig. 212. Distribution map of species of Plusiocampinae Paclt, 1957 with medial posterior (or intermediate) notal macrosetae (red squares) and without these macrosetae (black squares).

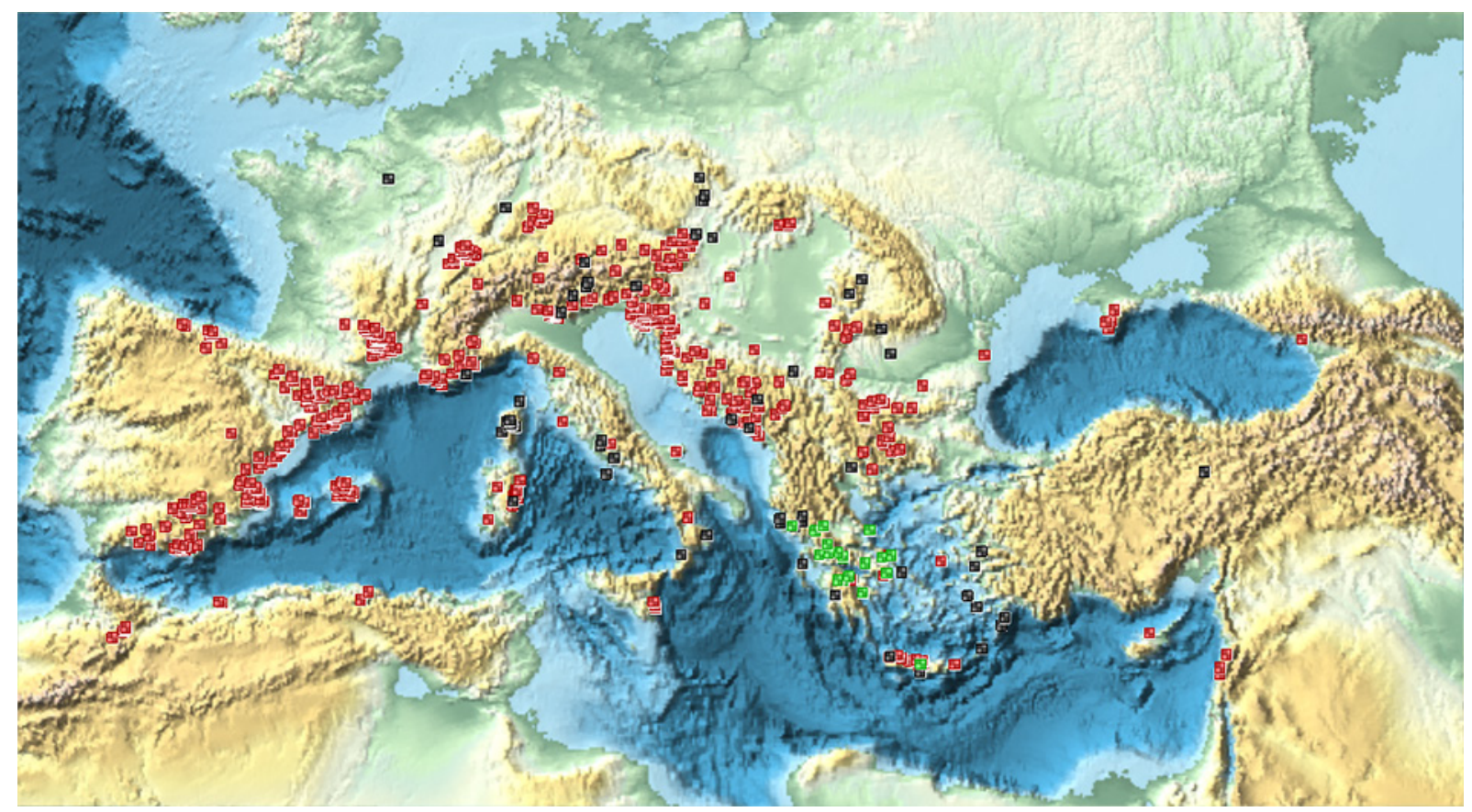

Fig. 213. Distribution map of Plusiocampinae Paclt, 1957 and tachycampoid phyletic lineage species in their habitats: subterranean, including natural and artificial caves (red squares), edaphic (black squares), MSS (green squares). 
SENDRA A. et al., Euro-Mediterranean Plusiocampinae and tachycampoid diplurans

and the rest of the Alboran plate in the Interior Zone of the Baetic Mountains (Fig. 212) (Sendra 2003; Sendra et al. 2004).

The second dispersal wave of the Plusiocampinae with thoracic medial posterior macrosetae (Table 13) could have happened much later, in the late Miocene, from Anatolia along the Miocenic Alps. This connection was open during this epoch (Rögl \& Steiniger 1984) and allowed their dispersal into the Apennine, Jura, Carpathian, Rhodopes, Crimean and Caucasus Mountains, and onto the Mediterranean islands, as has previously been suggested for Leptodirini beetles (Giachino et al. 1998; Moldovan \& Rajka 2007), so well represented in European subterranean ecosystems (Moldovan 2008). It is possible that these Plusiocampinae newcomers had reached the new lands emerged from the Tethys Sea on the Balkan Peninsula and the Aegean islands, Italian Peninsula, Rhône Valley, and Western Mediterranean, including the islands and the Pre-Baetic Mountains in the south of the Iberian Peninsula. The connected lands during the Messinian period might have allowed a much wider dispersion of Plusiocampa s. str., subgenera of Plusiocampa and genera of Plusiocampinae with $m p$ thoracic macrosetae. This could have been the case for species of Plusiocampa s. str., but also for Cestocampa balcanica, C. iberica, P. (Dydimocampa) alhamae, P. (P.) inopinata and the monotypic Hystrichocampa and Vandelicampa (Fig. 212) (Sendra 1988, 2003).

The present distribution areas of subterranean and edaphic Plusiocampinae and tachycampoids are probably not simply marked by ancient paleogeographic events, but might also have been affected during Pleistocene climatic changes. This could explain the total absence of Plusiocampinae and tachycampoids north of latitude $50^{\circ} \mathrm{N}$, which roughly follows the southern frontier of the Last Glacial Maximum from Belgium to Crimea. The same may have occurred for all other troglomorphic diplurans, with the remarkable exception of Haplocampa wagnelli Sendra, 2019. This fact was pointed out early by Racovitză (1907) and confirmed in recent cave biogeography studies (e.g., Culver et al. 2006). The absence of subterranean fauna would then be related to the lack of organic material, not reaching the caves and underground networks because of glaciation (Sendra \& Reboleira 2014; Jiménez-Valverde et al. 2017). All northern species of Plusiocampinae distributed near the limits of the Last Glacial Maximum are non-troglomorphic members of Plusiocampa, which have short antennae with doliiform antennomeres and four simple cupuliform sensilla, as well as a small body with short legs and cerci. This is the case for $P$. (P.) humicola, $P$. (P.) spelaea and P. (P.) corcyraea (Sendra \& Weber 2018). In this scenario of continuous climatic changes, Plusiocampinae and tachycampoid species that settled in northern European regions could have been wiped out several times during glacial periods. After these harsh climatic events, campodeids would not have been able to colonize or recolonize the subterranean habitats of northern Europe (Figs 209, 213).

During the Mesozoic and Cenozoic, the Plusiocampinae and tachycampoid groups of the EuroMediterranean regions probably suffered countless extinctions. These phyletic lineages could have undergone speciation and diversification by vicariance after the split of land masses. Over time, subterranean colonization would have occured when an empty niche was available (Sendra \& Reboleira 2014). As pointed out by Bellés (1991), survival (subterranean spaces as immediate refuges), opportunism (empty subterranean niches to colonize) or convenience (to escape from the competitive pressures of surface habitats) could be the main forces driving the colonization of deep meso- and macro-spaces underground.

Molecular phylogenetic studies are expected to shed new light on the systematics of Plusiocampinae and tachycampoids and may help us to understand their flourishing success in subterranean habitats, contributing to complete a better picture of the ancient colonization of the Euro-Mediterranean region. 


\section{Acknowledgements}

Thanks are due for their sampling efforts to Miguel Borreguero, Josiane Lips, Rika Bisa (Tsoumerka Park, Greece) and to members of the Croatian Biospeological Society for their sampling and for the loan of part of the Croatian Biospeological Society Collection. DS's field trips were funded by the Serbian Ministry of Education, Science and Technology (Grant 173038); KP was partially funded by the HISR project "Conservation of the Cave Fauna of Greece" funded by the MAVA Foundation and WWF Greece; PMG and DV carried out sampling in Greece using permits from the Ministry of Environment no. 124085/1362/2015, 135366/373/2016 and 166238/248/2018; IT was funded within the framework of the state assignment of FASO Russia (themes no. AAAA-A18-118012690106-7 and AAAA-A18-118012690105), supported in part by RFBR (project no. 17-54-40017Aбx_a); sampling efforts by AF and colleagues resulted from various projects on the evolution of cave fauna diversity, some of them funded by the German Research Foundation, DFG (DFG FA 1042/1-1 and DFG BA 2152/14-1); PMG and DV were partly supported by the program "Research Missions in the Mediterranean Basin" sponsored by the World Biodiversity Association onlus XLI contribution; ASPSR was supported by a research grant (15471) from Villum Fonden. Many thanks to the SEM facility of the Universitat de València, especially to Enrique Navarro, Pilar Gómez and Rafael Benito, and to Katie Marzen for English revision of the text. The authors are also very grateful to Dr Pedro Oromí (Laguna University, Tenerife, Canary Islands) for the revision.

\section{References}

Baquero E., Ledesma E., Gilgado J.D., Ortuño V.M. \& Jordana R. 2017. Distinctive Collembola communities in the Mesovoid Shallow Substratum: First data for the Sierra de Guadarrama National Park (Central Spain) and a description of two new species of Orchesella (Entomobryidae). PLoS One 12 (12): e0189205. https://doi.org/10.1371/journal.pone.0189205

Bareth C. 1968. Biologie sexuelle et formations endocrines de Campodea remyi Denis (Diploures Campodéidés). Revue d'Écologie et de Biologie du Sol 5 (3): 303-426.

Bareth C. 1983. Diploures Campodéidés du milieu souterrain superficiel de la Région Ariegeoise. Mémoires de Biospéologie 10: 67-71.

Bareth C. 1988. Campodés cavernicoles de la Vénétie orientale (Frioule, Vénétie Julienne) et de la Calabre (Insecta, Aprtérygota Diplura). Atti e Memorie della Commissione Grotte "Eugenio Boegan" 27: 45-55.

Bareth C. 1989. Une nouvelle espèce d'Oncinocampa récoltée dans une grotte des Picos de Europa (Nord de l'Espagne): Oncinocampa genuitei n. sp. (Insecta, Apterygota, Campodeidae). Mémoires de Biospéologie 16: 131-134.

Bareth C. 2002. Campodeidea de la Grotte Scaloria (Gargano, Italia), Diplura, Campodeidae. Bulletin de l'Académie lorraine des Sciences 41: 3-4.

Bareth C. 2006. Les Campodes de France (Diploures Campodéidés). Mémoires de Biospéologie, hors série: $2-108$.

Bareth C. \& Condé B. 1981. Nouveaux Campodéidés de grottes d'Espagne. Revue suisse de Zoologie 88 (3): 775-786. Available from https://biodiversitylibrary.org/page/41337807 [accessed 13 Nov. 2019].

Bareth C. \& Condé B. 1984. Nouveaux Plusiocampa cavernicoles d'Italie continentale (Diplura Campodeidae). Bollettino della Società entomologica italiana 116 (8-10): 132-147.

Bareth C. \& Condé B. 1996. Le complexe de Plusiocampa pouadensis (Denis) dans les grottes de la région pyrénéenne. Mémoires de Biospéologie 23: 127-131. 
Bareth C. \& Condé B. 2001. Campodéidés des grottes de Bulgarie (Insecta: Diplura). Mémoires de Bioespéologie 28: 9-27.

Bellés X. 1987. Fauna cavernícola i intersticial de la Península Ibèrica i les Illes Balears. Publicaciones CSIC, Madrid.

Bellés X. 1991. Survival, opportunism and convenience in the processes of cave colonization by terrestrial faunas. In: Ros J.D. \& Prat N. (eds) Homage to Ramon Margalef; or, Why there is such Pleasure in Studying Nature. Oecologia Aquatica 10: 325-335.

Beutel R.G., Yavoskaya M.I., Mashimo Y., Fukni M. \& Meusemann K. 2017. The phylogeny of Hexapoda (Arthropoda) and the evolution of megadiversity. Proceedings of the Arthropodan Embryological Society of Japan 51: 1-15.

Blesić B. 1992. Plusiocampa rudnica n. sp. (Campodeidae, Diplura) from Serbia. Bulletin du Muséum d'Histoire naturelle de Belgrade 47: 145-148.

Christian E. 1992. Verbreitung und Habitatpräferenz von Doppel- und Zangenschwänzen in der Großstadt Wien (Diplura: Campodeidae, Japygidae). Entomologia Generalis 17: 195-205.

Christian E. \& Bauer T. 2007. Food acquisition and processing in Central European Diplura (Hexapoda). In: Tajovský K., Schlaghamerský J. \& Pižl V. (eds) Contributions to Soil Zoology in Central Europe II: 15-18. Institute of Soil Biology, České Budějovice, Czech Republic.

Christian E., Graf W. \& Moog O. 1996. Plusiocampa caprai - ein "Höhlentier" in den Kärntner Zentralalpen. Carinthia II 186/106: 387-392.

Christiansen K.A. 1965. Behaviour and form in the evolution of cave Collembola. Evolution 19 (4): 529-537.

Christiansen K.A. 2012. Morphological adaptations. In: White W.D. \& Culver D.C. (eds) Encyclopedia of Caves, second edition: 517-528. Elsevier, Academic Press, Amsterdam.

Condé B. 1947a. Campodéidés nouveaux des grottes Balkaniques. Notes biospéologiques 1: 17-32.

Condé B. 1947b. Description préliminaire d'un campodéide cavernicole du Causse Comtal. Notes biospéologiques 1: 33-36.

Condé B. 1948a. Les Campodéidés cavernicoles du Jura. Bulletin de l'Association spéléologique de l'Est 1 (1): 1-6.

Condé B. 1948b. Contribution à la connaissance des campodéidés cavernicoles de France. Notes biospéologiques 2: 35-48.

Condé B. 1948c. Addition a la faune des campodéidés cavernicoles de France. Bulletin de la Société des Sciences de Nancy, new series 7 (2): 45-54.

Condé B. 1948d. Description d'un Plusiocampa cavernicole nouveau de l'Herzégovine. Notes biospéologiques 2: 49-51.

Condé B. 1949. Plusiocampa provincialis n. sp. cavernicole de Provence (Diploures Campodéidés). Bulletin de la Société linnéenne de Lyon (Oct. 1949): 166-169.

Condé B. 1950. Description d'un Campodéidé cavernicole de Lombardie. Doriana (Annali del Museo Civico di Storia Naturale “G. Doria”) 1 (3): 1-4.

Condé B. 1951. Campodéidés cavernicoles de Catalogne. Speleon 2: 51-62.

Condé B. 1952. Campodéidés cavernicoles d'Afrique septentrionale (note préliminaire). Notes biospéologiques 7: 61-67. 
Condé B. 1953a. Diagnoses de nouvelles Campodéidés Corses. Bulletin du Muséum d'histoire naturelle, $2^{\circ}$ série 25: 562-567.

Condé B. 1953b. Campodéidés de la grotte de San Giovanni (Sardaigne). Notes biospéologiques 8: 33-37.

Condé B. 1954a. Ordnung: Entotropha (Diplura). In: Franz H. (ed.) Der Nordost im Spiegel ihrer Landtierwelt: 644-649. Universitätsverlag Wagner, Innsbruck, Austria.

Condé B. 1954b. Campodéidés cavernicoles de la Péninsule Italienne (note préliminaire). Notes biospéologiques 9: 37-40.

Condé B. 1954c. Campodéidés cavernicoles d'Afrique septentrionale ( $2^{\mathrm{e}}$ note). Notes biospéologiques 9: 41-43.

Condé B. 1955a. Matériaux pour une monographie des Diploures Campodéidés. Mémoires du Muséum national d'histoire naturelle, série A, Zoologie 12: 1-202.

Condé B. 1955b. Campodéidés cavernicoles des Baléares. Notes biospéologiques 9: 121-132.

Condé B. 1955c. Mision Henri Coiffait au Liban (1951). 4. Protoures et Diploures Campodéidés. Biospeologica 75: 397-412.

Condé B. 1956a. Campodéidés cavernicoles de Grèce. Notes biospéologiques 11: 7-12.

Condé B. 1956b. Campodéidés des grottes de Sardaigne (Insecta Diplura). Atti VII Congresso Nazionale di Speologia, Memoria 3: 199-202.

Condé B. 1957. Un Diploure cavernicole inédit des Alpes de Provence. Notes biospéologiques 12: 7-12.

Condé B. 1959. Un singulier diploure cavernicole de Dalmatie. Fragmenta Balcanica 2 (20): 165-172.

Condé B. 1961. Stations et variation de Plusiocampa magdalenae Condé et de P. bonadonai Condé (Diploures Campodéidés). Annales de Spéléologie 16 (4): 387-399.

Condé B. 1962. Campodéidés des grottes de Sardaigne (Insecta Diplura). Atti VII Congresso nazionale di Speleologia, Memoria III: 199-202.

Condé B. 1966. Campodéidés de la région de Recoaro (Vénétie). Revue d'Ecologie et de Biologie du Sol 3 (1): 166-169.

Condé B. 1978. Diplopodes Pénicillates, Diploures Campodéidés et Palpigrades des îles Ponziane. Revue d'Écologie et de Biologie du Sol 15 (2): 273-277.

Condé B. 1981a. Description d'un Campodéidé énigmatique de Sardaigne (Insecta: Diplura). Revue suisse de Zoologie 88 (1): 95-99. Available from https://biodiversitylibrary.org/page/41323335 [accessed 13 Nov. 2019].

Condé B. 1981b. Un nouveau Plusiocampa troglobie du massif de la Sainte-Baume (Diploures Campodéidés). Revue suisse de Zoologie 88 (3): 589-594.

Available from https://biodiversitylibrary.org/page/41337647 [accessed 13 Nov. 2019].

Condé B. 1982. Un extraordinaire Campodéidé troglobie des Picos de Europa (Santander), Espagne. Revue suisse de Zoologie 89 (1): 69-76. Available from https://biodiversitylibrary.org/page/41323919 [accessed 13 Nov. 2019].

Condé B. 1983. Le genre Plusiocampa dans les grottes sardes (Diploures Campodéidés). Revue suisse de Zoologie 90 (4): 899-905. Available from https://biodiversitylibrary.org/page/41311753 [accessed 13 Nov. 2019]. 
Condé B. 1984a. Diploures Campodéidés (Insectes) de Grèce (1 $1^{\text {ère }}$ note). Revue suisse de Zoologie 91 (1): 173-201. Available from https://biodiversitylibrary.org/page/41303604 [accessed 13 Nov. 2019].

Condé B. 1984b. Découverte du genre Plusiocampa en Afrique Septentrionale. Mémoires de Biospéologie 9: 243-245.

Condé B. 1993a. Une lignée danubienne du genre Plusiocampa (Diploures Campodéidés). Revue suisse de Zoologie 100 (3): 735-745. Available from https://biodiversitylibrary.org/page/41223871 [accessed 13 Nov. 2019].

Condé B. 1993b. Premiers Campodeidae cavernicoles de Chine, comme exemple de l'évolution souterraine de la famille (Diplura). Revue suisse de Zoologie 100 (4): 823-828.

Available from https://biodiversitylibrary.org/page/41223963 [accessed 13 Nov. 2019].

Condé B. 1996. Diploures Campodéidés de la Peştera de la Movile (Movile Cave), Dobroudja méridionales (Roumanie). Revue suisse de Zoologie 103 (1): 101-114.

Available from https://biodiversitylibrary.org/page/41267657 [accessed 13 Nov. 2019].

Condé B. 1997. Premieres Diploures Campodéidés de grottes du Brésil (Insecta: Diplura). Mémoires de Biospéologie 24: 43-47.

Condé B. \& Bareth C. 1996. Une évaluation de Stygiocampa, sous-genre troglomorphe du Plusiocampa (Diplura Campodeidae), avec la description d'une nouvelle espèce de Serbie orientale. Revue suisse de Zoologie 103 (2): 369-381. Available from https://biodiversitylibrary.org/page/41267935 [accessed 13 Nov. 2019].

Condé B. \& Mathieu A. 1957. Campodéidés endogés de la Région Pyrénéenne. Vie et Milieu 8 (4): $439-472$.

Condé B. \& Poivre C. 1982. Plusiocampa bonadonai Condé au Valais (Insecta, Diplura). Revue suisse de Zoologie 89 (1): 167-176. Available from https://biodiversitylibrary.org/page/41324017 [accessed 13 Nov. 2019].

Condé B. \& Sendra A. 1989. Description du premier Campodéidé cavernicole du sud de la péninsule Ibérique (Diplura, Campodeidae). Revue suisse de Zoologie 96 (3): 611-617.

Available from https://biodiversitylibrary.org/page/41306046 [accessed 13 Nov. 2019].

Culver D.C. 1982. Cave Life. Harvard University Press, Cambridge, MA.

Culver D.C., Deharveng L., Bedos A., Lewis J.J., Madden M., Redell J.R., Sket B., Trontelj P. \& White D. 2006. The mid-latitude biodiversity ridge in terrestrial cave fauna. Ecography 29: 120-128.

https://doi.org/10.1111/j.2005.0906-7590.04435.x

Dallwitz M. 2005. Applications and Documentation of the DELTA System.

Available from http://deltaintkey.com [accessed 12 May 2019].

Decourt J., Gaetani M., Vrielynck B., Barrier E., Biju-Duval B., Brunet M.F., Cadet J.P., Crasquin S. \& Sandulescu M. (eds) 2000. Atlas of Peri-Tethys Palaeogeographical Maps. CCGM, Paris.

Denis J.R. 1923. Notes sur les Aptérygotes. Ordre: Diplura C.B. Annales de la Société entomologique de France 92: 231-236.

Denis J.R. 1930. Sur la faune française des Aptérygotes, XI note: Diploures avec tableau de détermination des espèces françaises. Bulletin de la Société zoologique de France 55: 19-41.

Denis J.R. 1949. Ordre des Diploures. In: Grassé P.P. (ed.) Traité de Zoologie 9: 160-185. Masson, Paris. 
Donat K. 1975. Die Höhlenfauna der Schwäbischen Alb mit Einschlu $\beta$ des Dinkelberges, des Schwarzberges und des Wutachgebietes. Versuch einer Monographie. Jahreshefte des Vereins für väterländische Naturkunde in Württemberg 130: 260-381.

Giachino P.M. \& Vailati D. 2010. The Subterranean Environment. Hypogean Life, Concepts and Collecting Techniques. WBA Handbooks, Volume 3. World Biodiversity Association, Verona, Italy.

Giachino P.M., Decu V. \& Juberthie C. 1998. Coleoptera Cholevidae. In: Juberthie C. \& Decu V. (eds) Encyclopaedia Biospeologica: 1083-1122. Fabbro, Saint-Girons, France.

Gunn A. 1992. The ecology of Campodea lankestri (Silvestri) (Diplura). The Entomologist 111 (4): 201-209.

Hamann O. 1896. Europäische Höhlenfauna, mit besonderer Berücksichtigung der Höhlenfauna Karins. H. Costenoble, Jena, Germany.

Hüppop K. 2000. How do cave animals cope with the food scarcity in caves? In: Wilkens H., Culver D.C. \& Humphreys W.F. (eds) Ecosystems of the World: 30 Subterranean Ecosystems: 159-188. Elsevier, Amsterdam.

Ionescu M.A. 1951. Contributiuni la studiul Campodeidelor din Republica Populara Romana. Buletin Ştiinţific, Secţiunea de Ştiinţe Biologice, Agronomice, Geologice si Geografice III (3): 525-532.

Ionescu M.A. 1955. Diplura. In: Academia Republicii Socialiste România (ed.) Fauna Republicii Populare Române, Insecta 7 (2): 1-48.

Jiménez-Valverde A., Sendra A., Garay P. \& Reboleira A.S.P.S. 2017. Energy and speleogenesis: Key determinants of terrestrial species richness in caves. Ecology and Evolution 7 (23): 10207-10215. https://doi.org/10.1002/ece3.3558

Joseph G. 1882. Systematisches Verzeichniss der in den Tropfstein-Grotten von Krain einheimischen Arthropoden nebst Diagnosen der vom Verfasser entdeckten und bisher noch nicht beschriebenen Arten. Berliner entomologische Zeitschrift 26: 24-31.

Juberthie C. \& Decu V. 1994. Structure et diversité du domaine souterrain; particularités des habitats et adaptations des espèces. In: Juberthie C. \& Decu V. (eds) Encyclopaedia Biospeologica 1: 5-22. Société de Biospéologie, Moulis and Bucharest.

Juberthie-Jupeau L. \& Bareth C. 1980. Ultrastructure des sensilles de l'organe cupuliforme de l'antenne des Campodes (Insecta: Diplura). International Journal of Insect Morphology and Embryology 9: 255268.

Loksa I. 1960. Faunistisch-systematische und ökologische Untersuchungen in der Lóczy-Höhle bei Balatonfüred (Biospeologica Hungarica XL). Annales Universitatis Scientiarum Budapestinensis, Sectio Biologica 3: 253-266.

Moldovan O.T. 2008. Why so many Leptodirini (Coleoptera, Leiodidae) in Romania? Advances in arachnology and developmental biology. In: Makarov S.E. \& Dimitrijević R.N. (eds) Papers Dedicated to Prof. Dr. Božidar Ćurčić: 473-483. University of Belgrade, Belgrade.

Moldovan O.T. \& Rajka G. 2007. Historical biogeography of subterranean beetles - between "Plato's cave" or scientific evidence? Acta Carsologica 36 (1): 77-86.

Moldovan O.T., Kováč L. \& Halse S. 2018. Preamble. In: Moldovan O.T., Kováč L. \& Halse S. (eds) Cave Ecology: 1-4. Springer, Basel.

Moniez R. 1894. Espèces nouvelles de thysanoures trouvées dan la grotte de Dargilan. Revue biologique du Nord de la France 6: 81-86. Available from https://biodiversitylibrary.org/page/10877325 [accessed 2 Jan. 2020]. 
Neuherz H. 1984. Torocampa hölzeli n. gen., n. spec. - eine klasobionte Campodeide (Diplura, Apterygota) aus der Hafnerhöhle in den Karawanken, Kärnten. Carinthia II 174/94: 415-427.

Orelli M. 1956. Untersuchungen zur postembryonalen Entwicklung von Campodea (Insecta, Apterygota). Verhandlungen der naturforschenden Gesellschaft in Basel 67 (3): 501-574.

Ortuño V.M., Gilgado J.D., Jiménez-Valverde A., Sendra A., Pérez-Suárez G. \& Herrero-Borgoñón J.J. 2013. The "Alluvial Mesovoid Shallow Substratum", a new subterranean habitat. PLoS One 8 (10): e76311. https://doi.org/10.1371/journal.pone.0076311

Pagés J. 1959. Remarques sur la classification des diploures. Travaux du Laboratoire de Zoologie et de la Station aquicole Grimaldi de la Faculté des Sciences de Dijon 26: 1-25.

Paclt J. 1957. Diplura. In: Wytsman P. (ed.) Genera Insectorum 212: 1-123. L. Desmet-Verteneuil, Brussels.

Paclt J. 1979. Neue Beiträge zur Kenntnis der Apterygoten-Sammlung des zoologischen Instituts und zoologischen Museums der Universität Hamburg: VI. Entomologische Mitteilungen aus dem zoologischen Museum Hamburg 6 (105): 221-228.

Racovitză E.G. 1907. Essai sur les problèmes biospéologiques. Archives de Zoologie expérimentale et générale 6: 371-488.

Ramellini P. 1990. I Diplura dei Monti Ausoni e Aurunci (Lazio): fauna ed ecologia. Bollettino dell'Associazione romana di Entomologia 44: 13-28.

Reboleira A.S.P.S., Sendra A., Gonçalves F. \& Oromí P. 2010. The first hypogean dipluran from Portugal: description of a new species of the genus Litocampa (Diplura: Campodeidae). Zootaxa 2728: 50-56. https://doi.org/10.11646/zootaxa.2728.1.4

Rögl F. \& Steininger F.F. 1984. Neogene Paratethys, Mediterranean, and Indo-Pacific seaways. Implications for the paleobiogeography of marine and terrestrial biotas. In: Brenchley P. (ed.) Fossils and Climate: 171-200. John Wiley and Sons Ltd, Hoboken, NJ.

Rosenbaum G., Lister G.S. \& Duboz C. 2002. Reconstruction of the tectonic evolution of the Western Mediterranean since the Oligocene. In: Rosenbaum G. \& Lister G.S. (eds) Reconstruction of the Evolution of the Alpine-Himalayan Orogen. Journal of the Virtual Explorer 8: 107-130.

Rusek J. 1965. Zur Kenntnis der Campodeidae (Diplura) Bulgariens. Acta Entomologica Bohemoslavaca 62: 92-97.

Santanach P., Banda E., Calvet F., Carreras J., Casas J.M., Fontboté J.M., Fornós J., Gisbert J., Julivert M., Marzo M., Rodríguez A., Salas R. \& Souquet P. 1986. Geologia (I). Història natural dels Països catalans. In: Enciclopèdia Catalana SA (ed.) Enciclopèdia Catalana. Grup Enciclopèdia, Barcelona.

Schettino A. \& Turco E. 2006. Plate kinematics of the Western Mediterranean region during the Oligocene and Early Miocene. Geophysical Journal International 166: 1398-1423.

Sendra A. 1985. Campodéidos (Insecta: Diplura) cavernícolas de Cataluña y Huesca. I. Géneros Plusiocampa Silv., Litocampa Silv. y Podocampa Silv. Butlletí Institució Catalana d'Història Natural 52 (Zoologia 6): 119-128.

Sendra A. 1988. Taxonomía, Filogenia y Biogeografia de la Fauna de Campodeidos Ibérica, Balear y Canaria (Hexapoda, Diplura, Campodeidae). PhD thesis. Universitat de València.

Sendra A. 2001. Dipluros campodeidos (Diplura: Campodeidae) de las grutas almerienses (Almería, España). Zoologica Baetica 12: 71-82. 
Sendra A. 2003. Distribución y colonización de los Campodeidos cavernícolas en la Peninsula Ibérica e Islas Baleares. Boletín de la Sociedad española de Espeleología y Ciencias del Karst 4: 12-20.

Sendra A. 2015. Orden Diplura. Revista Ibero Diversidad Entomológica@ccesible-SEA 35: 1-11.

Sendra A. \& Condé B. 1986. Une nouvelle espèce de Plusiocampa des grottes d'Alicante, Espagne (Insecta, Diplura). Revue suisse de Zoologie 93 (4): 971-978.

Available from https://biodiversitylibrary.org/page/41154152 [accessed 13 Nov. 2019].

Sendra A. \& Condé B. 1987. Plusiocampa lagari, nouvelle espèce troglobie du sud-est de l'Espagne (Insecta, Diplura). Revue suisse de Zoologie 94 (4): 741-748.

Available from https://biodiversitylibrary.org/page/41153598 [accessed 13 Nov. 2019].

Sendra A. \& Condé B. 1988. Une nouvelle espèce d'Oncinocampa Condé de grottes des Montes Cantábricos de Santander, Espagne (Insecta, Diplura). Revue suisse de Zoologie 95 (4): 1019-1026. Available from https://biodiversitylibrary.org/page/41313641 [accessed 13 Nov. 2019].

Sendra A. \& Escolà O. 2004. Campodéidés cavernicoles du nord-est de la péninsule Ibérique. Revue suisse de Zoologie 111 (4): 889-914. Available from https://biodiversitylibrary.org/page/41227849 [accessed 13 Nov. 2019].

Sendra A. \& Reboleira A.S.P.S. 2014. La extensión y los límites de la fauna en los hábitats subterráneos. Boletín de la Asociación Española de Entomología 38 (3-4): 203-224.

Sendra A. \& Weber D. 2018. An unexpected discovery of a new subgenus and a species of Plusiocampa (Campodeidae, Diplura) alongside an overview of Central European subterranean campodeids. European Journal of Taxonomy 428: 1-21. https://doi.org/10.5852/ejt.2018.428

Sendra A. \& Wagnell C. 2019. The cave-dwelling dipluran (Diplura, Campodeidae) on the edge of the Last Glacial Maximum in Vancouver Island caves, North America (Canada). Subterranean Biology 29: 59-77. https://doi.org/10.3897/subtbiol.29.31467

Sendra A., Lara M.D., Ruiz Aviles F. \& Tinaut A. 2004. Une nouvelle espèce du genre Plusiocampa Silvestri, 1912 (Diplura, Campodeidae) et données pour sa reconstruction paléobiogéographique dans les Bétiques. Subterranean Biology 2: 113-122.

Sendra A., Satar A. \& Montagud S. 2006. Première contribution à la faune de Diploures Campodéidés de la Péninsule d'Anatolie, Turquie (Diplura: Campodeidae). Revue suisse de Zoologie 113 (3): 693709. Available from https://biodiversitylibrary.org/page/41228213 [accessed 13 Nov. 2019].

Sendra A., Teruel S., Satar A., Tusun S. \& Özbay C. 2010. New species, new records, and distribution of Campodeidae (Diplura) in Anatolia. Zootaxa 2639: 40-52. https://doi.org/10.11646/zootaxa.2639.1.4

Sendra A., Arnedo M.A., Ribera C., Teruel S., Bidegaray-Batista L. \& Condé B. 2012a. Revision of Cestocampa Condé (Diplura, Campodeidae), with description of a new species from caves in the eastern Iberian Peninsula. Zootaxa 3252: 43-56. https://doi.org/10.11646/zootaxa.3252.1.2

Sendra A., Nitzu E. \& Sanjuan A. 2012b. Half a century after Ionescu's work on Romanian Diplura A faunal contribution based on material collected from karst areas. Travaux de l'Institut de Spéologie "Émile Racovitzã " 51: 37-66.

Sendra A., Palacios J., Garcia A. \& Montejo M. 2016. New species of Campodeidae (Diplura) from Mexican caves. Zootaxa 4072 (5): 540-558. https://doi.org/10.11646/zootaxa.4072.5.2

Sendra A., Sket B. \& Stoev P. 2017a. A striking new genus and species of troglobitic Campodeidae (Diplura) from Central Asia. Subterranean Biology 23: 47-68. https://doi.org/10.3897/subtbiol.23.14631 
SENDRA A. et al., Euro-Mediterranean Plusiocampinae and tachycampoid diplurans

Sendra A., Jiménez-Valverde A., Gilgado J.D., Ledesma E., Baquero E., Pérez-Suárez G., Cuesta E., Herrero-Borgoñón J.J., Jordana R., Tinaut A., Barranco P. \& Ortuño V.M. 2017b. Diplurans of subsurface terrestrial habitats in the Iberian Peninsula, with a new species description (Diplura: Campodeidae). Zootaxa 4291 (1): 61-80. https://doi.org/10.11646/zootaxa.4291.1.4

Sendra A., Jiménez-Valverde A., Rochat J., Legros V., Gasnier S. \& Cazanove G. 2017c. A new and remarkable troglobitic Lepidocampa Oudemans, 1890 species from La Réunion Island, with a discussion on troglobiomorphic adaptations in campodeids (Diplura). Zoologischer Anzeiger 266: 95-104.

Sendra A., Yoshizawa K. \& Ferreira R.L. 2018. New oversize troglobitic species of Campodeidae in Japan (Diplura). Subterranean Biology 27: 53-73. https://doi.org/10.3897/subtbiol.27.28575

Sendra A., Nicolosi G. \& Amore E. 2019. Subterranean Campodeidae fauna from Sicily Island (Diplura); its biogeographical interest with the description of a new species of Plusiocampa. Zootaxa 4567 (2): 379-386. https//doi.org/10.11646/zootaxa.4567.2.10

Silvestri F. 1912. Contribuzione alla conoscenza dei Campodeidae (Thysanura) d'Europa. Bolletino del Laboratorio di Zoologia generale e agraria in Portici 6: 110-147.

Silvestri F. 1931a. Campodeidae (Insecta Thysanura) dell'estremo Oriente. Bolletino del Laboratorio d'Entomologia agraria in Portici 25: 286-320.

Silvestri F. 1931b. Contributo alla conoscenza dei Campodeidae (Thysanura) della grotte della Bulgaria. Bulletin des Institutions royales d'Histoire naturelle à Sofia 6: 97-107.

Silvestri F. 1932. Campodeidae (Thysanura) de España (primera parte). Eos 8: 115-164.

Silvestri F. 1933a. Nuovi contributi alla conoscenza della fauna delle isole italiane dell'Egeo. Bolletino del Laboratorio di Zoologia generale e agraria in Portici 27: 61-111.

Silvestri F. 1933b. Descrizione di una nuova specie cavernicola di Campodeidae (Thysanura Entothropha) del Trentino. Bollettino del Laboratorio di Entomologia agraria de Bologna 6: 1-4.

Silvestri F. 1933c. Beschreibung einer neuen cavernicolen Plusiocampa-Art (Campodeidae). Mitteilungen über Höhlen- und Karstforschung 3: 30-33.

Silvestri F. 1934. Tisanuri cavernicola della regione di Postumia. Atti del I Congresso Speologico Nazionale: 179-181. Trieste.

Silvestri F. 1936. Una nuova specie di Campodeidae (Dicillura) rappresentante di un nuovo genere, di grotta del Marrocco. Bulletin de la Société des Sciences naturelles du Maroc 16: 86-89.

Silvestri F. 1947. Illustrazione della Plusiocampa (Stygiocampa) nivea Joseph (Campodeidae, Diplura) della grotte di Postumia. Bolletino del Laboratorio d'Entomologia agraria in Portici 8: 88-92.

Silvestri F. 1949. Descrizione di due specie nuove cavernícole di Campodeidae (Insecta Diplura) della regione del Monte Tauro. Bolletino del Laboratorio d'Entomologia agraria in Portici 9: 27-31.

Stach J. 1930. Verzeichnis der Apterygogenea Ungarns. Annales Musei Nationalis Hungarici 26: 269312.

Strouhal H. \& Vornatscher J. 1975. Katalog der rezenten Höhlentiere Österreichs. Annalen des naturhistorischen Museums in Wien 79: 401-542.

Viré M.A. 1897. Le Campodea staphylinus Westwood, et ses variétés cavernicoles (C. cookei Packard; C. dargilani Moniez; C. nivea Joseph; C. erebophila Amann). Bulletin du Muséum national d'histoire naturelle 3: 89-95. 
Vornatscher J. 1943. Zur Verbreitung von Plusiocampa strouhali Silv. Zeitschrift für Karst- und Höhlenkunde 1942-1943: 174-178.

Wygodzinsky P. 1944. Contribuição ao conhecimento da familia Campodeidae (Entotrophi, Insecta) do Mexico. Annales de la Escuela nacional de Ciencias biológicas 3: 367-404.

Manuscript received: 17 May 2019

Manuscript accepted: 18 September 2019

Published on: 10 January 2020

Topic editor: Gavin Broad

Desk editor: Danny Eibye-Jacobsen

Printed versions of all papers are also deposited in the libraries of the institutes that are members of the EJT consortium: Muséum national d'histoire naturelle, Paris, France; Meise Botanic Garden, Belgium; Royal Museum for Central Africa, Tervuren, Belgium; Royal Belgian Institute of Natural Sciences, Brussels, Belgium; Natural History Museum of Denmark, Copenhagen, Denmark; Naturalis Biodiversity Center, Leiden, the Netherlands; Museo Nacional de Ciencias Naturales-CSIC, Madrid, Spain; Real Jardín Botánico de Madrid CSIC, Spain; Zoological Research Museum Alexander Koenig, Bonn, Germany; National Museum, Prague, Czech Republic. 